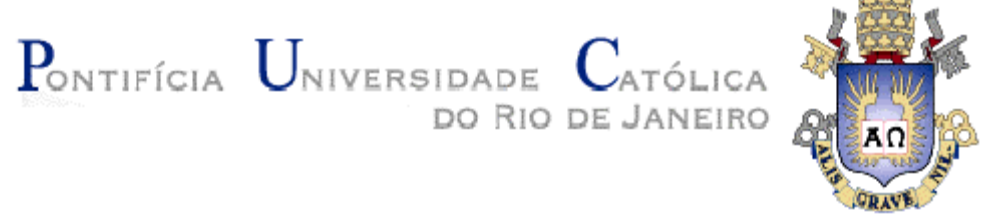

Maria Cordeiro de Farias Gouveia Matos

Ler e escrever nas aulas de Ciências: potencialidades e limites

\begin{abstract}
Tese de Doutorado
Tese apresentada como requisito parcial para a obtenção do grau de Doutora em Ciências Humanas/Educação pelo Programa de PósGraduação em Educação do Departamento de Educação da PUC-Rio.
\end{abstract}

Orientador: Profª Zena Eisenberg

Volume I

Rio de Janeiro

Abril de 2018 


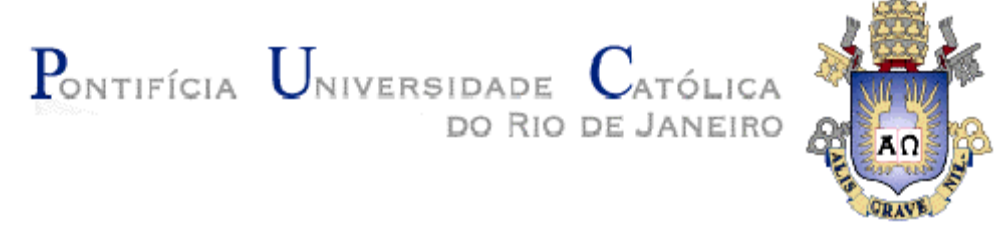

Maria Cordeiro de Farias Gouveia Matos

\title{
Ler e escrever nas aulas de Ciências: potencialidades e limites
}

Tese apresentada como requisito parcial para obtenção do grau de Doutor pelo Programa de Pós-graduação em Educação da PUC-Rio. Aprovada pela Comissão Examinadora abaixo assinada.

\author{
Prof ${ }^{\mathrm{a}}$ Zena Winona Eisenberg \\ Orientadora \\ Departamento de Educação PUC-Rio \\ Prof ${ }^{a}$ Maria Margarida Pereira de Lima Gomes \\ Universidade Federal do Rio de Janeiro \\ Prof ${ }^{\mathrm{a}}$ Tatiana Galieta Nascimento \\ Universidade do Estado do Rio de Janeiro \\ Prof ${ }^{\mathrm{a}}$ Erica dos Santos Rodrigues \\ Puc-Rio \\ Prof Pedro Pinheiro Teixeira \\ Departamento de Educação PUC-Rio \\ Profa. Monah Winograd \\ Coordenadora Setorial do Centro de Teologia \\ e Ciências Humanas - PUC-Rio
}

Rio de Janeiro, 27 de abril de 2018. 
Todos os direitos reservados. É proibida a reprodução total ou parcial do trabalho sem autorização da universidade, da autora e do orientador.

\section{Maria Cordeiro de Farias Gouveia Matos}

Graduou-se como bacharel e licenciada em Ciências Biológicas na UFRJ. Finalizou o mestrado em Educação pela FE/ UFRJ em 2009, no qual desenvolveu uma pesquisa sobre o campo da educação ambiental. De 2104 a 2018 cursou o doutorado em Educação e Ciências Humanas na PUC-Rio. Trabalha como docente da escola básica desde 2006. Em 2011 se tornou professora efetiva do Colégio de Aplicação da UFRJ, no qual atua na educação básica como professora de Ciências e Biologia, na orientação de estágio supervisionado na formação inicial docente e em cursos de especialização para formação continuada de professores.

Ficha Catalográfica

Matos, Maria Cordeiro de Farias Gouveia

Ler e escrever nas aulas de Ciências: potencialidades e limites / Maria Cordeiro de Farias Gouveia Matos ; orientadora: Zena Eisenberg. 2018.

2v. : il. color. ; $30 \mathrm{~cm}$

Tese (doutorado)-Pontifícia Universidade Católica do Rio de Janeiro, Departamento de Educação, 2018.

Inclui bibliografia

1. Educação - Teses. 2. Leitura. 3. Escrita. 4. Ensino de Ciências. I. Eisenberg, Zena. II. Pontifícia Universidade Católica do Rio de Janeiro. Departamento de Educação. III. Título. 
Para minha filha Mel Lyra, com todo meu amor. Por me mostrar e me desafiar, cotidianamente, a imaginar um mundo diferente.

Em memória da minha querida prima Juliana Cordeiro de Farias Bosslet, pelo seu sorriso brilhante, por tudo de bonito que nos deixou e porque sei que estaria comigo comemorando essa conquista. Saudades.

$\grave{A}$ s professoras e professores que cotidianamente constroem o ensino de Ciências do nosso país e lutam por uma educação pública e democrática, apesar de todas as adversidades. 


\section{Agradecimentos}

À minha querida professora e orientadora Zena Eisenberg por ter me aceitado como orientanda, ter acreditado nas minhas questões e ter sempre me apoiado. Pelos ensinamentos, por ter me ajudado a crescer como pesquisadora, como professora e como pessoa. Por ter respeitado minhas ausências meio atrapalhadas e por ter sempre acreditado em mim. Agradeço todo afeto e generosidade na troca de conhecimentos.

Aos professores e professoras do PPGE PUC-Rio pelos conhecimentos e questionamentos repartidos e pelos ensinamentos. As leituras e discussões construídas fazem parte profundamente dessa tese. Agradeço, especialmente, ao querido professor Marcelo Andrade, que muito nos ensinou sobre respeito e ética e deixa tantas saudades. Obrigada por terem sido sempre respeitosos e compreensivos com as questões de saúde que enfrentei nesse período. Os conhecimentos compartilhados me permitiram focar em outros aspectos da vida, me mantendo forte para me recuperar.

Às funcionárias e funcionários do Departamento de Educação da PUC Rio, pelo respeito e dedicação na relação com os/as docentes e os/as alunos/as.

À PUC-Rio e ao CNPq pelo apoio financeiro.

Aos amigos e amigas da minha turma de doutorado em educação, a "coorte 2014". Por me apoiarem, me darem força todo tempo, me ajudarem a superar as dificuldades, terem sido sempre muito solidários e generosos com as questões de saúde que enfrentei e terem me ensinado tanto nas reflexões compartilhadas. Vocês me ajudaram a entender que a academia pode ser construída com cooperação e afeto.

Às companheiras e companheiros do grupo de pesquisa GruDHE pelas discussões, pelas reflexões, pelas sugestões para pesquisa. Por terem me questionado e me feito pensar nos caminhos que eu estava seguindo na investigação e nas análises. Por terem trocado tantos conhecimentos sobre educação. Agradeço especialmente à amiga Juliana Jandre, que me ajudou a fazer o abstract deste trabalho, e à amiga Cátia Papadopoulos pela revisão cuidadosa e criteriosa do capítulo de resultados. Também à Clara e à Mayara, que colaboraram no teste da validade dos códigos, e à Ana Carolina Pereira pela ajuda incansável nas transcrições das entrevistas e das gravações de áudio das aulas.

À professora Maria Margarida Gomes, por ter participado tão intensamente da minha formação como professora, como pessoa e agora também como pesquisadora. Agradeço pelas contribuições e reflexões nas qualificações e por aceitar compor a banca avaliativa deste trabalho.

À professora Érica dos Santos Rodrigues pelas valiosas trocas e contribuições na disciplina de estudos individuais e por aceitar fazer parte da banca. Aos demais professores e professoras da banca Tatiana Galieta, Pedro Teixeira, Laura Stobäus 
e Simone Salomão. É muito importante poder contar com as suas avaliações para o enriquecimento deste trabalho.

À professora Cecília Goulart por ter me iniciado nos estudos bakhtinianos. Pelos diálogos sobre Bakhtin, pela troca e generosidade. Aprendi demais na participação como ouvinte de sua disciplina na UFF.

Às professoras de Ciências que abriram as portas de suas salas de aula para que eu realizasse esta pesquisa. A escolha de exporem suas atividades, seus diálogos com os alunos, suas reflexões e questionamentos é muito corajosa e mostra um entendimento de educação e pesquisa generoso, de quem acredita na produção e na troca de conhecimentos. Não tenho palavras para agradecer. Aprendi imensamente com vocês. Estendo esse agradecimento também aos alunos e alunas das turmas observadas, pois aguentaram firme minha presença e se dispuseram a colaborar com a investigação.

Aos meus colegas professores e professoras e aos funcionários e funcionárias do Colégio de Aplicação da UFRJ por terem concedido a licença de estudos para que eu realizasse o campo empírico dessa pesquisa. Por compreenderem minhas ausências e terem sempre apoiado o investimento na minha formação. Agradeço especialmente as minhas amigas do Setor Curricular de Biologia Carla Maciel, Isabel Lima, Natália Rios e Celina Costa e ao amigo Filipe Porto. Por terem segurado a onda com a escola e suas múltiplas demandas para que eu pudesse cursar o doutorado. Por serem tão amigos e me permitirem ter um cotidiano no trabalho recheado de afeto, reflexões e admiração. Agradeço também aos professores e professoras que compuseram a equipe durante o período do meu doutoramento e me ensinaram tanto.

Aos meus alunos e alunas da educação básica por cotidianamente me fazerem viver o encantamento da descoberta. Aos licenciandos e licenciandas que me ajudam a refletir sobre a escola e a educação.

Aos amigos e amigas da Biologia que ao longo de todos esses anos vêm compartilhando comigo a ilusão de que podemos transformar o mundo. Vocês me constituem. Luiza, Cris, Letícia, Gabriel, Titi, Juliana, Maksin, Gabi, Tatá, Maíra, Isabel, Marcão, Dudu, Luiza São Thiago, Ká, Aninha, entre tantos outros. Aos amigos e amigas do ORT (ou DUARTE) e aos amigos da vida que estiveram perto nesse processo e me apoiaram sempre, Flavinha, Paulinha, Coral, Bruno, Fê, Lessa e Pedro, Niuxa e Neilton, Mariana Vilela e Jacqueline Girão. Nem tenho como nomear todos e todas. $\mathrm{O}$ apoio, o acolhimento e as risadas foram fundamentais. Obrigado por compreenderem minha distância e por mostrarem a todo tempo que estavam perto de mim.

Agradeço a minha família de lá, os Gouveias, por mesmo distantes, me apoiarem sempre. À minha família de cá, os Domingueiros, meus tios, minhas tias, meus primos, minhas primas, pelas conversas, pelo carinho, pelo apoio, pelas reflexões. Nem sei o que seria de mim sem vocês. Agradeço principalmente à minha avó Ignez pelo exemplo, dedicação, força e principalmente pelo amor incondicional. Aos meus irmãos Pedro e Thiago e aos meus sobrinhos Manuela, Theo e Aurora, por tanta alegria! Espero que agora a gente tenha mais tempo para brincar. 
Aos meus pais João e Florence. Por toda a vida. Pelo incentivo para os estudos e tudo o mais que tive vontade. Por estarem sempre perto. Por tanta dedicação e por tanto amor. Por me apoiarem em todos os momentos, sob qualquer circunstância. Por serem meu porto seguro. Por me ensinarem a pensar, a questionar e a lutar por um mundo mais justo. Amo vocês demais.

Ao meu companheiro Adilson. Por sempre acreditar em mim. Por dividir comigo tantos sonhos. Pelo cotidiano compartilhado. Por compreender as ausências, os mau-humores, as angústias e inquietações do processo da pesquisa. Por ter me dado colo nos momentos de choro. Por me fazer crescer e refletir profundamente sobre o nosso país. Pelas risadas, brincadeiras e passeios por aí, que ajudam a tornar a vida mais leve e mais gostosa. Te admiro muito.

Por fim, à minha filha Mel. Que aguentou como pôde meu distanciamento e me apoiou sempre. Por simplesmente ser ela, me iluminar e me fazer perceber a intensidade e a profundidade do amor. 


\section{Resumo}

Matos, Maria Cordeiro de Farias Gouveia, Eisenberg, Zena Winona. Ler e escrever nas aulas de Ciências: potencialidades e limites. Rio de Janeiro, 2018. 326 p. Tese de Doutorado - Departamento de Educação, Pontifícia Universidade Católica do Rio de Janeiro.

O principal objetivo da pesquisa foi investigar relações entre atividades pedagógicas da disciplina escolar Ciências e processos de ensino-aprendizagem de leitura e de escrita. Considerando que a aquisição da linguagem escrita é um compromisso da educação escolar, especialmente em sociedades grafocêntricas atuais, o estudo procurou construir reflexões sobre possíveis contribuições do ensino de Ciências para formação de estudantes leitores e produtores de textos escritos. A investigação incluiu observações de aulas de Ciências de três diferentes professoras em três turmas de sexto ano do ensino fundamental de escolas da rede municipal do Rio de Janeiro. Foram também realizadas entrevistas semiestruturadas com as professoras e grupos de alunos das turmas, e análise dos materiais utilizados nas aulas. Os referenciais teórico-metodológicos baseiam-se em Bakhtin e trazem contribuições da perspectiva sociointeracionista da linguagem. A teoria sóciohistórica de Goodson colabora para a compreensão de características da disciplina escolar Ciências. Os resultados mostram que o espaço-tempo das aulas de Ciências é também um espaço-tempo para ler e escrever. O conhecimento escolar em Ciências é construído através da linguagem escrita, de forma que diferentes atividades envolvendo leitura e escrita acontecem nas aulas de Ciências. As professoras realizam a mediação da interação entre os estudantes e a linguagem escrita, influenciando seus processos de leitura e produção textual. Na mediação, elas atuam mobilizando estratégias e sistemas de conhecimento (linguístico, de mundo e interacional) necessários para que os estudantes leiam e escrevam, possibilitando a construção de sentidos para os textos. No diálogo em torno dos textos, gêneros primários e secundários do discurso aparecem, de maneira que as professoras trazem elementos cotidianos para a interação entre o texto e os alunos e, ao mesmo tempo, contribuem para a complexificação da linguagem, aproximando-a da forma escrita. Na cadeia discursiva da sala de aula, textos de variados gêneros aparecem e se associam às diferentes tradições curriculares da disciplina escolar Ciências. As professoras mesclam em suas falas diferentes concepções, que perpassam desde o entendimento da leitura e da escrita com foco 
na estrutura do texto até a compreensão destas atividades como uma interação social entre autor-texto-leitor. A centralidade da linguagem escrita nas aulas de Ciências e os conhecimentos e estratégias ativadas para que os estudantes interajam com textos escritos mostram o potencial da disciplina escolar Ciências para o ensinoaprendizagem da leitura e da escrita. Limites são estabelecidos pelas dificuldades relacionadas à formação docente e por questões estruturais, referentes ao controle do trabalho das professoras pelas avaliações externas e à falta de recursos. Esperase que a investigação possa contribuir com reflexões para o entendimento das aulas de Ciências como um espaço-tempo da linguagem escrita, importante para a formação de leitores e autores críticos e maduros, que possam se inserir em um mundo permeado por práticas sociais de leitura e escrita.

\section{Palavras-chave}

Leitura; escrita; ensino de Ciências. 


\section{Abstract}

Matos, Maria Cordeiro de Farias Gouveia, Eisenberg, Zena Winona (Advisor). Reading and writing in science classes: potentialities and limitations. Rio de Janeiro, 2018. 326 p. Tese de Doutorado Departamento de Educação, Pontifícia Universidade Católica do Rio de Janeiro.

The main objective of this research was to investigate the pedagogical activities in Science classes that are related to the development of reading and writing skills. Taking into account that the acquisition of written language is a commitment of school education commitment, especially in current graphocentric societies, the present study sought to reflect on possible contributions of Science classes to the development of readers and writers. Three sixth grade classrooms located in Rio de Janeiro were observed along with their science teachers. Semistructured interviews were conducted both with the teachers and students, and the didactic materials used by them were analyzed. The theoretical-methodological framework is based on Bakhtin and on the social interactionist perspective of language. Goodson's sociohistorical theory was used for understanding the characteristics of Science as a school discipline. Results show that Science class space-time is also space-time for reading and writing. Science knowledge is constructed in school through written language and, because of that, many different activities involving reading and writing take place in Science classes. The teachers mediate the interaction between the students and the written language, guiding their reading and textual production processes. Through mediation, they act in the mobilization of strategies and systems of knowledge (linguistic, world and interactional ones) that contribute to students' reading and writing skills, making the meaningful construction of texts possible. When talking about the texts, primary and secondary discourse genres appear, as the teachers bring everyday elements to the interaction between text and students and, at the same time, contribute to the complexity of language, bringing it closer to the written form. In the discursive chain of the classroom, texts of various genres are used and are associated with the different curricular traditions of Science as a school discipline. The teachers mix in their speech different conceptions of reading and writing: from one that focuses on the structure of the text to another that sees it as a social interaction among authortext-reader. The wide presence of written discourse and activities that deal with text 
interaction in Science classes show the potential of this school discipline for the development of reading and writing skills. Poor teacher education and infrastructure problems, such as influence of external evaluations and lack of resources, present obstacles to this type of work. It is expected that this research may contribute with reflections about the understanding of Science classes as a space-time for written language that is important for the education of critical and mature readers and authors, and who can then be inserted in a world permeated by social practices of reading and writing.

\section{Keywords}

Reading; writing; science education. 


\section{Sumário}

1 Introdução 14

1.1. Questões de pesquisa $\quad 26$

2 Referenciais teórico-metodológicos: a construção de um olhar para

$\begin{array}{ll}\text { a pesquisa } & 28\end{array}$

2.1. Linguagem 29

2.1.1. Enunciados e gêneros discursivos 30

2.1.2. Leitura e escrita 39

2.2. Disciplina escolar Ciências 49

2.2.1. Enfoque sócio-histórico da disciplina escolar Ciências 52

2.3. Diálogo com outras pesquisas 62

3 Estratégias metodológicas: a construção da empiria 73

3.1. Observação de aulas de ciências 75

3.1.1. Perfil das professoras, turmas e escolas selecionadas 79

3.1.2. Método de observação e análise dos dados 93

3.2. Análise de materiais didáticos 105

3.3. Entrevistas com professoras e estudantes 109

4 Leitura e escrita na disciplina escolar ciências 115

4.1. Professoras e estudantes: relações e sentidos sobre leitura e escrita nas aulas de Ciências

4.1.1. Concepções de leitura e escrita dos estudantes e das professoras

4.1.2. Dificuldades nos processos de ensino-aprendizagem de leitura e escrita

4.2. Dialogismo e a linguagem escrita nas aulas de Ciências 144

4.2.1.Mediação da leitura e da escrita nas aulas de Ciências 153

4.3. Atividades pedagógicas das aulas de Ciências e processos de leitura e de escrita

4.3.1. Cadernos Pedagógicos de Ciências e possibilidades de leitura e escrita 
Apêndice 1 - Termos de consentimento das professoras, responsáveis dos alunos e de assentimento dos alunos Apêndice 2 - Roteiro de entrevista das professoras 324 Apêndice 3 - Roteiro de entrevista dos estudantes 326 


\section{Introdução}

O presente texto compõe a minha tese de doutorado em educação. Nele construo um relato do caminho percorrido para o desenvolvimento da pesquisa. Esclareço as escolhas feitas e apresento reflexões para contribuir com o campo de pesquisa em educação e, especialmente, com os processos de ensino e aprendizagem escolar. Escrevo o texto do lugar de pesquisadora em educação, com todas as dificuldades e encantamentos que ele traz.

Apresento a tese ao final do quarto ano de doutoramento. Nos dois primeiros anos cursei variadas disciplinas acadêmicas que participaram da minha formação como pesquisadora em educação e para o estudo e aprofundamento da proposta de investigação, percebendo limites e potenciais da pesquisa que pretendia realizar. Conheci mais sobre o campo de pesquisa em educação e estudei teóricos de várias áreas, refletindo sobre perspectivas diferentes de entendimento e interpretação dos fenômenos educativos. A partir das reflexões e estudos realizados, desenvolvi a parte empírica da pesquisa no terceiro ano de doutoramento. Depois, ao longo de todo o último ano, trabalhei na construção e interpretação dos dados e no aprofundamento dos estudos dos referenciais teórico-metodológicos utilizados na pesquisa, articulando tais atividades com análises e a escrita desse texto. Tentei desenvolvê-lo da forma mais clara e transparente possível, para que servisse não só para troca de reflexões com pesquisadoras e pesquisadores da área, mas também com professoras e professores da escola, considerando que são elas e eles os sujeitos que constroem cotidianamente a educação básica do nosso país.

Em nossa pesquisa, investigamos relações entre atividades pedagógicas de aulas da disciplina escolar ciências e atividades de leitura e/ou escrita. Procuramos entender se o ensino de ciências pode contribuir com o aprimoramento da capacidade de leitura e de escrita de estudantes e de que forma essa contribuição pode se estabelecer. Nesse sentido, a investigação encontra-se no campo de pesquisa em educação, mais especificamente na interseção entre a pesquisa em ensino de Ciências e a pesquisa na área da linguagem, especialmente em relação à leitura e à escrita.

O objeto de pesquisa tem forte articulação com minha trajetória profissional e acadêmica. Marco o início do interesse por esse tema no estágio supervisionado 
docente realizado na minha formação inicial na licenciatura em Ciências Biológicas na Universidade Federal do Rio de Janeiro (UFRJ). Realizei o estágio docente em 2004 no Colégio de Aplicação da UFRJ (CAp/ UFRJ), acompanhando uma turma da quinta série do ensino fundamental (atualmente sexto ano) e uma do primeiro ano do ensino médio. A professora de ciências da quinta série, minha orientadora da prática de ensino na época (professora Dra. Maria Margarida Gomes), desenvolveu um projeto pedagógico com a turma com o objetivo de diversificar possibilidades de leitura dos estudantes denominado "Ciranda da Leitura de Ciências". Nesse período da escolaridade, primeiro ano do segundo segmento do ensino fundamental, frequentemente os ${ }^{1}$ alunos apresentam dificuldades com a cultura letrada; no ensino de ciências, isso aparecia como um grande obstáculo. Assim, já na prática de ensino, minhas primeiras reflexões sobre a articulação entre a linguagem escrita e o ensino de Ciências foram construídas.

Depois, na atuação como professora da rede estadual do Rio de Janeiro, novamente precisei lidar com as dificuldades de leitura e escrita dos alunos. Concomitantemente à minha atuação como professora do estado, eu trabalhava na rede particular, nos mesmos anos de escolaridade. A diferença entre as possibilidades de leitura e de escrita dos alunos, comparando essas duas realidades, me sensibilizava e me mostrava cotidianamente como a desigualdade estava marcada naquele aspecto e como o acesso ao conhecimento escolar era limitado por essa questão. Comecei então a estudar e trabalhar cada vez mais com atividades de leitura e de escrita com os estudantes, em diálogo com o conteúdo de Ciências. Ponderações sobre leitura e escrita eram centrais na minha atuação docente. Nesse contexto, participei de um projeto de extensão em parceria com o CAp/UFRJ e o "Projeto Fundão Biologia - UFRJ" " elaborando uma "Ciranda da Leitura" na escola

\footnotetext{
${ }^{1}$ Optamos por utilizar aqui e ao longo de todo o texto o generalizador masculino, como é o usual na língua portuguesa. Reconhecemos - a partir das discussões dos estudos de gênero - que ao fazer essa escolha estamos de certa forma nos submetendo ao caráter discriminatório de nossa língua. Mas, por uma questão de economia e clareza, e por entender que o uso de generalizador feminino chamaria atenção para questões muito importantes relacionadas à luta feminista, mas não tratadas diretamente na pesquisa, fizemos essa opção.

${ }^{2}$ O "Projeto Fundão Biologia - UFRJ" surgiu em 1983 com o objetivo de desenvolver atividades articuladas ao ensino e à pesquisa na educação em Ciências e Biologia, visando a melhoria do ensino público e a valorização do professor que atua na Educação Básica. Atualmente, é administrado pela equipe de Prática de Ensino em Ciências Biológicas da Faculdade de Educação da UFRJ. No projeto são desenvolvidos variados projetos de pesquisa, ensino e extensão, em permanente intercâmbio entre a universidade e diferentes escolas (http://www.projetofundao.ufrj.br/biologia/. Acesso em 01 de setembro de 2017).
} 
estadual na qual trabalhava, o Colégio Estadual Guilherme Briggs (MATOS et al, 2009).

Minha trajetória como professora e as reflexões desenvolvidas me levaram ao mestrado em educação e depois a me tornar professora efetiva do CAp/UFRJ. O Colégio de Aplicação hoje se caracteriza pela heterogeneidade social que o compõe. Fundado em 1948, a história dessa escola é marcada pela mudança na forma de ingresso dos alunos a partir de 1998, quando deixou de ser realizada por uma prova seletiva de admissão e passou a ocorrer por meio de um sorteio, o que democratizou o acesso à instituição ${ }^{3}$. Ao longo do tempo, tal modificação foi transformando o perfil socioeconômico da escola, que passou a ser mais heterogêneo, de forma que o corpo discente é hoje formado por estudantes oriundos de diversos locais da cidade do Rio de Janeiro, com variadas etnias, formações culturais e classes sociais. A diferença marca a escola e, nesse caso, vem acompanhada da desigualdade social, que se reflete nas possibilidades de acesso ao conhecimento formal ${ }^{4}$, inclusive de leitura e escrita. Recebemos alunos que chegam em anos avançados de escolaridade com dificuldades para interpretar e compreender pequenos textos e, principalmente, para desenvolver textos autorais. Tais dificuldades aparecem em quase todas as disciplinas escolares e carregam com elas o fracasso escolar, colocando em risco a própria permanência na escola. Diante dessa realidade, temos nos perguntado: como fazer para manter esses alunos na escola? Como incluí-los na construção do conhecimento acadêmico escolar? Percebo que isso passa, necessariamente, pelo trabalho com a leitura e a escrita. Lahire (2004), em suas pesquisas sobre Sociologia da Escrita, entende a escola como um espaço da cultura escrita, mais do que isso, uma cultura escrita própria e que se relaciona diretamente com o desempenho dos alunos. Assim, é preciso considerar a centralidade desses processos para o acesso ao conhecimento construído na escola. Nesse sentido, no trabalho como professora,

\footnotetext{
${ }^{3}$ É importante destacar, no entanto, que a realização do sorteio, apesar de mais democrático, não significou uma democratização total do processo de entrada na escola, pois o próprio acesso à informação de existência do Colégio de Aplicação, da possibilidade de inscrição para o sorteio e a escolha em participar desse processo depende do acesso a certo capital cultural, marcando a exclusão de determinados grupos sociais. Além disso, há a questão da localização da escola, que fica na Zona Sul do Rio de Janeiro, local de difícil acesso para grande parte da população.

${ }^{4}$ Denomino aqui conhecimento formal aquele mais acadêmico, normalmente descrito em livros e tradicionalmente valorizado pela escola. Reconheço que há muitas outras formas de conhecimento que estão além da leitura e da escrita, embora aqui eu esteja preocupada especificamente com aquele conhecimento que é construído através da leitura e da escrita.
} 
me coloco como parte de um projeto de formação de alunos leitores e escritores. Agora avanço para refletir sobre isso também como pesquisadora em educação.

Em minhas reflexões, penso não só na importância da interpretação e produção de textos escritos para a inclusão na cultura escolar, mas também na possibilidade de inserção e diálogo com tantos outros aspectos da sociedade que dependem da cultura letrada. As sociedades contemporâneas são grafocêntricas, isto é, a leitura e a escrita estão profundamente incorporadas à vida social, política, econômica e cultural. Nesse sentido, ser letrado nas sociedades atuais é necessário à vivência política, econômica e social, representa um bem simbólico, um bem cultural, uma instância privilegiada e valorizada de prestígio e poder (SOARES, 2007). Assim, acreditamos que se defendemos um projeto de escola capaz de se somar à luta por transformação social, de refletir e colaborar para a inclusão de grupos da sociedade historicamente excluídos de seus direitos sociais, civis e políticos, é papel dessa escola garantir o acesso ao mundo da leitura e da escrita.

Reflexões sobre a problemática da leitura e da escrita na educação e a relação destes aspectos com a exclusão social são também suscitadas ao analisarmos a questão da desigualdade educacional. O Brasil é um país marcado pela desigualdade. Nossos recursos econômicos, políticos e sociais são distribuídos de forma desigual entre as classes sociais, raças, gêneros, gerações, regiões e áreas de vida. As condições educacionais estão incluídas nesse reino da desigualdade e das condições precárias de sobrevivência. De acordo com Castro (2009), enfrentamos um grave problema de baixa escolaridade média da população, analfabetismo e desigualdade educacional no nosso país. $\mathrm{O}$ autor mostra que a média de anos de escolaridade da população de 15 anos ou mais apresentou um incremento nos últimos anos, mas continua muito pequena em comparação a outros países da América do Sul. A média de estudos no Brasil dessa população é de 7,3 anos, bem menor que os nove anos obrigatórios previstos na legislação. Além disso, essa média apresenta muitas variações, reflexo da desigualdade educacional. Os mais pobres apresentam uma média bem menor de anos de escolaridade que os mais ricos. Assim como os negros em comparação com os brancos e os moradores de área rural em relação aos de área urbana. Em pesquisa sobre o analfabetismo no Brasil, o autor comenta que o número de analfabetos girava em torno de 14 milhões 
de pessoas em $2009^{5}$ e carregava uma forte marca de desigualdade. Há um número bem maior de analfabetos no nordeste do Brasil, nas áreas rurais, entre os mais velhos (especialmente acima de 40 anos), a população negra e a de baixa renda.

Ferraro (2011) é outro autor que discute a questão da desigualdade educacional no Brasil, focando nas taxas de analfabetismo infantil. O estudo realizado expõe que as desigualdades educacionais quanto à alfabetização se constituem logo no início do processo de escolarização. Aos sete anos de idade as diferenças entre o percentual de crianças alfabetizadas em Alagoas (AL - estado com maior índice de analfabetismo infantil no Brasil) e no Rio Grande do Sul (RS - estado com menor índice de analfabetismo infantil no Brasil) já é de aproximadamente $44 \%$. Ou seja, $44 \%$ a mais de crianças aos sete anos no RS estão alfabetizadas em comparação com AL. As diferenças na taxa de alfabetização infantil são marcadas pelo gênero, raça e classe social. A taxa de alfabetização de brancos na infância é maior que a de negros, assim como a de mulheres em relação aos homens. Sendo que em todas as comparações, a classe é o fator mais determinante, os mais pobres são os que apresentam sempre menor taxa de alfabetização infantil. Com sete anos as desigualdades se constituem, aos oito anos se consolidam, e a partir de então marcam a trajetória escolar das crianças e jovens, que abandonam os estudos ou apresentam alto índice de reprovação, com variadas dificuldades de ensino-aprendizagem.

A desigualdade educacional reforça a crise atual da instituição escolar. Entre tantas questões que vêm sendo colocadas para se pensar a relação entre a escola e o mundo social, a leitura e a escrita se constituem elementos importantes. É preciso considerar de que forma a cultura escrita escolar se relaciona com o contexto social, cultural e político dos alunos nos diferentes espaços-tempo escolares, incluindo as aulas de Ciências. Argumentamos que o ensino de Ciências pode se constituir em um espaço cultural de produção da linguagem escrita, ao construir diálogos entre o conhecimento científico e os conhecimentos trazidos pelos alunos em torno de textos escritos. Mas, para isso, é importante refletir sobre as práticas que temos desenvolvido nas aulas de Ciências para o letramento dos estudantes.

\footnotetext{
${ }^{5}$ Nesse artigo, Castro, 2009, considera analfabetos aqueles que não conseguem ler e/ ou escrever um bilhete simples, como avaliado pelo Instituto Brasileiro de Geografia e Estatística (IBGE) na realização dos censos populacionais.
} 
Ao levantar essa questão sobre letramento, me refiro não somente ao letramento científico, mas a outros tipos de letramento. De acordo com Soares (2015, parte 5), letramento pode ser compreendido como o "desenvolvimento das habilidades e dos conhecimentos necessários para que a criança faça uso competente da leitura e da escrita nas situações sociais em que a leitura e a escrita são demandadas". Soares (2015) diferencia o termo letramento de alfabetização. Para a autora, alfabetização é a aprendizagem do sistema alfabético da escrita e das regras ortográficas, enquanto letramento se refere à capacidade de fazer uso social da linguagem escrita. Segundo Soares (2015), o termo letramento surgiu no campo da educação nos anos de 1980, com o reconhecimento da importância não apenas de se saber ler e escrever, mas especialmente de saber utilizar a leitura e a escrita nas situações sociais em que a língua escrita está presente. Estes seriam processos distintos, visto que a alfabetização envolve a orientação de processos cognitivos e linguísticos para o domínio do objeto linguístico que é a língua escrita, enquanto o letramento exige o desenvolvimento de conhecimentos e habilidades de uso competente da leitura e da escrita. Mas, não são excludentes, são complementares e devem ocorrer de forma articulada nos processos de ensino-aprendizagem da leitura e da escrita.

Outra autora que traz reflexões importantes sobre o uso da linguagem escrita é Livingstone (2011). A autora usa o termo literacidade, se referindo às habilidades e competências individuais e práticas sociais necessárias para uma relação crítica com o meio, seja midiático, impresso ou digital. Nesse sentido, aborda diferentes tipos de literacidade, tais como literacidade na informação, literacidade nas mídias, literacidade no impresso e literacidade comunicacional. A autora, a partir de um levantamento da literatura, considera três dimensões importantes da literacidade. Primeiro, esclarece que essa é uma forma de conhecimento com continuidades claras em relação às formas comunicativas (impresso, audiovisual, interpessoal, digital). Assim, pensar e discutir leitura e escrita hoje não se refere apenas ao papel, ou às palavras escritas, mas à leitura e à escrita das várias formas comunicativas atuais. Segundo, é um "conhecimento que interliga a habilidade individual e as práticas sociais que são possibilitadas (ou impedidas) por recursos (ou capitais) econômicos, culturais e sociais (distribuídos desigualmente)" (LINVINGSTONE, 2011, pg. 21). A literacidade não é uma técnica neutra e necessariamente inclusiva, depende do contexto cultural, político e social em que está inserido. Aqui podemos 
retomar a relação entre as possibilidades de literacidade e a desigualdade educacional e social e refletir sobre a importância de se entender que letramento tem acontecido nas escolas e de que forma. Em terceiro lugar, a literacidade envolve uma série de competências reguladas socialmente, englobando tanto o que é valorizado como norma, quanto o que é visto como transgressor. Nesse contexto, Cassiani-Souza e Almeida (2005), autoras que pensam sobre as relações entre leitura, escrita e ensino de Ciências, chamam atenção sobre como diferentes conexões com a cultura escrita dos alunos são muitas vezes ignoradas na escola, valorizando-se apenas determinadas formas de leitura e escrita. Em nossa investigação, buscamos entender melhor que formas são essas valorizadas pela escola no ensino de Ciências.

Resultados de avaliações em larga escala nacionais e internacionais mostram dificuldades que nossos alunos encontram em leitura e escrita (ao menos nessa maneira mais acadêmica e valorizada pela escola). Reconhecemos que tais resultados precisam ser problematizados. Bauer et al (2015) colocam que críticas têm sido feitas à utilização de resultados de avaliações em larga escala como instrumentos de gestão de redes de ensino, especialmente em relação aos seus usos como critério para alocação de recursos em escolas com melhor desempenho, definição de bônus para professores, estabelecimento de rankings estimulando a competição entre escolas e redes de ensino, e seu entendimento como indicador único e principal da qualidade de ensino. No entanto, tais medidas têm sido usadas como norteadoras de políticas e programas educacionais, por isso as consideramos para um panorama inicial.

De acordo com os resultados de proficiência em leitura obtidos no Programa Internacional de Avaliação de Alunos (PISA) de $2015^{6}$, a maioria dos estudantes no Brasil (44\%) ainda estão no nível 1 de proficiência em leitura (em uma escala de 1 a 6) (INEP, 2016 a). Isso significa que no máximo conseguem "localizar fragmentos de informação explícita, reconhecer o assunto principal de um texto

\footnotetext{
${ }^{6}$ O Programa Internacional de Avaliação de Estudantes (PISA) foi criado pela Organização para Cooperação e Desenvolvimento Econômico (OCDE) em 1997 para acompanhar e comparar o desempenho de estudantes dos países membros da OCDE e mais 35 países/ economias parceiras, incluindo o Brasil. O PISA avalia trienalmente o que alunos com 15 anos (a maioria no final da educação obrigatória na maior parte dos países) adquiriram em relação a conhecimentos e habilidades em leitura, ciências e matemática, incluindo também questionários contextuais dos estudantes e das escolas. No Brasil, o PISA faz parte do conjunto de avaliações coordenado pelo Instituto Nacional de Estudos e Pesquisas Educacionais Anísio Teixeira (INEP) (INEP, 2017 a).
} 
sobre assuntos conhecidos ou fazer correlações simples entre informações do texto e seu conhecimento cotidiano" (INEP, 2016 a, p. 268). Os resultados mostram ainda que os jovens brasileiros têm melhor desempenho em itens com textos representativos de situações pessoais (como e-mails, mensagens instantâneas, blogs, biografias e textos informativos) do que textos representando situações públicas (que incluem textos oficiais, notícias, notas públicas). Evidenciou-se ainda que os estudantes têm dificuldade com textos que combinam parágrafos em prosa com gráficos, listas e/ou tabelas. $\mathrm{Na}$ análise dos resultados para cada item da avaliação, há indícios de que "tiveram dificuldade em integrar ideias e fragmentos de informação para fazer comparações ou estabelecer relações de causa e efeito, processar informações implícitas e fazer suposições a partir dos fatos apresentados em textos narrativos ou expositivos" (INEP, 2016 a, p. 269). Os resultados mostram ainda um alto índice de respostas omitidas $(9,4 \%$ dos itens de avaliação de letramento em leitura não foram respondidos), especialmente em itens que exigiam respostas abertas. No geral, em comparação com outros países, o desempenho médio dos jovens brasileiros foi significativamente inferior às médias dos estudantes dos países da Organização para Cooperação e Desenvolvimento Econômico (OCDE) - 407 e 493, respectivamente - em relação ao letramento em leitura.

Resultados do Sistema de Avaliação da Educação Básica (SAEB)/ Prova Brasil $^{7}$ de 2015, corroboram o que foi destacado, ao mostrarem que um grande percentual de estudantes brasileiros do nono ano do ensino fundamental de escolas públicas apresenta desempenho em língua portuguesa (que avalia habilidades de leitura) até o nível 2 de proficiência (em uma escala de 0 a 9). Na escala do SAEB, isso significa, por exemplo, que provavelmente a maioria desses estudantes não é

\footnotetext{
${ }^{7}$ O Sistema de Avaliação da Educação Básica (SAEB) também é coordenado pelo INEP. De acordo com o órgão, o SAEB foi criado em 1990 para oferecer subsídios à formulação e monitoramento de políticas públicas para educação, avaliar os sistemas de ensino brasileiros, além de produzir informações sobre fatores do contexto socioeconômico, cultural e escolar que influenciam o desempenho dos estudantes brasileiros (INEP, 2017 b). Atualmente, o SAEB é composto por três avaliações externas bianuais em larga escala: 1) a Avaliação Nacional da Educação Básica (Aneb) - avaliação amostral de estudantes das redes públicas e privadas do país, em áreas urbanas e rurais, matriculados no $5^{\circ}$ e $9^{\circ}$ anos do ensino fundamental e no $3^{\circ}$ ano do ensino médio, em leitura e matemática; 2) a Avaliação Nacional do Rendimento Escolar (Anresc) - denominada Prova Brasil, avaliação censitária dos estudantes do $5^{\circ}$ e $9^{\circ}$ anos do ensino fundamental das escolas públicas das redes municipais, estaduais e federal, em leitura e matemática; e 3) Avaliação Nacional da Alfabetização (ANA) - censitária dos estudantes do $3^{\circ}$ ano do ensino fundamental das escolas públicas, para avaliar os níveis de alfabetização e letramento em língua portuguesa e em matemática.
} 
capaz de localizar informações explícitas em artigos de opinião ou reportagens; localizar a ideia principal em manuais, reportagens, notícias, resenhas e artigos; reconhecer relações de causa e consequência em reportagens e artigos; inferir tema, tese e ideia principal em artigos; diferenciar fato de opinião ou diferenciar opiniões distintas em artigos e reportagens, entre outros. Sendo que grande parte dos estudantes (aproximadamente 15\%) está no nível 0 da escala e possivelmente não consegue nem ao menos reconhecer expressões características de tipos diferentes de linguagem, como científica, jornalística, etc. (INEP, 2016 b). Os resultados variam muito dentro do país, refletindo a desigualdade educacional mencionada anteriormente. Em geral, os resultados de proficiência em leitura nos municípios do Nordeste e do Norte são menores que os do Sul e Sudeste, e de áreas rurais menores que de áreas urbanas (INEP, 2016 b). De acordo com dados do INEP, em 2015 no Rio de Janeiro a média de desempenho em língua portuguesa dos alunos do nono ano de escolas públicas foi bastante semelhante à média do Brasil (253 e 252 pontos na escala de proficiência, respectivamente). Em relação a essas avaliações, destacamos que os resultados do nono ano, que avaliam o final do segundo segmento do fundamental, em comparação com os resultados do quinto ano, têm sido piores. Isto é, no final do segundo segmento do ensino fundamental os alunos estão mais distantes das metas estabelecidas pelo Ministério da Educação que no final do primeiro segmento. Isso fortalece a ideia de que precisamos entender como a relação com a cultura escrita tem se estabelecido nessa fase da escolaridade. Reforçamos que esses dados precisam ser analisados com cautela, é preciso refletir sobre a forma que essas avaliações têm sido feitas e como têm sido utilizadas. É importante ainda considerar outros aspectos que não aparecem nessas avaliações, observar de que forma produções de leitura e escrita aparecem efetivamente na escola, pensar no que estudantes e professores têm realmente realizado. Utilizamos tais resultados apenas como um indício de que precisamos refletir melhor sobre a questão da formação escolar para leitura e escrita, realizando mais pesquisas no tema.

Em suma, considerando as dificuldades que os alunos apresentam em leitura e escrita e a importância dessas atividades para o acesso mais igualitário ao conhecimento formal e à participação nas sociedades atuais, o objetivo geral da pesquisa realizada foi entender relações entre atividades pedagógicas do ensino de Ciências e atividades de leitura e/ou escrita dos estudantes. 
Defendemos que é preciso compreender como a leitura e a escrita têm surgido nos diferentes espaços e tempos da escola, entre eles as aulas de Ciências. Temos como hipótese que características dessa área de ensino podem ajudar na formação de alunos leitores e escritores ao possibilitarem diferentes formas de produção de linguagem escrita, especialmente práticas pedagógicas específicas, como descrição de ambientes, fenômenos naturais e seres vivos; uso e descrição de experimentos; desenvolvimento de modelos didáticos; e a leitura de textos de divulgação científica, entre outros. Além disso, parece-nos que o desenvolvimento de aspectos cognitivos relacionados ao raciocínio científico, por exemplo, a criação de hipóteses, a argumentação, a abstração, etc., podem favorecer a elaboração do pensamento conceitual e assim, o aprimoramento da capacidade de leitura e de escrita. Buscamos olhar para essas especificidades do ensino de Ciências e entender se realmente favorecem a leitura e a escrita e de que forma isso acontece.

Muitas pesquisas vêm sendo realizadas na articulação entre estudos da linguagem e educação científica e destacam a importância de se pensar sobre aspectos específicos da linguagem para aprendizagem de Ciências. Esses trabalhos incluem reflexões sobre os múltiplos sentidos da linguagem, a importância do letramento científico, as possibilidades de autoria na aprendizagem de temas científicos, formas de escrita nas ciências em comparação com a escrita nas aulas de Ciências, dentre outras questões. Mais especialmente, em relação à leitura e/ou à escrita, há diversas investigações sobre o uso de textos nas aulas de Ciências com o objetivo central de refletir sobre formas de qualificar o ensino-aprendizagem das ciências.

Andrade et al (2015) fizeram uma análise dos trabalhos sobre leitura e educação em ciências apresentados de 1997 até 2013 nos Encontros Nacionais de Pesquisa em Educação em Ciências (ENPEC), importante congresso da área de pesquisa em educação nas ciências. Seus resultados mostram que nesse período em média $2 \%$ dos trabalhos tratavam desse tema. Destacam o crescente reconhecimento pelos pesquisadores e pesquisadoras do papel da linguagem como constitutiva das identidades, sentidos e práticas educativas, de textos como mediadores culturais e da alfabetização/letramento científico como um dos objetivos do ensino de Ciências. As autoras discutem a necessidade de maior esclarecimento sobre os referenciais teóricos-metodológicos dessas investigações, 
não indicados na maior parte das pesquisas, e chamam atenção para a ocorrência de dispersão de temáticas, disciplinas escolares e níveis de ensino das investigações. Há um número um pouco maior de pesquisas envolvendo a análise de diferentes tipos de textos usados no ensino de disciplinas científicas e um destaque a pesquisas no Ensino de Física. A pesquisa que realizamos pode contribuir com o desenvolvimento do campo ao se somar às investigações que vem sendo feitas, aprofundando a compreensão de práticas pedagógicas que envolvem leitura na disciplina escolar Ciências. Poderia ainda auxiliar no preenchimento de lacunas investigativas sobre a produção escrita na disciplina escolar Ciências.

Outra publicação importante que envolve o levantamento de produções na relação entre linguagem escrita e o ensino de Ciências é a de Suisso e Galieta (2015). As autoras fizeram uma busca nos principais periódicos nacionais da área de ensino de ciências de publicações que relacionam leitura, escrita e alfabetização/letramento científico. Encontraram um número limitado de artigos, destacando a importância de realizar mais pesquisas nessa articulação. Colocam que as publicações estabelecem vínculos superficiais na relação entre aprendizagem de Ciências $\underline{e}$ de leitura/escrita e não consideram especificidades da aprendizagem da leitura/escrita nas Ciências. Por outro lado, destacam que nos artigos empíricos analisados há o pressuposto implícito de que a habilidade de ler/escrever quando o conteúdo é científico difere da habilidade de ler/escrever outros temas. Em relação a esses resultados, defendemos que é relevante tentarmos entender em que aspectos essas habilidades diferem e como se articulam. Nesse sentido, proponho uma nova perspectiva de análise. Não pensar questões de leitura e escrita nas Ciências e nem leitura e escrita $\underline{e}$ Ciências. Mas sim, pensar no ensino de Ciências para leitura e escrita. Os estudos mencionados são fundamentais para a compreensão acerca do ensino-aprendizagem de ciências e para reflexões sobre o papel da linguagem nesse processo. Porém, refletimos sobre outro ponto de vista. Propomos um deslocamento na perspectiva não de centralizar o ensino-aprendizagem de Ciências, e sim o ensino-aprendizagem da leitura e da escrita. Acreditamos, como destacam os estudos mencionados, que é preciso saber ler e escrever para aprender Ciências. Mas, defendemos que aprender Ciências também pode ajudar a saber ler e escrever. Orientações dos Parâmetros Curriculares Nacionais de Ciências Naturais ${ }^{8}$

\footnotetext{
${ }^{8}$ Reconhecemos que os Parâmetros Curriculares foram elaborados há muito tempo e tem perdido espaço politicamente. Além disso, diversos autores da área de educação publicaram críticas a esses
} 
para o ensino fundamental corroboram com essa ideia ao colocarem que o ensino de Ciências pode favorecer a aprendizagem da leitura e da escrita (BRASIL, 1997, pg.62):

Desde o início do processo de escolarização e alfabetização, os temas de natureza científica e técnica, por sua presença variada, podem ser de grande ajuda, por permitirem diferentes formas de expressão. Não se trata somente de ensinar a ler e escrever para que os alunos possam aprender Ciências, mas também de fazer usos das Ciências para que os alunos possam aprender a ler e a escrever.

Tais documentos se referem ao primeiro segmento do ensino fundamental. Porém, parece-nos que as potencialidades do ensino de Ciências para o desenvolvimento das capacidades de leitura e de escrita continuam válidas ao longo de toda escolaridade. Na pesquisa, procuramos entender mais profundamente de que forma isso acontece.

Cassiani-Souza et al (2012) destacam as contribuições que seu grupo de pesquisa tem realizado com investigações acerca das relações entre o funcionamento de textos e o ensino de Ciências Naturais. Enaltecem o papel dessa disciplina na formação para leitura e escrita, focando a questão da autoria e das histórias de leitura vivenciadas nesse espaço, corroborando com a ideia de que o espaço das aulas de Ciências pode ser também um espaço para formação de leitores e escritores. Olhamos também para essas relações, buscando contribuir para as reflexões de como se estabelecem.

Silva (1998) coloca que todo professor, independente da disciplina escolar em que atua, é corresponsável pela formação de leitores e autores. Todo professor é um professor de linguagem. É a linguagem que nos permite ensinar e aprender, tanto a oral quanto a escrita. Nesse sentido, é relevante refletir sobre a contribuição das diferentes disciplinas escolares na produção da linguagem escrita, incluindo a disciplina Ciências, como propomos nesse estudo. Considerando as reflexões

documentos (por exemplo, Macedo e Lopes, 2002). No entanto, eles ainda aparecem muitas vezes como referência nas escolas. Além disso, trazem questões sobre as quais ainda precisamos refletir.

A Base Nacional Comum Curricular (BNCC) (BRASIL, 2017) para o ensino fundamental, documento político curricular recente que substituiu os PCN, menciona brevemente a aprendizagem da leitura e/ou da escrita ao colocar que uma das competências que devem ser trabalhadas nessa fase da escolaridade é a utilização de diferentes formas de linguagem para expressão, incluindo a escrita. Menciona também que o ensino de Ciências deve buscar o letramento científico e oferecer oportunidades para que os estudantes desenvolvam relatos de informações de forma oral, escrita e multimodal. 
colocadas, na próxima seção do texto apresentamos as questões de pesquisa e seu objetivo principal, destacando as perguntas que guiaram a investigação.

\title{
1.1.
}

Questões de pesquisa

\author{
Para o espírito científico, todo \\ conhecimento é resposta a uma pergunta. \\ Se não há pergunta, não pode haver \\ conhecimento científico. Nada é evidente. \\ Nada é gratuito. Tudo é construído \\ (Bachelard, 2005, pg. 18).
}

O objeto da pesquisa relatada é o trabalho realizado com a linguagem escrita na disciplina escolar Ciências. O objetivo principal é analisar atividades pedagógicas realizadas no ensino de Ciências que são associadas ao ensinoaprendizagem da leitura e/ou escrita. A questão principal da investigação pode ser sintetizada da seguinte forma: que relações podem ser estabelecidas entre atividades pedagógicas de aulas da disciplina escolar Ciências e possibilidades de leitura e/ou escrita dos estudantes? Ou mais especificamente, em que medida as aulas de Ciências são espaços de desenvolvimento de habilidades de leitura e/ou escrita, entendidas numa perspectiva sociointeracional?

Para refletir sobre as questões principais, as perguntas que guiaram a pesquisa foram:

- Qual a concepção de professoras e estudantes de ciências sobre o potencial de desenvolvimento de leitura e escrita em aulas de ciências? Que concepções de leitura e de escrita aparecem em seus discursos e práticas?

- Que atividades pedagógicas das aulas de ciências envolvem atividades de leitura e/ou de escrita? Como essas atividades de leitura e/ou de produção textual são realizadas e como os diálogos são desenvolvidos nesses processos?

- Que conhecimentos e estratégias são mobilizadas na realização de atividades de leitura e/ou de escrita em aulas de Ciências?

- Que tipos de gêneros discursivos circulam nas aulas de ciências? Como participam dos processos de ensino-aprendizagem de leitura e/ou escrita? 
- Como as diferentes tradições e enfoques curriculares da disciplina escolar Ciências se articulam a atividades de leitura e escrita?

Acreditamos que existem atividades pedagógicas que tradicionalmente ocorrem no ensino de Ciências que favorecem o desenvolvimento de algumas "expertises" em leitura e escrita, ampliando o potencial de processamento textual pelos alunos. Nesse sentido, defendemos a tese de que há especificidades na disciplina escolar Ciências que podem contribuir para o ensino-aprendizagem da leitura e da escrita. Pretendemos olhar para essas especificidades e analisá-las.

Esclarecendo a organização do texto, no próximo capítulo apresentamos os referenciais teórico-metodológicos que contribuíram para aprofundar os conhecimentos sobre o objeto de pesquisa e guiaram nosso olhar para construção da empiria e de interpretações que respondam às questões colocadas. $\mathrm{O}$ capítulo dos referenciais é composto por duas subseções: uma com discussões sobre linguagem, leitura e escrita, em uma perspectiva bakhtiniana; e outra com reflexões sobre a disciplina escolar Ciências. Nesse capítulo, apresentamos também diálogos com a revisão bibliográfica realizada para a pesquisa. Depois, apresentamos o capítulo que descreve a construção do campo empírico, destacando as categorias analíticas utilizadas. A seguir, colocamos o capítulo com os resultados, trazendo as reflexões que construímos sobre as relações entre as aulas de Ciências e processos de ensinoaprendizagem para leitura e para escrita. Dividimos a apresentação dos resultados em uma primeira parte que discute as concepções das professoras de Ciências e estudantes sobre leitura e escrita; outra com reflexões mais gerais sobre o dialogismo estabelecido nas aulas de Ciências entre os textos, as professoras e os estudantes; e uma terceira parte com discussões sobre atividades pedagógicas das aulas de Ciências e as possibilidades de leitura e de escrita. Chegamos então às considerações finais, nas quais construímos uma síntese da pesquisa realizada e dos resultados observados e levantamos as incertezas que nos restam e estudos que ainda precisam ser realizados, esperando contribuir com novos conhecimentos sobre o ensino de Ciências e o ensino-aprendizagem da linguagem escrita. 


\title{
2 \\ Referenciais teórico-metodológicos: a construção de um olhar para a pesquisa
}

\author{
Porque a nossa própria ideia - seja \\ filosófica, científica, artística - nasce e se \\ forma no processo de interação e luta com \\ os pensamentos dos outros, e isso não pode \\ deixar de encontrar o seu reflexo também \\ nas formas de expressão verbalizada do \\ nosso pensamento. (BAKHTIN, 2016, pg. \\ $59)$.
}

A investigação relatada encontra-se em uma zona de fronteira entre distintas áreas de conhecimento. Isto é, trata-se de uma investigação cujo objeto depende da contribuição de referenciais de diferentes campos de pesquisa para ser estudado; nesse caso, referenciais ligados ao campo dos estudos da linguagem em diálogo com outros relacionados à área de pesquisa em educação em ciências.

$\mathrm{Na}$ presente seção do texto, discutimos os referenciais teóricometodológicos que direcionaram nosso olhar para construção dos dados e para as análises realizadas, destrinchando os conceitos que mais têm contribuído para as reflexões. No campo da linguagem, dialogamos com a perspectiva bakhtiniana, em um entendimento sociointeracionista da língua, buscando conceitos do próprio Bakhtin e de outros autores que nos ajudaram a pensar sobre linguagem e mais especificamente, sobre leitura e escrita, especialmente Koch. Dentre os referenciais utilizados em pesquisas em educação em Ciências, trago contribuições de Goodson, do campo da história das disciplinas escolares, para pensar na constituição da disciplina escolar Ciências e autoras brasileiras que têm pensado sobre o ensino de ciências no Brasil, em diálogo com o autor, tais como Lopes, Gomes, Selles, Marandino e Ferreira. Utilizamos também trabalhos de outros pesquisadores que têm refletido sobre as questões de linguagem no ensino de Ciências, na busca de elaboração de diálogos com o nosso objeto. Nesse sentido, buscamos o apoio de Sutton e Mortimer et al, entre outros.

Como reflexo da zona de fronteira na qual a presente investigação se encontra, dividimos este capítulo em duas seções principais, uma contendo discussões de estudos da linguagem e outra com contribuições da pesquisa no ensino de Ciências, na qual acrescentamos a revisão com publicações do tema 
investigado. A seguir, apresentamos a seção com as reflexões sobre linguagem e os processos de leitura e de escrita.

\title{
2.1.
}

\section{Linguagem}

\begin{abstract}
A linguagem, mesmo sofrendo uma codificação permanente, preserva sempre uma dimensão rebelde, que escapa a todas as codificações. Nela, reconhecemos a realidade constituída e nos defrontamos com a realidade que estamos inventando [...] Nela, cada um pode apreender o mundo que já foi criado e pode antever o mundo possível das criações que ainda não aconteceram. (KONDER, 1997)
\end{abstract}

Delinear a concepção de linguagem com a qual trabalhamos é fundamental para evitar uma percepção pragmática e tecnicista da língua e da educação. Pensar sobre linguagem em uma perspectiva sociointeracionista permite construir análises mais críticas, com possibilidades para repensarmos a linguagem na escola. É um desafio encontrar o equilíbrio na tensão entre o pragmatismo de visões mais objetivas e tecnicistas da língua e da educação e a abstração excessivamente teórica, muito distante da prática em sala de aula. Não sei se conseguimos encontrar esse meio termo, mas, como pesquisadora em educação e professora, esse parece um horizonte necessário.

Bakhtin e o chamado Círculo de Bakhtin são pensadores da linguagem. Seus estudos marcaram uma nova forma de ver o mundo, o sujeito no mundo e a concretude da relação humana com a linguagem. A questão bakhtiniana principal é compreender, considerando as diferenças, o plano da produção dos bens materiais e o plano da produção dos bens simbólicos, através das relações entre linguagem, sociedade e história. Para Bakhtin, a linguagem é constitutiva do sujeito, é através dela que nos tornamos humanos e adquirimos consciência individual e social. Ao refletir sobre a relação entre linguagem e sociedade, coloca que "todos os diversos campos da atividade humana estão ligados ao uso da linguagem" (BAKHTIN, 2016, pg. 11), portanto, atuamos no mundo através da linguagem, ela é produto da atividade humana e reflete a vida social. Diferente de outros estudiosos que defendem que a linguagem é instrumento do pensamento, que apenas expressa o que pensamos, na perspectiva bakhtiniana é a partir da linguagem que construímos 
nossos pensamentos e interagimos com o mundo. Assim, a língua não é mero instrumento, mas material e produtora do próprio pensamento e de nossa existência.

De forma breve, a língua pode ser compreendida como um fato social que se funda nas necessidades de comunicação humana. É através da interação social que a língua nasce e vive. Nesse sentido, a linguagem depende da existência do outro; a alteridade é central na obra de Bakhtin. Claro que a interação implica em conflitos, relações de dominação e de resistência, adaptação ou resistência à hierarquia social, uso da língua como forma de reforçar o poder dominante, etc. (BAKHTIN - VOLOCHÍNOV, 1990). Na visão do autor, a língua está ligada às condições de comunicação, que, por sua vez, se relacionam sempre às estruturas sociais. Nesse contexto, se essas estruturas mudam, a língua também muda; sendo a recíproca também válida, isto é, se a língua muda, a estrutura também muda. A variação é inerente à linguagem (BAKHTIN - VOLOCHÍNOV, 1990). Sua teoria coloca que a língua possui componentes estáveis e instáveis, que permitem a criação. Vivemos em uma tensão entre sentidos estabilizados da linguagem e a busca de novos sentidos. É pela linguagem, na linguagem e com a linguagem que os feixes de sentidos se constroem, dialogam e disputam espaço, instaurando-se como signos ideológicos. Seria essa instabilidade de sentido dos signos que permitiria a transformação da ideologia e, consequentemente, das estruturas. Assim, para estudos sobre a linguagem, é fundamental pensar no contexto de sua produção e nas disputas ideológicas que estão em jogo. Há muitas dimensões da sociedade que podem ser compreendidas através dos estudos da linguagem, entre elas as relações de ensino e aprendizagem.

\subsection{1.}

\section{Enunciados e gêneros discursivos}

Na perspectiva bakhtiniana, a língua se organiza em forma de enunciados que podem ser compreendidos como uma réplica do diálogo social e compõem a unidade de base da língua, a unidade da comunicação discursiva. É importante esclarecer que, nessa teoria, o conceito de diálogo é compreendido como qualquer comunicação discursiva, ideia muito mais ampla, portanto, que a comumente entendida, isto é, apenas como comunicação oral face-a-face (BAKHTIN - VOLOCHÍNOV, 1990). Assim, o diálogo social compreende todas 
as atividades comunicativas humanas na sociedade, sendo constituído pelos enunciados proferidos no uso da linguagem. Dessa forma, os enunciados são de natureza social e ideológica, e formam a concretude da língua. É através de enunciados concretos que a língua passa a integrar a vida e "é igualmente através de enunciados concretos que a vida entra na língua" (BAKHTIN, 2016, pg. 1617).

Em síntese, os enunciados são decorrentes do contato da língua com a realidade, o que ocorre na interação discursiva dialógica. Nesse sentido, entendemos que para estudos sobre a linguagem é preciso olhar para os enunciados, através da análise dos diálogos. O dialogismo é princípio básico para o desenvolvimento da linguagem e é constitutivo de todo discurso, é a condição do sentido do discurso: tanto o dialogismo da interação entre o enunciador e o enunciatário, quanto o dialogismo da interdiscursividade, no interior do discurso. Essa interdiscursividade é resultado da constituição dos enunciados a partir de enunciados de discursos anteriores que, por sua vez, são construídos por outros discursos que formam esses discursos e assim sucessivamente, de forma que cada enunciado será constituído por vários discursos.

O objeto do discurso de um locutor, seja ele qual for, não é objeto do discurso pela primeira vez neste enunciado, e este locutor não é o primeiro a falar dele. O objeto, por assim dizer, já foi falado, controvertido, esclarecido e julgado de diversas maneiras, é o lugar onde se cruzam, se encontram e se separam diferentes pontos de vista, visões de mundo, tendências (...) O enunciado está voltado não só para o seu objeto, mas também para o discurso do outro acerca desse objeto. A mais leve alusão ao enunciado do outro confere à fala um aspecto dialógico que nenhum tema constituído puramente pelo objeto poderia conferir-lhe. (Bakhtin, 2003, p. $319-320)$

Para compreensão do conceito de enunciado na obra do autor, é relevante refletir sobre suas propriedades principais. Estas incluem o contato com a realidade (já que os enunciados decorrem de situações comunicativas concretas), a relação com enunciados alheios (aspecto dialógico dos enunciados e do discurso) e a necessidade responsiva do outro. Todo enunciado é dependente do discurso do outro e, sendo assim, enunciadores e enunciatários têm papel ativo na comunicação discursiva. Em oposição a visões linguísticas que compreendem o enunciatário como passivo, na teoria bakhtiniana o mesmo tem papel tão ativo quanto o enunciador, na medida que ao dialogar com o discurso do outro, precisará usar seus próprios conhecimentos para interagir na situação comunicativa. O enunciatário 
sempre ocupará uma posição ativa sobre o enunciado alheio, gerando algum tipo de resposta: concordando, discordando (total ou parcialmente), completando, aplicando, se preparando para usá-lo ou até silenciando, entre outras muitas respostas possíveis. Assim, cada enunciado gerará um novo enunciado como resposta e ao mesmo tempo será a resposta de um enunciado anterior, mesmo que isso não ocorra simultaneamente. Todo enunciador é um respondente e todo respondente se tornará um enunciador - um é tão relevante quanto o outro na comunicação discursiva. Dessa forma, o discurso se constitui por enunciados concretos com limites precisos, que são dependentes da alternância dos sujeitos do discurso. Cada enunciado tem início a partir dos enunciados de outros e conclusibilidade nos enunciados responsivos de outros, seja como algo falado, escrito ou simplesmente uma compreensão ativamente responsiva. A maneira como essa alternância ocorre depende das condições e situações de comunicação.

Refletindo sobre nosso objeto de pesquisa, isto é, as relações entre as aulas de Ciências e a linguagem escrita, é importante colocar que as propriedades dos enunciados são válidas mesmo para discursos mais complexos que o diálogo falado cotidiano, como textos escritos científicos e/ou científicos escolares. Embora possa parecer que não se tratam de diálogos por concentrarem o poder da palavra longamente e parecerem descontextualizados, se tratam de discursos e são, portanto, dialógicos e levarão também a atitudes responsivas. A ativa compreensão responsiva nesses casos pode aparecer como uma influência educativa sobre os enunciatários (nesse caso os leitores dos textos), sobre suas convicções, respostas críticas, incorporação do que foi colocado como atitude, ou mesmo a resposta (verbal ou silenciosa) de que não entenderam o que foi colocado, entre outras.

A alternância dos sujeitos do discurso e a conclusibilidade de cada enunciado é determinada por três elementos: i) a exauribilidade semântico-objetal; ii) o projeto de discurso; e iii) as formas típicas de acabamento do discurso. $\mathrm{O}$ primeiro e segundo elementos se relacionam fortemente. $\mathrm{O}$ tema de qualquer enunciado tem uma conclusibilidade, mesmo que relativa, que é colocada pelas intenções do autor do discurso. O sentido que o enunciador (falante ou escritor) quer produzir determina as fronteiras do enunciado (com a espera da resposta do outro). A intenção do autor se combina com o aspecto semântico-objetal e o restringe, vinculando-o a uma situação concreta de comunicação discursiva. Os 
participantes da situação comunicativa percebem essa intenção discursiva e reagem a ela.

O terceiro elemento determinante da alternância dos sujeitos do discurso e da conclusibilidade de cada enunciado, isto é, a forma de acabamento no qual o discurso é colocado, se refere a um conceito importante para nossa pesquisa, o de gênero discursivo9. Para compreender esse conceito, é importante considerar que cada enunciado reflete as condições e situações sociais específicas nas quais é produzido, incluindo as finalidades de sua produção, não só através do seu conteúdo temático e das palavras usadas, mas também a partir do estilo verbal utilizado e da construção composicional na qual acontece.

O emprego da língua efetua-se em forma de enunciados (orais e escritos), concretos e únicos, proferidos pelos integrantes desse ou daquele campo da atividade humana. Esses enunciados refletem as condições específicas e as finalidades de cada referido campo, não só por seu conteúdo (temático) e pelo estilo da linguagem, ou seja, pela seleção dos recursos lexicais, fraseológicos e gramaticais da língua, mas, acima de tudo, por sua construção composicional. Todos esses três elementos - o conteúdo temático, o estilo, a construção composicional - estão indissoluvelmente ligados no todo do enunciado e são igualmente determinados pela especificidade de um determinado campo da comunicação (BAKHTIN, 2016, p.11-12).

A construção dos enunciados reflete a intenção discursiva do enunciador e se realiza antes de tudo na escolha de certo gênero discursivo, na forma como molda o seu discurso. Essa escolha é determinada pelas especificidades de um dado campo da comunicação discursiva, pelo tema abordado (considerações semânticoobjetais), pela composição pessoal dos participantes da comunicação e pela própria situação de comunicação. Os gêneros podem ser compreendidos como formas relativamente estáveis dos enunciados, típicas de construção do conjunto discursivo e elaboradas em cada esfera da atividade humana. Cada época e cada grupo social têm seu repertório de formas de discurso na comunicação social e ideológica

\footnotetext{
${ }^{9}$ Optamos nesse trabalho por utilizar o conceito de gênero discursivo de forma distinta do conceito de gênero textual. Embora muitos autores os utilizem como sinônimos, diferenciamos os conceitos ao aproximar a ideia de gênero discursivo ao uso social do discurso e às características do campo de atividade no qual é proferido, enquanto o de gênero textual se refere predominantemente à estrutura linguística do enunciado. Rojo (2005), a partir de seus estudos, esclarece que aqueles que adotam o conceito de gêneros discursivos dão prioridade para a significação dos enunciados, para a acentuação valorativa e o tema, enquanto que aqueles que adotam os gêneros textuais, a significação é preterida e abordada apenas em relação ao conteúdo temático. Nesse sentido, a autora considera reducionista ignorar essas diferenças e trabalhar com os conceitos como se fossem iguais. Baseados em uma concepção sociointeracionista bakhtiniana, consideramos apenas o conceito de gênero discursivo, não trabalhando com o termo gêneros textuais.
} 
marcada pelos gêneros. Sendo ideologicamente determinados, operam, em certos contextos, como formas de legitimação discursiva das relações sociais, pois surgem a partir de atividades sociais, culturais, políticas e econômicas.

Aprendemos a língua através de enunciados concretos que nos chegam ao longo da vida em determinados formatos, ou seja, como gêneros do discurso proferidos em certos contextos sociais, históricos e culturais. "As formas da língua e as formas típicas dos enunciados, isto é, os gêneros do discurso, chegam à nossa experiência e à nossa consciência juntas e estreitamente vinculadas" (BAKHTIN, 2016, pg. 38-39). Assim, aprendemos a moldar nosso discurso em formas de gênero e na interação social já adivinhamos o gênero do discurso do outro nas primeiras palavras, de forma que a comunicação discursiva depende desses gêneros. E são esses gêneros que marcam os discursos e a estrutura social.

Considerando que os enunciados refletem situações comunicativas concretas e que estas são tão variáveis quanto as interações humanas, a diversidade de gêneros discursivos é muito extensa. De acordo com Bakhtin, "A riqueza e a diversidade dos gêneros do discurso são infinitas porque são inesgotáveis as possibilidades da multifacetada atividade humana" (BAKHTIN, 2016, pg. 12). Em cada campo de atividade elabora-se todo um repertório de gêneros do discurso que ao longo do tempo cresce e se diferencia à medida que o próprio campo se desenvolve e se complexifica.

Para estudar essa enorme heterogeneidade dos gêneros discursivos, o autor divide-os em dois grupos principais, os gêneros primários e os gêneros secundários do discurso. Segundo Bakhtin, estes gêneros não se diferenciam apenas funcionalmente, a diferenciação é principalmente essencial e ideológica. Gêneros primários são mais simples e se formam nas condições discursivas imediatas e diárias, em circunstâncias que o autor denomina como comunicação verbal espontânea. São por exemplo, cumprimentos, elogios, bate-papos informais, conversas telefônicas, fofocas, etc. Costumam ser associados à oralidade, mas podem também ser escritos, como em uma carta, por exemplo, ou na atualidade, em uma conversa por mensagens em redes sociais ou aplicativos utilizados em celulares. Tais gêneros são adquiridos inconscientemente no processo de socialização da criança. Historicamente, os gêneros primários são incorporados e reelaborados em campos de atividades de convívio cultural mais complexo, desenvolvidos e organizados, originando os gêneros secundários, que são 
normalmente associadas à escrita (por exemplo, os romances, as pesquisas científicas, os dramas, gêneros jornalísticos, etc.). Os gêneros secundários absorvem e transmutam os gêneros primários, de forma que adquirem características especiais: perdem a relação imediata com a realidade e com os enunciados dos outros (BAKHTIN, 2016). Nesse sentido, os gêneros primários seriam estruturados na ação, enquanto os secundários dela se separariam, se tornando autônomos em relação a uma situação imediata.

Schneuwly (2004), discute que quanto mais os discursos se afastam do contexto da ação, mais o aparelho linguístico criado na língua para falar sobre ele precisa se complexificar. Em uma das obras mais utilizadas para discussão do conceito de gêneros discursivos, Bakhtin exemplifica o processo de transmutação de gêneros primários em gêneros secundários, e sua consequente complexificação, na incorporação de um diálogo cotidiano ou uma carta pessoal a um romance. O diálogo e a carta, que antes tinham a natureza simples e primária, passam a integrar um enunciado secundário, o romance, e nesse processo, passam a fazer parte de um acontecimento literário, e não mais da vida cotidiana e passam a exigir uma linguagem mais complexa que explique os contextos em que ocorreram (BAKHTIN, 2003).

Dentro de cada grupo dos gêneros primários e secundários há uma infinidade de gêneros mais específicos, alguns mais padronizados e outros mais flexíveis. Na presente investigação, além de observar a natureza mais ampla dos gêneros discursivos utilizados em aulas de Ciências (se primários ou secundários), analisamos os gêneros discursivos mais específicos associados a eles, especialmente no estudo dos textos dos materiais didáticos das aulas, articulado aos seus usos concretos nas salas de aula. $\mathrm{Na}$ análise, consideramos os textos como materialização dos discursos (FIORIN, 2012) e estudamos os aspectos sóciohistóricos da situação de interação, refletindo sobre a finalidade do produtor e sua apreciação valorativa sobre seu interlocutor e o tema discursivo e buscando as pistas linguísticas que refletiam no texto esses aspectos. Entendemos, assim, que os gêneros do discurso não são formas fixas da língua, mas regularidades e similaridades discursivas, formadas a partir das relações sociais estabelecidas em uma dada esfera da comunicação. Assim, afirmamos que a caracterização dos gêneros do discurso, em uma perspectiva bakhtiniana, deve ser realizada a partir de práticas sócio discursivas concretas, e não simplesmente de aspectos linguísticos e 
estruturais. Na investigação realizada, os gêneros discursivos dos materiais e dos discursos das professoras e alunos foram analisados considerando a situação comunicativa vivenciada na escola, e mais especificamente nas aulas de Ciências.

Gêneros discursivos são fenômenos históricos, vinculados à vida cultural e social. Nesse sentido, alguns exemplos de gênero mais específicos, incluindo gêneros primários e secundários, seriam: uma conversa informal, telefonema, carta comercial, e-mail, artigo científico, texto de divulgação científica, texto literário, bilhete, aula expositiva, debate, mapas, receitas culinárias, bula de remédio, lista de compras, cardápio, texto virtual em ambiente de aprendizagem, textos de blogs, textos de redes sociais, dissertação escolar, edital de concurso, etc. Há sempre novos gêneros se formando, a partir do amadurecimento de novos campos de comunicação e atividade humana. Na investigação, entendemos as aulas de Ciências como um desses campos de comunicação humana, e, portanto, um lugar de geração e propagação de gêneros discursivos nas enunciações que circulam nesse espaço.

Em relação aos gêneros e ao ensino, Marcuschi (2003) traz contribuições importantes ao colocar que devemos ensinar e aprender a produzir textos e não enunciados soltos e que isso exige o trabalho com variados gêneros e a constante reflexão sobre eles. Segundo o autor, não devemos supor que estudantes aprendem naturalmente a produzir os diversos gêneros escritos formais, ou mesmo os de uso diário; é preciso pensar sobre isso e ter os gêneros como referencial analítico nos processos de ensino e aprendizagem na escola. Essa é uma discussão importante para o ensino de Ciências. Que gêneros discursivos circulam nas aulas de Ciências (nos discursos, nas atividades propostas e nos materiais didáticos)? Como esses gêneros discursivos aparecem? Quais as suas funções sociais? Participam do aprimoramento da capacidade de leitura e/ou escrita dos alunos? De que forma? Há apropriação pelos alunos de que gêneros discursivos nas aulas de Ciências?

Reflexões sobre a apropriação dos gêneros discursivos nos remetem à discussão bakhtiniana sobre autoria. O tema do autor e da autoria é muito importante na perspectiva de Bakhtin, visto que aparece, em maior ou menor grau, em quase todos os escritos desse pensador (FARACO, 2008). Trata-se de tema bastante complexo, de extensa elaboração de natureza filosófica pelo pensador, sobre o qual se debruçou, principalmente, refletindo sobre o ponto de vista estético em obras literárias. Acreditamos que fugiria do escopo da pesquisa realizada o 
aprofundamento dos variados aspectos sobre autoria desenvolvidos por Bakhtin, mas apropriamo-nos de alguns elementos do debate para reflexões mais específicas sobre a formação escolar na relação com a linguagem escrita. Dias (2017), em sua pesquisa de doutorado intitulada "Há espaço para a construção autoral nos trabalhos de pesquisa escolar", traz uma discussão do conceito de autoria para entender se a atividade pedagógica pesquisa escolar possibilita o desenvolvimento de textos autorais. $\mathrm{O}$ autor destaca a polissemia do termo e se inspira na perspectiva bakhtiniana para discuti-lo. Nesse contexto, coloca que a autoria na escola se relaciona a espaços nos quais existam possibilidades de construção de sentidos pelos estudantes. Associa o conceito de autoria à ideia de alteridade e singularidade, compreendendo que autoria seria se colocar como sujeito singular em uma relação de alteridade. Para Dias (2017), agir e se posicionar no mundo seria construir autoria: "Em outras palavras, ser autor, neste caso, é olhar com lentes próprias, para um dado tema, posicionando-se, moldando-se emoções e percepções de mundo, construindo algo novo e que se torna marca própria no mundo". (DIAS, 2017, pg. 43). Porém, o pesquisador destaca que esse posicionamento, mesmo que seja novo, dependerá sempre do diálogo com outras vozes que estão no mundo. Ao dialogar com essas vozes, o autor traz sua própria voz e assim, ressignifica o que está posto. Nesse sentido, podemos pensar que todo enunciado é autoral, pois sempre será formulado por alguém que estará lhe dando algum sentido como indivíduo (estará, portanto, sempre sendo ressignificado). No entanto, entendemos que alguns enunciados podem ser mais autorais que outros, ao expressarem mais claramente a posição do seu autor ou enunciador. Em articulação com as discussões sobre gêneros discursivos, Bakhtin discute que há gêneros que são mais propícios ao reflexo da individualidade do enunciador na linguagem do enunciado (oral ou escrita) que outros. Ou seja, alguns gêneros permitem que apareça mais o estilo individual do enunciador. "Em diferentes gêneros podem revelar-se diferentes camadas e aspectos de uma personalidade individual" (BAKHTIN, 2016, pg.18). Dessa forma, alguns gêneros discursivos estimulam mais a autoria, visto que possibilitam que a posição do autor no mundo apareça mais. Gêneros de literatura de ficção seriam mais favoráveis ao aparecimento do estilo do autor (e, portanto, da autoria) que gêneros de documentos oficiais, como os jurídicos, por exemplo. Destacamos, porém, que a autoria não depende apenas do gênero discursivo, mas também da possibilidade de se apropriar do gênero e expressar sua posição no 
mundo na interação com o texto. A discussão sobre autoria contribuiu para as reflexões sobre o objeto de pesquisa, especialmente, na análise das demandas de produção textual das aulas de Ciências (se estimulam ou não a autoria) e para o estudo de espaços nas aulas que traziam as vozes dos estudantes.

Enfim, considerando a escola como um espaço de interação social e, portanto, de linguagem, diálogo e enunciação, podemos refletir sobre os discursos produzidos pelos diferentes sujeitos que ali circulam, pensar nos processos discursivos que acontecem nos diferentes espaços e tempos escolares e de que forma se organizam. A pesquisa em educação avançou muito nessa perspectiva nos últimos anos, inclusive há muitos trabalhos realizados na área de ensino de ciências com embasamento em Bakhtin, como nos mostram, por exemplo, os trabalhos de Veneu et al (2015) e Souza et al (2013) que contribuem com a apresentação de levantamentos de publicações do campo do ensino de Ciências e da área da linguagem, destacando entre os referenciais mais utilizados, a perspectiva de Bakhtin.

As investigações trazem que os professores de áreas científicas tendem a usar estratégias de ensino que monologizam o discurso, construindo afirmações aparentemente descontextualizadas, talvez como uma tentativa de levar os alunos à apropriação de discursos mais complexos que constituem o conhecimento científico. Apesar dos discursos, por sua natureza, serem sempre dialógicos, muitas vezes aparecem silenciando enunciados anteriores que os formaram e se tornam assim mais monológicos (ao menos em aparência). Aprofundamos reflexões sobre como são os discursos produzidos nas aulas de ciências em articulação com a leitura e a escrita e procuramos entender, na investigação, se no trabalho com textos escritos nas aulas de Ciências, os discursos produzidos são mais dialógicos ou monológicos e de que forma se estabelecem.

Os estudos de Bakhtin ampliam as possibilidades de compreensão sobre os processos de leitura e escrita, considerando a linguagem escrita como parte da linguagem humana. Contribuem para as reflexões da linguagem como produto e como produtora das relações humanas, sempre dialógicas. Nesse sentido, permitem um olhar para a linguagem com uma perspectiva mais crítica, percebendo que a língua nunca é transparente e que os discursos trazem múltiplas possibilidades de sentidos que refletem diferentes ideologias. A partir desse entendimento mais geral da linguagem, seguimos para discussão de aspectos mais específicos sobre leitura 
e escrita. Para isso, buscamos autores que dialogam com Bakhtin e avançam no sentido de pensar propriamente sobre leitura e escrita, objetos da nossa investigação, como discutimos na seção a seguir.

\subsection{2.}

\section{Leitura e escrita}

Refletir sobre leitura e escrita em uma perspectiva bakhtiniana inclui entender a interação social como processo central para a compreensão e a produção textual. Assim como a linguagem em geral, a linguagem escrita constrói e é construída nas interações sociais; porém, nesse caso específico, tais interações acontecem através dos textos escritos. É refletindo sobre essas interações sociais que procuramos entender como a linguagem escrita aparece e é trabalhada nas aulas de Ciências. Para isso, buscamos autores da linguística textual com uma concepção sociointeracionista da linguagem.

Koch (2003) discute o entendimento sociointeracionista das atividades de leitura e de escrita a partir do debate sobre diferentes visões de texto, de sujeito e de contexto. O texto é compreendido pela autora como lugar de constituição e interação de sujeitos sociais, no qual convergem ações linguísticas, cognitivas e sociais. Nesse sentido, trata-se de um constructo histórico e social, extremamente complexo e multifacetado. $\mathrm{O}$ texto pode ser falado ou escrito e se refere a uma maneira de enfocar a produção linguística em funcionamento, quanto a sua forma e organização. A comunicação linguística (e a produção discursiva em geral) não se dá em partes isoladas, tais como fonemas, morfemas ou palavras soltas, mas sim em partes maiores, ou seja, por textos, que materializam os enunciados. De acordo com Marcuschi (2008), o texto, a rigor, é o único material linguístico observável. É no texto que observamos os enunciados. Assim, podemos compreender o texto como a materialização do discurso e relacionar os estudos dos textos com estudos discursivos. Na investigação realizada, analisamos propostas pedagógicas que acontecem em torno de textos trabalhados em aulas de Ciências.

Como constructo social, o texto carrega em si escolhas sociais de linguagem. Cada texto, mesmo que tenha sido escrito individualmente, traz questões que são sociais. Porém, as escolhas que foram feitas dentre essas questões, são individuais. Assim, cabe questionar quanto o texto traz do sujeito enquanto indivíduo, sendo ele 
histórico, social e ideológico. Faz sentido pensar em sujeitos na concepção sociointeracionista? Koch (2003) defende que sim. Seu entendimento encontra-se entre uma concepção cartesiana individual de sujeito e a de assujeitamento. $\mathrm{Na}$ concepção cartesiana, o sujeito é um indivíduo com consciência plena, com capacidade de domínio da linguagem para transmissão exata de seus pensamentos em cada enunciado. Já na perspectiva do assujeitamento, o sujeito como indivíduo não existe, é uma ilusão. Ele é apenas o porta-voz de uma ideologia que o atravessa. Os enunciados não têm uma origem, são imemoriais, apenas carregam múltiplos sentidos derivados dos discursos a que pertenceram e pertencem. Não importa quem colocou esses discursos. Koch (2003) não corrobora com nenhuma dessas visões. A autora traz a ideia de que existe um sujeito que é psicossocial. Existem, sim, condições sociais de produção dos discursos, mas elas não anulam qualquer opção ou ação consciente dos sujeitos. O sujeito é ativo na produção do social e na interação com o outro. Como Bakhtin, Koch defende que a identidade se constrói na relação com a alteridade. O texto é uma encenação dessa relação, é um espaço da interação com o outro. Nessa interação, há sistema, mas há também sujeito. Cabe aqui um resgate da ideia de estilo trazida por Bakhtin na discussão sobre gêneros discursivos, na qual ele coloca que há sempre algum elemento estilístico, como uma marca do indivíduo, na enunciação dos gêneros. Os gêneros moldam o discurso a partir de questões sociais e ideológicas, mas dentro desse molde há escolhas individuais do sujeito. Trata-se então de uma concepção sociointeracionista da língua, que a entende como um conjunto de práticas sociais e cognitivas realizadas por sujeitos historicamente situados.

[...] o meu ponto de partida para a elucidação das questões relativas ao sujeito, ao texto e à produção textual de sentidos tem sido uma concepção sociointeracional de linguagem, vista, pois, como lugar de inter-ação entre sujeitos sociais, isto é, de sujeitos ativos, empenhados em uma atividade sociocomunicativa. (KOCH, 2003, pg. 19)

Assim, é claro que tanto a produção quanto a compreensão do texto dependem essencialmente de uma interação entre autor e leitor (enunciador e enunciatário). Essa interação ocorre em determinado contexto; é esse contexto social que dá sentido ao texto. Logo, estudos sobre o texto devem analisar o contexto de produção, que inclui: o cenário, o entorno sociocultural, a própria linguagem como contexto (a forma como a linguagem é utilizada naquele local de produção), conhecimentos prévios e a relação entre o contexto e o evento. A partir 
desses estudos, consideramos em nossa investigação o contexto de produção dos materiais didáticos - expresso nas políticas de educação que chegam nas escolas-, o contexto socioeconômico e cultural das comunidades escolares das aulas de ciências - influenciado pelas questões cotidianas que os estudantes levam para as aulas -, e a forma como a interação social acontece nos momentos de trabalho com textos.

\subsubsection{1.}

Leitura

A concepção sociointeracionista da linguagem foi também importante para reflexões sobre questões mais específicas de leitura e escrita. Nessa perspectiva, o entendimento da leitura é realizado com foco na interação autor-texto-leitor e se contrapõe às perspectivas que se focam ou no autor ou no texto.

A compreensão da atividade de leitura com foco no autor se relaciona à concepção de língua como representação do pensamento e do sujeito psicológico, individual e dono de sua vontade e de suas ações (KOCH e ELIAS, 2015). Nesse sentido, o texto é uma representação mental do autor, um produto lógico do seu pensamento. O leitor precisa apenas receber e captar essa representação mental juntamente com as intenções do autor. Se refere assim àquela concepção individual cartesiana de sujeito, desconsiderando os aspectos sociais que compõem o texto e sua produção e interpretação. Não leva em conta as experiências e conhecimentos do leitor e nem as interações que acontecem no texto. A leitura é considerada apenas uma atividade de captação das ideias e intenções do autor, que centraliza os sentidos do texto; ao leitor cabe apenas captar esses sentidos.

O foco no texto é colocado pelo entendimento da língua somente como estrutura, desconsiderando nesse caso o papel do sujeito. Apresenta a mencionada visão do sujeito como assujeitado pelo sistema, "caracterizado por uma espécie de não consciência" (KOCH e ELIAS, 2015, pg. 10). O princípio explicativo de qualquer fenômeno e/ou comportamento individual está no sistema, seja ele linguístico ou social. Como estrutura, a língua seria somente um código, uma ferramenta de comunicação, e o texto o produto da codificação de um emissor, bastando ao leitor decifrar o código utilizado. Assim, a leitura exige apenas do leitor que mantenha a atenção no texto, em sua linearidade, pois tudo está ali naquela 
estrutura. Em síntese, nas perspectivas anteriores focadas no autor, ao leitor cabia só reconhecer as intenções do autor, nas concepções com foco no texto, cabe-lhe o reconhecimento dos sentidos das palavras e estrutura do texto. Nos dois casos, o leitor se caracteriza por um papel passivo ao realizar apenas atividades de reconhecimento e reprodução.

$\mathrm{Na}$ concepção sociointeracionista da linguística textual, o foco está na interação autor-texto-leitor. Como colocado anteriormente, os sujeitos são atores sociais, sujeitos ativos que, dialogicamente, se constroem e são construídos no texto. Assim, o texto é o lugar da interação e de constituição dos interlocutores que participam ativamente do processo. O sentido do texto é elaborado na interação texto-sujeitos e não existe antes dessa interação. A leitura é compreendida como uma atividade complexa e interativa de produção de sentidos, que depende da organização do texto e dos elementos linguísticos presentes, mas também da mobilização de todo um conjunto de saberes dos participantes do evento comunicativo (KOCH e ELIAS, 2015). Dessa forma, a leitura é uma atividade que engloba as experiências e os conhecimentos do leitor, que estão além do código linguístico. O leitor interage ativamente com o texto e sempre produz algum tipo de resposta ao dar sentido e significado ao texto. Considerando que todo enunciado é prenhe de respostas, o texto - sendo formado por enunciados - demanda uma atitude responsiva do leitor que vem através da sua elaboração, crítica, contradição, avaliação, corroboração, questionamento, etc.

Nesse processo, é importante considerar que os objetivos da leitura regulam as formas de interação com o texto. São os objetivos do leitor que nortearão a leitura, com mais ou menos atenção, com mais ou menos tempo, com maior ou menor dedicação à interação (KOCH e ELIAS, 2015). Considerando tais objetivos, o leitor irá acessar um conjunto de conhecimentos, buscando compreender o texto.

De acordo com Koch (2003), na leitura recorremos a três grandes sistemas de conhecimentos: i) o linguístico; ii) o enciclopédico ou o conhecimento de mundo; e iii) o interacional. O conhecimento linguístico engloba o conhecimento lexical e gramatical que permite compreender a organização do material linguístico na superfície textual, o uso dos meios coesivos, a sequenciação textual e a seleção lexical adequada ao tema do texto. O conhecimento enciclopédico se refere aos conhecimentos gerais sobre questões do mundo e aos conhecimentos relacionados a vivências pessoais, que utilizamos na produção de sentidos ao interagir com os 
textos. Já o conhecimento interacional ${ }^{10}$ diz respeito às formas como a interação acontece no texto por meio da linguagem e inclui o conhecimento da situação comunicativa e suas regras, o conhecimento estilístico, o conhecimento sobre os variados gêneros adequados às diversas práticas sociais, bem como o conhecimento de outros textos que permeiam a nossa cultura (intertextualidade). É esse conhecimento que permite que o leitor reconheça o modo de organização, estilo e propósito comunicacional do texto, analisando sua adequação a uma situação comunicativa concreta.

Estes sistemas de conhecimentos participam da interação entre autor e leitor através do texto e precisam ser, ao menos em parte, compartilhados. Eles compõem o contexto sócio-cognitivo dos participantes da interação, englobando todos os tipos de conhecimentos arquivados na memória dos sujeitos sociais (KOCH, 2003). Assim, o contexto sócio-cognitivo inclui o contexto (entorno verbal do texto), a situação imediata de interação e a situação mediata (sociopolítica-cultural). No processo da leitura, o contexto sócio cognitivo do leitor precisa ser compartilhado de alguma maneira com o contexto sócio cognitivo do autor, de forma que possam se compreender mutuamente.

O leitor busca produzir sentido para o que lê recorrendo aos seus conhecimentos sócio-cognitivos, interacionalmente construídos. Se ele é capaz de dar sentido ao texto, na situação concreta de interação, esse lhe parece um texto coerente. A coerência é um princípio de interpretabilidade do discurso. Nesse sentido, segundo Koch e Elias (2015), a coerência não está no texto em si, são os leitores no processo efetivo de interação com o autor e o texto que constroem coerência, a partir dos seus conhecimentos e da forma, estrutura e organização do texto.

\begin{abstract}
Assumindo como pressuposto que o texto é coerente, o leitor busca interpretá-lo, produzir sentido, em uma verdadeira atitude de cooperação. Com base em conhecimentos que possui, cabe-lhe a tarefa de estabelecer elos coesivos que não foram explicitados entre as ideias do texto - e quanto mais informações tiver, mais terá a possibilidade de fazê-lo. A coerência,
\end{abstract}

\footnotetext{
10 De acordo com Koch e Elias (2015), o conhecimento interacional pode ser dividido em ilocucional, comunicacional, metacognitivo e superestrutural. De forma breve, o conhecimento ilocucional se refere à possibilidade de compreender os objetivos e propósitos do autor ou enunciador. O comunicacional diz respeito às normas comunicativas gerais, como reconhecer a adequação da quantidade de informação necessária para construção de sentido no texto, assim como a seleção da variante linguística e tipos textuais utilizados. O metacognitivo se refere aos apoios textuais e marcas usadas no texto. Finalmente, o superestrutural relaciona-se às estruturas e modelos gerais, principalmente ao reconhecimento da estrutura de determinados gêneros textuais.
} 
portanto, não está apenas no texto, nem tampouco apenas no autor ou nos leitores, mas na interação autor-texto-leitor. (KOCH e ELIAS, 2015, pg. 194)

Aqui cabe esclarecer que nessa perspectiva, o sentido do texto nunca será único e irá variar para cada leitor que interage com ele. Um mesmo texto apresenta uma pluralidade de leituras e de sentidos possíveis, visto que só adquire sentido no momento da interação com o leitor e que cada leitor terá conhecimentos e experiências únicas que farão parte dessa interação. Porém, nem toda leitura é possível, não se pode criar qualquer sentido, há limites impostos pela organização e sistema linguístico do texto e pelos autores e leitores. Esses limites molduram a interação e permitem o próprio evento comunicativo. A pluralidade de leituras e sentidos poderá ser maior ou menor dependendo do texto (forma de composição e conteúdo) e da maneira como os conhecimentos são ativados pelo leitor.

Para acessar seus conhecimentos e dar sentido ao texto, o leitor recorre a uma série de estratégias sócio-cognitivas. Podemos dizer que a interpretação dos textos é estratégica, pois os leitores, diante de um texto, "realizam simultaneamente vários passos interpretativos finalisticamente orientados, efetivos, eficientes, flexíveis e extremamente rápidos" (mesmo que não se deem conta deles) (KOCH e ELIAS, 2015, pg. 39). Essas estratégias consistem em hipóteses operacionais construídas no momento de interação sobre a estrutura e o significado de um fragmento ou de um texto inteiro. Incluem, por exemplo, antecipações, levantamento de hipóteses - confirmadas ou refutadas ao longo da leitura -, ativação de conhecimentos arquivados na memória, inferências, comparações, perguntas sobre o texto, entre outros.

Koch e Elias (2015) chamam atenção para fatores implicados na compreensão dos textos escritos relativos ao autor/leitor ou ao texto. Entre os fatores determinantes de compreensão do texto trazidos pelo autor/leitor estão o conhecimento dos elementos linguísticos descritos no texto, esquema cognitivo dos sujeitos envolvidos, o capital cultural, e o reconhecimento das circunstâncias nas quais o texto foi produzido. Em relação ao texto, sua leitura poderá ser dificultada por aspectos materiais, linguísticos ou de conteúdo. Dentre os aspectos materiais, destaca-se tamanho e clareza das letras (ou da fonte utilizada em meios digitais), textura e qualidade do papel ou da tela, tamanho dos parágrafos, uso de abreviações, etc. Fatores linguísticos dizem respeito ao léxico utilizado, às estruturas sintáticas, 
à forma das orações (dificultam se forem orações simplificadas sem nexos causais ou espaciais, por exemplo), pontuação, entre outros. Dificuldades relativas ao conteúdo do texto se relacionam às especificidades da área de conhecimento do texto lido; quanto mais específico for o texto, com maior uso de termos próprios a determinado campo, maior será a dificuldade de interação com ele.

\subsubsection{2.}

Escrita

Além da leitura, investigamos atividades de escrita das aulas de Ciências. A concepção de escrita com a qual dialogamos é similar à de leitura, o que significa que também tem foco na interação autor-texto-leitor e se opõe às concepções com foco no autor (escritor) ou no texto. Perspectivas com foco no autor correspondem àquela ideia do sujeito individual e totalmente consciente de suas ações e da língua como representação de seu pensamento. A escrita é entendida como uma atividade por meio da qual o escritor expressa o que pensa, sem considerar o leitor ou a interação envolvida nesse processo. Compreender a escrita com foco no texto traz o sentido de que esta é uma atividade que depende apenas do conhecimento das regras gramaticais e de um vocabulário rico pelo escritor. A língua é um sistema estruturado e pronto, o sujeito é apenas determinado por esse sistema (assujeitamento). Na concepção sociointeracionista, considera-se a ação do autor (escritor) e a estrutura da língua, mas não somente isso. O produtor do texto, ao escrever, imagina um modelo de leitor, pensa sobre ele, lê o que escreveu e revê o que julga necessário a partir de um princípio interacional com esse leitor imaginado. Assim, a produção textual é realizada de acordo com as intenções de quem usa a língua para atingir determinado objetivo, levando em consideração o leitor e seus conhecimentos. Dessa forma, a escrita se realiza com base nos elementos linguísticos e na sua forma de organização, mas requer, no interior do evento comunicativo, que o escritor mobilize vários conhecimentos, incluindo o que pressupõe ser do conhecimento do leitor ou compartilhado por ambos.

Em relação especificamente à escrita, é importante considerar a relação entre a fala e a escrita (KOCH e ELIAS, 2017). Considerando que todo texto é resultado de uma coprodução interativa, o que distingue o texto escrito do falado é a forma como tal coprodução se realiza. De acordo com a concepção 
sociointeracionista, o leitor é considerado na produção textual em uma relação “ideal”, como um modelo imaginado, não há uma participação ativa e direta deste no momento da elaboração linguística do texto, em função do distanciamento entre escritor e leitor. O contexto de produção e de recepção não coincidem como na fala e por isso o produtor do texto tem mais tempo para o planejamento, execução e até revisão antes da enunciação. Fala e escrita são consideradas então duas modalidades da língua. Utilizam o mesmo sistema linguístico, mas possuem características próprias. Porém, apesar de serem diferentes, a fala e a escrita não devem ser compreendidas como dicotômicas, e sim como um continuum tipológico das práticas sociais. Para situar as produções textuais ao longo desse contínuo, devemos considerar não só o critério do meio oral ou escrito, mas também a distância (física, temporal, social, etc.) e o envolvimento dos interlocutores. Assim, em um dos polos podemos pensar na conversa informal face a face e no outro a escrita de textos acadêmicos, por exemplo. Entre estes, podemos pensar em textos escritos mais próximos da fala, como bilhetes, ou textos orais mais próximos de textos escritos, por exemplo conferências. É importante considerar semelhanças e diferenças entre textos escritos e orais para o ensino e aprendizagem da escrita, pois na aquisição da escrita é comum a criança transpor para o papel marcas da oralidade, como repetições, uso de organizadores textuais típicos da fala, ausência de referentes e justaposição de enunciados sem conexão explícita. Com o amadurecimento e uso da linguagem escrita, aos poucos a criança vai percebendo as especificidades do texto escrito e se tornando capaz de utilizar de forma adequada os recursos próprios desta modalidade. Temos interesse em pensar como a escrita ocorre nas aulas de Ciências, isto é, de que forma a fala e a escrita se relacionam nesse espaço-tempo da escola.

Assim como para a leitura, na atividade de produção textual o autor precisa mobilizar seus sistemas de conhecimentos sobre os componentes da situação comunicativa. O conhecimento linguístico na escrita é ativado para uso correto da ortografia, das regras gramaticais e do léxico da língua. O enciclopédico é utilizado para acessar informações sobre o mundo que temos armazenadas em nossa memória, a partir de coisas que lemos ou ouvimos ou ainda que vivenciamos e experimentamos. O escritor usa esses conhecimentos para produzir o texto e supõe que façam parte também da memória do leitor. Na escrita, o conhecimento interacional configura a intenção ou propósito do escritor com o texto, ajuda a 
selecionar e adequar a quantidade de informação necessária para situação comunicativa, possibilita a escolha da variante linguística e do gênero discursivo condizente à interação e assegura o uso de sinais e apoios textuais pelo escritor, buscando induzir a criação de sentidos pelo leitor. É possível perceber que os conhecimentos acessados para compreensão e para produção textual cumprem funções relacionadas, mostrando como as atividades de leitura e escrita estão intimamente conectadas, como partes da mesma interação social. Além destes, a escrita ativa um outro sistema de conhecimento, o conhecimento de textos, que pode também ser compreendido como um tipo de conhecimento interacional. $\mathrm{Na}$ produção textual, o escritor acessa "modelos" de textos que possui de práticas comunicativas anteriores, considerando seus modos de organização, aspectos do conteúdo, estilo, função e suporte de veiculação (KOCH e ELIAS, 2017). Nesse sentido, o conhecimento textual se assemelha ao conhecimento interacional ao resgatar "modelos" de textos ou gêneros adequados a cada situação de interação. O conhecimento textual também se relaciona à produção de um texto imbricado a outro texto, dentro do princípio de intertextualidade. Em relação a esse princípio, destaco que toda produção textual é de alguma forma intertextual, já que - como todo discurso - será sempre uma resposta a outro texto e gerará textos como respostas. No entanto, dependendo de seus conhecimentos e objetivos, o produtor poderá manusear com mais ou menos consciência outros textos para compor o seu próprio, servindo melhor ao seu propósito comunicativo. Nesse sentido, Koch e Elias (2017) chamam atenção para como nos processos de ensino e aprendizagem da produção escrita é fundamental considerar os aspectos de intertextualidade.

Para ativar os sistemas de conhecimentos na produção textual, o escritor utiliza variadas estratégias sócio-cognitivas. Essas estratégias não são exatamente as mesmas que as usadas para a atividade de leitura, embora se aproximem e coincidam muitas vezes, visto que a leitura e a escrita possuem uma relação híbrida, afinal todo produtor textual é também um leitor. Estratégias mais específicas da escrita incluem a seleção, a organização e o desenvolvimento das ideias, de modo a garantir a continuidade do tema e sua progressão; o balanceamento entre informações explícitas e implícitas, entre informações consideradas dadas e novas informações trazidas para interação; e também a revisão da escrita ao longo de todo o processo, guiados pelo objetivo da escrita e pela interação pretendida com o leitor. Todas essas são estratégias que usamos para tentar garantir os sentidos desejados 
na interação com o leitor do texto, considerando que, uma vez finalizado, o texto escrito ganha independência do seu autor. Investigamos como essas estratégias são mobilizadas na produção de textos nas aulas de Ciências.

Da mesma maneira que na leitura, a produção do sentido do texto dependerá do contexto da interação, que inclui aspectos semânticos, estratégias utilizadas pelo escritor, conhecimentos compartilhados entre o leitor e o escritor, aspectos sóciopolíticos culturais, o propósito da comunicação, o local onde acontece e os papéis socialmente assumidos pelos interlocutores (contexto, situação imediata, situação mediata e contextos sócio-cognitivos dos interlocutores). Refletindo especificamente sobre a consideração do contexto na modalidade da escrita, Koch e Elias (2017) colocam que para desenvolver bem uma produção textual, é especialmente necessário levar em conta os aspectos contextuais.

\section{[...] ao produzir um texto, o produtor estará focalizando sua atenção em propriedades específicas da situação, as quais devem ser relevantes para propiciar ao leitor pistas para uma interpretação adequada tanto do significado/ referente quanto das intenções/objetivos pragmáticos de quem o produziu (KOCH e ELIAS, 2017, pg. 82).}

Os componentes do contexto intervêm na produção textual na forma de modelos cognitivos, que incluem um conjunto de suposições levantadas pelo sujeito-produtor, considerando pressuposições sobre os leitores e seus conhecimentos. O contexto condiciona e transforma o discurso produzido, orienta a produção e é configurado e reconfigurado ao longo do curso da interação. $\mathrm{O}$ produtor textual utiliza fatores de contextualização que servem para ancorar o texto a determinada situação comunicativa e o tornar coerente. Exemplos de fatores de contextualização propriamente ditos são data, local, assinatura, elementos gráficos que aparecem no texto e o suporte que o veicula. Fatores de contextualização prospectivos são aqueles que permitem criar expectativas sobre o teor do texto, como título, tema, autor, etc. O título serve de fio condutor para as inferências que o leitor irá fazer. Ele poderá ativar na memória do leitor os conjuntos de conhecimentos necessários para compreensão do texto, ajudar o leitor a levantar hipóteses, testadas ao $\log$ o da leitura, entre outros. O tema do texto é um fator de contextualização através da focalização. Na focalização, os autores se concentram apenas em uma parte de seus conhecimentos, com perspectiva na interação esperada. Ela mantém a atenção do escritor no tópico a ser desenvolvido, contribuindo para a coerência textual. Diferenças de focalizações do autor e do 
leitor podem trazer dificuldades de interação e de construção de sentido para o texto (KOCH e ELIAS, 2017).

Após refletir sobre linguagem, e mais especificamente, sobre leitura e escrita na perspectiva sócio-interacionaista, passamos agora a delinear os referenciais teórico-metodológicos que trazemos do campo de pesquisa do ensino de Ciências. Como investigamos relações entre a linguagem escrita e processos de ensino e aprendizagem em aulas de Ciências, pareceu-nos importante que, além de refletir sobre leitura e escrita, buscássemos contribuições de autores da área da educação em Ciências.

\section{2. \\ Disciplina escolar Ciências}

Reflexões sobre linguagem representam um importante tema de investigação do campo de pesquisa do ensino de Ciências. Variadas questões articulando estudos da linguagem e educação científica têm sido investigadas (FLÔR, 2011). Nossa pesquisa também está inserida nessa articulação, visto que estudamos relações entre o ensino de Ciências e o acesso à linguagem escrita. Olhamos para as especificidades das atividades pedagógicas da disciplina escolar Ciências e buscamos compreender como podem contribuir para processos de ensino-aprendizagem de leitura e de escrita.

Sutton (2003) trouxe contribuições importantes para o estudo da linguagem no ensino das ciências. $O$ autor discute que pesquisas sobre argumentação científica, ao longo da história, mostram que a produção de novos conhecimentos científicos é sempre acompanhada do desenvolvimento de uma nova linguagem e de novos procedimentos investigativos. Nesse sentido, o autor coloca que se visamos ensinar aos estudantes sobre a elaboração dos conhecimentos científicos, precisamos nos concentrar na linguagem científica e na discussão de experimentos. Para ele, os professores de disciplinas escolares científicas deveriam ser professores de linguagens das ciências, que surgiram nas variadas áreas científicas e hoje permeiam nossas práticas sociais. Mortimer et al (1998) também traz reflexões importantes em sua pesquisa sobre o uso da linguagem científica por estudantes em provas para o ingresso em uma universidade. Nesse estudo, diferencia esse tipo de linguagem da linguagem comum. De acordo com o autor, a linguagem científica 
possui características de estruturação próprias, que os estudantes vão se apropriando nos processos de ensino-aprendizagem. Essas características se referem principalmente à nominalização de verbos na descrição de fenômenos, à grande densidade lexical e à ausência de narradores na explicação de processos científicos. Construindo uma articulação das reflexões destes autores com a perspectiva bakhtiniana, entendemos que os conhecimentos científicos se desenvolvem em campos sociais que vão amadurecendo e se distinguindo ao longo do tempo; junto com eles, a linguagem também vai se modificando, criando novos conteúdos temáticos e gêneros discursivos. Em associação ao tema da nossa investigação, questionamos como os gêneros científicos dialogam com a escola. Estudamos que características da linguagem científica aparecem nas aulas de Ciências e como se relacionam com processos de leitura e de escrita dos estudantes.

Destacamos que a linguagem científica e a linguagem das aulas de Ciências são diferentes. Ou seja, não há uma transferência direta da linguagem dos campos científicos para a linguagem da escola, visto que são concebidas em campos sociais distintos. Em uma perspectiva bakhtiniana, compreende-se que o caráter e as formas de uso da linguagem diferem com os campos das atividades humanas. Os enunciados proferidos pelos integrantes desse ou daquele campo refletem suas condições específicas e finalidades. Assim, a linguagem da ciência e do ensino de Ciências se diferenciam. Reconhecemos a escola como um campo social desenvolvido e, por isso, com linguagem própria e a formação de gêneros discursivos particulares. O sociólogo da educação Lahire (2004) reconhece essa especificidade, ao mencionar uma escrita escolar específica dessa instituição.

Afirmamos que características específicas da linguagem se articulam à produção de conhecimentos próprios da escola. Teorizações importantes do campo da educação reconhecem especificidades do conhecimento escolar e do discurso pedagógico em relação a outras formas de conhecimento e discurso, especialmente do conhecimento e do discurso científico (LOPES e MACEDO, 2011). Esses estudos assumem que transformações do conhecimento científico ocorrem para fins de ensino, de maneira que a pedagogização do conhecimento produz um conteúdo específico da escola e um discurso pedagógico próprio, que constituem o conhecimento escolar e a linguagem que circula na escola. Tais transformações ocorrem devido à diferença epistemológica entre o conhecimento escolar e o conhecimento científico, determinada pelas distintas finalidades sociais 
das instituições produtoras do conhecimento científico e das conferidas pela sociedade à escola. Na instituição escolar, a organização dos conhecimentos é pensada de forma que possam ser mediados pedagogicamente, ou seja, os mesmos são transformados para que participem dos processos de ensino-aprendizagem. Lopes (1997) traz reflexões sobre essa mediação pedagógica, considerando os embates e conflitos que ocorrem entre as diferentes instâncias e atores no processo de transformação dos conhecimentos de um âmbito para o outro. Nesse sentido, define a mediação pedagógica como um "processo de constituição de uma realidade através de mediações contraditórias, de relações complexas, não imediatas, com um profundo sentido de dialogia" (LOPES, 1997, pg. 564). Aqui podemos fazer uma articulação com o sentido de dialogismo trazido por Bakhtin, ao considerarmos que esses conhecimentos, como discurso, são constituídos por diálogos estabelecidos em diferentes instâncias sociais e que passam a fazer parte da cadeia discursiva da escola, sendo ressignificados nesse processo.

Gomes et al (2013), no estudo de conhecimentos ecológicos em livros didáticos de Ciências do período de 1970 a 2000, discutem que no processo de transformação dos conhecimentos que origina os conhecimentos escolares, alguns saberes são valorizados e outros são marginalizados. De acordo com as autoras, as contradições do conhecimento escolar surgem principalmente porque o objetivo central de ensino do conhecimento científico é atravessado pelos conhecimentos cotidianos que aparecem na escola. "Os processos de elaboração do saber escolar mesclam os saberes científico e cotidiano, como se fossem um só, mascarando as diferenças entre os dois" (GOMES, 2008, pg. 18). Cabe perguntar de que forma isso acontece nas atividades de leitura e/ou escrita das aulas de Ciências. Será que os saberes cotidianos e científicos são mesclados nessas atividades? De que forma?

O conhecimento ensinado na escola pode ser organizado para fins pedagógicos de várias maneiras. Há atualmente no Brasil, por exemplo, algumas tentativas de constituir instituições escolares com propostas que se diferenciem de como a escola tem sido predominantemente organizada nos últimos anos ${ }^{11}$. No

\footnotetext{
${ }^{11}$ O Ministério da Educação (MEC) no final de 2015 criou um projeto para reconhecer propostas que denominou de inovadoras para a organização escolar. Muitas dessas propostas tentavam romper a ideia de organização do conhecimento escolar na forma de disciplinas. O MEC identificou 40 iniciativas em todo Brasil (Disponível em http://criatividade.mec.gov.br/mapa-da-inovacao). É interessante também o trabalho de Moreira (2000) que traz uma análise de propostas curriculares alternativas que surgiram em diferentes estados e municípios do Brasil nos anos de 1980 e 1990.
} 
entanto, apesar dessas tentativas de inovações, os conteúdos de ensino foram e continuam sendo hegemonicamente organizados nas escolas na forma de disciplinas escolares. Nesse contexto, pesquisas sobre as disciplinas escolares são ainda fundamentais, como a que realizamos, especificamente, sobre a disciplina escolar Ciências.

De acordo com Lopes e Macedo (2011), a organização disciplinar pode ser considerada uma tecnologia de organização e controle de saberes, sujeitos, espaços e tempos em uma escola.

Trata-se de uma sistemática de organização do trabalho pedagógico que se expressa em um quadro de horário, no qual temos um professor designado para uma turma, em um dado horário e em determinado espaço, para ministrar um conjunto de conteúdos previamente definidos no currículo (LOPES e MACEDO, 2011, pg. 107).

Tal tecnologia surgiu junto às primeiras tentativas de escolarização de massas no século XIX e desde então tem merecido atenção da pesquisa em educação. Nesse contexto, diferentes posições epistemológicas sobre disciplinas escolares têm surgido, relacionadas a perspectivas distintas de conhecimento e, basicamente, sobre o entendimento de como o conteúdo disciplinar é construído e como se transforma ao longo do tempo. Na presente pesquisa, me baseio no enfoque sócio-histórico das disciplinas escolares, principalmente a partir de Goodson (1995, 1997 e 2001).

\subsection{1. Enfoque sócio-histórico da disciplina escolar Ciências}

Lopes e Macedo (2011), em articulação com a teoria de Goodson, colocam que as disciplinas escolares possuem uma constituição epistemológica, social e histórica distinta das disciplinas científicas. Assim como os conhecimentos científicos e escolares se diferenciam, também o fazem as disciplinas acadêmicas e escolares. Não é um determinado campo acadêmico que confere à disciplina escolar os critérios para a seleção de seus conteúdos e métodos ou para a definição das concepções de ciência e de conhecimento que a constituem. Há muitos outros fatores culturais, sociais, econômicos e políticos das comunidades científicas, das instâncias de produção de materiais didáticos, do governo, das instituições escolares, da vida dos professores e alunos, entre outros contextos, que influenciam 
na constituição e trajetória das disciplinas escolares. Em meio a relações de poder, os atores envolvidos na comunidade disciplinar empregam recursos ideológicos e materiais para desenvolverem seus objetivos individuais e coletivos. Nessa disputa, as disciplinas se formam e se constituem como "amálgamas mutáveis de subgrupos e tradições" (LOPES e MACEDO, 2011, pg. 119). Mutáveis porque no interior das disciplinas escolares, há sempre uma tensão colocada entre estabilidade e mudança nos currículos estabilizados (GOODSON, 2001). Isso acontece porque os atores envolvidos nas comunidades disciplinares se organizam e atuam social e politicamente nas disciplinas escolares e, na disputa por status e recursos, são influenciadas por atores externos, que muitas vezes não compartilham das mesmas ideias, valores e interesses entre si e nem com a comunidade disciplinar. Assim, as possibilidades de mudanças podem ocorrer em uma esfera e não na outra. Esses grupos e subgrupos que influenciam as disciplinas estão em múltiplos e constantes conflitos. Tais divergências acabam levando à estabilidade do currículo, e à falsa naturalização dos conteúdos e métodos das disciplinas. As atividades pedagógicas que observamos nas aulas de Ciências na nossa investigação, com seus conteúdos e métodos, são resultados da estabilidade do currículo dessa disciplina. A mudança curricular ocorrerá apenas quando, em meio a conflitos, surjam interesses que sejam legitimados nas relações entre os grupos que constituem a disciplina e os fatores sociais e culturais externos a ela.

\footnotetext{
A mudança curricular depende de que as estruturas criadas e mantidas pelos professores nos contextos disciplinares encontrem apoio em significados culturais e ideológicos para um público mais amplo, na medida em que essas mudanças dependem de apoio externo. Ferreira et al (2001, pg. 14).
}

Buscando um diálogo com as teorias bakhtinianas, trazemos reflexões sobre como essas mudanças se articulam também à linguagem. Novos discursos vão sendo produzidos e legitimados no interior das disciplinas, até o momento no qual as mudanças são possíveis.

A investigação que realizamos teve como objeto a disciplina escolar Ciências. O estudo da educação científica é bastante desenvolvido no campo de investigações da história do currículo. Recuperamos aqui algumas pesquisas importantes mencionadas por Goodson para compreender as diferentes tradições que fazem parte da disciplina escolar Ciências (GOODSON, 1997 e 2001). 
Estudos mostram que a disciplina Ciências só atingiu destaque no currículo da escola secundária da Grã-Bretanha em meados do século XIX, após intensa luta política (GOODSON, 1997). O trabalho de Ball (1964 apud GOODSON, 1997) remete para as origens do ensino de Ciências nas escolas primárias inglesas em iniciativas do começo do século XIX. As Ciências foram inseridas como lições práticas de hábitos de observação, descrição e julgamento da natureza e da arte, e não com o objetivo de discussão e compreensão de modelos científicos. Goodson dialoga com Layton (1973 apud GOODSON, 1997) para discutir a evolução dessa disciplina ao longo do tempo. Em meados do século XIX, começam os planejamentos curriculares para ensinar a ciência das coisas comuns no currículo estatal escolar inglês. Essa iniciativa recebeu recursos governamentais para aquisição de equipamentos para as escolas, para redação de manuais escolares e para organização de uma escola de formação de professores. Com a sua aplicação e fortalecimento, o currículo ciências das coisas comuns resolveu alguns dos principais problemas de ensino de ciências em uma escola de massas, se tornando uma iniciativa bem-sucedida e cativante para os estudantes da época. Porém, ao longo do tempo, os recursos foram reduzidos e o ciências das coisas comuns foi abandonado. Para os pesquisadores, isso aconteceu porque esse currículo desafiava a ordem social, ao ensinar Ciências aos excluídos historicamente. Dessa forma, houve uma reação de classes superiores, representada nos editoriais de jornais da época, que defendiam o fim da educação científica na escola primária para as classes baixas e a substituição do currículo das ciências das coisas comuns por uma versão de ciência pura e abstrata, estimulada pelo desenvolvimento de laboratórios de pesquisa no ensino superior e uma nova forma de educação científica nas universidades. Criou-se a ideia de que "uma ciência laboratorial pura" deveria dominar o currículo do ensino de Ciências, defendida especialmente nas universidades. Assim, a ciência ensinada nas escolas passou ao controle das universidades e o discurso colocado foi reduzido à abstração excessiva, fora do domínio da linguagem das pessoas comuns. "Surgia agora uma ciência que estava ligada à elite universitária, uma classe predominantemente alta, uma ciência feita à imagem e linguagem dessa elite e perfeita para patrocinar os seus interesses sociais" (GOODSON, 1997, p. 62). A partir desse momento, a disciplina voltou a ganhar apoio governamental e se fortaleceu no currículo escolar secundário inglês. Estudos no Canadá também mostraram que a disciplina Ciências nesse país mudou 
gradualmente de um ensino prático e de estudo da natureza, com objetivos pedagógicos e utilitários, para uma ciência pura acadêmica, que atingiu elevado estatuto, paralelamente ao desenvolvimento das universidades (TOMKINS, 1986 apud GOODSON, 1997).

Baseado em Layton (1973 apud GOODSON, 1997), Goodson apresenta um modelo explicativo das mudanças que as disciplinas escolares vão sofrendo com o passar do tempo. De acordo com esse modelo, as disciplinas evoluem de objetivos pedagógicos e utilitários para uma comunidade que define a disciplina escolar como uma disciplina acadêmica, ligada à universidade. Goodson (2001) discute que esse padrão afasta as disciplinas da educação de massas, ligada à linguagem comum e aos interesses dos alunos.

Como mostra o caso das ciências das coisas comuns, são os conflitos por recursos, status e territórios que levam às mudanças nas disciplinas escolares. As disciplinas são inseridas no currículo com status inferior, com argumentos de pertinência e utilidade para a vida dos estudantes, e sem dependerem de professores especialistas. São constituídas por conteúdos que fazem sentido no cotidiano dos alunos e que se relacionam à formação profissional ou vocacional. A partir de então, começa a se estabelecer uma certa tradição acadêmica para a disciplina escolar e inicia-se o processo de formação de professores especialistas. A legitimidade da disciplina se estabelece não mais apenas pela sua utilidade, mas também a partir de seu status acadêmico. Nesse processo, a disciplina vai se afastando do contexto dos alunos e a seleção e organização curricular começam a funcionar de acordo com uma lógica interna da própria disciplina. Chegam então ao terceiro estágio, no qual a disciplina já possui um conjunto de regras e valores estabelecidos e um corpo de professores especialistas treinados. Os alunos passam a se inserir em uma tradição escolar valorizada principalmente pelo seu status acadêmico. Nesse estágio, considera-se que a disciplina escolar está consolidada no currículo.

Em síntese, haveria um movimento geral das disciplinas escolares: a introdução de uma disciplina no currículo se relaciona a finalidades utilitárias e pedagógicas, mas sua consolidação depende da vinculação a uma tradição acadêmica. Nesse modelo, a tradição curricular acadêmica se relaciona mais aos saberes de referência da disciplina e busca influenciar na maneira de pensar e agir dos estudantes de acordo com determinada disciplina acadêmica ou científica. $\mathrm{Na}$ disciplina Ciências, corresponderia aos processos de ensino e aprendizagem 
associados aos conhecimentos da Biologia, da Física ou da Química. Já as tradições (ou finalidades) utilitárias referem-se ao conhecimento prático de baixo status, relacionados a habilidades básicas usadas no trabalho de uma forma geral e aos conhecimentos considerados necessários à vida prática cotidiana. São, por exemplo, processos de ensino e aprendizagem que procuram, nas aulas de Ciências, instituir hábitos de higiene. Por fim, as finalidades pedagógicas seriam aquelas que aparecem no currículo associadas à ênfase nos processos de como as crianças aprendem. Em diálogo com a perspectiva de estudos da linguagem, acreditamos que ao longo desse caminho a linguagem vai também se modificando. A vinculação às disciplinas acadêmicas provavelmente aproxima os discursos pedagógicos da linguagem científica, isto é, de gêneros discursivos próprios dos campos científicos, complexificando a linguagem das aulas, cada vez mais distante da linguagem comum.

Muitos estudos sócio-históricos sobre o currículo da disciplina escolar Ciências têm sido desenvolvidos no Brasil, a partir das ideias de Goodson. Tais pesquisas buscam entender estabilidades e mudanças da disciplina Ciências em variados contextos. Lopes (2007), por exemplo, analisou a trajetória da disciplina escolar Ciências no Colégio de Aplicação da UFRJ de 1969 até 1998. Para o estudo, a autora utilizou como fontes depoimentos de professores, diretores, ex-professores e ex-diretores da escola, além de documentos escolares como planos de aula, materiais didáticos, planejamentos, livros utilizados, relatórios, entre outros. Os resultados mostraram que a disciplina Ciências no Colégio de Aplicação se desenvolveu em meio a conflitos relacionados às diferentes finalidades sociais reconhecidas pelos atores da escola, tais como a formação de professores e a aprovação nos vestibulares. O CAp/UFRJ mistura características da ação institucional (práticas experimentais) com características que reforçam sua subordinação a definições oficiais externas. A autora destaca que "a história do ensino de ciências no CAp UFRJ vem mesclando, de forma não linear, tradições utilitárias, pedagógicas e acadêmicas" (LOPES, 2007, pg. 1). Mas, de maneira geral, o foco nas tradições acadêmicas acentua-se com o passar dos anos, valorizado pela entrada de novos professores com pós-graduação, busca de recursos junto à universidade (UFRJ), aprovação dos estudantes nos vestibulares e saída dos professores de História Natural da escola. Selles e Ferreira (2005), ao estudarem as finalidades da disciplina escolar Biologia no tema da reprodução humana a partir 
da análise de livros didáticos, entendem que este conteúdo de ensino é em alguns momentos mais vinculado a finalidades de natureza acadêmica - como a teoria da evolução biológica e a fisiologia - e em outros se aproxima mais de demandas dos estudantes do ensino médio, como o estudo de métodos de contracepção, por exemplo, em finalidades de caráter utilitário e pedagógico. Argumentam então que as finalidades se misturam de forma dinâmica. Estes estudos questionam a linearidade do modelo de Layton e destacam que há muitas possibilidades para romper esses caminhos, pois nem todas as disciplinas escolares, em diferentes contextos, seguem a mesma trajetória. As autoras trabalham com a ideia de oscilação entre as diferentes tradições dentro das disciplinas escolares. Em nossa investigação, estudamos as atividades das aulas de Ciências e os diálogos estabelecidos, analisando as tradições curriculares às quais se vinculavam. Interessava-nos perceber que tradições curriculares apareciam na disciplina escolar Ciências das escolas municipais do Rio de Janeiro investigadas. Buscamos ainda perceber de que maneira essas tradições influenciavam a linguagem escrita em uso nos processos de leitura e produção textual vivenciados pelos estudantes nas aulas de Ciências.

Ainda em relação aos estudos curriculares, Gomes et al (2013), em estudo já mencionado de análise de livros didáticos de Ciências de 1970-2000, refletem sobre a organização do currículo de Ciências em diferentes enfoques, estruturados a partir dos conteúdos e métodos que formam esses materiais e que refletem reflexões sobre o que e como ensinar. Esses enfoques vêm sendo construídos historicamente pelos grupos sociais envolvidos com a disciplina Ciências desde sua origem no nosso país. Eles se relacionam às tradições curriculares de Goodson. Gomes (2008) identificou esses enfoques nas proposições para o ensino de Ciências que estavam expressas nos textos de apresentação dos livros aos professores e estudantes e nos seus conteúdos de ensino. O primeiro enfoque discutido é o de História natural, caracterizado por visões de ciência relacionadas à descrição detalhada, coleções e classificações dos seres vivos e de outros elementos do mundo natural (não vivos). Apresenta relações com as trajetórias da Zoologia, da Botânica, da Paleontologia, da Mineralogia e da Geologia, que se articulam ao campo extinto da História Natural e às Ciências Biológicas. Nesse sentido, congregam tradições curriculares acadêmicas, relacionadas à visão evolutiva que caracteriza a disciplina científica Ciências Biológicas, e tradições pedagógicas que aparecem na 
valorização de apresentação do mundo natural para as crianças, através das descrições, coleções e classificações. O enfoque Ecologia articula duas perspectivas, uma referenciada nas Ciências Ecológicas, que inclui o ensino de conhecimentos da ecologia de populações e da ecologia de ecossistemas na escola, e assim, reflete tradições acadêmicas da disciplina escolar Ciências. E outra perspectiva relacionada à educação ambiental, com o objetivo de trabalhar na escola reflexões sobre impactos ambientais, se associando também a tradições pedagógicas e utilitárias. A pesquisadora destaca que o enfoque Ecologia e o História natural muitas vezes se sobrepõem, nas reflexões sobre os seres vivos e seus ambientes. O enfoque Ecologia pode se sobrepor também ao enfoque Anatomia, fisiologia e saúde humanas, nas reflexões sobre as consequências dos impactos ambientais para os seres humanos. O enfoque Anatomia, fisiologia $e$ saúde humanas congrega conhecimentos sobre o corpo humano, sobre as causas e sintomas de doenças e aspectos relacionados à preservação da saúde e do bem-estar. Integra finalidades acadêmicas a aspectos pedagógicos e utilitários. A pesquisadora definiu ainda o enfoque Ciência e experimentação, que aparecia em discussões sobre o método científico experimental como característica principal da ciência, tanto para produção do conhecimento (experimentação científica), quanto para aprendizagem (experimentação didática). Se vincula à tradição acadêmica dos métodos de produção do conhecimento científico e à tradição pedagógica, referente a formas de ensino-aprendizagem. Ciência e tecnologia traz visões de ciência associadas à produção tecnológica que influencia na organização social humana, e, nesse sentido mescla tradições acadêmicas e utilitárias. Por fim, há o enfoque Vida cotidiana que diz respeito aos conteúdos e métodos que se relacionam a variados aspectos da vida cotidiana dos alunos, como a vida doméstica e as atividades profissionais, trazendo perspectivas de tradições utilitárias e pedagógicas. Interessou-nos estudar os enfoques curriculares que apareceram nas aulas e materiais observados e articulá-los às atividades de apropriação da linguagem escrita das aulas de Ciências.

A perspectiva sócio-histórica de estudos da disciplina escolar Ciências contribui também para a compreensão das atividades pedagógicas observadas na investigação que realizamos. Apresentamos alguns aspectos breves da história dessa disciplina, para que nos ajudem a perceber como, ao longo do tempo, determinados conteúdos e métodos foram sendo favorecidos e hegemonizados, a 
ponto de aparecerem atualmente nas nossas observações. Não pretendemos nos alongar na história, pois fugiríamos muito do objeto de estudo, apenas buscamos caracterizar mais detalhadamente nosso objeto.

\subsubsection{1. Aspectos históricos da disciplina escolar Ciências no Brasil}

A origem da disciplina escolar Ciências no Brasil remete à Reforma Francisco Campos de 1931. A disciplina Ciências Físicas e Naturais (atualmente denominada Ciências Naturais) foi oficializada ao longo dos debates que culminaram nessa grande reforma educacional nacional. O ensino das ciências já existia, mas com essa reforma passa a fazer parte de um currículo escolar proposto para o sistema de ensino nacional que estava sendo organizado (GOMES, 2008). Desde sua origem, a disciplina Ciências se caracteriza como uma integração de diferentes disciplinas acadêmicas ${ }^{12}$. O princípio integrador se relaciona historicamente, em sua criação, à ideia positivista de um método único comum a todos os campos de produção científica, vigente na época. Além disso, responde a uma atenção aos fins sociais do ensino dos conhecimentos científicos no nível secundário.

A Lei de Diretrizes e Bases da Educação de 1961 estendeu a obrigatoriedade do ensino da disciplina Ciências a todas as séries ginasiais e a partir de 1971, com a Lei número 5.692, Ciências passou a ter caráter obrigatório nas oito séries do primeiro grau. Essa maior valorização do ensino de Ciências foi influenciada pelo cenário internacional da época, caracterizado pela "guerra fria", que trouxe grandes investimentos no ensino das ciências. No Brasil, essa época foi influenciada ainda pela demanda desenvolvimentista que se destacava, determinando a formação profissional obrigatória em um currículo tecnicista, expresso também na Lei 5.692. De acordo com Krasilchik e Marandino (2004) o período caracteriza-se pela contradição entre documentos que valorizavam o ensino de Ciências e o tempo

\footnotetext{
${ }^{12}$ A disciplina Ciências foi formada pela integração de conteúdos da Geologia, Biologia, Física e Química. No entanto, predomina o foco nas Ciências Biológicas, especialmente porque até a Lei de Diretrizes e Bases da Educação de 1996, apenas licenciados em Biologia eram autorizados a ministrar essa disciplina.
} 
reduzido pela força do currículo profissionalizante. O ensino de Ciências resultante dessa contradição era descritivo, segmentado e teórico.

O pressuposto cientificista que dominava os currículos das disciplinas de Ciências começou a ser questionado nas décadas de 1960 e 1970, à medida que a ciência e a tecnologia não davam conta de responder aos problemas sociais e ambientais que estavam sendo reconhecidos no mundo, inclusive no Brasil. Tais problemas apareciam com o modelo desenvolvimentista globalmente hegemônico a partir da segunda metade do século $\mathrm{XX}$, no qual havia um incentivo à industrialização acelerada, ignorando-se os custos sociais e ambientais desse processo. Diversos movimentos sociais surgiram contestando o modelo de desenvolvimento, entre eles os movimentos ambientalistas. De acordo com Gomes (2008), percebe-se que a partir dessa época, os problemas relativos ao meio ambiente e à saúde começaram a ter presença nos currículos de Ciências Naturais, mesmo que abordados em diferentes níveis de profundidade.

É importante destacar que a disciplina Ciências foi marcada também por demandas pedagógicas influenciadas pelo movimento educacional da Escola Nova $^{13}$, no qual a questão pedagógica avançou para reflexões sobre aspectos psicológicos de ensino-aprendizagem, valorizando-se uma participação mais ativa dos estudantes, como discutem Marandino et al (2009). Nesse contexto, a experimentação passou a ser extremamente prestigiada na disciplina Ciências, assim como o ensino por atividades. Nas décadas de 1960 e 1970, muitos materiais foram produzidos com o objetivo de desenvolver atividades didáticas que levassem o aluno a vivenciar o que se denominava método científico, trabalhando de forma a redescobrir conhecimentos das ciências. A ideia de realização de experimentos para o ensino-aprendizagem de Ciências passou a fazer parte da identidade dessa disciplina e a marca até a atualidade (MARANDINO et al, 2009).

A partir da década de 1980, todo esse contexto de questionamento fortalece uma corrente no currículo da disciplina Ciências conhecida como Ciência, Tecnologia e Sociedade (CTS), que enfatiza a importância de trabalhar temas científicos e de tecnologia em diálogo com questões sociais e ambientais.

\footnotetext{
${ }^{13}$ Escola Nova foi um movimento de renovação do ensino especialmente forte na Europa, na América do Norte e no Brasil, na primeira metade do século XX. Suas ideias foram introduzidas no Brasil por Rui Barbosa em 1882, mas somente no século XX que vários educadores desse movimento se destacaram, especialmente após a divulgação do Manifesto dos Pioneiros da Educação Nova em 1932. Entre eles estavam, por exemplo, Anísio Teixeira e Cecília Meireles.
} 
Conteúdos socialmente relevantes passaram a ser mais valorizados, assim como processos pedagógicos de discussão coletiva de temas sociais e ambientais. Nesse sentido, o ensino de Ciências volta a se aproximar de uma finalidade mais utilitária, o que aparece até hoje no currículo, em convívio com enfoques mais acadêmicos e formais do conhecimento científico. Gomes (2008) destaca que a partir de 1970 " $e ́$ possível perceber que as questões cotidianas se fortaleceram como conhecimentos próprios da disciplina Ciências. Entre essas problemáticas cotidianas, aquelas relacionadas às temáticas da saúde, do meio ambiente e da vida doméstica cotidiana são as mais marcantes" (Gomes, 2008, pg. 50).

Por fim, para finalizar a breve discussão sobre a trajetória sócio histórica da disciplina Ciências, destacamos o contexto do sistema educacional atual no Brasil, influenciado por uma agenda mundial de "nova gestão pública" que se espalhou pelo mundo com o acirramento do neoliberalismo nos anos de 1990 e 2000 . Na educação brasileira, a "nova gestão pública" se traduziu na centralidade da avaliação no debate educacional nas duas últimas décadas, balizando políticas públicas centradas no cumprimento de metas (MAGALHÃES DE LIMA, 2014). Tais políticas enfatizam "as avaliações em larga escala de caráter censitário, o uso de exames padronizados, a mensuração de desempenho de aprendizagem, a informação dos resultados, rankings, e recentemente o desenvolvimento de programas de responsabilização com atribuição de consequências simbólicas e materiais, relacionadas ao alcance de metas estabelecidas" (MAGALHÃES DE LIMA, 2014, pg. 2). Em uma interpretação sócio histórica, o sistema educacional e suas políticas são fatores importantes de controle sobre o currículo das disciplinas, seus conteúdos e métodos. Assim, entendemos que esse novo contexto fortalece determinados conteúdos e métodos da disciplina Ciências, enfraquecendo outros. Acredito que nesse processo sejam legitimadas finalidades mais acadêmicas, tornando a disciplina Ciências com mais conteúdos das ciências de referência e distante de aspectos sociais e cotidianos de vida dos alunos, visto que a relação entre ciências e perspectivas culturais, sociais e políticas da sociedade vêm sendo deslegitimadas na prática pedagógica, ao não apareceram nas avaliações em larga escala. Essa lógica avaliativa acaba favorecendo tradições acadêmicas.

Interpretar a história da disciplina escolar Ciências, entendendo como influenciou diferentes tradições de conteúdos e métodos nessa disciplina na atualidade, é importante para investigação realizada no diálogo com o ensino- 
aprendizagem da leitura e da escrita. Será que os diferentes enfoques curriculares possibilitam diferentes estratégias de ensino e aprendizagem de leitura e/ou escrita? Como atividades de leitura e/ou de escrita aparecem nas diferentes tradições da disciplina escolar Ciências? Diferentes finalidades curriculares permitem diferentes formas de ler e/ou escrever? Como as diferentes atividades pedagógicas delineadas ao longo da trajetória da disciplina escolar Ciências influenciam as possibilidades de acesso à linguagem escrita?

Para continuar as reflexões, apresentamos a revisão bibliográfica desenvolvida para a pesquisa, especialmente buscando autores do campo do ensino de Ciências que trazem reflexões sobre linguagem, leitura e/ou escrita.

\section{3. Diálogo com outras pesquisas}

Diversas pesquisas têm sido realizadas na interseção entre linguagem e ensino de ciências, a partir de distintas bases teórico-metodológicas. A fim de construir um panorama de publicações no tema, apresentamos alguns exemplos, enfatizando suas contribuições para a investigação. Para construir essa revisão, primeiramente procuramos publicações que fossem levantamentos de investigações que articulam o campo de pesquisa em ensino de Ciências e questões de linguagem, a partir delas buscamos as principais referências. Reforçamos que essa revisão é apresentada como um panorama, com exemplos dos tipos de pesquisas realizados e não com a pretensão de esgotar as publicações na área. Dentre os exemplos apresentados, enfatizamos primeiramente um grupo de pesquisas que abordam a questão da linguagem no ensino de ciências de forma mais ampla, como Sutton (2003) e Grandi et al (2011). Depois, apresentamos artigos que pensam a questão da linguagem com reflexões sobre argumentação e ensino de Ciências (KUHN, 1993; SANTOS et al, 2001; e COPE et al, 2013). Discutimos então textos que abordam a aplicação e análise de diferentes possibilidades de leitura e escrita em aulas de ciências e trazemos como exemplos Cassiani-Souza e Almeida (2005); Salomão (2005); Giraldi (2010); e Pinheiro (2015). Concluímos a revisão com a abordagem de artigos que constroem uma relação entre letramento científico e leitura e/ou escrita, destacando os artigos de Suisso e Galieta (2015); Soares e Coutinho (2009); e Yamada e Motokane (2013). 
Sutton (2003) defende o professor de ciências como um professor de linguagem. Argumenta que dois entendimentos sobre linguagem aparecem no ensino de Ciências: de um lado, o entendimento de que a linguagem é usada apenas para transmitir ideias preestabelecidas sobre os fenômenos e, de outro, que a linguagem é uma ferramenta interpretativa. De acordo com Sutton, estudos em história da ciência e teorias da argumentação científica mostram que as novas ideias científicas surgem junto e a partir de uma nova linguagem que os cientistas vão criando. As novas formas de observar e interpretar os fenômenos estão estreitamente conectadas com novas formas de falar e escrever sobre eles. Assim, é importante pensar em como a linguagem se coloca na educação científica. Se queremos que os estudantes compreendam como se constrói o conhecimento científico, é fundamental pensar não somente nas observações e experimentos realizados, mas também na linguagem desenvolvida. Ao se omitir o papel que a linguagem representa na construção de conhecimentos em âmbito científico, está se produzindo uma ideia incompleta e equivocada de ciências, a ideia de que a ciência é neutra e a linguagem expressa apenas verdades que são descobertas cientificamente. Estudos sobre a linguagem são fundamentais porque permitem compreender a ciência como uma construção humana. Diversos pesquisadores têm utilizado Sutton como referência. A discussão que esse autor adensou na problematização sobre a linguagem no ensino de ciências é muito relevante para o entendimento de como o conhecimento sobre a linguagem científica oral ou escrita tem aparecido na escola: normalmente apenas como ferramenta para transmissão de verdades estabelecidas e não com um olhar profundo sobre seu desenvolvimento na construção de novos sentidos sobre o mundo.

Grandi et al (2011) discutem a importância do uso de várias linguagens no ensino de ciências para a enculturação científica. Assim como Sutton, entendem que o ensino de ciências traz uma nova linguagem que "deveria significar muito mais do que a aprendizagem de etiquetas para conceitos conhecidos, e sim a aquisição de um novo sistema semântico e de um novo modo de pensar e ver a realidade” (GRANDI et al, 2011, pg. 2). Percebe-se que compreendem a linguagem científica dentro de um sistema cultural específico e diferenciado, a cultura científica. Segundo os autores, a ciência tem uma cultura própria, com suas regras, seus valores e suas linguagens e deve ser ensinada de forma que os alunos, como participantes dessa cultura, possam discutir e compreender os fenômenos 
científicos e tecnológicos. A publicação apresenta uma pesquisa sobre os processos envolvidos na construção de conceitos científicos, realizada a partir da análise das interações discursivas ocorridas na interpretação de um experimento em uma aula de ciências para o terceiro ano do ensino fundamental. Baseados em Roth (2002 apud GRANDI et al, 2011), os pesquisadores colocam que, no processo de aquisição da linguagem científica em aulas experimentais, os alunos normalmente partem de uma linguagem gestual na tentativa de descrever o experimento realizado, entrando inicialmente em contato com os objetos usados e só depois falando sobre os passos que estão reproduzindo. Quando começam a falar do experimento (e não só a demonstrá-lo concretamente), utilizam apenas pronomes demonstrativos e somente depois nomeiam os objetos (primeiro de forma inadequada). Nos últimos momentos, os alunos conseguem descrever sem mais necessitarem reproduzir o experimento, até o ponto em que passam a utilizar uma linguagem mais científica e teórica. Na aula que analisaram, os alunos fizeram um experimento, explicaram-no oralmente e produziram desenhos e textos escritos sobre o que foi realizado. Os resultados mostram que nessa aula foram utilizadas diversas linguagens, como a gestual, a oral, a escrita e a gráfica. O diálogo oral e o escrito se constituíram em atividades complementares e fundamentais. O diálogo oral se destacou para gerar, clarificar, compartilhar e distribuir ideias entre os alunos e a escrita apareceu como instrumento de aprendizagem que realçou a construção pessoal do conhecimento. Tal trabalho pareceu-nos importante para a reflexão sobre o papel da escrita na aprendizagem de ciências e ajuda também a pensar sobre diferentes produções escritas que podem ocorrer nesses espaços.

Investigações que articulam estudos da linguagem e ensino de ciências têm sido desenvolvidas também a partir de análises do uso de argumentação em aulas de ciências. O próprio trabalho já mencionado de Grandi et al (2011) traz uma discussão sobre essa questão na reflexão de como os alunos utilizaram a argumentação para explicarem o experimento realizado. Kuhn (1993), em um trabalho que marcou a origem dessa perspectiva de estudo, propõe contemplar a aprendizagem das ciências como argumentação, e não somente como exploração, experiências e descrição de fenômenos. Ela indica que o desenvolvimento de destrezas argumentativas não tem lugar em todos os contextos escolares e sugere a importância de desenvolver o potencial de argumentação dos alunos. Nessa mesma linha, destacamos o trabalho de Santos et al (2001), autores muito reconhecidos no 
campo de pesquisa no ensino de ciências no Brasil. Nessa publicação defendem a realização de pesquisas e o desenvolvimento de atividades pedagógicas sobre argumentação no ensino de ciências. Mas, diferente de Kuhn, focam na discussão de temas sócio científicos em aulas de ciências. Entendem que a argumentação se relaciona a escolhas individuais e sociais de temas científicos que o exercício da cidadania nos impõe e, nesse sentido, deve ser valorizada no ensino de ciências. Utilizam a perspectiva sociolinguística de Vigotski e a perspectiva dialógica de Bakhtin para refletirem sobre elaboração conceitual e interações discursivas entre professor e alunos em atividades pedagógicas de debate com uso de argumentação. Na publicação, os autores apresentam um estudo de caso desenvolvido em uma escola pública de ensino médio situada na periferia da cidade de Taguatinga Distrito Federal, em uma turma de primeiro ano do ensino médio, na qual foi realizado um debate sobre ciência, religião e magia em aulas de Química. Os resultados indicam que a prática do professor possibilitou a iniciação dos estudantes em um processo de argumentação. Por outro lado, a pesquisa mostrou também que é importante não somente pedir aos alunos que apresentem argumentos, mas também que busquem fazer julgamentos sobre a natureza de seus argumentos. Estudos sobre argumentação e ensino de Ciências têm contribuído no entendimento da não transparência da linguagem e do seu viés político e cultural na construção e uso de conhecimentos científicos.

Cope et al (2013) descrevem um ambiente virtual de aprendizagem que foi desenvolvido para ensino e aprendizagem da argumentação escrita no ensino de ciências e foi utilizado em um projeto piloto com turmas dos anos finais do ensino fundamental de uma escola pública de Nova Iorque, EUA. No artigo, trazem reflexões sobre o discurso próprio da ciência e sobre a natureza da argumentação científica, que envolve afirmação, evidências, contra afirmações, debate e conclusão. No ambiente desenvolvido, essas etapas são realizadas virtualmente pelos alunos, em um debate escrito sobre determinado tema controverso, mediado pelo professor. Os pesquisadores analisaram o debate sobre fracking ${ }^{14}$ realizado

\footnotetext{
${ }^{14}$ Fracking, ou fraturamento hidráulico, consiste em uma técnica desenvolvida para extração de combustíveis de óleo e gás do subsolo terrestre. É a injeção sob alta pressão de água e substâncias químicas dentro do subsolo, de forma a forçar a liberação das moléculas de combustíveis líquidos e gasosos ali armazenados. É uma técnica polêmica, que gera muitos debates sobre seu uso. Os defensores se baseiam nos benefícios econômicos obtidos com a extração dos combustíveis. Os críticos destacam os impactos ambientais associados a essa técnica, tais como a contaminação dos
} 
com as turmas. Os resultados mostraram que o ambiente possibilitou o desenvolvimento da linguagem escrita dos alunos com características bem próximas da linguagem científica, com suas características argumentativas próprias, incluindo a elaboração de resumos, revisões pelo autor, avaliação pelos pares, e, a partir dessas avaliações, a revisão e reescrita do texto (consciência metacognitiva, avaliação formativa e processo colaborativo de dar e receber feedbacks). Trazem contribuições ao articularem a questão da argumentação no ensino de ciências e a escrita. Segundo os autores, a escrita em Ciências envolve uma linguagem argumentativa e demanda desenvolvimento de habilidades cognitivas elaboradas.

Em relação especificamente à leitura e/ou escrita no ensino de ciências, destacamos o texto de Cassiani-Souza e Almeida (2005) que apresenta os resultados de um trabalho com escrita realizado em aulas de ciências no último ano do ensino fundamental em duas escolas públicas do estado de São Paulo. As pesquisadoras analisaram produções escritas realizadas pelos estudantes ao final de uma sequência didática com diferentes atividades pedagógicas sobre o tema Fotossíntese. O objetivo era compreender o funcionamento da escrita quando solicitada em condições diferenciadas das usuais em aulas de ciências. Referenciadas pela teoria da análise do discurso de Eni Orlandi, especialmente a noção de autoria, as autoras defendem abordagens pedagógicas que potencializem o aparecimento de autoria em textos de ciências produzidos pelos alunos. A análise de nove produções escritas dos estudantes na forma de ficção científica, carta ou diário de bordo evidenciou a possibilidade de desenvolvimento de textos mais autorais pelos alunos no ensino de ciências, ao estimularem manifestações de repetição histórica na produção de significados pelos estudantes, isto é, com reelaboração pessoal dos conhecimentos produzidos. Essas autoras têm realizado muitas investigações e orientado muitas pesquisas sobre leitura e escrita no ensino de ciências no Brasil. Sempre na perspectiva da análise de discurso francesa, têm avançado muito no entendimento dos múltiplos sentidos que a linguagem assume no processo de construção de significados pelos alunos e professores, mesmo no ensino de ciências, onde a linguagem científica funciona na tentativa de reduzir as palavras a um significado único. Nessa perspectiva da análise, compreendem a leitura e a escrita como com substâncias tóxicas, poluição sonora, entre outros. 
produções de sujeitos localizados em determinados contextos histórico-culturais, e não simplesmente a decodificação ou produção de símbolos fechados nos textos. É um processo de atribuição e criação de sentidos, de produção de interpretações. As autoras têm contribuído muito para as reflexões sobre propostas pedagógicas que incluem trabalhos textuais de leitura e/ou escrita diferentes do que normalmente acontecem nas aulas de ciências: trabalhos mais abertos e dialógicos. Estabelecemos com elas diálogos importantes, mas, diferente das autoras, buscamos atividades que efetivamente acontecem e não aquelas que idealmente deveriam ou poderiam acontecer nas aulas, como elaboram para esse trabalho.

A pesquisa de doutorado de Giraldi (2010), sob a orientação de CassianiSantos, exemplifica a elaboração de investigações sobre propostas pedagógicas inovadoras, envolvendo a leitura e a escrita no ensino de ciências. Sua pesquisa teve o objetivo de analisar o funcionamento da leitura e da escrita em aulas de ciências, compreendendo em que condições se desenvolvem, o seu papel nas aulas de ciências e de que modo produzem efeitos (de sentidos) no ensino/aprendizagem de ciências. Baseada no referencial teórico-metodológico da análise de discurso da linha francesa, especialmente em textos de Eni Orlandi e Michel Pêcheux, a autora realizou um estudo em colaboração com dois professores de ciências de uma escola pública de Florianópolis. Os professores participaram de um grupo de discussão de um texto com a pesquisadora, que analisou a percepção do sentido de leitura e escrita que possuíam. Depois, realizaram atividades pedagógicas com o tema energia em suas aulas, trabalhando com textos e produções textuais diferenciadas, que envolveram leituras de imagens, leitura e discussão de texto de divulgação científica, debate sobre o tema radioatividade e diferentes produções escritas (textos, histórias de ficção, elaboração de questões, interpretação de uma música). Os resultados indicaram que modificações nas condições de produção de leitura e de escrita podem produzir mudanças no modo como professores e estudantes relacionam-se com textos de ciências, aproximando-se de uma perspectiva de autoria. Tais trabalhos nos ajudaram a refletir sobre possibilidades variadas de atividades com textos nas aulas de ciências, e levaram-nos a questionar como tais variações influenciam nas habilidades de leitura e escrita dos alunos.

Salomão (2005) realizou sua pesquisa de doutorado também sobre o funcionamento da leitura em aulas de ciências. Trabalhando com a ideia de gêneros do discurso em uma abordagem bakhtiniana, sua pesquisa buscou relacionar 
gêneros literários com gêneros científicos, a partir da análise de uma atividade realizada em uma escola pública de Macaé com um texto teatral de Machado de Assis. Tal texto traz temas científicos ligados à Botânica e à própria construção do conhecimento científico ("Lições de Botânica"). A autora buscou entender como os alunos se apropriavam de conteúdos científicos através da interpretação de gêneros literários. Os resultados mostraram o estabelecimento de diálogos pelos alunos entre gêneros científicos e gêneros literários, destacando os processos de produção discursiva através da interação social na escola e um caminho para refletir sobre a aprendizagem de ciências. Seu trabalho destacou o possível papel potencializador do texto literário na aprendizagem de conteúdos científicos no ensino fundamental. Como refletimos sobre a questão dos gêneros do discurso nas aulas de ciências em nossa pesquisa, a investigação de Salomão (2005) foi importante na interpretação de como os diferentes gêneros do discurso interagem e podem juntos potencializar a leitura e escrita dos estudantes.

Pinheiro (2015) se baseou nos estudos das áreas de alfabetização científica e de gêneros de Marcuschi para investigar estratégias de leitura no trabalho com três gêneros que costumam aparecer nas aulas de ciências: mapa, tabela e artigo de divulgação científica. Sua metodologia consistiu na análise das contribuições que diferentes estratégias de leitura podem fornecer aos professores para a efetivação da alfabetização científica nas aulas de ciências. A autora compreende a leitura como um esforço coletivo da escola e, nesse sentido, defende que todas as disciplinas escolares insiram diariamente momentos de leitura de variados gêneros textuais e que os professores planejem diferentes estratégias de leitura para os estudantes. Em relação às aulas de ciências, especificamente, argumenta que é importante uma leitura proficiente de textos com conteúdos de ciência e/ou tecnologia para a alfabetização científica e participação na sociedade. Trabalha com uma perspectiva sociointeracionista de processamento textual, como formas ativas de interação. A pesquisa foi realizada em uma turma de $6^{\circ}$ ano do ensino fundamental de uma escola particular de Ponta Grossa (Paraná) e incluiu a análise da diversidade de gêneros no livro didático de ciências utilizado, observação das aulas de ciências em relação às propostas de leitura conduzidas pela professora, análise de questionário respondido pela professora de ciências sobre atividades de leitura em suas aulas, aplicação de propostas de estratégias de leitura nas aulas de ciências e análise dos trabalhos realizados pelos estudantes. As estratégias de leitura 
levantadas e defendidas pela autora incluem: discussão do objetivo de leitura do texto, identificação do gênero do texto e sua função social junto com os alunos, leitura silenciosa, reconhecimento e discussão das ideias principais do texto, acionamento dos conhecimentos prévios dos estudantes do assunto em questão, reconhecimento do significado dos termos desconhecidos e interpretação do texto, relacionando com situações do cotidiano (quando possível). Os resultados indicam que as estratégias de leitura contribuíram para desenvolver nos estudantes o conhecimento científico e uma leitura mais proficiente. Tal pesquisa trouxe contribuições para minhas reflexões sobre a leitura como processo interativo mediado pelo professor, sobre a possibilidade de formação de leitores proficientes por meio da leitura de diversos gêneros, sobre a relevância do ensino de ciências aliado a variadas estratégias de leitura para aquisição do conhecimento científico e, finalmente, na compreensão da alfabetização científica como potencializadora para uma educação mais comprometida socialmente. Em a nossa pesquisa, essa investigação permite um diálogo interessante ao pensar sobre leitura nas aulas de ciências. Mas, não investiga sua relação com a produção textual e nem como atividades pedagógicas variadas envolvendo leitura e escrita nas aulas de ciências.

Assim como o trabalho de Pinheiro (2015), vários autores do ensino de ciências têm se debruçado sobre a relação entre alfabetização/letramento científico e leitura e/ou escrita nas aulas de Ciências. Como comentado anteriormente, Suisso e Galieta (2015) realizaram um levantamento importante em periódicos nacionais de publicações que traziam esse debate. Verificaram um número baixo de pesquisas e o desenvolvimento de relações que consideraram superficiais entre a leitura e/ou escrita e a alfabetização científica, principalmente por não trazerem questões da especificidade da linguagem nas ciências. Indicam a necessidade de maior rigor teórico quanto aos conceitos envolvidos, para que as pesquisas possam efetivamente contribuir na melhoria do ensino de ciências. Chamam atenção para a necessidade de esclarecimento do sentido de alfabetização/letramento científico trabalhado e de construir reflexões mais profundas sobre linguagem no ensino de ciências para se pensar leitura e escrita.

Um dos trabalhos analisados pelas autoras foi o de Soares e Coutinho (2009). Esses autores examinaram uma atividade de leitura e produção de textos em aulas de Biologia de uma turma de primeiro ano do ensino médio de uma escola da rede privada de Belo Horizonte, MG. Como referenciais teórico/metodológicos, 
utilizaram a abordagem da Psicologia Sociocultural de Vigotski, o Interacionismo Socio-discursivo, a partir de Bronckart e a noção de letramento científico. O Interacionismo Socio-discursivo de Bronckart utilizado (1999 apud SOARES e COUTINHO, 2009) traz uma perspectiva bakhtiniana ao dialogar com a ideia dos conhecimentos humanos como sendo construídos coletivamente através da atividade, que é coletiva, histórica e social e a linguagem como ferramenta cultural que media a produção interativa dessa atividade. Em relação ao letramento científico, Soares e Coutinho (2009) argumentam que aprender ciências implica saber ler, entender e comunicar-se, tanto oralmente, quanto por meio da escrita na linguagem específica desta área. Para isso, é preciso desenvolver habilidades textuais próprias. Além disso, hábitos mentais científicos, como o raciocínio lógico, o entendimento do papel da experiência, a confiança na evidência, a habilidade de pensar criticamente e outros elementos da investigação científica fazem parte desse letramento. A proposta pedagógica realizada pelos pesquisadores com a turma envolveu a leitura de fragmentos de textos originais de Jean Baptiste Lamarck, Charles Robert Darwin e Alfred Russel Wallace, a discussão em grupo dos fragmentos (orientada por questões elaboradas anteriormente), a exposição oral das discussões e a produção de textos antes e após as discussões. Os textos produzidos antes e depois foram comparados com o objetivo de perceber se as discussões trouxeram modificações no letramento científico dos alunos. A análise foi realizada através da observação das características presentes na arquitetura interna dos textos (infraestrutura geral do texto, mecanismos de textualização e mecanismos enunciativos), em categorias desenvolvidas por Bronckart. Os resultados indicaram que as atividades realizadas permitiram a apropriação por parte dos alunos de noções sobre história e filosofia da ciência e contribuíram para o desenvolvimento do letramento científico. Além disso, a comparação das resenhas produzidas por cada aluno evidenciou o papel importante da discussão em grupo de textos e temas científicos no desenvolvimento da escrita e do letramento científico. De acordo com os autores, esses resultados reforçam "a necessidade de os professores de Biologia incluírem atividades de leitura e produção de textos no planejamento de suas aulas" (Soares e Coutinho, 2009, p. 20).

A publicação de Yamada e Motokane (2013) traz também o entendimento de que as formas textuais da ciência são bastante peculiares e distantes da linguagem do nosso cotidiano, de maneira que a alfabetização científica exige o 
desenvolvimento de habilidades de leitura e escrita específicas. Com o intuito de estudar a aquisição da linguagem científica pelos alunos, os autores estudaram o desenvolvimento da escrita de alunos do sexto ano em aulas de uma sequência didática de Ecologia em uma escola pública do interior de São Paulo. A sequência envolveu a leitura de textos, análise de fotos, resolução de situações problema, discussão em grupo e, finalmente, produção textual. Especificamente, analisaram se os alunos se apropriam de discursos alheios, de que maneira isso é feito e a relação disso com a qualidade conceitual das produções escritas. Para tanto, identificaram na produção textual dos alunos marcas do texto lido e da fala da professora, em articulação com análise do conteúdo em relação à correção conceitual científica. O referencial teórico-metodológico utilizado também está em uma perspectiva dialógica de Bakhtin. Dessa forma, compreendem o papel constitutivo da linguagem na cultura e na identidade humana e defendem que o conhecimento se desenvolve, seja ele científico ou não, a partir das interações entre sujeitos, na medida em que há o compartilhamento de experiências entre os pares de uma comunidade e, sendo assim, é socialmente e historicamente construído e validado. Considerando a escrita nesse contexto, o texto não pode ser percebido apenas como consequência de um processo individual, puramente cognitivo ou a elaboração de um conjunto de normas gramaticais. Ao contrário, dada a essência dialógica da linguagem, a interação estabelecida com o outro tem função extremamente relevante na construção de significados textuais. Nesse contexto, investigaram a existência de relações entre as interações (dos alunos com o texto e dos alunos com a professora) e o conteúdo científico da produção dos alunos para tentar compreender como a apropriação das vozes da professora e do texto se reflete na produção escrita do aluno. A análise dos resultados mostra que existem marcas linguísticas aparentes das interações verbais estabelecidas na aula que são expressas nos textos escritos pelos alunos. As relações entre as interações e a qualidade das explicações dos alunos refletem a importância do outro na constituição de um enunciado e, consequentemente, na construção do conhecimento. Como possível aporte para minhas reflexões, a pesquisa traz a colocação das múltiplas vozes que estão envolvidas nas produções textuais que ocorrem nas salas de aula.

Em síntese, muitos estudos discutem a importância da reflexão sobre linguagem na educação em ciências. Trazem contribuições para a compreensão de aspectos relativos à produção de sentidos, construção de autoria e desenvolvimento 
da argumentação nas aulas de ciências. Ajudam a pensar sobre a relevância de propostas diferenciadas de leitura e escrita para o ensino/aprendizagem de temas científicos e, especialmente, para o letramento científico. Abordam inclusive a produção e a interpretação de textos que acontece nas aulas de ciências. No entanto, deixaram uma lacuna na compreensão da relação entre a produção da linguagem escrita que acontece nessas aulas e a produção que ocorre em outros espaços. As pesquisas desenvolvidas focam principalmente nos processos de ensino/aprendizagem de ciências, isto é, analisam a leitura e a escrita, refletindo sobre a importância desses processos para a compreensão de conhecimentos científicos. Não pensam como produções textuais das aulas de ciências dialogam com outras possibilidades de leitura e escrita, mesmo quando o tema não é científico. Assim, não buscaram entender de que maneira o ensino/aprendizagem de ciências pode contribuir na formação geral de leitores e escritores. Além disso, a maior parte dos trabalhos analisados centrou na visão do professor de ciências sobre leitura e escrita e não discutiram a concepção dos alunos sobre leitura e escrita nos espaços das aulas de ciências. Pensando sobre os avanços trazidos pelos estudos destacados e as lacunas encontradas, realizamos a pesquisa relatada, cuja empiria detalhamos melhor no capítulo a seguir. 


\section{3 \\ Estratégias metodológicas: a construção da empiria}

Precisamos, portanto, de formas de expandir o alcance de nosso pensamento, de ver o que mais poderíamos estar pensando e perguntando, de aumentar a capacidade de nossas ideias lidarem com a diversidade do que se passa no mundo (BECKER, 2007, pg. 25)

Neste capítulo discutimos as estratégias metodológicas do estudo e descrevemos a construção do campo empírico, procurando justificar as escolhas feitas. Do ponto de vista epistemológico, trabalhamos com a concepção teóricometodológica da ciência como produto cultural humano, sempre provisório e ideológico. Nesse sentido, o conhecimento é compreendido como um processo incessante de construção, uma busca inesgotável de uma nova interpretação para um fenômeno da realidade. Há várias interpretações possíveis, dependendo das teorias nas quais nos baseamos e das circunstâncias históricas e sociais nas quais estão inseridas. Como parte da cultura humana, a ciência é repleta de subjetividades e fortemente influenciada por valores ideológicos e contextos sociais, políticos e econômicos estabelecidos. Nesse sentido, é importante buscar critérios de objetividade e confiabilidade na construção da pesquisa. Para isso, realizamos a pesquisa utilizando diferentes fontes de investigação, colocando referenciais teórico-metodológicos claros para interpretação dos fenômenos e validando a interpretação através do diálogo com outras pesquisas (PHILIPS e BURBULES, 2000).

Becker (2007) inspirou-nos na reflexão sobre os desafios teóricometodológicos colocados para ciências sociais, especialmente em pesquisas de cunho qualitativo, como a que relatamos aqui. $\mathrm{O}$ autor destaca a importância de nos protegermos de nossas representações iniciais, para que os dados gerados não sejam somente o que esperávamos encontrar, de acordo com nossas ideias preconcebidas, nos impedindo de perceber sentidos e significados diferentes que apareçam. Como, além de pesquisadora, atuamos como professora de Ciências, essa questão foi fundamental ao longo de toda realização da pesquisa. Parece-nos que quanto maior a familiaridade com o objeto de estudo, maior o risco da contaminação pelas ideias iniciais, nesse caso, formuladas pela vivência como profissional da escola. Assim, 
foi importante que a todo tempo fizéssemos questionamentos sobre o que estávamos observando. O projeto piloto realizado na pesquisa contribuiu para reflexões sobre esse aspecto, especialmente ao testar o nosso olhar de pesquisadora para observação de outra realidade escolar, diferente da que vivenciamos como professora.

As questões que guiaram a pesquisa nos levaram a escolher uma abordagem qualitativa para construção dos dados. A perspectiva qualitativa tem sido reconhecida como importante forma de produção de conhecimento no campo de pesquisa em educação, como destacam diferentes publicações sobre o tema (ROLDÃO, 2015; FLICK, 2009; BECKER, 2007; LÜDKE e ANDRÉ, 1986, entre outros). De acordo com Santos (2009), pesquisas qualitativas ajudam a compreender ideologias, representações, motivações, ações, estruturas discursivas dos atores sociais e seus comportamentos. Além disso, auxiliam na interpretação de contextos históricos e sociopolíticos de inserção dos sujeitos e fenômenos sociais estudados. Na pesquisa realizada, como estudamos processos de produção de linguagem e percepção dos sujeitos sobre esses processos, um estudo qualitativo pareceu-nos mais apropriado.

Mais uma vez, destacamos que a utilização de diferentes fontes de dados foi importante para confiabilidade do conhecimento produzido, especialmente pela possibilidade de verificação por comparação e triangulação entre os dados produzidos por fontes diversas, que incluíram: i) discursos de três professoras e estudantes em atividades pedagógicas envolvendo leitura e/ou escrita que aconteceram em aulas de Ciências de turmas do sexto ano do ensino fundamental de três escolas municipais da cidade do Rio de Janeiro; ii) materiais didáticos utilizados nessas aulas; e iii) discursos destas três professoras e estudantes sobre as aulas de Ciências, especialmente em relação à linguagem escrita. As técnicas usadas para investigar tais fontes foram: i) observação com anotações em caderno de campo e audiogravação das aulas de Ciências; ii) análise dos Cadernos Pedagógicos de Ciências do sexto ano dos $3^{\circ}$ e $4^{\circ}$ bimestre de 2016 (COORDENADORIA DE EDUCAÇÃO DO RIO DE JANEIRO, 2016) e de outros materiais didáticos utilizados; e iii) entrevista semi-estruturada com as professoras e grupos de estudantes. A seguir, detalhamos melhor as fontes de investigação e as estratégias metodológicas desenvolvidas para estudá-las. 


\section{1.}

\section{Observação de aulas de ciências}

Para entender as relações entre atividades pedagógicas de aulas de Ciências e a linguagem escrita que circula nesses espaços, foi necessário observar interações concretas que ocorriam no cotidiano escolar. Defendemos que, para interpretar a forma como essas relações se estabelecem, é importante analisar as interações de professores e alunos entre si e com os textos no momento que ocorrem, já que são essas interações que constituem os processos de ensino-aprendizagem. Em uma perspectiva bakhtiniana, estudos da linguagem só são úteis se considerarem o uso da língua na sua concretude. Assim, a principal fonte da investigação foram observações de campo de aulas de Ciências realizadas ao longo do segundo semestre letivo de 2016 (de setembro a dezembro).

$\mathrm{Na}$ trajetória de construção do campo empírico da pesquisa, o primeiro desafio colocado foi em relação à amostragem. Qual seria o número adequado de professores que deveriam ser observados para investigar as práticas pedagógicas propostas em aulas de Ciências? Como fazer a seleção desses sujeitos? Há um número muito grande de escolas na cidade do Rio de Janeiro, com um enorme número de professores de Ciências, com formações diferentes, histórias de vida distintas, conhecimentos variados, atuação profissional em contextos muito heterogêneos, capital cultural e simbólico diversos, etc. Enfim, sujeitos únicos que com certeza interagem e constroem relações pedagógicas distintas umas das outras, elaborando e vivenciando aulas e atividades pedagógicas particulares. Nesse sentido, era importante escolher mais de um professor, para que tivéssemos maior diversidade de atividades pedagógicas para observar, ou seja, um número maior de interações para investigar. Por outro lado, havia um limite de tempo. A metodologia de observação exige uma dedicação intensa e julgamos importante estar com os professores o maior número de aulas de Ciências possível, para conseguir entender melhor o contexto em que as aulas ocorriam, estudar a continuidade das atividades realizadas e observar as interações ao longo do tempo. Além disso, acreditamos que quanto mais frequente fosse a presença da pesquisadora, mais natural ela seria e menos influência teria no comportamento dos estudantes e professores, de forma que pudéssemos efetivamente perceber o que ocorria nas salas de aula. Em síntese, buscávamos uma forma de observação com a maior imersão possível nas aulas. 
Sendo assim, observar um número muito grande de docentes seria muito difícil. No entanto, observar as atividades de um único professor poderia nos trazer poucos dados, sobre uma realidade muito específica, dificultando a geração de conhecimentos e reflexões que pudessem ser úteis para pensar sobre outras realidades. Há aqui a inquietação sobre a investigação que, como coloca Roldão (2015), nos leva "por um lado, a necessidade de responder à singularidade e complexidade dos objetos de estudo e, por outro, o requisito da comunicabilidade e transferibilidade do conhecimento produzido, sobretudo numa área de natureza sócio prática como é a Educação" (ROLDÃO, 2015, pg. 15). Nesse sentido, buscamos o número máximo de docentes que poderíamos acompanhar, considerando o tempo e recursos disponíveis, e a necessidade de acompanhar todas as aulas de Ciências, em uma tensão entre a singularidade e o universalismo, refletido na busca da generalização possível. Decidimos realizar o trabalho de campo com o maior número de docentes possível, de forma que eu pudesse assistir a maior parte de suas aulas de Ciências nas turmas de sexto ano das escolas municipais que atuavam.

A dificuldade colocada a partir daí se relacionava à seleção dos professores a serem observados. Como escolher os docentes a serem acompanhados em um universo tão grande? Como coloca Becker (2007), é preciso reconhecer que "nossas ideias gerais sempre refletem a seleção de casos a partir do universo que poderia ter sido considerado" (BECKER, 2007, pg. 25). Assim, é importante a escolha de casos que possam maximizar a chance de produzirmos dados que permitam a construção de interpretações para nossas questões de pesquisa, ou ainda que "nos façam questionar o que pensamos saber" (BECKER, 2007, pg. 25). Decidimos por uma escolha intencional, não representativa, realizada a partir dos objetivos da pesquisa. Dessa forma, resolvemos selecionar professores de Ciências do sexto ano de acordo com critérios que favorecessem a possibilidade de encontrarmos a realização de atividades pedagógicas envolvendo leitura e escrita nas aulas de Ciências. Nessa escolha, consideramos também que para realização de um estudo de imersão, era fundamental contar com a colaboração dos sujeitos participantes da pesquisa. Para encontrar os professores, entramos em contato com docentes de Prática de Ensino em Biologia de universidades públicas do Rio de Janeiro (Universidade Federal do Rio de Janeiro - UFRJ; Universidade Federal Fluminense - UFF; e Universidade do Estado do Rio de Janeiro - UERJ). Avaliamos que essas 
docentes deviam conhecer professores formados por elas que estavam em atuação na rede municipal e que tinham compromisso com processos de ensinoaprendizagem de seus alunos. A ideia era que as docentes indicassem professores nos quais esse compromisso se destacava de alguma forma. Apostamos que se esse compromisso com o ensino-aprendizagem estava presente na prática pedagógica, a questão da leitura e escrita apareceria em suas aulas. Afinal, como se comprometer em ensinar Ciências sem refletir sobre dificuldades em leitura e/ou escrita? Criamos assim uma forma de seleção por indicações. Recebemos das docentes de Prática de Ensino 12 indicações e entramos em contato virtualmente com esses professores. Explicamos o objetivo da pesquisa e perguntamos sobre a possibilidade de observar as aulas de suas turmas de sexto ano até o final do ano letivo. Além do compromisso ético com o aceite dos professores, clareando os objetivos e procedimentos da pesquisa, precisávamos ainda que as grades de horário das aulas de Ciências das escolas não coincidissem. Conseguimos encontrar três professoras em três escolas de Coordenadorias Regionais de Educação (CRE) diferentes, o que nos trouxe a diversidade procurada, pois além de serem três professoras distintas, atuavam em escolas em contextos bastante diferentes, o que aumentava a chance da observação de atividades pedagógicas de aulas de Ciências com variadas relações com leitura e/ou escrita.

Assim, as observações foram realizadas em aulas de Ciências de três professoras que trabalhavam em turmas de sexto ano do ensino fundamental de três escolas da rede municipal da cidade do Rio de Janeiro. Há diferentes justificativas para a escolha dessa rede. Primeiro, é uma rede de educação pública. Defendemos a realização de pesquisas no ensino público por acreditar que essa é a forma mais democrática de educação. A maior parte das crianças e jovens do nosso país estão na escola pública, com recentes conquistas, como a massificação do acesso na década de 1990, mas também com problemas muito complexos, como a própria dificuldade para o acesso à cultura letrada, conforme destacamos nessa investigação. Em um país de tanta desigualdade como o Brasil, são fundamentais pesquisas que investiguem como podemos atuar para melhoria da educação pública. Justificamos a escolha da rede municipal do Rio de Janeiro por ser esta a maior rede pública municipal de ensino da América Latina. Dados da prefeitura indicam que a rede possui 1.537 unidades escolares, divididas em 1.009 escolas e 528 unidades de educação infantil. O número de professores é de aproximadamente 41 mil e de 
alunos matriculados 655 mil (SECRETARIA MUNICIPAL DE EDUCAÇÃO, ESPORTES E LAZER DO RIO DE JANEIRO, 2017 a). Com uma rede pública dessa extensão, sua escolha se justifica pela diversidade de realidades que a compõem. Propusemos turmas de sexto ano da rede porque essa é a série inicial do segundo segmento do ensino fundamental, na qual dificuldades com leitura e escrita costumam ser bastante significativas. Além disso, geralmente é nesse nível de escolaridade que as crianças começam a ter professores especialistas em cada disciplina escolar, incluindo Ciências. Na Secretaria de Educação do Rio de Janeiro está em implantação o que denominam "sexto ano experimental" desde 2011. Nesse projeto, o sexto ano passa a integrar o primeiro segmento do ensino fundamental, sendo as disciplinas ministradas por um único professor generalista. No ensino regular, as turmas do sexto ano possuem diversos professores especialistas, um para cada disciplina escolar. Como a pesquisa se refere especificamente ao ensino de Ciências e ao trabalho de professores especialistas do segundo segmento, buscamos escolas regulares.

De acordo com os referenciais teórico-metodológicos utilizados nessa investigação, em uma concepção sociointeracionista da linguagem, o texto, como materialização do discurso, é um espaço de interação entre produtores e interlocutores, situados sócio historicamente. Nesse sentido, é fundamental considerar o contexto no qual essa interação ocorre, pois esse também dará sentido ao discurso e ao texto. Segundo Bakhtin-Voloshínov (1990), qualquer aspecto da expressão-enunciação, o que afirmamos que inclui também a enunciação escrita e a interação constituída através dela, será sempre determinado pela situação social mais imediata. Assim, julgamos pertinente apresentar o perfil dos sujeitos envolvidos na pesquisa (professoras e suas turmas) e das escolas estudadas, como fazemos na próxima seção. 


\subsection{1.}

\section{Perfil das professoras, turmas e escolas selecionadas}

A professora Carla ${ }^{15}$ se formou em licenciatura e bacharelado em Ciências Biológicas na UFF em 2005. Por ter se destacado em sua formação inicial, recebeu uma carta da docente de Prática de Ensino em Biologia desta universidade, enaltecendo seu compromisso e recomendando-a como professora. Durante a universidade, recebeu bolsa de iniciação científica ligada a um laboratório de pesquisa em ensino de Biologia e depois outra bolsa de um laboratório de zoologia do Museu Nacional da UFRJ. Foi também monitora de matérias do curso de Ciências Biológicas e da licenciatura. Continuando sua formação, fez mestrado em Zoologia no Programa de Zoologia do Museu Nacional da UFRJ, com conclusão em 2007.

$\mathrm{Na}$ entrevista, Carla descreveu sua trajetória docente a partir do trabalho em pré-vestibulares comunitários, como voluntária, ainda durante a graduação. Atuou como professora de Biologia em um pré-vestibular comunitário coordenado por um professor da UFF em 2002 e 2003. De 2003 a 2007, foi professora de um prévestibular comunitário da escola privada onde tinha estudado em Niterói. Profissionalmente, seu primeiro trabalho foi em uma faculdade privada, paralelamente ao mestrado. Quando terminou o mestrado, começou a estudar e fazer concursos para trabalhar como professora da educação básica. Em 2008, foi aprovada e chamada para ser professora da Secretaria de Educação do município de Friburgo, onde trabalhou até o início de 2011. Também em 2008 começou a trabalhar em uma escola privada em Niterói, onde ficou até o final de 2011. Em 2009, foi também chamada pela Secretaria de Educação do município do Rio de Janeiro, tendo sido aprovada no ano anterior. Ela começou então a trabalhar na Escola 1, onde realizamos o campo empírico em 2016. Em 2011, Carla começou a trabalhar em uma escola da rede de educação do município de Niterói, onde também continuava até 2016. A partir de 2013, assumiu também turmas em uma escola privada de Niterói.

\footnotetext{
15 As professoras foram identificadas com nomes fictícios por uma questão ética, para que suas identidades fossem protegidas como sujeitos da pesquisa. O mesmo vale para as escolas, turmas e estudantes.
} 
Em 2016, a professora morava em Niterói. A Escola 1, onde a pesquisa foi realizada, ficava bem distante da sua residência. Assim, na época do campo empírico, a professora trabalhava em 3 escolas: a Escola 1 (da rede municipal do Rio de Janeiro), uma escola da rede municipal de Niterói e uma escola privada no mesmo município. Semanalmente, ela tinha 31 horas de aula, sem contar tempos de planejamento e avaliação. Refletindo sobre a narrativa de sua trajetória, percebemos que Carla apresentava um forte investimento em sua formação inicial como professora de Biologia, com dedicação e realização de diferentes atividades acadêmicas, tanto no campo da educação, quanto da Biologia, incluindo um mestrado em Zoologia. Começou a dar aulas cedo, ainda como aluna universitária, e em 2016 ocupava grande parte do seu tempo com aulas, em diferentes escolas. Como a realidade de muitos professores no nosso país, Carla dava várias aulas por semana e se dividia entre várias instituições, com uma grande carga de trabalho docente.

A turma 1 da professora Carla, na qual as aulas foram observadas, era uma turma de sexto ano do ensino fundamental que estudava no turno da tarde na Escola 1. Tinham três tempos de aulas de Ciências por semana, que aconteciam às quintasfeiras e às sextas-feiras. Era composta por 34 alunos, 18 meninos e 16 meninas, sendo um aluno de inclusão. A turma possuía 5 alunos repetentes (14\% dos alunos). A turma era em geral frequente, com apenas 5 alunos com percentual de faltas no ano de 2016 superior a $25 \%$ das aulas. O desempenho da turma ${ }^{16}$, de acordo com a professora de Ciências, era mediano, isto é, regular para a maior parte dos alunos, tanto no conceito geral (considerando todas as disciplinas escolares), quanto especificamente nas aulas de Ciências. Os alunos vieram de turmas da própria escola, ou seja, a frequentavam desde o primeiro segmento do ensino fundamental. Durante as observações, percebemos que no geral a turma participava bastante das aulas, dialogando com a professora, fazendo os exercícios propostos e colocando dúvidas. Alguns poucos alunos ficavam a parte do que estava acontecendo e não se envolviam com as propostas. Ainda de acordo com a professora, a maior parte dos alunos da turma viviam nas comunidades de baixa renda do entorno da escola.

\footnotetext{
$16 \mathrm{O}$ desempenho dos estudantes da rede escolar municipal do Rio de Janeiro é dividido nos conceitos: i) de 80 a 100: MB (Muito Bom); ii) de 70 a 79: B (Bom); iii) de 50 a 69: R (Regular); e iv) de 0 a 49: I (Insuficiente). (De acordo com a Resolução SME nº 1010, de 04/03/2009)
} 
A Escola 1 se localiza no bairro do Catumbi, um dos mais antigos da cidade, na zona central do Rio de Janeiro ( $\left.1^{\mathrm{a}} \mathrm{CRE}\right)$. Datado da época colonial, até o início do século XX o Catumbi era considerado uma região nobre da cidade, com sobrados, chácaras e grandes casas de classe média. A partir do século XX, com a expansão da malha urbana, o perfil de ocupação do bairro começou a mudar. A sua população, de aproximadamente 12.556 habitantes em 2010, vivia em grande parte em comunidades de baixa renda. Atualmente, o local se caracteriza por um baixo índice de desenvolvimento social ${ }^{17}$ (IDS de 0,558 em uma escala até 1 , sendo o $100^{\circ}$ em um total de 158 bairros da cidade do Rio de Janeiro) (CAVALLIERI e LOPES, 2008) e um alto índice de violência, relacionada principalmente ao tráfico de drogas. Devido a sua localização, a Escola 1 participava do Programa "Escolas do Amanhã" em 2016, criado pela Secretaria de Educação especialmente para escolas em áreas conflagradas da cidade, consideradas vulneráveis socialmente ${ }^{18}$.

O contexto de violência influenciava o cotidiano da Escola 1. Durante a realização do campo de pesquisa, em várias aulas os alunos comentaram sobre tiroteios e disputas de facções do tráfico de drogas nos locais onde vivem. Em mais de uma ocasião, alunos justificaram a falta em aulas anteriores pelas dificuldades em percorrer o caminho até a escola devido à violência, como falou para professora uma das estudantes em um dia de aula "o pessoal da Coroa não tá deixando as criança descer pra escola.". Em três dias marcados para observação, não pudemos ir à escola, pois as aulas foram canceladas devido a tiroteios. Em um dos dias de observação, no qual eu estava presente na escola (dia 10 de novembro de 2016), houve troca de tiros na rua em frente e na comunidade de baixa renda atrás da

17 O Índice de Desenvolvimento Social (IDS) mencionado foi inspirado no Índice de Desenvolvimento Humano (IDH) calculado pela Organização das Nações Unidas (ONU) para comparação entre países do mundo. A finalidade do IDS é medir o grau de desenvolvimento social de uma determinada área geográfica em comparação com outras de mesma natureza. Para composição do índice, foram utilizados 10 indicadores, construídos a partir de variáveis do Censo Demográfico 2000 do IBGE. Tais indicadores cobrem quatro grandes dimensões de análise: acesso ao saneamento básico, qualidade habitacional, grau de escolaridade e disponibilidade de renda (CAVALLIERI e LOPES, 2008).

18 O Programa "Escolas do Amanhã" abarca 155 escolas. Foi criado em 2009 pela Secretaria Municipal de Educação do Rio de Janeiro e de 2010 até o final de 2016 desenvolvido em parceria com a UNESCO. O objetivo central é garantir condições de ensino-aprendizagem em escolas que estão em locais da cidade do Rio de Janeiro conflagrados por altos índices de violência, buscando a melhoria do desempenho escolar e a redução das taxas de abandono e evasão. Tem como metas ações de fortalecimento de gestão, melhoria de infraestrutura e desenvolvimento de projetos, buscando envolvimento das famílias e mediação de conflitos (SECRETARIA MUNICIPAL DE EDUCAÇÃO, ESPORTES E LAZER, 2017 b). 
escola; nesse dia, estudantes, professores e funcionários não puderam sair do prédio e tiveram que ficar nas salas de aula, o pátio precisou ser evacuado e chegamos a enfrentar a invasão de traficantes na sala de professores da escola. Durante três dias da semana seguinte, as aulas foram canceladas. Após esse evento, a professora Carla se afastou da escola por problemas emocionais relacionados ao episódio de violência vivenciado. A partir de então, precisamos parar as observações nessa escola.

O prédio da Escola 1 é tombado pelo Instituto de Patrimônio Histórico e Artístico Nacional (IPHAN) e foi construído no início do século XX para abrigar a instituição escolar. Possui dois andares, um grande pátio interno e algumas estruturas anexas. A infraestrutura da escola incluía em 2016: uma quadra de esportes aberta e outra quadra coberta; um laboratório de Ciências com materiais (provenientes de projetos anteriores de parcerias público-privada); um laboratório de informática bem equipado (havia 30 computadores em funcionamento); uma grande sala de leitura; uma sala de vídeo com uma televisão grande de tela plana, aparelho leitor de $\mathrm{DVD}^{19}$, aparelho de som e computador; um ateliê de artes; uma ampla sala de professores com geladeira, filtro, micro-ondas e cafeteira; um refeitório grande com cozinha; 22 salas de aula equipadas com quadro branco, condicionador de ar e projetor; uma sala de recursos para educação especial; e uma área exclusiva para educação infantil. A beleza da arquitetura do prédio e a infraestrutura da escola se opunham à violência do contexto no qual se localiza. Entrevistas com os professores, funcionários e a direção da escola destacaram sua fundação em 1929 como uma das cinco escolas experimentais criadas na reforma anisiana $^{20}$. Ela surgiu como uma escola ginasial, ampliando as séries atendidas ao longo dos anos. Em 2016, havia crianças da educação infantil (a partir de 4 anos) até o $9^{\circ}$ ano do ensino fundamental e alunos em projetos especiais da Secretaria de Educação para aceleração do fluxo escolar, conhecidos como "Acelera" e "Realfabetização"21. Nesse ano, o total de alunos matriculados era de 1.120. A

\footnotetext{
${ }^{19}$ DVD é um acrônico de Digital Video Disc ou Disco Digital de Vídeo em português.

${ }^{20}$ As escolas experimentais foram criadas como parte do projeto pedagógico da gestão de Anísio Teixeira no Departamento de Educação do antigo Distrito Federal na primeira metade dos anos 1930. Algumas tentativas de inovações relacionadas ao movimento da Escola Nova marcaram essas instituições, tais como a educação integral, o Sistema Platoon e o ensino experimental, com métodos mais ativos de ensino-aprendizagem (CHAVES, 2001).

${ }^{21}$ Os projetos "Acelera" e "Realfabetização" foram criados em 2009 a partir de parcerias entre a Secretaria de Educação do Rio de Janeiro e institutos privados com o objetivo de diminuir a distorção
} 
Escola 1 funcionava nos turnos da manhã e da tarde, com turmas diferentes. Acompanhando o cotidiano da escola, percebemos que estavam sendo organizados muitos eventos pela equipe de docentes em trabalho com as turmas, como produção de um jornal, olimpíadas, festival de leitura com as famílias, feira de Ciências e festival de poesia na escola. O currículo era organizado de forma disciplinar, de acordo com o determinado pela Secretaria Municipal de Educação. Em relação à avaliação externa dos anos finais do ensino fundamental da escola, após crescimento do Índice de Desenvolvimento da Educação Básica (IDEB) ${ }^{22}$ de 2010 até 2015, nesse ano, foi de 3,5, abaixo da média estipulada pelo MEC para a escola (que era de 4,4). Assim, em 2016 os professores não receberam bonificação por desempenho. Em 2016, o quadro de professores da escola estava completo, a maioria na categoria de 16 horas semanais de trabalho, como a professora Carla, mas alguns - oriundos dos últimos concursos - trabalhavam 40 horas semanais na escola. Comparecemos à Escola 1 onze dias no total, entre setembro e novembro de 2016, somando 20 tempos de aulas ${ }^{23}$ de Ciências observados.

Além das aulas da professora Carla, observamos as aulas de Ciências da professora Valéria na turma 2 da Escola 2. Em sua entrevista, Valéria contou que se formou em licenciatura em Ciências Biológicas na UFRJ em 2007 e no bacharelado em Ecologia em 2009. Durante a graduação, teve bolsa de Iniciação Científica no Instituto de Microbiologia da UFRJ, bolsa de monitoria nas disciplinas de Didática Especial das Ciências Biológicas I e II, participou de um

idade-série nas escolas. No "Realfabetização" alunos com dificuldades de aprendizagem, especialmente em relação à alfabetização, são encaminhados para turmas específicas para trabalharem conceitos essenciais de matemática e português para alfabetização. Depois de trabalharem esses conceitos, retornam as suas turmas regulares ou são encaminhados ao projeto "Acelera", caso estejam com uma defasagem idade-série acima de dois anos. O "Acelera" visa a finalização do ensino fundamental em um tempo menor, para corrigir a distorção. Nesse projeto os alunos ficam em turmas específicas e com um único professor. Diversas cidades e estados brasileiros têm aplicado esse projeto, a partir das mesmas parcerias. As discussões sobre benefícios e/ou malefícios desses projetos, como colocados por Guimarães (2013), estão além do escopo desse estudo. Aqui apenas descrevemos como parte dos projetos pedagógicos que ocorrem nas escolas estudadas.

22 O índice de desenvolvimento da Escola Básica (IDEB) foi elaborado em 2007 pelo INEP para medir resultados da educação no Brasil. Desde então é calculado para cada escola, município e estado considerando as variáveis aprovação (dado anual do censo escolar) e desempenho na Prova Brasil (ou Anresc) (INEP, 2017 b). Mais uma vez, defendemos que resultados de avaliações em larga escala devem ser considerados com cautela, não como uma fidedigna medida dos processos de ensino-aprendizagem. Nesse sentido, uso o valor do IDEB é exposto apenas como mais uma característica descritiva das escolas estudadas.

${ }^{23}$ Esclarecemos que cada tempo de aula era constituído por 50 minutos. 
projeto de extensão de revitalização do "Projeto Fundão Biologia - UFRJ" e foi instrutora de um curso de ensino de Ecologia para professores. Nessa mesma época, trabalhou como mediadora do Museu da Vida da Fundação Osvaldo Cruz (Fiocruz). Depois da graduação, cursou o mestrado no Programa de Pós-graduação em Educação da UFRJ, no qual pesquisou conhecimentos escolares com a temática ambiental em livros didáticos de Ciências do sexto ano do ensino fundamental, com conclusão em 2013. No ano de 2016, enquanto realizávamos o estudo de campo, Valéria participava do grupo de pesquisa "Núcleo de Estudos em Currículo" da Faculdade de Educação da UFRJ e falava sobre as discussões de pesquisa que ali realizava. Ela estava estudando e se preparando para seleção para o doutorado no mesmo Programa. Tendo sido muito bem aprovada, iniciou o doutoramento em 2017.

Em relação à sua história como docente, Valéria trabalhou como professora substituta no Setor Curricular de Ciências Biológicas do CAp/UFRJ em 2009 e 2010 e foi professora temporária da Escola SESC de Ensino Médio em 2015. É professora da rede municipal do Rio de Janeiro desde 2012. O concurso que prestou era para professora de Ciências com 16 horas de trabalho semanal, porém, entre 2013 e 2015 trabalhou com carga horária dupla em uma escola que fazia parte do programa "Ginásio Carioca" 24 . Nessa escola participou de um projeto de extensão em parceria com o "Projeto Fundão Biologia - UFRJ", no qual um laboratório de Ciências para a escola foi montado e diferentes práticas pedagógicas para o ensino de Ciências foram elaboradas. Em 2016, para poder se dedicar aos estudos na universidade e se preparar para o doutorado, pediu transferência para a Escola 2, visando voltar à carga horária de trabalho de 16 horas semanais. Assim, percebemos que a professora Valéria investia fortemente na sua formação e ocupava grande parte de seu tempo com estudos acadêmicos. Possuía uma trajetória de muita dedicação aos estudos e uma forte relação com a universidade desde que se formou. Em sua entrevista e nas conversas nos momentos de convívio, durante o campo, notamos que a professora tinha vários questionamentos ao modelo de gestão da rede municipal do Rio de Janeiro, relatando especialmente a falta de autonomia de

\footnotetext{
${ }^{24}$ O programa Ginásio Carioca foi criado pela Secretaria Municipal de Educação do Rio de Janeiro em 2011 e até o final de 2016 atendia 61 escolas. Essas escolas se diferenciam das demais escolas da rede pela ampliação da jornada escolar, aumento do horário de dedicação dos professores, matriz curricular integrada e técnicas de gestão diferenciadas. O objetivo, de acordo com a Secretaria, é criar escolas piloto para testar novos processos de ensino-aprendizagem.
} 
trabalho, a falta de recursos pedagógicos e nenhum investimento na formação do professor.

A turma 2 da professora Valéria era uma turma de sexto ano do ensino fundamental do turno da tarde. Tinham três tempos de aulas de Ciências por semana, que no início do ano letivo aconteciam às segundas e às terças-feiras e, a partir do segundo semestre, às terças e quintas-feiras. Como o horário da escola mudou no segundo semestre (depois que eu havia acordado as observações com a professora), só pudemos observar semanalmente os dois tempos de aula que aconteciam às terças-feiras, pois às quintas-feiras estávamos na Escola 1. A turma possuía 32 alunos, sendo 13 meninas e 19 meninos, um deles aluno de inclusão. Havia 10 alunos repetentes ( $31 \%$ dos alunos), mas apenas de uma série do ensino fundamental. A turma em geral era frequente, com apenas duas repetências por evasão escolar em 2016. A professora considerava o desempenho acadêmico em Ciências dos alunos baixo, a maioria com conceito regular ou insuficiente. A maior parte dos alunos eram anteriormente da própria escola, mas havia alguns (5 alunos) que vieram transferidos de outras escolas. A professora relatou que no início do ano letivo era uma turma muito agitada e dispersa e por isso resolveu trabalhar com a organização das carteiras escolares de forma individual, uma separada da outra. No segundo semestre, quando acompanhamos a turma, era uma turma participativa e na maior parte do tempo calma e atenta, mas em alguns momentos ficavam bastante agitados, especialmente na hora de fazer os exercícios escritos. Percebemos alguns alunos com muita dificuldade para participar e realizar as atividades propostas.

A Escola 2 fica em uma das ruas principais do bairro de Bonsucesso, na Zona da Leopoldina, região da zona norte da cidade do Rio de Janeiro ( $\left.4^{\mathrm{a}} \mathrm{CRE}\right)$. A história do bairro é marcada por um engenho que funcionava no local na época colonial e depois por uma ampla industrialização, até a década de 1980. Posteriormente, o eixo industrial foi deslocado para outras regiões da cidade e Bonsucesso hoje se caracteriza por uma ampla rede de comércio e serviços, com alguns galpões industriais abandonados. Destacam-se no bairro duas universidades privadas, várias escolas privadas e públicas, o maior hospital federal do Estado do RJ (Hospital Geral de Bonsucesso) e a estação ferroviária. A população estimada em 18.711 habitantes em 2010, é predominantemente de classe média e classe média baixa, com o IDS de 0,615 (58 em IDS entre 158 bairros da cidade do Rio de Janeiro) (CAVALLIERI e LOPES, 2008). Faz fronteira com a Avenida Brasil e 
fica próximo a dois enormes conjuntos de comunidades de baixa renda do Rio de Janeiro, o Complexo da Maré e o Complexo do Alemão.

Para conhecer mais sobre a Escola 2, analisamos documentos fornecidos pela direção, que foram elaborados por professoras da própria escola na ocasião de um aniversário da instituição. Tais documentos descrevem brevemente sua origem e algumas mudanças ao longo do tempo. A escola foi criada em 1949 como uma creche-escola federal para atender à classe trabalhadora vinculada ao Instituto de Aposentadoria e Pensões dos Empregados em Transportes e Cargas (IAPETC). A partir de 1955, o público atendido foi ampliado e a escola se abriu à comunidade. Para isso, houve um investimento também em infraestrutura. Mais tarde, em 1967, a escola passou a ser administrada pelo estado do Rio de Janeiro e deixou de ser creche. Nessa época, de acordo com professoras mais antigas da escola, havia uma grande disputa para efetivação de matrículas, pois a escola era muito procurada pelas famílias da região. Na década de 1970, a escola se tornou municipal e ganhou o nome que possui até hoje, aumentando também o número de matrículas. Em 2016, a escola possuía em torno de 1.500 alunos, atendidos do $2^{\circ}$ ao $9^{\circ}$ ano do ensino fundamental e no projeto especial de regularização de fluxo "Acelera". Funcionava nos turnos da manhã e da tarde, com turmas diferentes e com currículo disciplinar. Como projetos extracurriculares, a escola possuía o projeto de prática esportiva no contra turno "Vôlei em Rede"25 e o programa "Entre Jovens"26. Os alunos que integravam a escola moravam principalmente nas comunidades de baixa renda próximas à escola, alguns em ruas do entorno em Bonsucesso e outros em habitações que beiram a Avenida Brasil.

Segundo a direção da escola, o quadro de professores estava completo em 2016. A maioria dos docentes trabalhava 16 horas na escola, mas alguns poucos atuavam em regime de 40 horas e outros, 22,5 horas (do primeiro segmento do ensino fundamental). Em relação às avaliações em larga escala, o IDEB da escola

\footnotetext{
${ }^{25}$ O projeto "Vôlei em Rede" foi criado em 2010 em uma parceria entre a Secretaria Municipal de Educação e o Instituto Compartilhar, organização privada. Realiza aulas de vôlei no contraturno em diversas escolas municipais e promove um campeonato entre equipes das escolas participantes. Professores de educação física da própria rede são contratados para trabalharem no projeto.

${ }^{26}$ O programa "Entre Jovens" foi criado em 2009 e atende alunos do $9^{\circ}$ ano do ensino fundamental. São realizadas atividades pedagógicas de português e matemática no contraturno, com apoio de licenciandos dessas áreas, e rodas de conversas com estudantes da pedagogia. O objetivo é preparar melhor os alunos do ensino fundamental para cursarem o ensino médio. O projeto foi também criado a partir de uma parceria com um instituto privado.
} 
nos anos finais do ensino fundamental oscilou muito desde 2007. Estava bem acima da meta estipulada pelo MEC em 2007 (4,5 e a meta era de 3,6), teve uma grande queda em 2009 (3,5), cresceu novamente em $2011(4,9)$ e desde então tem diminuído. Em 2015 foi de 3,6 (abaixo da meta estipulada que era de 4,8).

A Escola 2 é formada por duas casas de dois andares, interligadas por um pátio interno amplo. Na frente de uma das casas, na entrada da escola, havia um pátio pequeno com brinquedos, que foi montado para educação infantil e, com a extinção desse nível de escolaridade na instituição, era utilizado pelas crianças menores do primeiro segmento do ensino fundamental. Havia duas quadras na escola, uma coberta e uma aberta. Possuía um laboratório de informática e um espaço para sala de leitura, ambos fechados e desativados em 2016. Tinha ainda uma grande sala de professores, com condicionador de ar, ventiladores, geladeira e micro-ondas. A escola possuía 26 salas de aula com ventiladores (alguns quebrados) e quadro branco. Além disso, havia um refeitório amplo com cozinha, onde se servia o almoço para as crianças. Havia três projetores em funcionamento em 2016, mas de acordo com a professora Valéria, de difícil acesso para uso nas aulas. Na Escola 2, realizamos observações das aulas de Ciências durante 10 dias ao longo do segundo semestre, totalizando 19 tempos de aula.

Foram ainda realizadas observações de aulas de Ciências da professora Catarina. Essa professora se formou em licenciatura em Ciências Biológicas na UFRJ em 2013. Logo após se formar, ingressou no mestrado em agosto de 2014, no Programa de Pós-graduação em Ensino de Ciências, Ambiente e Sociedade da Faculdade de Formação de Professores (FFP) da UERJ, concluído em agosto de 2016. Em sua pesquisa de mestrado, realizou uma análise do tema corpo humano em livros didáticos de Ciências do oitavo ano (ou antiga sétima série), desde a década de 1970 até os anos 2000, com enfoque sócio-histórico do currículo. Durante a graduação, fez iniciação científica durante 2 anos em um laboratório do departamento de Bioquímica Médica da UFRJ. Além disso, participou durante um ano do "Projeto Fundão Biologia - UFRJ" e recebeu durante dois anos bolsas de monitoria da disciplina Biologia Geral do curso de Ciências Biológicas da UFRJ. Em sua entrevista, Catarina declarou ter muita vontade de continuar seus estudos, fazendo doutorado na área de educação. Porém, disse que a Secretaria Municipal de Educação não apoiava essa iniciativa e por isso, não tinha conseguido realizar esse projeto até 2016. Para finalizar o mestrado, por exemplo, a professora não 
conseguiu licença para estudos e teve que trabalhar e fazer sua pesquisa concomitantemente.

Durante o final da graduação e logo depois de se formar, entre o fim de 2013 e agosto de 2014, Catarina trabalhou na educação básica, como monitora de um curso pré-vestibular privado. Quando foi aprovada para o mestrado (com bolsa de estudos), deixou esse trabalho. Em 2015, exerceu o cargo de docente contratada no Colégio Pedro II, campus Realengo. Em conversas durante o convívio para investigação, a professora declarou ter gostado muito de trabalhar nessa escola, principalmente pelo investimento na formação e no trabalho docente. No final de 2015, foi chamada para assumir o cargo de professora de Ciências, após aprovação em um concurso para 40 horas de trabalho semanal na rede escolar municipal do Rio de Janeiro. Durante dois meses em 2015 exerceu o cargo em uma escola municipal na Ilha do Governador, paralelamente à finalização de seu trabalho no Colégio Pedro II e os estudos do mestrado. No início de 2016, se exonerou de seu contrato no Colégio Pedro II (por impossibilidade de conciliar os horários), pediu transferência e começou a trabalhar na Escola 3, na qual a pesquisa foi realizada. Essa escola também fica na Ilha do Governador, bem próxima à residência da professora Catarina na época. A professora cumpria suas 40 horas de trabalho semanal na escola, sendo 32 horas de aula e o restante de avaliação e planejamento. Em 2016, 30 horas de aula semanal da professora eram divididas entre turmas do sexto ao oitavo ano do ensino fundamental, somadas a mais um tempo de aula no contraturno para o quarto ano do ensino fundamental - como aula extra de apoio para ensino-aprendizagem - e mais um tempo no projeto "Acelera". Ela me declarou que pretendia nos próximos anos continuar nessa escola, a não ser que fosse chamada para assumir o cargo em um concurso, no qual foi aprovada, no Colégio Pedro II. Na turma que fizemos nossas observações na Escola 3, Catarina recebia dois licenciandos do curso noturno de licenciatura em Ciências Biológicas da UFRJ, para realização do estágio de formação inicial docente. Traçando um perfil geral da professora na época de realização do campo, parece-nos que Catarina era uma professora recém-formada, com pouca experiência na escola, mas enorme comprometimento com o trabalho e dedicação aos estudos. Sua relação com a academia e comprometimento com o trabalho era perceptível na realização do mestrado (mesmo concomitantemente ao trabalho de 40 horas na escola), no trabalho como orientadora de estágio inicial docente e na proposta de oficinas e 
trabalhos extras que realizava na escola. No primeiro semestre de 2016, por exemplo, Catarina ajudou a direção a montar um laboratório escolar de Ciências e contribuiu na organização de uma oficina de formação continuada para aulas de Ciências com experimentação para as professoras do primeiro segmento do ensino fundamental, em parceira com o "Projeto Fundão Biologia - UFRJ".

A turma que observamos da professora Catarina foi a turma 3, que tinha 37 estudantes, 15 meninos e 22 meninas. Essa turma frequentava o turno da manhã, com três tempos de aula semanais de Ciências as sextas-feiras, dois tempos seguidos e mais um após o recreio. Dentre os alunos, havia apenas 3 repetentes de um único ano do primeiro segmento do ensino fundamental (3,8\% dos alunos). A grande maioria dos estudantes da turma frequentavam a Escola 3 desde o primeiro ano do ensino fundamental. A professora considerava o desempenho dessa turma bom, comparado às demais turmas de sexto ano da escola e atribuía isso ao fato de naquele período essa ser a única turma de sexto ano na qual quase a totalidade dos alunos eram provenientes da própria escola. A maioria dos estudantes tinha desempenho bom ou regular no conceito geral e nas aulas de Ciências, apenas seis tinham conceito global insuficiente. Além disso, era uma turma muito frequente. Todos os alunos da turma moravam na Ilha do Governador, a maioria no próprio conjunto habitacional do qual a escola fazia parte.

A Escola 3 fica na Praia da Bandeira, na Ilha do Governador, uma grande ilha com área de $36,12 \mathrm{Km}^{2}$ localizada na zona norte do Rio de Janeiro e com realidades socioeconômicas muito heterogêneas, com dezenas de comunidades de baixa renda e bairros com populações de alto poder aquisitivo em convívio. A Praia da Bandeira é um bairro urbano de classe média com população estimada em 5.948 habitantes (em 2010) e IDS de 0,650 (em uma escala até 1, o $40^{\circ}$ valor entre os 158 bairros da cidade do Rio de Janeiro) (CAVALLIERI e LOPES, 2008). O bairro ocupa desde uma faixa arenosa na beira da baía de Guanabara até o morro da Tapera atrás dela. No final dos anos de 1940 até 1960, possuía uma Indústria de água mineral e uma Estação de Águas, única no então Distrito Federal, mas atualmente é basicamente um bairro residencial, com vários Conjuntos Habitacionais que ocupam o morro da Tapera. A Escola 3 se localiza em um desses conjuntos.

A escola foi fundada em 1990, já como uma escola pertencente à Secretaria Municipal de Educação do Rio de Janeiro. O terreno para construção foi doado pela associação de moradores do Conjunto Habitacional e a escola foi construída pela 
então prefeitura da cidade, visando atender a comunidade que ali vivia. Em sua origem, atendia da educação infantil ao final do ensino fundamental, mas ao longo do tempo (a partir de 1996 segundo funcionários mais antigos da escola) foi se tornando uma escola exclusivamente de ensino fundamental, atendendo em 2016 aproximadamente 675 estudantes do $1^{\circ}$ ao $9^{\circ}$ ano desse nível de escolaridade. Funcionava nos turnos da manhã e da tarde. O primeiro segmento do ensino fundamental funcionava com séries distintas de manhã $\left(1^{\circ}, 2^{\circ}\right.$ e $3^{\circ}$ anos) e a tarde $\left(4^{\circ}\right.$ e $5^{\circ}$ anos), e o segundo segmento funcionava nos dois turnos com turmas de todos os anos ( $6^{\circ}$ ao $9^{\circ}$ ano). Assim, em cada série do segundo segmento havia uma turma cujos estudantes vinham praticamente todos da própria escola, e mais duas ou três que eram formadas por estudantes que chegavam no sexto ano. Além das aulas regulares, com currículo disciplinar, no colégio aconteciam os projetos "Edupark"27, “Acelera”, "Entre Jovens” e "Mais Educação"28, que incluía em 2016 oficinas de grafite, oficinas de teatro, desenvolvimento de um jornal pelos estudantes e oficinas de dança.

$\mathrm{O}$ prédio tem uma arquitetura premiada diferenciada, com andares intercalados, paredes com aberturas para circulação de ar e entrada de luz e uma área mais ampla no térreo, onde ficava o refeitório com uma pequena horta vertical. Ele fica no alto do morro da Tapera, em um terreno bastante íngreme, em uma área considerada de difícil acesso por falta de transporte público, de forma que os professores e funcionários recebiam em 2016 um adicional salarial por isso. Tratase de um prédio sem muita área externa - em 2016 havia apenas uma quadra, uma pequena parte na entrada da escola e um estacionamento embaixo do prédio. A infraestrutura contava, em 2016, com a quadra aberta, que só era ocupada nas aulas de Educação Física, um laboratório de informática com pouco computadores (5

\footnotetext{
${ }^{27}$ O projeto "Edupark" é mais um exemplo de parceria público-privada da Secretaria de Educação do município do Rio de Janeiro. Esse projeto é fruto de uma parceria entre o Instituto Antares, Fundação Cesgranrio e a Secretaria de Educação. Nele, são feitas apresentações nas escolas de filmes em três dimensões, associados à tecnologia multissensorial e aliados à uma proposta interativa computacional, abrangendo diferentes pacotes temáticos (científico, cultural, social e cidadania). É um projeto recente, adaptado de um projeto desenvolvido em Israel. Foi iniciado em 2015 para atender alunos do segundo segmento do ensino fundamental.

${ }^{28}$ O "Mais Educação" é um programa realizado pela Secretaria de Educação Básica do Ministério da Educação do Brasil (MEC), em parceria com secretarias estaduais e municipais de educação. Tem como objetivo principal ampliar a carga horária das crianças na escola para no mínimo 7 horas diárias, oferecendo apoio pedagógico e atividades culturais e de lazer nas escolas. Para isso, o programa se baseia principalmente no repasse direto para as escolas de recursos do governo federal para ressarcimento de monitores, aquisição de materiais e contratação de pequenos serviços. $\mathrm{Na}$ Secretaria de Educação municipal do Rio de Janeiro, o "Mais Educação" ocorre desde 2009.
} 
computadores), um laboratório de ciências bem equipado (com modelos, vidraria e bancadas), sala de leitura, auditório, sala de vídeo bem equipada com televisão grande, tela, DVD, som e projetor, 10 salas de aula com quadro branco, projetor e condicionador de ar, uma sala de professores com geladeira, micro-ondas, cafeteira e condicionador de ar, e o refeitório com cozinha e uma horta vertical de temperos.

Estudantes que frequentavam a escola, em sua maioria, vinham do próprio Conjunto Habitacional onde ela fica, mas alguns vinham de comunidades de baixa renda próximas ou de bairros do entorno. A maior parte dos funcionários da escola também vivia no Conjunto Habitacional, assim como alguns professores. Nesse sentido, parecia-nos uma escola com uma comunidade escolar bem demarcada. Um funcionário antigo da escola, reportou-nos em entrevista que estudavam na escola muitos filhos de ex-estudantes e que conheciam as famílias e histórias das crianças, pois todos vivam próximos.

$\mathrm{Na}$ escola, havia professores mais antigos com contrato de trabalho de 16 horas semanais (maioria) e outros provenientes de concursos mais recentes, com 40 horas semanais de trabalho, como a professora Catarina. O quadro docente estava completo em 2016, embora alguns dobrassem a matrícula na escola. Nas avaliações externas, o IDEB dos anos finais do ensino fundamental caiu muito de 2007 a 2011, subiu em 2013 e caiu novamente em 2015, ficando abaixo da meta nesse último ano (média 4,0 em comparação à meta de 4,7).

Na Escola 3 observamos 20 tempos de aula, divididos em 7 dias que estivemos na escola. Como as aulas só aconteciam às sextas-feiras e muitos eventos da escola e feriados ocorreram nesse dia, houve poucos dias de aulas para observação. Entretanto, como a cada dia aconteciam três tempos de aula, o número de tempos foi semelhante aos observados nas escolas 1 e 2 .

Visando construir uma síntese do que descrevemos, organizamos os dados dos perfis das professoras (QUADRO 1), das turmas (QUADRO 2) e das escolas que participaram da investigação (QUADRO 3) nos quadros a seguir: 
QUADRO 1 - Perfis das professoras de Ciências que participaram da investigação

\begin{tabular}{|c|c|c|c|}
\hline & Professora Carla & $\begin{array}{c}\text { Professora } \\
\text { Valéria }\end{array}$ & $\begin{array}{c}\text { Professora } \\
\text { Catarina }\end{array}$ \\
\hline Formação & $\begin{array}{l}\text { - Licenciatura e } \\
\text { bacharelado: } 2005 ; \\
\text { - Mestrado: } 2007 .\end{array}$ & $\begin{array}{l}\text { - Licenciatura e } \\
\text { bacharelado: 2009; } \\
\text { - Mestrado: 2013; } \\
\text { - Doutoranda. }\end{array}$ & $\begin{array}{l}\text { - Licenciatura: 2013; } \\
\text { - Mestrado: } 2016 .\end{array}$ \\
\hline $\begin{array}{l}\text { Experiência } \\
\text { profissional }\end{array}$ & $\begin{array}{l}\text { - Cursos pré- } \\
\text { vestibulares desde a } \\
\text { graduação; } \\
\text { - } \quad \text { Escolas } \\
\text { particulares; } \\
\text { - Escolas Públicas. }\end{array}$ & $\begin{array}{l}\text { - Museu da vida; } \\
\text { - Escola particular; } \\
\text { - Substituta em } \\
\text { escola federal. }\end{array}$ & $\begin{array}{l}\text { - Substituta em } \\
\text { escola federal; } \\
\text { - Monitoria em } \\
\text { escola particular. }\end{array}$ \\
\hline Atuação & $\begin{array}{l}\text { - Município do Rio } \\
\text { de Janeiro (16 } \\
\text { horas); } \\
\text { - Município de } \\
\text { Niterói (16 horas). } \\
\text { - Escola privada em } \\
\text { Niterói (12 horas) }\end{array}$ & \begin{tabular}{ll}
\multicolumn{3}{l}{ - Município do Rio } \\
de Janeiro \\
horas); \\
- Grupo \\
pesquisa.
\end{tabular} & $\begin{array}{l}\text { - Município do Rio } \\
\text { de Janeiro } \\
\text { horas). }\end{array}$ \\
\hline
\end{tabular}

QUADRO 2 - Perfis das turmas de $6^{\circ}$ ano do ensino fundamental que participaram da investigação

\begin{tabular}{|c|c|c|c|}
\hline & $\begin{array}{c}\text { Turma } 1602 \\
\text { (Escola 1) }\end{array}$ & $\begin{array}{c}\text { Turma } 1608 \\
\text { (Escola 2) }\end{array}$ & $\begin{array}{c}\text { Turma 1601 } \\
\text { (Escola 3) }\end{array}$ \\
\hline Formação & $\begin{array}{l}\text { - } 18 \text { meninas e } 16 \\
\text { meninos; } \\
\text { - Alunos vieram da } \\
\text { própria escola. }\end{array}$ & $\begin{array}{l}\text { - } 13 \text { meninas e } 19 \\
\text { meninos; } \\
\text { - A maioria veio da } \\
\text { própria escola e } 5 \\
\text { são transferidos de } \\
\text { outras escolas. }\end{array}$ & $\begin{array}{l}\text { - } 22 \text { meninas e } 15 \\
\text { meninos; } \\
\text { - Alunos vieram da } \\
\text { própria escola. }\end{array}$ \\
\hline $\begin{array}{l}\text { Desempenho } \\
\text { escolar } \\
\text { (de acordo } \\
\text { com as } \\
\text { professoras) }\end{array}$ & $\begin{array}{l}\text { - } 5 \text { repetentes; } \\
\text { - Frequência alta; } \\
\text { - Desempenho } \\
\text { acadêmico } \\
\text { mediano. }\end{array}$ & $\begin{array}{l}\text { - } 10 \text { repetentes; } \\
\text { - } \quad \text { Frequência } \\
\text { mediana; } \\
\text { - Desempenho } \\
\text { acadêmico baixo. }\end{array}$ & $\begin{array}{l}\text { - } 3 \text { repetentes; } \\
\text { - Frequência alta; } \\
\text { - } \quad \text { Desempenho } \\
\text { acadêmico bom. }\end{array}$ \\
\hline Moradia & $\begin{array}{l}\text { - Comunidades do } \\
\text { entorno da escola } \\
\text { (Catumbi) }\end{array}$ & $\begin{array}{l}\text { - Comunidades da } \\
\text { Maré e Alemão. } \\
\text { - Avenida Brasil }\end{array}$ & $\begin{array}{l}\text { - Conjunto } \\
\text { Habitacional onde a } \\
\text { escola se localiza. }\end{array}$ \\
\hline
\end{tabular}


QUADRO 3 - Perfis das escolas que participaram da investigação

\begin{tabular}{|c|c|c|c|}
\hline & Escola 1 & Escola 2 & Escola 3 \\
\hline Localização & $\begin{array}{l}\text { - Catumbi; } \\
\text { - Zona conflagrada. }\end{array}$ & Bonsucesso & $\begin{array}{l}\text { Praia da Bandeira } \\
\text { (Ilha } \\
\text { Governador) }\end{array}$ \\
\hline Histórico & $\begin{array}{l}\text { - } 1929 \text { (escola } \\
\text { anisiana). }\end{array}$ & $\begin{array}{lr}\text { - } 1949 \text { (fundada } \\
\text { como } & \text { creche- } \\
\text { escola } & \text { do } \\
\text { IAPETC). } & \end{array}$ & $\begin{array}{lr}\text { - } 1990 \text { (construída } \\
\text { como } & \text { escola } \\
\text { municipal } & \text { pela } \\
\text { prefeitura } & \text { em } \\
\text { terreno doado } & \text { pela } \\
\text { associação } & \text { de } \\
\text { moradores). } & \end{array}$ \\
\hline $\begin{array}{c}\text { Número de } \\
\text { alunos e séries } \\
\text { atendidas }\end{array}$ & 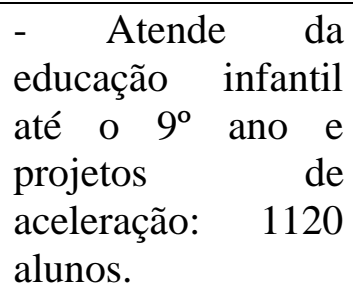 & $\begin{array}{lr}\text { - Atende } & \text { da } \\
\text { educação infantil } \\
\text { até o } 9^{\circ} \text { ano e } \\
\text { projetos } & \text { de } \\
\text { aceleração: } & 1120 \\
\text { alunos }\end{array}$ & $\begin{array}{l}\text { - Atende do } 1^{\circ} \text { até o } \\
9^{\circ} \text { ano e projetos de } \\
\text { aceleração: } \quad 675 \\
\text { alunos }\end{array}$ \\
\hline Infraestrutura & \begin{tabular}{l}
\multicolumn{1}{c}{ Muito boa } \\
infraestrutura (salas \\
de aula com \\
condicionadores de \\
ar e projetores; \\
teatro; sala de \\
leitura; laboratório \\
de informática \\
equipado; \\
laboratório de \\
Ciências; sala de \\
vídeo; quadra \\
aberta e quadra \\
coberta, entre \\
outros).
\end{tabular} & $\begin{array}{l}\text { - Falta de } \\
\text { materiais } \\
\text { (laboratório de } \\
\text { Ciências, } \\
\text { laboratório de } \\
\text { informática e sala } \\
\text { de leitura } \\
\text { fechadas; salas de } \\
\text { aula apenas com } \\
\text { ventiladores; } \\
\text { poucos projetores } \\
\text { para toda escola). }\end{array}$ & $\begin{array}{l}\text { - Boa infraestrutura } \\
\text { (laboratório de } \\
\text { Ciências, salas de } \\
\text { aula rom } \\
\text { condicionadores de } \\
\text { ar; sala de vídeo; } \\
\text { laboratório de } \\
\text { informática com } \\
\text { poucos } \\
\text { computadores; } \\
\text { alguns projetores } \\
\text { quebrados; sala de } \\
\text { leitura; pouca área } \\
\text { externa). }\end{array}$ \\
\hline
\end{tabular}

\subsection{2.}

\section{Método de observação e análise dos dados}

Observamos as aulas de Ciências de três turmas de sexto ano do ensino fundamental de três diferentes escolas municipais onde as professoras selecionadas para a investigação trabalhavam. Apresentamos a seguir uma tabela com o número total de tempos de aula observados (TABELA 1). Não diferenciamos na tabela os dias que comparecemos em cada escola, considerando as observações como um conjunto. A partir desse momento do texto da tese, consideraremos as práticas 
observadas e analisadas como um todo, visto que nosso objetivo não é fazer uma análise comparativa, mas sim estudar um conjunto de práticas pedagógicas em aulas de Ciências. Os perfis construídos (das professoras, das escolas e das turmas) ajudaram-nos a perceber a diversidade das realidades pesquisadas, mas não foram desenvolvidos visando a comparação.

TABELA 1 - Datas e tempo de observações de aulas de Ciências das três professoras que participaram da investigação

\begin{tabular}{|c|c|}
\hline Data de Observação & Tempos de aula observados \\
\hline $08 / 09 / 2016$ & 2 \\
\hline 09/09/2016 & $3+1$ (em escolas diferentes) \\
\hline $13 / 09 / 2016$ & 2 \\
\hline $15 / 09 / 2016$ & 2 \\
\hline 20/09/2016 & 2 \\
\hline $22 / 09 / 2016$ & $2+1$ (em escolas diferentes) \\
\hline 23/09/2016 & $3+1$ (em escolas diferentes) \\
\hline $27 / 09 / 2016$ & 2 \\
\hline $29 / 09 / 2016$ & 2 \\
\hline 06/10/2016 & 2 \\
\hline $13 / 10 / 2016$ & 2 \\
\hline $18 / 10 / 2016$ & 2 \\
\hline $20 / 10 / 2016$ & 2 \\
\hline $21 / 10 / 2016$ & 3 \\
\hline $01 / 11 / 2016$ & 2 \\
\hline $03 / 11 / 2016$ & 2 \\
\hline $04 / 11 / 2016$ & 3 \\
\hline $08 / 11 / 2016$ & 2 \\
\hline $10 / 11 / 2016$ & 2 \\
\hline $18 / 11 / 2016$ & 3 \\
\hline $22 / 11 / 2016$ & 2 \\
\hline $25 / 11 / 2016$ & 3 \\
\hline $29 / 11 / 2016$ & 2 \\
\hline $09 / 12 / 2016$ & 2 \\
\hline $13 / 12 / 2016$ & 2 \\
\hline
\end{tabular}


As observações como método de pesquisa foram realizadas como descrições detalhadas dos acontecimentos nas aulas de Ciências, com anotações em cadernos de campo, que foram complementadas por audiogravações dos diálogos ocorridos ${ }^{29}$. Antes de realizar as observações nas escolas descritas, fizemos um trabalho de exploração em um estudo piloto, usado para testar o método e perceber dificuldades que poderiam aparecer. $\mathrm{O}$ estudo piloto foi realizado com observações de aulas de Ciências de uma professora de uma turma do sétimo ano de uma escola municipal na Gávea, Zona Sul do Rio de Janeiro. Compareci a essa escola sete dias, entre abril e junho de 2016, observando nesse estudo piloto 12 tempos de aula.

Esse estudo foi importante para percebermos a complexidade de realizar observações como método científico. A princípio, trabalhamos apenas com anotações em caderno de campo, a partir de um roteiro estruturado. A primeira dificuldade vivenciada foi a perda de informações, que julgamos importantes para as observações, devido ao roteiro estruturado. No momento da análise dos dados, apareciam dúvidas sobre fatos ocorridos nas aulas que não tinham sido detalhados no roteiro, de forma que escolhemos mudar a maneira de anotar as observações e coletar o máximo de dados possível, sem a limitação de um roteiro fechado. Assim, optamos por realizar anotações mais livres do que estávamos observando, para assim conseguir produzir mais dados para reflexão. Porém, isso trouxe dificuldades para manter o foco durante as observações. Desenvolvemos então um método semiestruturado de observação, no qual o ocorrido nas aulas era anotado sequencialmente, como uma narrativa, mas focando nos momentos de leitura e escrita de textos (e interações em torno desses textos). No estudo piloto, percebemos também que era muito difícil anotar diálogos importantes que ocorriam em interações nas atividades pedagógicas. Os eventos aconteciam muito rapidamente e perdíamos algumas falas importantes. A partir dessa percepção, decidimos gravar o áudio das aulas.

O estudo piloto também colaborou para escolha de realizar uma observação não participante, na qual o pesquisador não participa diretamente do fenômeno que está sendo observado, buscando não interceder nos eventos ocorridos. $\mathrm{Na}$ investigação realizada não interferimos nas atividades pedagógicas desenvolvidas.

\footnotetext{
${ }^{29}$ Por problemas técnicos com o gravador, 10 tempos de aula (do total geral de 59 tempos) não foram audiogravados, mas esses dados foram cuidadosamente elaborados no caderno de campo.
} 
Essa escolha se justifica porque desejávamos pesquisar situações que realmente ocorriam em aulas de Ciências, e não situações produzidas pela pesquisadora. Assumimos que a presença da pesquisadora pode ter causado mudanças comportamentais que interferiram nas interações observadas, especialmente nos primeiros dias de observações, mas o próprio estudo piloto mostrou que ao longo do tempo essa presença se tornava naturalizada e as professoras e estudantes passavam a agir normalmente. Apesar de termos optado por uma observação não participante, achamos apropriado explicitar para as turmas meu papel de observadora, por uma questão ética, explicando os objetivos da pesquisa e o que eu estaria fazendo no espaço da sala de aula. Nas três escolas, as professoras me apresentaram e me ajudaram a conversar com os alunos sobre a pesquisa.

As anotações do caderno de campo e as gravações obtidas nas observações foram transcritas, mesclando as anotações com os diálogos gravados das atividades de leitura e/ou escrita que ocorreram nas aulas de Ciências. Transcrevemos todo o caderno de campo e para transcrição dos áudios, recebemos a colaboração de outras pesquisadoras do grupo de pesquisa. Após a transcrição, analisamos os dados com auxílio do software ATLAS.ti.

O ATLAS.ti é um programa de computador de apoio à análise de dados qualitativos (computer assisted qualitative data analysis software -CAQDAS) que tem sido utilizado na pesquisa em Educação no Brasil de diferentes formas (LAGE, 2011). Na presente investigação, o programa foi utilizado na organização dos dados das observações. Para isso, inicialmente inserimos os documentos de cada dia das observações no programa. Cada documento era composto pela transcrição de uma aula, incluindo as anotações do caderno de campo intercaladas pela transcrição da audiogravação. Após a inserção no programa, os documentos foram analisados, dividindo-os em partes (de acordo com a unidade de análise estabelecida). Depois, em cada unidade de análise buscamos padrões e criamos categorias analíticas que apareciam ali exemplificadas (códigos de análise). O programa nos ajudou, principalmente, a estudar os dados com atenção, lendo cada documento várias vezes e procurando padrões que se refletiam nas categorias. Através dele, pudemos selecionar as unidades e classificá-las com mais cuidado. Como o volume de dados das observações era muito grande, o programa foi fundamental para organização das análises. Além disso, o programa ajudou na busca de exemplos nas aulas observadas, para a escrita do relato da pesquisa. 
A unidade de análise criada para a interpretação dos dados foram as atividades pedagógicas realizadas nas aulas de Ciências envolvendo leitura e/ou escrita. A partir da concepção de leitura e de escrita com a qual trabalhamos, a unidade de análise incluiu não só o texto lido ou escrito em si, mas todos os diálogos que ocorreram envolta do texto, como parte das interações sociais que estabelecem a leitura e a escrita. Assim, em uma atividade de leitura, é parte da unidade de análise as intervenções que a professora realizou antes da leitura em si, assim como discussões colocadas ao longo e depois do texto pela professora ou pelos estudantes. Em atividades de escrita, o diálogo sobre os objetivos da atividade e sobre o que foi produzido, também fazem parte da unidade de análise.

Na próxima seção, discutimos mais profundamente as categorias utilizadas no estudo destas unidades de análise.

\subsubsection{1. Categorias analíticas}

As unidades de análise, compostas por atividades pedagógicas envolvendo leitura e/ou escrita das aulas de Ciências, foram classificadas utilizando categorias (famílias de dados) divididas em subcategorias. As categorias e subcategorias foram criadas a partir dos referenciais teórico-metodológicos da pesquisa, em diálogo com os próprios dados. Foram desenvolvidas ao longo das análises, na interpretação dos dados. Destacamos que não serviram para quantificar os dados, mas apenas para nos ajudar a olhar para eles com mais profundidade. Nesse sentido, foram utilizadas como apoio para o estudo dos dados e desenvolvimento de uma análise interpretativa. Destacamos no quadro a seguir categorias e subcategorias usadas na análise dos dados das observações das aulas (QUADRO 4).

QUADRO 4 - Categorias e subcategorias usadas na análise dos dados das observações de atividades pedagógicas com leitura e/ou escrita de aulas de Ciências.

\begin{tabular}{|l|l|}
\hline \multicolumn{1}{|c|}{ Categorias (famílias) } & \multicolumn{1}{|c|}{ Subcategorias (códigos) } \\
\hline \multirow{2}{*}{ Tipo de atividade pedagógica } & $\begin{array}{l}\text { Leitura de textos e/ou resposta de exercícios } \\
\text { escritos do Caderno Pedagógico }\end{array}$ \\
\cline { 2 - 2 } & Experimentação \\
\cline { 2 - 2 } & Avaliação formal \\
\cline { 2 - 2 } & Outras (caderno, livro didático, estudo dirigido) \\
\hline
\end{tabular}




\begin{tabular}{|c|c|}
\hline \multirow{3}{*}{$\begin{array}{l}\text { Finalidades ou tradições } \\
\text { curriculares do ensino de Ciências }\end{array}$} & Tradição acadêmica \\
\hline & Tradição utilitária \\
\hline & Tradição pedagógica \\
\hline \multirow{5}{*}{$\begin{array}{l}\text { Enfoques curriculares do ensino de } \\
\text { Ciências }\end{array}$} & História Natural \\
\hline & Ecologia \\
\hline & Fisiologia, anatomia e saúde humanas \\
\hline & Ciência e experimentação \\
\hline & Vida cotidiana \\
\hline \multirow{3}{*}{ Gêneros discursivos } & Primário \\
\hline & Secundário \\
\hline & Híbrido (primário e secundário) \\
\hline \multirow{3}{*}{ Tipos de atividade de leitura } & Leitura individual \\
\hline & Leitura de texto pela professora \\
\hline & Leitura coletiva pela turma \\
\hline \multirow{5}{*}{ Estratégias em atividades de leitura } & Análise do título do texto \\
\hline & Discussão do conteúdo antes da leitura \\
\hline & Levantamento de conhecimentos prévios \\
\hline & Discussão de sentidos de palavras \\
\hline & Discussão ao longo da leitura \\
\hline \multirow{4}{*}{ Tipos de atividade de escrita } & Escrita individual \\
\hline & Escrita no quadro a partir de discussão \\
\hline & Cópia \\
\hline & Ditado \\
\hline \multirow{3}{*}{ Estratégias em atividades de escrita } & Discussão de ortografia \\
\hline & Discussão de conteúdo antes da atividade \\
\hline & Discussão do solicitado em atividades de escrita \\
\hline \multirow{3}{*}{ Autoria } & Texto autoral \\
\hline & Autoria híbrida \\
\hline & Texto não autoral \\
\hline
\end{tabular}

A primeira categoria se refere ao tipo de atividade pedagógica efetivamente observada nas aulas de Ciências que envolveu a linguagem escrita. Essa categoria serviu para classificação inicial das unidades de análise. Diz respeito, principalmente, à reflexão sobre o método pedagógico e materiais didáticos 
utilizados nas aulas que assisti, ou seja, se foram atividades com o Caderno Pedagógico, atividades com experimentação, provas (avaliações formais) ou outras atividades, como cópia de textos e exercícios escritos no caderno dos alunos, estudos dirigidos elaborados pelas professoras, uso do livro didático, etc. O uso dos Cadernos Pedagógicos foi destacado como categoria devido à alta frequência nas observações.

Depois de entender o tipo de atividade que estava sendo realizada, analisamos aspectos mais específicos da disciplina escolar Ciências. Entendendo que a pesquisa relatada se encontra em uma zona de fronteira entre estudos do campo do ensino de Ciências e estudos da linguagem. Por isso, procuramos trazer contribuições de ambos para as categorias de análise.

Para reflexão sobre o ensino de Ciências, estudamos as finalidades ou tradições curriculares da disciplina escolar Ciências que a atividade congregava. Para pensar sobre estas finalidades, nos baseamos em Goodson (1995, 1997 e 2001). Como aprofundamos nos referenciais teórico-metodológicos, Goodson, a partir de estudos sócio-históricos do currículo, discute que as disciplinas escolares são formadas por diferentes tradições curriculares, que são moldadas a partir de intenções e forças sociais diversas. De acordo com o autor, essas forças levam as disciplinas escolares a hegemonizarem determinados conteúdos e métodos em seus currículos, em um padrão semelhante em diversos países do mundo. Para entender esse processo, Goodson se baseia especialmente no modelo de Layton (1973 apud Goodson, 2001) que estuda a evolução das disciplinas escolares e define diferentes tradições curriculares que as formam ao longo de suas trajetórias: a acadêmica, a utilitária e a pedagógica. Seus estudos mostram que, em geral, as disciplinas escolares são introduzidas no currículo vinculadas a finalidades pedagógicas e utilitárias, mas sua consolidação leva à vinculação a uma tradição mais acadêmica. As tradições acadêmicas se associam à formação universitária e à formação profissional a qual o aluno está destinado, envolvendo o interesse em formar os estudantes na maneira de pensar e agir característica de uma dada disciplina acadêmica ou científica. As tradições utilitárias dizem respeito ao conhecimento de baixo status e se relacionam às vocações não profissionais universitárias, nas quais a maioria das pessoas trabalha. Envolvem habilidades básicas utilizadas no trabalho em geral e na solução de problemas práticos da vida cotidiana. As tradições pedagógicas se articulam à ênfase nos processos de como 
as crianças aprendem. Assim, ao categorizarmos as atividades de acordo com essas tradições, analisamos os objetivos da atividade e seu conteúdo. Atividades cujo objetivo principal era o ensino-aprendizagem de conceitos ligados às ciências de referência que integram a disciplina Ciências foram classificadas como acadêmicas. Aquelas que tinham como objetivo discutir aspectos relativos a questões sociais mais básicas, como higiene e comportamentos, eram utilitárias, e por fim as que se referiam a questões específicas de aprendizagem, como métodos ativos de ensino-aprendizagem, leitura de gráficos, etc., foram compreendidas como pedagógicas.

Ainda em relação ao campo de pesquisa do ensino de Ciências, analisamos as atividades de acordo com os enfoques curriculares nas quais se inseriam, com base em Gomes (2008). Em seu trabalho, já comentado, a pesquisadora analisou livros didáticos de Ciências de 1930 a 2000 e mostrou que a tensão modificações/estabilidade desta disciplina escolar deu origem ao que a autora denomina enfoques organizadores do currículo, que determinam a seleção, organização e distribuição de conteúdos e métodos de ensino na disciplina Ciências. Dentre esses, evidenciaram-se nas nossas observações história natural; ecologia; anatomia, fisiologia e saúde humanas; ciência e a experimentação; e vida cotidiana. Esses enfoques organizadores do currículo de Ciências se inserem em uma perspectiva ampla das finalidades educacionais da disciplina e mesclam tradições utilitárias, pedagógicas e acadêmicas, tais como as propostas por Goodson. $\mathrm{O}$ enfoque curricular história natural se relaciona aos estudos iniciais de botânica, zoologia, mineralogia, geologia e paleontologia. Revela perspectivas científicas caracterizadas por descrições detalhadas, coleções e classificações do mundo natural, assim como a visão evolutiva dos seres vivos. De acordo com Gomes (2008), esse enfoque é influenciado tanto por tradições mais acadêmicas da história da disciplina científica Biologia, quanto por tradições mais pedagógicas, relacionadas a descrever o mundo natural para as crianças e adolescentes. A ecologia como enfoque curricular agrega conhecimentos de finalidades mais acadêmicas, provenientes da Ecologia Biológica como campo de pesquisa, e conhecimentos de finalidades mais pedagógicas e utilitárias, que se referem à Educação Ambiental. O enfoque anatomia, fisiologia e saúde humanas aparece no ensino de Ciências como estudo da estrutura e funcionamento do corpo humano - tradição acadêmica - e inclui também a discussão de aspectos da saúde e bem- 
estar, tradições mais pedagógicas e utilitárias. Ciência e experimentação traz a marca da perspectiva positivista de ciência, identificada por um método científico experimental comum a toda produção científica. Tenta-se integrar versões de experimentação e método científico relativas a diversos campos científicos como a Biologia, a Física e a Química. “A experimentação pode ser vista como oriunda de uma tradição acadêmica que se mescla com tradições de natureza pedagógica a partir das versões escolares de experimentação que surgem no contexto escolar" (GOMES, 2008, pg. 54). O enfoque vida cotidiana apresenta-se nos livros como aspectos da vida doméstica e/ou profissional e, nesse sentido, se refere a tradições utilitárias e, às vezes, pedagógicas.

Em relação às contribuições de estudos da linguagem, apoiamo-nos na perspectiva bakhtiniana para refletir sobre os gêneros discursivos que caracterizaram os diálogos e textos escritos das atividades que observamos nas aulas. Bakhtin discute que o emprego da língua ocorre através de enunciados únicos e concretos, proferidos pelos sujeitos que compõem os diversos campos de atividade humana. Os enunciados refletem as condições e finalidades destes campos a partir do seu conteúdo temático, do estilo da linguagem (recursos lexicais e gramaticais da língua) e a construção composicional. Esses três elementos se ligam no conjunto do enunciado e determinam formas relativamente estáveis de enunciados que caracterizam cada campo de utilização da língua e se denominam gêneros discursivos. Como são inúmeros os campos de atividade humana, há uma extrema heterogeneidade de gêneros discursivos. Para o autor, o estudo dos gêneros é fundamental para compreensão dos enunciados concretos que constituem os materiais linguísticos. Dividimos os tipos de gêneros observados em dois grupos principais, os gêneros primários e os gêneros secundários do discurso. Segundo Bakhtin, "a natureza do enunciado deve ser descoberta e definida por meio da análise de ambas as modalidades" (BAKHTIN, 2016, pg. 15). A diferença entre estes gêneros é essencial e ideológica. Os gêneros primários são simples e se formam nas condições discursivas imediatas, em condições espontâneas de comunicação. Os gêneros secundários são mais complexos, pois surgem em condições de um convívio cultural mais complexo e relativamente mais desenvolvido e organizado, são discursos estruturados em uma relação mediata com a realidade, não espontânea, costumam ser associados à escrita. Para o estudo dos gêneros discursivos nas unidades de análise, buscamos considerar os parâmetros 
da situação de produção da enunciação, visto que "os gêneros $e$ os textos/enunciados a eles pertencentes não podem ser compreendidos, produzidos ou conhecidos sem referência aos elementos de sua situação de produção" (ROJO, 2005, pg. 196). Essa situação de produção, em nossa pesquisa, se referiu à realização das atividades em sala de aula. Assim, nas análises buscamos perceber os gêneros predominantes nos enunciados proferidos nos diálogos sobre os textos e na leitura e/ou escrita dos mesmos. Quando se relacionavam a campos complexos, como o científico, eram compreendidos como enunciados pertencentes a um gênero secundário. Se eram falas mais ligadas a questões cotidianas, trazendo discursos mais simples, concretos e/ou imediatos de produção entendemos como um gênero primário. Porém, como nossa unidade de análise foi a atividade inteira, estudamos o conjunto dos enunciados, percebendo se algum gênero predominava ou se se articulavam ao longo da atividade pedagógica, formando o que denominamos de híbrido de gêneros primários e secundários. Reconhecemos que essa classificação se mostrou simplista e difícil em determinados momentos, especialmente por causa da mobilidade e flexibilidade da linguagem, afinal, em uma perspectiva bakhtiniana, há sempre novos gêneros discursivos em construção. Além disso, é possível determinar a passagem dos gêneros primários para os gêneros secundários do discurso na linha filogenética e histórica, mas não tão facilmente no uso cotidiano da linguagem. Na prática, estamos sempre transitando entre diferentes estilos verbais e há sempre algum tipo de hibridização manifesta nos gêneros discursivos. Com uma forte inter-relação, será possível sempre surpreender elementos característicos dos gêneros primários em uso nos gêneros secundários, visto que estes últimos se constroem pela assimilação dos primeiros. Nesse sentido, realizamos essa classificação para entendermos melhor os movimentos de linguagem que ocorriam nos diálogos com os textos, mas não para delimitar exatamente quando estava sendo utilizado um gênero ou outro. Nossa intenção foi compreender se havia predomínio de discursos primários ou secundários em cada situação e em que medida esses se articulavam. Assumimos que sempre há uma articulação e hibridismo, mas buscamos perceber se essa articulação ou determinadas formas de discurso ressaltavam nas diferentes atividades.

Analisamos também aspectos mais específicos dos processos de leitura e escrita. Em relação ao processo de leitura, a categoria Tipos de atividades de 
leitura define a forma como a leitura ocorre e pode ser individual - cada estudante tentando ler o texto sozinho -, realizada pela professora, ou coletiva, com cada estudante lendo uma parte do texto em voz alta. Além disso, também foram categorizadas estratégias sócio-cognitivas de leitura que apareceram nas atividades pedagógicas das aulas de Ciências. As estratégias em atividades de leitura incluíram a análise do título do texto lido, que se refere ao diálogo sobre o título do texto, antes dele ser lido efetivamente; a discussão do conteúdo do texto antes da leitura, ou seja, diálogo sobre o tema a que se refere o texto, antes de lê-lo; a discussão do sentido de termos, que diz respeito à explicação do significado de palavras que aparecem no texto; e finalmente a discussão ao longo da leitura, na qual a professora faz comentários sobre o texto enquanto ele é lido. A criação destas categorias é baseada em Koch e Elias (2015), em uma perspectiva sociointeracionista da linguagem. As estratégias que observamos se referem a processos e formas de mobilização de sistemas de conhecimento que permitem que um leitor participe de uma interação com o texto (e o seu autor). A partir dessas estratégias que foram realizadas nas atividades pedagógicas, pudemos entender como a professora atuava na possibilidade dos estudantes darem sentido aos textos que liam. Assim, essas categorias nos permitiram interpretar aspectos mais específicos da atuação das professoras de Ciências sobre a atividade de leitura dos alunos.

Em relação à escrita, também classificamos os tipos de atividades de escrita que apareceram, nos referindo à maneira como a produção textual acontece em atividades pedagógicas de aulas de Ciências: se é uma escrita individual - cada estudante criando seu texto -, se é uma escrita no quadro a partir de discussão, isto é, se é elaborada coletivamente a partir de um diálogo entre a professora e a turma e depois colocada no quadro, ou ainda se a professora cria sozinha o texto e os estudantes só copiam (cópia) ou escrevem a partir do que a professora dita (ditado). Da mesma forma que fizemos com as atividades de leitura, analisamos as estratégias em atividades de escrita. Estas são relativas a estratégias sóciocognitivas que são utilizadas para escrever, em uma concepção sociointeracionista da linguagem. De acordo com Koch e Elias (2017), no momento da escrita usamos variadas estratégias sócio-cognitivas que nos ajudam a interagir, através do texto, com o leitor imaginado e ativar os diferentes sistemas de conhecimentos que precisamos para desenvolver um texto. As estratégias categorizadas para a escrita 
incluíram a discussão de dúvidas ortográficas (discussão de ortografia), discussão de conteúdo antes de realizar a atividade de escrita e discussão do solicitado em atividades de escrita, que se refere ao que é pedido nas questões escritas (o objetivo da produção textual).

Por fim, ainda para a análise das atividades de escrita, categorizamos as atividades de acordo com o estímulo à autoria. Optamos por incluir essa categoria apenas em relação à escrita e não à leitura, visto que a maioria de atividades de leitura que observamos foram mediadas pelas professoras, sendo difícil percebê-las como autônomas ou autorais, no sentido de serem conduzidas pelos alunos. Essa categoria em relação à escrita diz respeito ao fato da produção textual demandar autoria dos estudantes ou não. Em uma perspectiva bakhtiniana, textos autorais seriam aqueles nos quais o estilo do autor aparece mais, no qual ele consegue expressar mais sua forma de escrever, o seu "eu-autor". Claro que nessa concepção, toda enunciação é autoral, afinal é produzida por determinado sujeito que é autor do seu discurso, quando enunciado em interações sociais concretas. Assim, numa visão geral, podemos dizer que toda produção textual (sendo discursiva) é de alguma maneira autoral. Porém, algumas produções permitem que se perceba mais essa autoria, ao propiciarem mais o aparecimento da individualidade. Nesse sentido, determinadas formas possibilitam mais autoria que outras. As propostas de escrita foram então classificadas como autorais (que possibilitam maior expressão do estilo do aluno), não autoral (texto controlado, que limita os sentidos possíveis e a aparição do estilo individual) ou híbrido, quando a produção textual proposta leva a uma expressão de estilo limitada.

A codificação das unidades de análise, isto é, a classificação nas subcategorias descritas, foi testada, para estudo da confiabilidade dos códigos criado. Para isso, inicialmente treinei duas pesquisadoras do grupo de pesquisa, explicando os objetivos da investigação, os sentidos estabelecidos para cada código criado e fazendo junto com elas a codificação de uma aula no ATLAS.ti. Trabalhamos juntas com uma das aulas observadas, utilizando o software. Essa aula estava com as unidades de análise marcadas. Codificamos essas unidades juntas, em um exercício de formação para o uso dos códigos possíveis (as subcategorias). Assim, junto com as pesquisadoras do grupo, fomos olhando as atividades pedagógicas que tinham ocorrido nessa aula e classificando-as de acordo com o tipo de atividade, a tradição curricular na qual se inseriam, o enfoque do currículo que 
expressavam, se era uma atividade de leitura e/ou escrita, que tipo de leitura e/ou escrita demandava, que estratégias eram realizadas e que gêneros discursivos apareciam. Depois, separadamente cada uma delas aplicaram esses mesmos códigos nas atividades pedagógicas (unidades de análise) de uma outra aula. Comparamos a aplicação de cada uma entre si e com a que eu havia feito antes. O percentual de concordância na aplicação dos códigos entre nós três foi de $85 \%$, o que confirmou a confiabilidade dos códigos criados. A ideia é que esse alto índice de concordância permite-nos supor que o significado dos códigos estava claro, diminuindo a influência da subjetividade da pesquisadora (sempre presente). A seguir, descrevemos outra fonte importante para produção de dados para a pesquisa, a análise dos materiais didáticos utilizados.

\section{2.}

\section{Análise de materiais didáticos}

Outra fonte de dados para a pesquisa foram os materiais didáticos usados nas aulas de Ciências observadas. A análise desses materiais foi importante para o estudo dos textos através dos quais as interações ocorriam nas atividades pedagógicas de Ciências, comparando com os dados produzidos nas observações e trazendo informações complementares. Em uma perspectiva bakhtiniana, esses materiais didáticos foram compreendidos como produtos de atividades sociais articuladas a contextos particulares de produção, circulação e interação de sujeitos participantes de práticas discursivas dialógicas. Nesse sentido, não olhamos para eles apenas como suporte de conteúdos da disciplina escolar Ciências, mas como produto e produtores de linguagem, conhecimentos específicos e interações sociais, ao se constituírem como participantes de práticas sociais discursivas concretas que acontecem no espaço escolar. Assim, julgamos importante não só analisar os conteúdos dos materiais didáticos, mas também a forma como são mobilizados nas aulas de Ciências.

Estudamos os textos dos materiais didáticos como materialidade dos discursos, pensando sobre as condições de produção discursiva nas salas de aula observadas. Não pudemos analisá-los no momento do uso dos textos em si (momentos da enunciação). Mas, ao realizar a análise, refletimos sobre os momentos de interação com esses textos que havíamos observado em aula. Como 
articulamos a análise dos textos a reflexões sobre seu uso, estudamos apenas os materiais com as quais observamos as professoras realizando atividades pedagógicas envolvendo leitura e/ou escrita. Os materiais analisados incluíram: i) os Cadernos Pedagógicos de Ciências dos $3^{\circ}$ e $4^{\circ}$ bimestres do sexto ano do ensino fundamental de 2016; ii) um roteiro de aula prática de experimentação; iii) avaliações realizadas pelos estudantes e iv) um estudo dirigido elaborado por uma das professoras.

O principal material didático utilizado nas aulas observadas foram os Cadernos Pedagógicos de Ciências do sexto ano do ensino fundamental de 2016, dos $3^{\circ}$ e $4^{\circ}$ bimestres, elaborados pela Coordenadoria de Educação da Secretaria Municipal de Educação do Rio de Janeiro (COORDENADORIA DE EDUCAÇÃO DO RIO DE JANEIRO, 2016 a e b). O Caderno Pedagógico do $3^{\circ}$ bimestre tinha como conteúdo temático a atmosfera terrestre, e o do $4^{\circ}$ bimestre, Ecologia.

Além dos Cadernos Pedagógicos, analisamos um roteiro de experimentação usado em uma das aulas com experimentos observadas. A aula envolveu a montagem de terrários para discussão do tema ecossistema. $\mathrm{O}$ roteiro e a proposta da aula foram desenvolvidos pela licencianda de Ciências Biológicas da UFRJ que acompanhava as aulas de Ciências na Escola 3, orientada pela professora regente e pela professora de Prática de Ensino da universidade. Escolhemos analisar este roteiro, pois foi o único que observamos em uso em uma das aulas. Outras atividades com experimentação foram observadas, mas foram feitas a partir de propostas dos Cadernos Pedagógicos. Tivemos acesso também a outros roteiros de prática elaborados por uma das professoras. Porém, apenas observamos em uso esse roteiro do terrário.

Analisamos ainda duas avaliações escritas formais que os alunos realizaram em aulas observadas, uma prova elaborada pela Secretaria Municipal de Educação do Rio de Janeiro, que funciona como uma avaliação externa, e uma prova elaborada por uma das professoras que participaram da pesquisa, uma avaliação interna. Essa análise foi desenvolvida comparativamente. Observamos outras aulas com a realização de provas, mas por uma questão de saturação, não analisamos todas essas provas. A análise de uma avaliação externa e de uma avaliação interna foi suficiente para discutir os processos que julgamos mais importantes, especialmente em relação à leitura e/ou à escrita. 
Por fim, analisamos um estudo dirigido, que representou outros materiais observados em aulas de Ciências que envolveram trabalhos de leitura e/ou escrita. Ele foi estudado como exemplo de um material elaborado por uma das professoras para o desenvolvimento do trabalho pedagógico.

Além destes, outro material que apareceu nas aulas observadas foi o caderno dos alunos, no qual copiavam textos do quadro que as professoras desenvolviam e faziam exercícios escritos. Não tivemos acesso a estes cadernos, por isso não pudemos analisa-los profundamente, mas atividades desenvolvidas com este material apareceram ao longo das análises das observações.

A unidade de análise dos materiais didáticos é constituída pelos textos (escritos ou imagéticos) utilizados nas atividades pedagógicas observadas. Algumas categorias de análise foram semelhantes às utilizadas nas observações ou bem parecidas com estas, permitindo a análise conjunta dos dados (QUADRO 5).

QUADRO 5 - Categorias e subcategorias usadas na análise dos materiais didáticos utilizados em atividades pedagógicas com leitura e/ou escrita das aulas de Ciências.

\begin{tabular}{|c|c|}
\hline Categorias & Subcategorias \\
\hline \multirow{4}{*}{$\begin{array}{l}\text { Material utilizado na atividade } \\
\text { pedagógica }\end{array}$} & Caderno Pedagógico \\
\hline & Roteiro de experimentação \\
\hline & Avaliação formal \\
\hline & Outros (caderno, livro didático, estudo dirigido) \\
\hline \multirow{3}{*}{$\begin{array}{l}\text { Finalidades ou tradições } \\
\text { curriculares do ensino de } \\
\text { Ciências }\end{array}$} & Tradição acadêmica \\
\hline & Tradição utilitária \\
\hline & Tradição pedagógica \\
\hline \multirow{5}{*}{$\begin{array}{l}\text { Enfoques curriculares do ensino } \\
\text { de Ciências }\end{array}$} & História Natural \\
\hline & Ecologia \\
\hline & Fisiologia, anatomia e saúde humanas \\
\hline & Ciência e experimentação \\
\hline & Vida cotidiana \\
\hline \multirow{3}{*}{ Autoria } & Texto autoral \\
\hline & Autoria híbrida \\
\hline & Texto não autoral \\
\hline
\end{tabular}

Dentre as categorias para análise dos materiais, semelhantes às criadas para as observações, incluímos o tipo de material utilizado, que se relaciona à atividade 
pedagógica realizada. Estes materiais foram classificados como Caderno Pedagógico, roteiro de experimentação, avaliações formais (provas) ou outros, como o estudo dirigido observado.

Estudamos também as tradições curriculares do ensino de Ciências que estavam expressas nos textos dos materiais, classificadas em tradições acadêmicas (relacionadas ao saber de referência acadêmico), utilitárias (associada aos conhecimentos cotidianos dos estudantes) ou pedagógicas (relativas às diferentes formas de aprendizagens), de acordo com Goodson. Conforme desenvolvemos anteriormente na descrição das categorias da análise das observações. Pesquisamos também os enfoques curriculares nos quais os textos estavam inseridos, baseadas em Gomes (2008). Assim, interpretamos se os textos traziam elementos de descrições que os aproximam da história natural; se a temática dos textos nos materiais se referia a conhecimentos ecológicos ou discussões relativas à educação ambiental, do enfoque ecologia; se abordavam elementos do corpo humano e questões de saúde, do enfoque anatomia, fisiologia e saúde humanas; ou ainda se diziam respeito a questões da vida cotidiana; e finalmente se tinham relação com a ciência e a experimentação.

A análise incluiu ainda as perguntas que os materiais traziam nos exercícios escritos, buscando perceber que tipo de demanda de produção textual era solicitada em relação à autoria, se era autoral, não autoral ou ainda se permitia uma autoria híbrida, refletindo sobre a possibilidade de aparecimento do estilo do autor, conforme discutimos anteriormente.

Para análise dos materiais, não consideramos as categorias utilizadas nas observações que dependiam efetivamente de como as atividades aconteciam, não sendo possível estudá-las nos materiais, como, por exemplo, as estratégias e os tipos de atividades de leitura e de escrita. Além disso, não incluímos as categorias gêneros discursivos primários e secundários, visto que como os materiais são escritos e não produzidos em situações imediatas de comunicação, entendemos que traziam apenas gêneros discursivos secundários. Para análise dos gêneros do discurso que aparecem nos textos dos materiais (especialmente nos Cadernos Pedagógicos), buscamos analisar com mais profundidade os gêneros discursivos secundários, criando uma classificação de tipos mais específicos destes gêneros. Estes são apresentados no próximo capítulo, como parte dos resultados da 
investigação. Para continuar a descrição das fontes analisadas para produção de dados, discutimos as entrevistas desenvolvidas.

\section{3.}

\section{Entrevistas com professoras e estudantes}

Entrevistas realizadas com as professoras de Ciências e grupos de estudantes, cujas aulas foram observadas, constituíram outra fonte de dados importante para a pesquisa. A entrevista é uma técnica que vem sendo utilizada em pesquisas sociais para coleta de dados de caráter subjetivo, pois “destaca o sujeito, que tem um papel fundamental no processo de investigação ao interpretar os fenômenos atribuindo-lhes significado" (OLIVEIRA et al, 2010, pg. 25). Nesse sentido, as entrevistas foram utilizadas para o estudo das concepções das professoras e estudantes sobre leitura e escrita e suas percepções sobre as relações destes processos com as aulas de Ciências.

As entrevistas foram feitas com as professoras e grupos de estudantes no final do ano letivo de $2016^{30}$, depois que as observações tinham sido realizadas. Para Lüdke e André (1986), uma das principais vantagens da entrevista é a possibilidade de interação entre os sujeitos, pesquisador e pesquisado, sem que se estabeleça uma relação hierarquizada entre ambos. Na realização das entrevistas ao final do ano letivo, professoras e estudantes já me conheciam e se sentiram mais à vontade durante a entrevista. $\mathrm{O}$ modelo de entrevista utilizado foi o semiestruturado, isto é, com um roteiro de base, mas sem a imposição rígida e fechada de questões. A partir das respostas às questões da entrevista, adaptávamos novas perguntas, ou sugeríamos aprofundamentos necessários para investigação. Assim, havia um direcionamento das questões colocadas, através do roteiro, mas sem limitar a expressão mais livre dos entrevistados. Na realização das entrevistas, o objetivo da pesquisa foi novamente esclarecido e foram elaborados e assinados termos de consentimento pelas professoras e pelos responsáveis dos estudantes entrevistados. Além de termos de assentimento pelos próprios estudantes (APÊNDICE 1).

\footnotetext{
${ }^{30}$ Com exceção da entrevista com os grupos de estudantes da Escola 1, que foi realizada no início de 2017, devido à situação de violência vivenciada no final de 2016, que me afastou da escola, conforme explicitado anteriormente.
} 
O roteiro de entrevista das professoras é constituído por dois blocos (APÊNDICE 2). O primeiro integra perguntas sobre a formação docente. O segundo bloco se relaciona a perguntas mais específicas de como percebem questões relacionadas à leitura e à escrita em suas aulas, incluindo a relevância do trabalho, dificuldades associadas a ele, atividades que declaram realizar, textos trabalhados, dificuldades de leitura e/ou escrita dos estudantes, entre outros.

Os estudantes foram entrevistados em grupos, formados por aqueles que aceitaram participar e cujos responsáveis assinaram os termos de consentimento. Na Escola 1 foram entrevistados dois grupos de alunos, em um total de 10 estudantes entrevistados. Na Escola 2, dois grupos foram entrevistados, cada um deles constituído por 5 alunos (total de 10 estudantes entrevistados). Na Escola 3, apenas um grupo foi entrevistado, formado por 6 crianças. O roteiro de entrevista dos estudantes (APÊNDICE 3) incluiu perguntas para falarem sobre a escola e as aulas em geral (primeiro bloco), e um segundo bloco sobre leitura e escrita, com questões específicas associadas às aulas de Ciências. Em relação às perguntas sobre as aulas de Ciências, se referiam às dificuldades que sentiam, formas de leitura e escrita que aconteciam nas aulas, tipos de textos que acessavam, materiais, e mais especificamente, sobre a aprendizagem de leitura e escrita.

Todas as entrevistas foram audiogravadas e depois transcritas, para reprodução fiel do que os entrevistados falaram no momento da entrevista. Após as transcrições, as entrevistas foram analisadas. Para isso, fizemos uma leitura cuidadosa de exploração do material. Depois, realizamos novas leituras codificando os dados, com a criação de categorias de análise. A unidade de análise das entrevistas foram trechos de fala que tratavam de determinado assunto. As categorias de análise foram diferentes das categorias criadas para análise das aulas observadas e materiais didáticos, mas permitiram comparar os dados, pois estavam relacionadas às mesmas. As categorias das entrevistas das professoras estão descritas no quadro a seguir (QUADRO 6).

QUADRO 6 - Categorias e subcategorias usadas na análise das entrevistas com as professoras de Ciências.

\begin{tabular}{|l|l|}
\hline \multicolumn{1}{|c|}{ Categorias } & \multicolumn{1}{|c|}{ Subcategorias } \\
\hline \multirow{2}{*}{ Dados pessoais } & Formação \\
\cline { 2 - 2 } & Trajetória docente \\
\cline { 2 - 2 } & Atividade docente atual (em 2016) \\
\hline
\end{tabular}




\begin{tabular}{|c|l|}
\hline \multirow{2}{*}{ Concepções de leitura e de escrita } & Foco no texto \\
\cline { 2 - 2 } & Foco no sujeito \\
\cline { 2 - 2 } & Foco na interação \\
\hline \multirow{2}{*}{$\begin{array}{c}\text { Tipos de atividades pedagógicas } \\
\text { associadas à leitura e à escrita }\end{array}$} & Experimentação \\
\cline { 2 - 2 } & Pesquisa escolar \\
\cline { 2 - 2 } & Avaliação \\
\cline { 2 - 2 } $\begin{array}{c}\text { Formas de trabalho com leitura e } \\
\text { escrita }\end{array}$ & Outras atividades \\
\cline { 2 - 2 } & Organização das atividades \\
\hline \multirow{2}{*}{$\begin{array}{c}\text { Dificuldades associadas ao ensino- } \\
\text { aprendizagem de leitura e escrita }\end{array}$} & Formação docente \\
\cline { 2 - 2 } & Falta de autonomia leitura e escrita \\
\cline { 2 - 2 } & Dificuldades estruturais \\
\cline { 2 - 2 } & Críticas aos materiais \\
\cline { 2 - 2 } & Dificuldades dos alunos \\
\hline
\end{tabular}

A primeira categoria se refere aos dados pessoais das professoras que participaram da investigação, relacionados as suas histórias de vida como docentes de Ciências. A categoria se divide na subcategoria formação, que diz respeito à universidade na qual fizeram a graduação e em que ano terminaram, atividades acadêmicas que realizaram durante o curso (como estágios com bolsas de iniciação científica, monitorias, etc.), cursos de pós-graduação realizados, participação em grupos de pesquisa, entre outros. Outra subcategoria analisada é a de trajetória docente, que inclui todas as atividades que realizaram como professoras. Por fim, há a subcategoria atividade docente atual, que diz respeito às atividades profissionais que realizavam na época do campo empírico.

As concepções de leitura e de escrita se basearam em Koch e Elias (2015 e 2017). A concepção de leitura e de escrita com foco no texto se relaciona a ideia de língua como um sistema de códigos fechado e acabado. O texto é entendido como um produto de uma codificação realizada pelo escritor (autor) a ser decodificado pelo leitor. Para isso, é apenas necessário que ambos conheçam o código utilizado. Assim, na pesquisa, as falas das professoras que se aproximavam da concepção da leitura e de escrita com foco no texto eram aquelas que valorizavam apenas a estrutura da língua na leitura e na escrita, que consideravam que ensinar e aprender a ler e/ou escrever se referia apenas ao domínio de regras 
gramaticais da língua e de certo vocabulário. Já a compreensão dos processos de leitura e de escrita com foco no sujeito pressupõe o texto como um produto lógico do pensamento. $\mathrm{O}$ leitor, para compreender um texto, precisaria apenas entender as intenções e ideias do autor, expressas no material. Nas entrevistas, essa concepção aparece quando as docentes pensam sobre os sujeitos que leem e escrevem, enaltecendo a ação dos estudantes na captação do que está no texto ou na expressão do próprio pensamento. O foco na interação traz a ideia de que no processamento textual há uma interação entre autor, texto e leitor. O autor e o leitor são sujeitos sociais ativos. Nesse contexto, a leitura seria um processo complexo de produção de sentidos que depende das experiências e dos conhecimentos do leitor, além das sinalizações do texto. Assim, o sentido não está só no autor (foco no sujeito) ou só no texto (foco no texto), mas na interação autor-texto-leitor. Nessa concepção, para escrever, o autor precisa ativar várias estratégias sócio-cognitivas, que incluem o conhecimento dos elementos linguísticos e sua forma de organização, mas também a mobilização do que pressupõe que sejam os conhecimentos do leitor. Entendemos a ocorrência desta subcategoria nas falas das professoras, quando elas mencionavam interações sociais que os estudantes vivenciavam na leitura e na escrita.

As professoras também comentaram nas entrevistas diferentes tipos de atividades pedagógicas das aulas de Ciências associadas à leitura e/ou escrita. Elas trouxeram reflexões sobre atividades que já realizaram em suas práticas nas quais reconhecem possibilidades de acontecerem diferentes etapas de processos de ensino-aprendizagem de leitura e de escrita. Entre estas, mencionaram a experimentação, pesquisa escolar, avaliação escolar (provas) e outros, como uso de vídeos e trabalhos com outras fontes, como a Revista Ciência Hoje das Crianças.

A categoria formas de trabalho com leitura e escrita, diz respeito às maneiras pelas quais as professoras declararam organizar as atividades pedagógicas que envolviam linguagem escrita e as estratégias para leitura e escrita que utilizavam. Dessa forma, incluiu falas que diziam como a leitura era realizada em sala e como as demandas de produção textual apareciam (organização das atividades). Ou ainda, reflexões sobre tipos de processos que desenvolvem na leitura e escrita, discussão de sentidos de palavras, orientação para escrita, etc. (Estratégias para leitura e escrita). 
Nas entrevistas, apareceram ainda reflexões sobre dificuldades associadas a processos de ensino-aprendizagem de leitura e de escrita nas aulas de Ciências. As professoras discutiram bastante sobre a falta de autonomia para a realização das atividades pedagógicas, associada ao contexto de controle do trabalho docente que estavam vivenciando nas escolas municipais. Em relação à categoria dificuldades, trouxeram ainda reflexões sobre a formação docente, sobre a falta de materiais, falta de espaços físicos para leitura, etc. (dificuldades estruturais) e sobre a qualidade dos materiais didáticos disponíveis (críticas aos materiais). Fizeram também longos comentários sobre as dificuldades dos alunos em relação às atividades de leitura e de escrita e no que se refere aos seus contextos sociais de vida.

As categorias para análise das entrevistas dos alunos foram parecidas com as das professoras, mas algumas foram excluídas por tratarem especificamente de processos de ensino (relativos às docentes) e outras foram adaptadas para compreensão de falas referentes às vivências dos alunos (QUADRO 7):

QUADRO 7 - Categorias e subcategorias usadas na análise das entrevistas com os grupos de estudantes do sexto ano do ensino fundamental.

\begin{tabular}{|c|l|}
\hline Categorias & \multicolumn{1}{|c|}{ Subcategorias } \\
\hline \multirow{2}{*}{ Relação com a escola } & Disciplinas escolares \\
\cline { 2 - 2 } & Disciplina escolar Ciências \\
\hline Concepção de leitura e de escrita & Foco no texto \\
\hline $\begin{array}{c}\text { Tipos de atividades pedagógicas } \\
\text { associadas à leitura e à escrita }\end{array}$ & Experimentação \\
\cline { 2 - 2 } & Pesquisa escolar \\
\cline { 2 - 2 } & Avaliação \\
\cline { 2 - 2 } & Uso do Caderno Pedagógico \\
\hline \multirow{2}{*}{$\begin{array}{c}\text { Formas de trabalho com leitura e } \\
\text { escrita }\end{array}$} & Organização das atividades \\
\hline \multirow{2}{*}{$\begin{array}{c}\text { Dificuldades associadas ao ensino- } \\
\text { aprendizagem de leitura e escrita }\end{array}$} & Linguagem \\
\cline { 2 - 2 } & Críticas aos materiais \\
\hline
\end{tabular}

O primeiro bloco de perguntas com os estudantes se referiu à escola em geral. O objetivo era que se soltassem e se sentissem à vontade para começarem as falas de suas relações com a escola e com a disciplina Ciências. Os alunos falaram sobre as disciplinas que compõem a grade escolar, discutindo quais gostavam mais 
e porquê. Nesse momento, surgiram comentários mais específicos das aulas de Ciências, que traziam as motivações que vivenciavam nas aulas de Ciências (disciplina escolar Ciências).

Depois, nas discussões ao longo das entrevistas, as crianças colocaram suas impressões em relação às atividades de leitura e escrita das aulas de Ciências. Nas falas, transpareceram concepções de leitura e de escrita, que sempre apareceram com foco no texto, de forma que esta foi a única subcategoria utilizada na análise

Ao discutirem as aulas de Ciências, apareceram em suas falas vários tipos de atividades pedagógicas que acontecem nesse espaço-tempo escolar. Ao longo da entrevista falaram dessas atividades discutindo aspectos variados. Dentre estas, mencionaram experimentação, avaliação, pesquisa escolar e uso do Caderno Pedagógico.

Em relação às formas de trabalho com leitura e escrita nas aulas de Ciências, falaram sobre a organização das atividades pelas professoras. Assim, discutiram como as suas professoras organizavam as relações com os textos. Se elas pediam que eles lessem, que tipo de atividades de escrita solicitavam, como usavam os materiais para ler e escrever, etc.

Nas entrevistas dos grupos de alunos, pudemos ainda estudar as dificuldades que eles declaravam possuir quando liam e escreviam nas aulas de Ciências (dificuldades associadas ao ensino-aprendizagem de leitura e escrita). Estas se associaram a questões de linguagem, especialmente em reflexões sobre termos específicos do campo lexical científico, e outras relativas aos materiais.

As análises das diferentes fontes de dados (entrevistas, materiais didáticos e observações de aulas) foram comparadas, construindo relações entre os resultados. A partir disso, interpretamos o fenômeno em estudo, isto é, as relações estabelecidas entre as atividades de leitura e escrita e as aulas de Ciências. No próximo capítulo apresentamos os resultados das análises realizadas. 


\title{
4 \\ Leitura e escrita na disciplina escolar ciências
}

\author{
"Porque de certa forma eu fiz ali um \\ trabalho de leitura, de reflexão, tirei \\ dúvidas. Então eles já estavam mais ou \\ menos preparados para escrever".
}

(Fala de uma das professoras de Ciências que participaram da pesquisa).

A visão dialógica do mundo na perspectiva bakhtiniana me ajudou a pensar sobre a escola, as aulas de Ciências e suas relações com a linguagem escrita. O diálogo unifica todas as atividades humanas, posto que sempre se realizam através da linguagem, em interações discursivas inevitavelmente dialógicas. A própria natureza da linguagem é constituída pelo diálogo, compreendido em um sentido mais amplo, como toda e qualquer comunicação discursiva. Nas palavras de Bakhtin-Volochínov (1990, pg. 109):

O diálogo, no sentido estrito do termo, não constitui, é claro, senão uma das formas, é verdade que das mais importantes, da interação verbal. Mas pode-se compreender a palavra 'diálogo' num sentido amplo, isto é, não apenas como a comunicação em voz alta de pessoas colocadas face-a-face, mas toda comunicação verbal de qualquer tipo que seja.

Nesse sentido, o diálogo acontece como um encontro de manifestações discursivas que podem corroborar, se complementar, discordar, duelar entre si, se questionar, entre tantas outras possibilidades. Nas interações sociais entre sujeitos, o dialogismo aparece como um entrelaçamento de discursos, formados a partir de outros discursos, que por sua vez vieram de outros discursos. Nessa teia discursiva as interações acontecem e a vida se concretiza.

Nas observações realizadas, percebemos a escola como um espaço humano de interação social e linguagem, um espaço de natureza dialógica. Mais especificamente, analisando as aulas de Ciências entendemos que são constituídas através de diálogos e que muitos deles acontecem nas interações sociais entre os próprios estudantes e entre os mesmos e as professoras em momentos de processamento textual (seja de leitura ou de escrita). Assim, observamos que muitos diálogos se estabelecem nas aulas de Ciências através da leitura e/ou da escrita, construindo interações sociais que passam pela linguagem escrita e tornam as aulas de Ciências um espaço-tempo também para ler e escrever. 
Em todas as aulas observadas apareceram atividades de leitura e/ou escrita, nas quais interações sociais se estabeleceram através de textos. Isso significa que em todas as aulas encontramos uma ou mais unidades de análise que foram categorizadas e estudadas. Essas unidades, como discutido na seção de estratégias metodológicas, foram compostas por atividades pedagógicas que envolviam interações a partir da leitura ou da escrita de textos, incluindo todo diálogo que ocorria entorno destes (mesmo antes ou depois deles serem lidos ou escritos). As práticas de leitura e de escrita foram variadas, realizadas de diferentes maneiras, com objetivos e metodologias didáticas distintas, conforme discutiremos posteriormente. Destacamos que, apesar de as professoras serem diferentes em suas práticas, as análises desenvolvidas não foram comparativas. As atividades que realizaram e as falas foram consideradas como um conjunto de práticas. Assim, não expusemos de quem era cada fala e nem a escola na qual cada atividade ocorreu, entendemos como um todo as diferentes possibilidades de se trabalhar a leitura e a escrita no ensino de Ciências.

Percebemos que em todas as aulas interações com textos escritos ocorreram e foram sempre centrais para os processos pedagógicos desenvolvidos. Isso não significa que em todas as aulas ocorreram processos de reflexão mais específicos sobre leitura e/ou escrita. Muitas vezes, a linguagem escrita era naturalizada nas aulas (e não problematizada), como se as crianças desse nível de escolaridade já soubessem naturalmente ler e escrever. Nas palavras de duas das professoras investigadas "A gente que trabalha do sexto ao nono ano, a gente geralmente espera um aluno que já tenha essa formação. Então a gente espera um aluno que venha do quinto ano sabendo ler e escrever perfeitamente. Pontuação, acentuação... Mas, não é muito essa a realidade, não é? Geralmente o aluno do sexto ano não chega com uma fluidez de texto" e "A gente espera que o aluno venha com uma escrita e leitura já prontas. (...) então a gente esperava que já viessem bem alfabetizados. Infelizmente não vem”. As falas refletem a naturalização da capacidade de ler e/ou escrever dos estudantes que muitas vezes as professoras mostram nas aulas de Ciências. Por outro lado, ao perceberem que essa não é a realidade de seus alunos e destacarem suas dificuldades, expressam que é preciso ainda ensinar a ler e a escrever.

O reconhecimento pelas professoras da necessidade do trabalho com ensinoaprendizagem de leitura e escrita e a ocorrência de atividades envolvendo esses 
processos em todas as aulas enaltece o papel que o ensino de Ciências pode adquirir na formação de leitores e escritores. Assim, colocamo-nos ao lado de autores que defendem as aulas de Ciências como espaço importante para práticas de leitura e escrita, como o fazem, por exemplo, Silva (1998); Souza (2000); Cassiani-Souza e Almeida (2005); Salomão (2005); Lopes e Dulac (2011); e Cassiani-Souza et al (2012), entre outros.

Para aprofundar as reflexões nesse sentido, buscamos nessa pesquisa compreender de que forma a relação entre a disciplina escolar Ciências e a linguagem escrita se estabelece nas aulas, e ainda, de que forma os sujeitos que constroem essa relação olham e pensam sobre ela. Para isso, na próxima seção, discutimos as concepções de leitura e de escrita das docentes e alunos que participaram da investigação. Analisamos também a forma como percebem as interações construídas na disciplina Ciências a partir da linguagem escrita. Posteriormente, descrevemos mais detalhadamente como o dialogismo e a mediação em torno dos textos se estabelecem nas aulas. Na última seção do capítulo, abordamos estratégias de ensino-aprendizagem de leitura e escrita que foram observadas em diferentes atividades pedagógicas das aulas de Ciências, destacando seus potenciais e limites.

\section{1. \\ Professoras e estudantes: relações e sentidos sobre leitura e escrita nas aulas de Ciências}

"Mas eu não sei falar isso escrevendo".

(Fala de um estudante do sexto ano do ensino fundamental, de acordo com uma das professoras da pesquisa)

Para entender os processos de leitura e escrita que ocorrem nas aulas de Ciências, parece-nos importante começar refletindo sobre como os sujeitos que leem e escrevem percebem o que significa ler e escrever, isto é, que concepções trazem e que sentidos atribuem aos processos de leitura e escrita.

Inicialmente, destacamos que as professoras de Ciências que participaram da pesquisa reconhecem a centralidade de atividades de leitura e escrita em suas aulas: 
Então acho que é o principal. Operações básicas de matemática, que fazem parte da vida deles, e a leitura também. As aulas de ciências, assim sem a leitura e sem a escrita não funcionam. Eles não têm a compreensão e tal. E por isso que assim toda... quase toda a minha aula tem uma coisa escrita. (...). Eu acho que é importante ter bastante coisa para ver se com alguma dessas eles fixam. Mas é essencial. Se eles não souberem ler, interpretar e escrever, falta tudo. Falta para todas as disciplinas, não só em Ciências. (Fala de uma das professoras investigadas).

$\mathrm{Na}$ fala destacada percebemos que a professora enaltece a importância da leitura e da escrita e destaca como são atividades sempre presentes em suas aulas. Sua fala traz a reflexão especialmente sobre o papel dessas atividades no ensinoaprendizagem de conteúdos de Ciências e não especificamente sobre a formação para leitura e escrita. A leitura e a escrita nesse caso funcionam para aprendizagem de conteúdos científicos, nas palavras da professora, para acessar informação, para fixar algum conteúdo. Porém, mesmo que o foco da fala da professora esteja nos conteúdos de Ciências, percebemos que há também um reconhecimento da importância de leitura e de escrita na própria cultura escolar ("Falta para todas as disciplinas, não só em Ciências") e na vida dos estudantes (“que fazem parte da vida deles").

Outra professora investigada também destaca a centralidade da leitura e da escrita nas suas aulas ao colocar que confere os materiais escritos dos alunos e analisa como estão produzindo seus textos.

(...) eu também tenho o costume de conferir o caderno deles. Dou visto no caderno em todas as aulas e ao final do bimestre eu recolho os cadernos e confiro. Aí nisso eu consigo ver se o aluno copia bem, se ele, na resposta dos exercícios, das atividades, ele está escrevendo legal. O que eu costumo fazer no sétimo ano, se eu percebo que tem um aluno com muita dificuldade de escrita, eu converso com o professor de português da turma. (...).Eu falo: olha ele não escreve legal e tudo mais. Porque é o professor de português que consegue avaliar melhor. $\mathrm{O}$ aluno escreve redação, faz mais textos de interpretação e tudo mais, então ele consegue avaliar melhor. Eu no primeiro e no segundo bimestre eu fiz uma listagem e passei pra coordenadora, falei dos alunos que não estavam... assim até alunos semianalfabetos ou que escreviam muito mal, interpretavam muito pouco, para ela encaminhar para o reforço. Porque chegou uma professora de português aqui quarenta horas e ela estava dando reforço para os alunos. (Fala de uma das professoras investigadas).

Nessa mesma fala, vemos que a professora descreve que ao se deparar com dificuldades dos alunos em leitura e/ou escrita procura professores de outra disciplina, que segundo ela estariam melhor preparados para lidar com essas questões. Dessa forma, diminui o papel de docentes de Ciências no ensinoaprendizagem desses processos. Por outro lado, ao declarar que percebe e aponta as 
dificuldades para a professora de língua portuguesa ou para as aulas de reforço, se mostra corresponsável pela relação dos estudantes com a linguagem escrita. A própria comunidade escolar identifica na professora de Ciências alguém que trabalha com leitura e escrita e, portanto, percebe estudantes com mais dificuldades. Eu um dia de observação na sala dos professores desta escola, assistimos a uma reunião entre a coordenadora pedagógica da escola e a professora de Ciências, mencionada pela professora na fala anterior. Tal observação mostrou que a coordenadora reconhece na professora de Ciências alguém para dialogar sobre as habilidades de leitura e de escrita dos alunos, como vemos na nota a seguir:

\begin{abstract}
Assisti na sala dos professores uma discussão entre a coordenadora pedagógica da escola e a professora de Ciências. Era uma discussão sobre aulas de reforço de leitura e escrita para o sexto e sétimo ano. Os alunos receberão aula com a própria coordenadora (pedagoga) e com a nova professora de português da escola no contra turno. A coordenadora consultou a professora de Ciências com uma lista de todas as turmas, discutindo que alunos ela indicaria para participarem das aulas de apoio. (Notas de diário de campo).
\end{abstract}

No trecho da entrevista abaixo, destacamos também o entendimento de atividades de leitura e de escrita como centrais nas aulas de Ciências. Nele a professora coloca como está sempre refletindo de alguma forma sobre a linguagem escrita em seu fazer pedagógico.

Sempre que eu penso em falar, eu estou pensando também em leitura e escrita porque o cara vai ter que pegar aquilo e extrair a informação e depois no exercício vai ter que passar pro papel de qualquer forma. (Fala de uma das professoras investigadas).

As falas das professoras, indicando a centralidade dos processos de leitura e escrita em suas aulas, remetem às reflexões sobre a relação entre a linguagem escrita e a escola. Nogueira (2013), baseado em discussões da Sociologia da Educação desenvolvidas por Lahire, reflete sobre o papel da escrita na produção do sucesso ou fracasso escolar e coloca que a linguagem escrita é elemento central da cultura escolar. Segundo Lahire, a linguagem escrita funciona no espaço escolar não apenas como instrumento de registro ou transmissão do conhecimento, mas principalmente como base de organização do pensamento e da realidade prática. Em diálogo com o autor, reconhecemos que a escola constitui seus saberes principalmente a partir da elaboração da linguagem escrita, como colocado pelas professoras. Isso reforça o argumento de que as aulas de Ciências, além de serem 
um espaço para refletir sobre o conhecimento científico escolar, são também um espaço de leitura e de escrita.

Os alunos também veem as aulas de Ciências como um espaço de ensinoaprendizagem de leitura e de escrita:

1) Estudante $A^{31}$ : Porque sempre que a gente tá estudando assim qualquer tipo de matéria, a gente tá aprendendo... (...). Aprendendo a ler e a escrever. (Grupo de alunos de uma das escolas investigadas).

2) Estudante A: Todas as aulas, todas as aulas ajuda a ler e a escrever também. (...) a gente vai aprendendo várias coisas sobre isso, vai aprendendo palavras novas, vai aprendendo a ler mais... (Grupo de alunos de uma das escolas investigadas).

3) Estudante A:Sim, ajuda a entender um monte de coisas.

Estudante B: É, porque tem as palavras difíceis. (Grupo de alunos de uma das escolas investigadas).

4) Estudante A: Ciências ajuda um pouquinho também.

Estudante B: Ciências um pouquinho, mas português é mais.

Estudante C: Português é mais para isso! (Grupo de alunos de uma das escolas)

Nas últimas falas, percebemos que os alunos entendem as aulas de Ciências como um espaço que ajuda "um pouquinho" a aprender a ler e escrever, mas destacam as aulas de Português como espaço principal de aprendizagem de leitura e de escrita, como normalmente se reconhece na escola. Porém, nas demais falas, percebemos a valorização das aulas de Ciências como um lugar para também aprender a ler e a escrever.

Em relação à percepção da frequência de atividades com leitura e escrita nas aulas de Ciências, a impressão dos alunos varia, dependendo da escola do grupo entrevistado. Alguns colocaram que há muito trabalho com textos, outros disseram que não. A impressão dos alunos nem sempre foi condizente com o que observamos na pesquisa. Apesar de acontecerem trabalhos com textos em todas as aulas observadas, nem todos os alunos acham que há muito para ler e/ou escrever. Talvez

\footnotetext{
${ }^{31}$ Os estudantes foram nomeados com letras, apenas para diferenciá-los dentro de cada diálogo. Assim, cada letra corresponde a um estudante diferente que estava falando. Mas em diálogos diferentes, não necessariamente estudantes com a mesma letra são os mesmos.
} 
isso se relacione ao fato de compararem com outras disciplinas que vivenciam na escola:

1) Estudante A: Às vezes ela faz assim, dois textos na apostila, mais um texto da apostila e um segundo que ela passa no quadro.

Estudante B: Mais um texto para copiar e um dever de casa para gente fazer sobre os textos. (Grupo de alunos de uma das escolas investigadas).

2) Pesquisadora: Vocês acham que têm muita coisa para ler nas aulas de Ciências?

Estudante A: Não. Só um pouco. (Grupo de alunos de uma das escolas investigadas).

3) Estudante A: Escrever é uma coisa que tem pouco na aula de Ciências... (Grupo de alunos de uma das escolas investigadas).

4) Estudante B: Porque aí você tem a apostila. Aí sempre tem que ler alguma coisa.... (Grupo de alunos de uma das escolas investigadas).

5) Estudante A: Tem muita coisa pra escrever. Quando a (...) resolve querer escrever...

Estudante B: Pra ler é pouco, mas para escrever quando ela quer escrever... (Grupo de alunos de uma das escolas investigadas).

As impressões sobre a frequência de atividades de leitura e de escrita nas aulas de Ciências podem estar associadas também às concepções dos estudantes sobre o que significa ler e escrever. A seguir, discutimos suas concepções de leitura e de escrita, assim como as das professoras.

\subsection{1.}

\section{Concepções de leitura e escrita dos estudantes e das professoras}

A análise das respostas dos alunos nas entrevistas mostrou que as crianças possuem concepções sobre leitura e escrita que não consideram os múltiplos aspectos que fazem parte destes processos.

1) Estudante A: Escrever eu não sei muito bem porque minha letra é horrível. Minha letra é feia. (Grupo de alunos de uma das escolas investigadas).

2) Estudante A: Agora, eu tava vendo umas coisas que eu escrevi ano passado... Meu Deus! Ao invés de escrever cantar, escrevi cartar, tipo isso. Não dá!

Estudante B: Tipo, às vezes, na hora de escrever eu esqueço que é para colocar uma letra e eu coloco outra letra... Confundo tudo. 
Estudante C: Eu sou mais ou menos assim em escrever, mas em leitura eu... (faz um sinal de negativo com o polegar virado para baixo) Eu até escrevo rápido, mas minha letra é um horror.

Estudante B: Acho que eu sou mais ler, porque escrever, eu escrevo muito devagar. (Grupo de alunos de uma das escolas investigadas).

3) Estudante A: Porque, tipo assim, têm coisas ainda que a gente escreve errado. Sem acento essas coisas. (Grupo de alunos de uma das escolas).

4) Estudante A: Sim. Pra mim é pra melhorar a minha letra. E ler também. Para ler eu sou muito lento.

Estudante B: Pra mim é só escrever mesmo.

Estudante C: Ter a letra bonita assim...

Estudante D: A minha letra é horrorosa.

Estudante A: Escrever as palavras bonitas e escrever rápido. (Grupo de alunos de uma das escolas investigadas).

Nas respostas dos estudantes, percebemos que refletem sobre leitura pensando na rapidez que leem e em relação à escrita, se referem à forma da letra (letra feia ou bonita), à velocidade que escrevem e à correção ortográfica. O entendimento que possuem parece se aproximar mais da ideia de leitura como a capacidade de decifrar um determinado código e a escrita como a correta utilização desse código. Em diálogo com Koch e Elias (2015 e 2017), trariam o que as autoras chamam de concepção de leitura e escrita com foco no texto. Nesse sentido, a língua seria um sistema fechado e acabado, um instrumento de comunicação pronto, e o texto seria um produto desse sistema, codificado por um emissor (autor) e decodificado pelo leitor, que para isso precisa apenas ter conhecimento do código utilizado. Assim, ler seria uma atividade de reconhecimento do sentido das palavras e das estruturas que estão no texto. Tudo está dito no texto. Escrever seria a correta apropriação do sistema e suas regras, para que esteja claramente expresso no texto. $\mathrm{Na}$ fala dos estudantes, ler bem seria decifrar o código com mais rapidez e escrever bem seria apresentar correção ortográfica, usar o código com rapidez e possuir uma letra "bonita".

As concepções dos alunos parecem se afastar de visões com foco nos sujeitos (autor ou leitor), já que não refletem sobre expressão do pensamento ou intenções do autor do texto, e se afastam ainda mais do entendimento mais complexo que compreende a leitura e a escrita com foco na interação entre autortexto-leitor. Koch e Elias (2017) comentam que a visão de escrita com foco no texto é comum na escola "Se, em uma sala de aula, perguntarmos aos alunos o que 
pensam sobre a escrita, certamente, ouviremos que, para escrever - e fazê-lo bem -, é preciso conhecer as regras gramaticais da língua e ter um bom vocabulário (...)" (Koch e Elias, 2017, pg. 32). Destacam ainda que o modo como a escrita é entendida se associa à forma como se compreende a linguagem, o texto e o sujeito que escreve, o que influencia a maneira como se pratica e ensina a escrita "ainda que não tenhamos consciência disso" (Koch e Elias, 2017, pg. 32). Nesse contexto, é importante que a gente reflita sobre a concepção de escrita e leitura que tem se perpetuado na escola. $\mathrm{O}$ trabalho com as regras gramaticais e estruturas textuais faz parte do processo de ensino-aprendizagem da escrita e da leitura, mas a compreensão do que seja ensinar e aprender a ler e a escrever precisa ir além disso, e passa, principalmente, pelo entendimento da linguagem (escrita) como interação social, com a criação de espaços de dialogia através do texto escrito. Leal (2008) aponta em seus estudos que os processos escolares de ensino-aprendizagem da linguagem escrita, desde os primeiros anos, têm transformado textos em objetos fechados em si mesmo e não espaços responsivos e de interlocução. As concepções de leitura e escrita dos estudantes que participaram da pesquisa que desenvolvemos parecem refletir essa visão do que seja aprender a ler e a escrever. Destacamos ainda a fala de uma das alunas entrevistadas, que nos dá uma dica de como a leitura e a escrita têm sido concebidas na escola e reforça o argumento de que precisamos refletir mais profundamente sobre de que forma temos pensado sobre a linguagem escrita nos processos pedagógicos "Eu tenho vergonha de perguntar porque na antiga escola que en estudava, eu fui perguntar pra professora, professora o que que está escrito aqui? A professora disse: lê, lê que você vai entender".

Outra impressão associada à leitura e à escrita que apareceu na fala dos alunos diz respeito a práticas de leitura e de escrita relacionadas ao controle disciplinar. Essas falas parecem se afastar da ideia de ensino-aprendizagem de leitura e escrita mais dialógica e interativa, pois associam ler e escrever a um castigo e não à construção de linguagem através de trocas com o outro.

1) Estudante A: Quando ela está com raiva, aí ela bota para escrever muito.

Estudante B: Quando a gente começa a falar muito e a estressar ela, aí ela resolve escrever mesmo...

Estudante C: Já a professora de história nem precisa tá com raiva pra querer escrever muito! (Grupo de alunos de uma das escolas investigadas). 
2) Estudante A: Às vezes quando ela vê que a gente tá fazendo muita bagunça, ela vai lá e pede para alguém continuar.

Estudante B: Fala lê até tal lugar...

Estudante C: Mas ela pede mais para ler quando ela vê quem tá conversando. (Grupo de alunos de uma das escolas investigadas).

A análise das falas das professoras indica que mesclam diferentes concepções de leitura e escrita. Algumas falas indicam que compreendem esses processos com foco no texto, em outras trazem o foco no sujeito ou ainda na interação social. Destacamos, inicialmente, algumas falas das entrevistas que indicam concepções com foco no texto:

1) É copiar o texto. Tem sempre um texto sobre o conteúdo que eu dei e os exercícios. (Fala de uma das professoras investigadas).

2) Nas minhas avaliações eu tento avaliar não pela escrita do aluno. Eu corrijo erros de português, mas eu não uso isso como uma maneira de avaliação. Não tiro ponto do aluno que não escreve bem. Eu tento perceber se ele entendeu. (...) Então eu não uso a leitura, a escrita como método de avaliação. (...). (Fala de uma das professoras investigadas).

Nesses dois trechos, notamos sentidos sobre o que seja ler e escrever relacionados apenas ao código descrito no texto, que se expressam na valorização da cópia como atividade de escrita, na primeira fala, e à limitação sobre o que seja escrever bem a questões gramaticais e estruturais, na segunda colocação. A seguir, encontramos outras falas que também trazem concepções de leitura e escrita restritas a estrutura do texto (foco no texto):

1) Eu sempre gostei muito de ler e escrever. (...). E aí eu percebo já como professora que essa prática de leitura e escrita está cada vez mais complicada. Porque primeiro a gente vive num mundo já que tudo é computador, tudo é tecnologia. E as pessoas já não têm muito aquele incentivo para ler, muito menos escrever, é tudo teclado. E o que eu vejo também nos meus alunos, que eles não trazem essa cultura da leitura de casa. (Fala de uma das professoras investigadas).

2) Eu falo: você acabou de explicar para mim. Escreve o que você me falou. Ah, mas eu não sei escrever isso, eu não sei falar isso escrevendo. Eles explicam para mim falando, oralmente, mas eles não conseguem construir a resposta escrita. (Fala de uma das professoras investigadas).

Percebemos na primeira fala que ler e escrever com uso de tecnologia não é conceituado como leitura e escrita, desconsiderando aspectos sociais e históricos que fazem parte desses processos. Na segunda colocação, aparece ainda a compreensão de que a escrita é apenas uma expressão da fala. De acordo com Koch e Elias (2017), há uma continuidade entre a fala e a escrita, porém é importante 
considerar como esse continuum é construído para pensar sobre o ensinoaprendizagem da escrita. É necessário valorizar o caráter histórico-cultural constitutivo da linguagem, tanto oral quanto escrita, quando refletimos sobre letramento (GOULART, 2003). Assim, as concepções apresentadas não concebem os variados elementos que constituem os atos de ler e escrever, reduzindo a complexidade processual dessas atividades.

Em outros momentos, porém, as falas das professoras carregam concepções distintas sobre leitura e escrita, que consideram mais elementos para compreensão destas atividades:

1) (...) essa dificuldade de leitura dá para eles uma dificuldade de interpretação. Então assim, eu tenho muita dificuldade porque eu não gosto de fazer aquelas perguntas simples (...). Eu gosto que eles procurem interpretar, compreender qual é a importância (...). Qual a importância disso na sua vida... E essas são perguntas onde eles têm que entender o que está sendo perguntado. Não olhar em cima num texto e decorar alguma coisa. E isso traz uma dificuldade para eles, uma dificuldade para mim que não sei trabalhar com essa falta de interpretação, com essa falta de leitura. (Fala de uma das professoras investigadas).

2) Sim, dificuldades gerais, principalmente de interpretação... construir respostas, eles têm essa dificuldade, se expressar de forma escrita e principalmente de acentuação e pontuação. (Fala de uma das professoras investigadas)

3) A maioria sabe ler, mas não sabe dizer o que leu. Então eles não têm compreensão. Para eles é tipo um código. Eles falam aquele código ali, mas o que significa muitos, eu posso dizer assim, acho que a metade dos alunos que trabalham comigo eles não conseguem. É muita dificuldade. (Fala de uma das professoras investigadas).

Nas duas primeiras falas, as professoras se referem à interpretação dos textos, indicando que não é apenas a estrutura do texto em si que permite a sua leitura. Na terceira fala, aparece a ideia de criação de significado em relação à leitura. Outras falas também mostram uma concepção da linguagem escrita mais complexa, que não se restringe a estrutura do texto:

1) A escrita eu tento com exercícios que eles tenham uma escrita própria, que eles consigam falar com as palavras deles. (...) em alguns momentos eles precisam ler sozinhos para fazer uma compreensão própria. (Fala de uma das professoras investigadas).

2) Eu botei uma última questão para eles, bem simples, discursiva. Eles não responderam. Não faziam ou então quando escreviam eram umas coisas assim sem pé nem cabeça, assim para formar a frase, para você entender o que eles estão escrevendo... Não é pela caligrafia, é você entender a lógica ali das palavras. (Fala de uma das professoras investigadas). 
3) E aí a gente volta para aquela coisa da leitura e da escrita. Parece que tudo para eles é muito oral. Quando você fala, eles conseguem entender. Mas para passar para o papel... (Fala de uma das professoras investigadas).

4) Eu falei uma frase que é a resposta certa, eles colocam na íntegra aquilo ali. Mas na verdade eles não estão entendendo. Eles estão copiando o que eles estão escutando e copiando o que eles estão lendo. Eles não pensam, eles não refletem sobre aquilo. (Fala de uma das professoras investigadas).

Nessas falas percebemos que as professoras entendem que escrever não é simplesmente copiar um código, não é apenas uma questão gramatical e envolve de alguma forma a expressão do autor. Nesses trechos vemos que não consideram apenas o texto em si, mas também os sujeitos envolvidos nos processos de leitura e escrita. Na primeira fala, a professora também considera o sujeito que escreve e aponta a escrita como uma criação a partir da elaboração da língua, falando em "escrita própria" ou com as "palavras deles".

Em relação a esta fala, cabe uma reflexão sobre a forma como costumamos lidar com a escrita na escola. Como professora e pesquisadora, muitas vezes observamos a recomendação de que os estudantes deveriam "escrever com as próprias palavras". Normalmente isso se fala na escola com o sentido de autoria ${ }^{32}$, quando buscamos que nossos alunos desenvolvam outras formas de textos, que não sejam apenas repetições empíricas, na qual o estudante apenas diz o mesmo, como um exercício de memória puro e simples. Achamos que assim estamos evitando o "efeito papagaio". Mas, mesmo que os estudantes façam repetições formais ou históricas, com autoria, dando um sentido próprio, não o farão com as palavras do mundo? Com palavras que vêm das interações sociais e históricas que vivenciam? Serão palavras próprias? Por outro lado, será que as palavras do mundo não se tornam deles quando as usam para escrever? Não viram palavras próprias nas escolhas que fazem ao escrever? Como será que os estudantes compreendem essa fala de que devem escrever com as próprias palavras? Tais reflexões em uma perspectiva bakhtiniana são importantes na consideração de como palavras alheias se tornam palavras próprias nos processos de ensino-aprendizagem e são

\footnotetext{
${ }^{32} \mathrm{O}$ tema do autor e da autoria é bastante relevante e complexo na perspectiva bakhtiniana. Aqui, apropriamo-nos do tema da autoria para trazer o questionamento de como formar um estudante autor. O que significaria formar um autor? Não só do ponto de vista literário, mas também em outros tipos de discurso, como o científico? Para isso, como discutimos nas referenciais, trabalhamos com a ideia de autoria relacionada à expressão do estilo individual do autor na apropriação dos gêneros discursivos. Em uma perspectiva relativa, textos mais autorais seriam aqueles nos quais o estilo individual do enunciatário apareceria mais.
} 
ressignificadas pelos estudantes. Essa ressignificação aparece, por exemplo, nas diferentes formas de redigir um texto, que tem impacto no sentido final daquilo que é escrito. Nesse processo escrevem eles com suas próprias palavras?

Por fim, na consideração das concepções de leitura e escrita das professoras, há o trecho de fala a seguir, no qual a professora faz uma reflexão em relação à escrita de um aluno que consegue escrever a partir do conteúdo das aulas práticas com experimentos, mas não quando o conteúdo é trabalhado em aulas teóricas.

\begin{abstract}
A escrita é problemática porque eles escrevem mal. Mas quando eles entendem o assunto eu consigo ler. Por pior que seja a estrutura da formação das frases deles, as palavras... quando eles compreendem, eles botam ali o assunto. (...) E aí na prova você via que ele tem o conteúdo das aulas práticas. Ele vai lá e consegue, ele escreve. Não escreve assim direitinho, ele não escreve nada direito. Ele bota tudo errado, sem todas as palavras, não forma frases, mas você compreende o que ele quis dizer. (...) Ele interage com a aula prática, não interage com o conteúdo teórico. (Fala de uma das professoras investigadas).
\end{abstract}

Segundo a professora, o aluno consegue de alguma forma escrever quando parte das interações que vivenciou nas aulas práticas com experimentos. Nessa fala, parece-nos que a escrita é concebida com foco na interação. Interação do aluno com a prática e com o próprio texto. Para escrever dependemos da interação com o que vivenciamos, com o texto que construímos e com o leitor dos nossos textos. É a interação social que nos permitirá produzir linguagem (escrita).

Em síntese, o estudo das entrevistas mostrou concepções distintas que se misturam nas falas das professoras. $\mathrm{O}$ aparecimento de entendimentos que incluem os sujeitos e as interações que vivenciam no entendimento sobre o que seja leitura e escrita possibilita que surjam processos diferenciados de ensino-aprendizagem destas atividades nas aulas de Ciências. Afinal, se há mudanças em relação às reflexões sobre o que significa construir um texto ou compreender um texto, é possível pensar em outras formas de ensinar e aprender a ler e escrever. Silva (1999) discute as relações entre as concepções de leitura de professores e as práticas escolares e coloca que:

concepções parciais do processo de leitura podem levar a resultados altamente nefastos para a educação escolarizada dos leitores (...) porque estarão praticando a leitura, ao longo do seu período de formação, a partir de paradigmas teóricos simplistas, que não levam em conta as múltiplas facetas e a essência do ato de ler (SILVA, 1999, pg. 14 e 15). 
Em seu trabalho, o autor organiza diferentes concepções docentes sobre leitura que categorizou a partir de seus mais de vinte e cinco anos de pesquisa na área, especialmente com professores do ensino fundamental. $\mathrm{O}$ autor descreve visões sobre leitura que denomina de redutoras e sintetiza nas ideias "Ler é traduzir a escrita em fala", "Ler é decodificar mensagens", "Ler é dar respostas a sinais gráficos", "Ler é extrair a ideia central”, "Ler é seguir os passos da lição do livro didático", "Ler é apreciar os clássicos". Andrade e Martins (2006) também pesquisaram sentidos atribuídos à leitura por professores, mais especificamente, professores de Biologia, Física e Química do ensino médio, problematizando a relação entre ensino das ciências e leitura. Em uma perspectiva da análise de discurso francesa, estudaram sentidos, conceitos e concepções de leitura que aparecem em seus discursos. Concluem que os discursos dos professores sobre leitura e formas de ler são marcados por interações e experiências que vivenciaram na família, na escola como alunos, na graduação e na atuação profissional. Parece haver em seus discursos uma relação entre os modos de leitura e os tipos de textos, na qual os textos científicos teriam sentido único e o modo de lê-lo seria para buscar e assimilar informações. Destacam ainda a ausência de reflexões na formação inicial e continuada dos professores sobre o papel da leitura na aprendizagem de Ciências, levando a uma visão reducionista sobre linguagem e leitura. Na investigação realizada, percebemos que há concepções das professoras que se aproximam das ideias destacadas nos estudos de Silva (1999) e de Andrade e Martins (2006), mas, junto a estas, notamos que também aparecem outros sentidos sobre leitura e sobre escrita que são mais complexos, visto que consideram os sujeitos leitores e autores e as interações que vivenciam.

As variadas concepções que apareceram nas entrevistas podem ser associadas a diferentes práticas pedagógicas envolvendo leitura e/ou escrita que observamos nas aulas. As práticas de leitura em alguns momentos envolveram a centralização desta atividade e determinação de um sentido único pela professora, e em outros aconteceu uma leitura mais aberta, que envolvia muitos diálogos e interações com o texto. Em relação às atividades envolvendo escrita, em alguns momentos se limitaram a cópias do quadro e em outros à produção de textos com mais autoria. Apresentamos trechos retirados de aulas observadas que exemplificam as variações de práticas de leitura e de escrita nas aulas. No primeiro exemplo, a atividade realizada pelos alunos era copiar um texto escrito no quadro 
pela professora e perguntas sobre ele, para serem respondidas posteriormente (em casa).

"A professora coloca no quadro um pequeno texto e manda os alunos copiarem em seus cadernos. Ela tira o texto do seu próprio caderno. Depois do texto, escreve algumas perguntas.

Texto: Cadeia alimentar

São as relações alimentares estabelecidas entre os seres vivos.

Os seres vivos que iniciam as cadeias alimentares são chamados de produtores. São as plantas e algas, capazes de produzir alimento por meio da fotossíntese.

Os seres vivos que consomem outros seres vivos são chamados de consumidores. Os que se alimentam dos produtores são chamados de consumidores primários; os que se alimentam dos consumidores primários, são chamados de consumidores secundários e os que se alimentam destes são os consumidores terciários.

Os consumidores podem ser herbívoros, quando se alimentam apenas dos produtores (plantas e algas); carnívoros quando se alimentam só de outros animais, ou onívoros, quando se alimentam tanto de plantas quanto de animais.

Exercícios:

1) A cadeia alimentar pode começar com um animal? Explique.

2) Quem são os seres chamados de produtores?

3) Qual o nome do processo no qual os produtores fazem o alimento?

4) Milho $\rightarrow$ galinha $\rightarrow$ cobra $\rightarrow$ gavião

a) Qual o produtor?

b) Qual o consumidor primário?

c) Qual o consumidor secundário?

d) Qual o consumidor terciário?

e) De onde vem a energia usada pelos produtores?

5) Classifique o ser vivo como herbívoro, carnívoro ou onívoro.

a) zebra

b) ser humano

c) porco

d) leão

- Alunos copiam. Alguns perguntam: O que tá escrito ali? Os exercícios são para fazer em casa." (Notas do diário de campo e transcrição de audiogravação).

A atividade de escrita realizada se limitou à cópia de um texto do quadro. Mesmo que depois do texto tenham aparecido exercícios, inclusive uma pergunta que traz o termo "explique" ao final que permite uma resposta com mais espaço para desenvolvimento da escrita, no momento transcrito a atividade consistiu apenas em copiar o texto e depois os exercícios. Nesse momento, escrever era 
apenas copiar um código. Cassiani-Souza e Almeida (2005) colocam que é comum observarmos nas aulas de Ciências estudantes escrevendo o que o professor dita ou copiando o que ele coloca no quadro, sendo importante o desenvolvimento de novas condições de produção escrita nesses espaços-tempos escolares. Nesse tipo de atividade que observamos, a cópia era a produção escrita realizada.

No trecho a seguir, a atividade de escrita proposta incluiu outros aspectos, não somente a cópia de um código. Era uma questão de uma prova elaborada pela professora, que demandava uma produção textual.

\begin{abstract}
"A professora entrega as provas para os alunos presentes. Um aluno comemora o resultado. A professora começa a corrigir a prova. A Professora lê a questão 1 da prova. Explica a questão, conversando com uma aluna. Depois da discussão escreve a resposta no quadro. Diz que quase toda a turma acertou essa resposta:

Professora: Sobre o experimento. Vamos ver se vocês concordam ou não. Professora lê: No experimento feito no laboratório, colocamos um copo com algodão em seu fundo e uma vasilha cheia de água como está na imagem abaixo. Quando levantamos o copo vimos que o algodão saía seco. Explique por que o algodão saiu seco nessa situação". (Notas do diário de campo e transcrição de audiogravação).
\end{abstract}

Percebemos que a atividade de escrita da prova era sobre um experimento que tinham feito em aula. Assim, a produção do texto dependia da interação com algo que vivenciaram. Além disso, o enunciado solicitava que explicassem o resultado observado, o que permite maior autoria de escrita, visto que estimula que apareça mais o estilo do autor, diferente do que aconteceria em uma questão que fosse simplesmente citar um termo ou um conceito. Como estilo do autor, me refiro, em uma perspectiva bakhtiniana, à forma como o conteúdo escrito é organizado. Nesse sentido, explicar algo permite que o autor exponha o conteúdo de diferentes formas escritas e inclusive use diferentes conteúdos na explicação, aparecendo mais sua autoria. Dessa forma, parece-nos que essa atividade de escrita é mais complexa que a primeira apresentada, que incluía apenas a cópia de um texto.

$\mathrm{O}$ trecho abaixo se refere a outra atividade de escrita que a professora descreveu na entrevista.

Eles fazem até textos. Às vezes eu peço, quando a gente acaba o bimestre e tal, eu peço para eles contarem um pouco. Pedi, por exemplo, da água. Fala o que você aprendeu sobre a água. Aí eles escrevem um texto... (Fala de uma das professoras investigadas) 
Defendemos que essa atividade estimula mais a produção autoral que o exemplo anterior, visto que a proposta desenvolvida potencializa que os estudantes expressem mais livremente aspectos que os marcaram nas aulas de Ciências, sem se restringirem a uma questão específica. De acordo com Bakhtin, todo enunciado é individual e por isso pode refletir a individualidade de quem fala ou escreve. No entanto, alguns gêneros do discurso são mais propícios ao reflexo da individualidade que outros, ou seja, permitem que apareça mais o estilo individual de quem fala ou escreve (BAKHTIN, 2016), o que acontece nesse caso, devido à forma como a atividade foi solicitada, mais pessoal e aberta.

O quarto exemplo que apresentamos traz a transcrição de um momento da aula no qual a professora estava lendo em voz alta para a turma textos do Caderno Pedagógico de Ciências sobre o ecossistema restinga (COORDENADORIA DE EDUCAÇÃO DO RIO DE JANEIRO, 2016 b, pg.11).

\begin{abstract}
"Na página 11, a professora vai lendo os textos e comentando. Ela lê sem intervenção dos alunos.

Professora: Na página onze, tem um outro ecossistema, chamado de restinga. Lê: A restinga é um ambiente característico da mata atlântica, é o bioma que a gente tem aqui no Rio de Janeiro, e todo o litoral do nosso país. (...) Para as aves o ambiente é bastante favorável, sem falar dos insetos que encontram na restinga o ambiente adequado para o seu desenvolvimento, principalmente em relação a borboletas e lavadeiras. No sentindo mais amplo, o termo restinga é usado para indicar o ecossistema que fica logo após o oceano, próximo às praias.
\end{abstract}

Professora: A Lavadeira pega água, por isso tem o nome de lavadeira

Estudante A: Ela voa?

Professora: Voa. Aí a gente tem imagens do Parque Chico Mendes. A água, a areia, e os animais, o pássaro tiê-sangue, esse nome é pela coloração bem vermelha dele. E outro que é o jacaré.

Professora: Então o tiê-sangue, que é essa avezinha aí, a gente falou dela lá no começo quando falou da praia de Grumari. Lê: O Parque Chico Mendes possui cerca de cento e vinte tipos de aves já observadas, galinhas d'água, frango d'água, jaçanã ou cafezinho, tiê-sangue, (comenta: o da foto), rolinha da restinga, além de uma outra infinidade de passarinhos que podem ser vistos ou ouvidos em uma visita ao parque.

Professora: O jacaré de papo amarelo faz parte da fauna desse parque. Lê: a planície de Jacarepaguá é um local onde ainda sobrevive o jacaré. (...).

Professora: E a Flora do parque? Em cima do desenho do jacaré está mostrando aí a figueira vermelha, que é uma espécie da mata atlântica que é encontrada nesse parque Chico Mendes. Lê: E serve de alimento para preguiças, morcegos e aves diversas. É uma árvore frondosa (comenta: com esses galhos aí com bastante folhas) com raízes adaptadas que se fixam no solo arenoso". (Notas do diário de campo e transcrição de audiogravação).

Percebemos que a professora centralizou as leituras e os sentidos que 
podiam ser produzidos, sem discutir os textos e sem trazer as vozes dos alunos. Foi uma atividade bastante monológica, que neutralizou outras vozes, instaurando uma só voz dominante, tanto na interação entre a professora e os estudantes, quanto na própria arquitetura composicional dos textos.

O quinto e último exemplo, se trata também de uma atividade pedagógica envolvendo leitura, mais especificamente, a leitura de uma imagem do Caderno Pedagógico (COORDENADORIA DE EDUCAÇÃO DO RIO DE JANEIRO, 2016 a, pg. 22).

"Professora pede que os alunos peguem a apostila e começa a comentar a página 22. Dialoga com os alunos.

Professora: O que é essa imagem da página 22? Quem já viu isso?

Estudantes: Catavento!

Professora: Mais ou menos. O catavento é para brincar. Esse é para brincar?

- A Professora conversa sobre fontes de energia. Fala da energia do vento. Das hélices.

Professora: Qual outra fonte de energia sem ser essa aí, chamada de energia...

Estudante A: Eólica.

Professora: Eólica

- A professora escreve ENERGIA EÓLICA no quadro. (...)

- A professora discute com os alunos sobre impactos relacionados à energia eólica. Relaciona com a imagem que estavam vendo.

Professora: E aí, eu pergunto para vocês. Vocês acham, olhando para essa imagem aí, que construir esse tipo de equipamento para conseguir energia eólica vai causar algum impacto no meio ambiente? Ou não. Não tem problema não, é uma energia que a gente chama de energia limpa porque não perturba o ambiente?

Estudante D: Acho que não tem problema.

Professora: Você acha que não tem problema nenhum construir isso aí? E por que?

Estudante D: Por que não solta nada no ambiente.

Professora: Porque você não está jogando nenhuma substância no ambiente. É isso?

Professora: E você K.? O que você acha? Você acha que é uma energia que não causa nenhum impacto no ambiente ou pode causar algum impacto?

Estudante E: Mais ou menos.

Professora: Mais ou menos? Gente, olha só essa imagem. Vocês acham que o espaço usado para construir isso daí é pequeno ou é enorme? T. que teve aí presencialmente. Vendo essa imagem aí e lembrando quando você olhou, foi no Nordeste mesmo? Era uma área pequena ou era uma área enorme?

Estudante F.: Enorme.

Professora: Enorme. Olha só. Só pela imagem dá para ver. Olha quantos tem aí. Então vocês acham que para construir essa estação aí, você teve que 
devastar uma grande área? Uma grande... Sei lá. Um lugar que tenha floresta ou um lugar que tenha algum tipo de vegetação?

Estudantes: Sim.

Professora: Sim. Então esse tipo de energia, assim como a energia hidrelétrica, aquela que a gente estudou, as pessoas costumam achar que não tem nenhum tipo de impacto porque é uma energia considerada limpa, só que a gente tem sim impactos no ambiente para construção desse tipo de obtenção de energia aí. Lógico que é uma energia que vai ter um impacto menor do que, por exemplo, uma usina nuclear. Se vazar, acabou, né? É uma coisa muito mais grave. Agora, tem um impacto? Tem. Só que ele não é tão grande quanto de outras formas de obtenção de energia". (Notas do diário de campo e transcrição de audiogravação).

Percebemos que nesse caso a professora realizou a leitura trazendo as vozes dos alunos, discutindo com eles e os estimulando para que criassem sentido para a imagem que liam. Vemos que ela inclusive trouxe a voz de uma aluna que mencionou ter visto um lugar semelhante ao que aparecia na fotografia. Aqui a atividade funcionou a partir de um entendimento mais próxima da ideia de leitura como um processo interativo e dialógico.

\subsection{2. \\ Dificuldades nos processos de ensino-aprendizagem de leitura e escrita}

As professoras, ao discutirem atividades pedagógicas que envolvem leitura e/ou escrita, destacaram dificuldades que sentem ao realizá-las. Refletir sobre essas dificuldades é importante, pois podem estar associadas às possibilidades de leitura e escrita que constroem em suas aulas e às concepções sobre o significado desses processos.

A primeira dificuldade que mencionaram se refere a lacunas na formação docente em relação a processos de ensino-aprendizagem de leitura e escrita.

1) (...). Porque a gente, assim eu sou professora de Ciências e Biologia, eu não tenho muita base teórica, fundamentação para poder falar disso. (Fala de uma das professoras investigadas).

2) Mas eles não chegam num nível assim tão absurdo, de não conseguir escrever, ler nada... Eu não lembro e se eu pegasse, sinceramente, não sei o que eu ia fazer não. Talvez conversar com o pessoal de língua portuguesa, que talvez tenha algum conhecimento sobre isso. (...) Porque além de eu não ter base, não ter formação para alfabetização, eu tenho que dar conta de tantos alunos. (Fala de uma das professoras investigadas).

3) Mas eu não sei como é trabalhado isso. Eu não sei qual a intensidade, quantas aulas eles têm... Não sei. (...) Então é um vazio. É como se tivesse 
um vazio. É um vazio e aí eu tento sentir e sozinha descobrir formas de ajuda-los. Mas eu sei que as minhas formas não são as melhores também. Eu tento. (Fala de uma das professoras investigadas).

4) Aí eu converso com o professor de Português. Eu falo: olha ele não escreve legal e tudo mais. Porque é o professor de português que consegue avaliar melhor. O aluno escreve redação, faz mais textos de interpretação e tudo mais, então ele consegue avaliar melhor. (Fala de uma das professoras investigadas).

5) E isso traz uma dificuldade para eles, uma dificuldade para mim que não sei trabalhar com essa falta de interpretação, com essa falta de leitura. (...) E tento às vezes trabalhar com professores de Português para, identificando os alunos que têm essa dificuldade de interpretação, para que eles deem essa ajuda, porque eu não sei, eu não consigo... (Fala de uma das professoras investigadas).

6) E sempre converso com o professor de Português para ver se ele dá conta ou se consegue ajudar, porque eu acho que ele tem mais base do que eu para fazer um trabalho específico. (Fala de uma das professoras investigadas).

Destacamos que as professoras sentem que não tem base teórica para reflexão sobre os processos de leitura e escrita. Colocam que não são formadas para lidar com dificuldades mais específicas, com as quais os estudantes se defrontam ao ler, como dificuldade de interpretação. Sem formação para lidar com esses obstáculos, dizem que procuram a ajuda de docentes de outras disciplinas, especialmente de Português. Estabelecer parcerias na escola, buscando projetos comuns parece-nos adequado, afinal diferentes professores podem contribuir para a formação de alunos leitores e escritores, especialmente, se atuarem em conjunto. Nesse sentido, a fala de que buscam outros docentes da escola, mostra o comprometimento das professoras com a aprendizagem dos seus alunos. Porém, o fato de não se sentirem preparadas para lidar com essas questões mostra uma importante lacuna na formação, que aparece como o "vazio" mencionado pela professora. Considerando que em todas as aulas de Ciências observadas houve atividades pedagógicas com leitura e escrita de textos, não seria importante que a formação destas professoras incluísse reflexões sobre esses processos? Andrade e Martins (2006), em sua pesquisa com análise de discurso de professores de Ciências sobre leitura, revelaram que, para o grupo de professores investigado, não existiu na sua formação inicial e nem ao longo da atuação profissional espaços de reflexão sobre o papel da leitura no ensino e na aprendizagem de Ciências. Como notei também nas entrevistas das professoras que participaram da presente pesquisa. 
Além da questão da formação, as professoras falaram muito nas entrevistas sobre questões estruturais que dificultam o trabalho com leitura e escrita nas salas de aula de Ciências, como vemos nos trechos a seguir:

1) (...) Então assim, eles não tem acesso a esses livros. Pelo menos nesse ano não tiveram. (Fala de uma das professoras investigadas).

2) Então eles começaram a ter uma apostila e ter uma prova de ciências, que antigamente não tinha. Só que isso é ruim porque para de receber os livros e as apostilas são muito básicas. Acho que falta muita informação. (Fala de uma das professoras investigadas).

3) (...). Eu tive uma dificuldade porque eu só tinha quinze livros para as três turmas de sexto ano que eu tenho. (Fala de uma das professoras investigadas).

4) Porque o material didático que a gente recebe é limitado porque não tem livro, a apostila é ruim e eu quero construir meu próprio material didático, mas eu também tenho a limitação da quantidade de xerox. (Fala de uma das professoras investigadas).

5) Eu não trago textos para eles especialmente por conta de xerox. A gente tem cotas reduzidas de xerox. Então tudo que a gente faz é muito falado e eu tento passar vídeo quando as coisas funcionam. (Fala de uma das professoras investigadas).

6) Tem aquela sugestão de trabalhar com dicionário, não sei o que... Só que como? Onde tem dicionário na escola? (Fala de uma das professoras investigadas).

7) Uma coisa que eu percebo que eles não têm é um espaço para eles estudarem, para eles fazerem um trabalho de grupo. (...). Porque eu fico pensando, se eles não têm um canto na casa deles onde eles possam estudar, se concentrar e ler qualquer coisa que seja, como é que eles vão conseguir numa sala de aula isso? (...) a sala de leitura acontecendo, eu conseguindo fazer isso, primeira coisa que eu quero tentar fazer é ter um espaço para eles ficarem em silêncio para se concentrar e ler, estudar sabe. Eles não sabem ler, eles não sabem como estudar (...) (Fala de uma das professoras investigadas).

Nestas falas, a falta de recursos materiais aparece como obstáculo para processos de ensino-aprendizagem de leitura e escrita nas aulas de Ciências. As professoras mencionaram a falta de livros didáticos e dicionários e indicaram a impossibilidade de levarem cópias de textos variados. Ainda em relação aos recursos materiais, uma das professoras ressaltou o problema da falta de um espaço para leitura na escola, visto que a biblioteca e a sala de leitura estavam fechadas na escola que ela trabalhava. A falta de livros e de cópias restringe o acesso à diversidade de textos pelos estudantes, de forma que o trabalho com textos fica restrito àqueles dos Cadernos Pedagógicos. Formar um leitor e autor exige o acesso a textos diversos e a produção de espaços e tempos para leitura e para a escrita. A 
ampliação do repertório de leitura é central para ensino-aprendizagem da leitura e da escrita, como têm demonstrado diferentes pesquisas em educação (por exemplo, Koch e Elias, 2015).

A questão estrutural colocada pelas professoras se refere também à maneira como o sistema de educação da rede municipal do Rio de Janeiro tem sido organizado, como mostram as seguintes falas:

1) Eu tento ajudar como posso. Às vezes não é possível porque as turmas são muito cheias, muito barulhentas e... você dá atenção para um, cai o mundo no resto da turma. (Fala de uma das professoras investigadas).

2) (...) a gente esperava que eles já viessem bem alfabetizados. Infelizmente não vem. Essa eu acho que é a maior dificuldade, não é isso? (Fala de uma das professoras investigadas).

3) (...) nas dificuldades do aluno em fazer questões discursivas, em formular respostas... e eu acho que isso tem, esteja relacionado com a cultura da escola e do município no geral. Começando que o aluno aqui tem três anos para ser alfabetizado (...). E aí tem essas questões da aprovação. Para você reter um aluno no município é muito complicado. As turmas são cheias, é difícil o professor dar uma atenção especial... A gente não tem um reforço para os alunos que tem dificuldade, que estão mais atrasados em relação a outros alunos. Então acho que tudo isso contribui para que o aluno chegue no sexto ano com uma certa defasagem, dificuldade na leitura e na escrita. (Fala de uma das professoras investigadas).

4) Mas a cultura que o município tem é que o aluno não trabalhe muito a escrita. Então a gente tem essa dificuldade. Por exemplo, a apostila deles. A apostila ela dificilmente tem questões discursivas, que o aluno tenha que construir uma resposta. (Fala de uma das professoras investigadas).

5) Tenho vontade de fazer doutorado sim, mas o município me limita nessa questão. Por causa do horário a gente não tem nenhum um tipo de negociação. (Fala de uma das professoras investigadas).

Nestas falas, as principais dificuldades citadas se referem ao grande número de alunos por turma, ao sistema de aprovação/reprovação dos alunos, à falta de um projeto político e pedagógico de formação para a escrita e ao pouco investimento na formação continuada dos professores.

Em relação aos processos de ensino-aprendizagem de leitura e/ou escrita, o grande número de alunos nas turmas impede a realização de um trabalho mais individualizado, muito importante considerando que o desenvolvimento do potencial dos estudantes de leitura e de escrita é muito heterogêneo. Se aprendemos na interação com os outros, é fundamental que os alunos interajam entre si e que a professora tenha possibilidade de interagir com cada um dos seus estudantes através de enunciados escritos, para que os estudantes desenvolvam suas condições de 
leitura e de escrita. A professora colocou que a aprovação e/ou retenção dos alunos pode influenciar no potencial de leitura ou escrita. Isso parece fazer sentido, porém ainda é preciso pesquisar e entender melhor a maneira como a trajetória escolar dos alunos influencia na sua história de leitura e escrita e na formação para esses processos. Ainda em relação estas falas, uma das professoras enaltece a vontade de ampliar sua formação, com o curso de doutorado, já que na época da entrevista tinha terminado o mestrado há pouco tempo. Mas, a impossibilidade de ter licença para esse fim mostra a necessidade da reflexão sobre como tem sido o investimento na formação continuada de professores da rede municipal do Rio de Janeiro.

Outra questão trazida pelas professoras diz respeito ao controle do trabalho realizado, que se reflete no uso da maior parte do tempo das aulas para abordar conteúdos determinados pelo Caderno Pedagógico e associados a avaliações externas. Isso dificulta que trabalhem outros textos e abordem outras questões de ensino-aprendizagem, como a formação para leitura e escrita.

1) Mas eu acho que seria interessante trazer mais textos. Eu gostaria de trazer mais textos, mais curiosidades (...). Mas onde na aula que eu consigo encaixar? Porque são poucos tempos de aula. A gente tem que trabalhar aquela apostila porque é o que cai na prova e é o que depois... sei lá.. vai medir lá os índices se a escola melhorou ou não. Aí fica faltando um tempo ali pra trabalhar esse tipo de coisas. Falta muito isso. (Fala de uma das professoras investigadas).

2) Uma coisa que eles poderiam treinar a leitura, que eles... A gente poderia propor experimentos baseados no que eles viram, pesquisar coisas na internet... A gente tem uma sala de computadores ali que a princípio funciona e é bem legal. Mas eu nunca consegui levá-los. (...) Pelo tempo. (Fala de uma das professoras investigadas).

3) Não dá para fazer sempre porque você tá muito amarrado com a questão do conteúdo. (...) Por mais que você queira fazer coisas diferentes, você tem que estar sempre pensando coisas diferentes que possam te ajudar no conteúdo que você tem que dar conta naquela hora ali no município. Isso te aprisiona muito. (...) e tem a questão da prova da prefeitura que você tenta fugir, mas é uma pressão absurda em cima da direção que pressiona os professores... e você fica muito amarrado. Tem professor aqui na escola que nem considera a prova da prefeitura. Eles fazem por fazer (...) Apesar de eu ser total a favor de fazer isso para quebrar com essa camisa de força da prefeitura, eu também estou numa sala de aula. (...). Para eles prova tem um sentido, tem um significado. Aí eu vou chegar pra eles e falar, olha só é uma prova, mas não vai valer nada. Eu acho que na cabeça deles também fica muito confuso porque eles não têm essa dimensão do porque eu estou fazendo isso. (...) e aí fico sem saber como burlar. (Fala de uma das professoras investigadas).

4) E aí quando eu consigo fazer uma coisa diferente, que eu já fiz por meio de texto, de vídeo eu também já fiz... que é uma forma também que eu tento escapar um pouco. Eu vou tentando encontrar momentos que eu possa escapar (Fala de uma das professoras investigadas). 
Luz (2016) desenvolveu sua pesquisa de mestrado sobre o uso dos Cadernos Pedagógicos no ensino de Ciências em turmas do ensino fundamental da Secretaria Municipal de Educação do Rio de Janeiro. Em sua pesquisa, a autora associa a implantação dos Cadernos Pedagógicos à política de reformulação curricular ${ }^{33} \mathrm{da}$ educação da rede municipal do Rio de Janeiro, inserida em um contexto global de reformas educativas que vêm acontecendo desde a década de 1990, com o aprofundamento do capitalismo neoliberal. Nessas novas políticas, a educação é enquadrada em uma lógica mercadológica e os processos pedagógicos se reduzem a processos de produção e de fornecimento relacionados a objetivos do mercado, tais como mecanismos de transferência eficiente e métodos externos de controle. As escolas passam a sofrer imposições pelo cumprimento de metas e busca de resultados quantificáveis.

$\mathrm{Na}$ Secretaria de Educação do Rio de Janeiro, as novas políticas educacionais foram aplicadas na forma de orientações curriculares mínimas e descritores que guiam a elaboração de Cadernos Pedagógicos, associados a avaliações externas bimestrais, que integram índices para as escolas e bonificação salarial docente associada a esses índices. Essa nova lógica transforma o trabalho e o cotidiano das escolas, ressignificando o trabalho docente, que se torna cada vez menos autônomo. Segundo Luz (2016), a implantação da política educacional associada ao uso de Cadernos Pedagógicos e provas externas bimestrais trouxe uma insatisfação enorme para professores da rede municipal. $\mathrm{O}$ que a pesquisadora coloca que foi percebido, por exemplo, nas rodas de conversas entre docentes, nos Conselhos de Classe e nas reuniões de planejamento nas escolas, nas redes sociais, e especialmente na greve de 2013, na qual aproximadamente $90 \%$ da categoria docente do município parou por três meses, sendo uma das pautas principais, a falta de autonomia de trabalho. Essa insatisfação com a perda de controle do próprio trabalho apareceu também na fala das professoras que investigamos, que constroem formas de resistência, o que notamos, por exemplo, quando a professora diz que tenta "burlar" o sistema e que "busca momentos que possa escapar".

Por fim, as professoras destacaram dentre os obstáculos para o trabalho com leitura e escrita questões relacionadas ao contexto econômico e social de vida dos

\footnotetext{
${ }^{33}$ Resolução SME n ${ }^{\circ}$ 1010, de 04/03/2009.
} 
alunos, mais especificamente mencionaram a falta de estrutura familiar e o entorno de muita violência, que afeta o cotidiano escolar. Estudos no campo da sociologia da educação têm mostrado que o contexto social dos alunos tem forte correlação com o desempenho escolar (por exemplo, Bonamino et al, 2010).

1) Eu acho que também tem uma coisa anterior. Minha mãe, na época ela não trabalhava, ela tinha esse tempo disponível, ela estudava com a gente. Eu aprendi a estudar com a minha mãe. (...). Eu tinha alguém pra estudar comigo. (...) Então é muito difícil você ter que suprir isso tudo em cinquenta minutos de aula (...) Muito difícil. Muitos alunos não têm esse suporte em casa. Às vezes é uma casa que tem um cômodo com várias pessoas, muitas crianças (Fala de uma das professoras investigadas).

2) A gente estava com muitas atividades e aí essas confusões de fechamento da escola já tinham acontecido anteriormente. Eu não estava conseguindo trabalhar exatamente como eu gosto com eles. (Fala de uma das professoras investigadas).

Além de mencionarem as dificuldades que percebem para realização do trabalho, as professoras colocaram também como veem as dificuldades de leitura e/ou escrita dos alunos.

1) (...) os alunos não conseguem responder questões das minhas provas porque eles não entendem o que está sendo perguntado. (...) Não compreendem perguntas do tipo me dê um exemplo. A maioria dos alunos não sabe o que é dar um exemplo. (Fala de uma das professoras investigadas).

2) (...) principalmente de interpretação... construir respostas, eles têm essa dificuldade, se expressar de forma escrita e principalmente de acentuação e pontuação. (Fala de uma das professoras investigadas).

3) Então também tem aquela coisa automática. Eu estou juntando as palavras, falando, mas...eu não estou fazendo sentido com aquilo. Eles parecem que não incorporam o texto... (Fala de uma das professoras investigadas).

4) Eu já tive aluno que não escrevia e não lia absolutamente nada, que escrevia só o próprio nome, o primeiro nome, nem o nome todo ele sabia escrever. (Fala de uma das professoras investigadas).

5) (...) porque os meus alunos simplesmente não liam. Eles não liam as questões. Eles, além de reclamar, eles não liam e tinham também muita dificuldade em escrever, em formular questões discursivas. Então eles deixavam em branco, eles nem tentavam escrever. (Fala de uma das professoras investigadas).

6) Então eles ficam também muito aflitos. Eu já tive alunos de outras turmas que ficam aflitos porque eu não fico colocando resposta no quadro. Mas você não colocou. (...) Eles estão muito acostumados a está no quadro, copia, passa pro papel. (Fala de uma das professoras investigadas).

7) No sexto ano tem menos nomes para eles decorarem, isso facilita. É mais conceitos. Alguns conceitos bem abstratos. É aí que está a dificuldade, não 
na leitura e na escrita em si. Na abstração, é, conceito de molécula, de pressão... (Fala de uma das professoras investigadas).

8) Eu acho que dificuldades específicas das ciências são as nomenclaturas que eles não tão habituados. Palavras que eles não costumam usar no dia a dia. Então eles têm essa dificuldade, tanto de lembrar a palavra, quanto da escrita da palavra. (Fala de uma das professoras investigadas).

As professoras relatam dificuldades referentes ao entendimento dos textos (construção de sentidos), que incluem enunciados e determinadas palavras ou signos, algumas pertencentes ao campo científico e outras comuns, como "exemplo". Se referem a dificuldades para uso da linguagem escrita, para compreensão e produção de textos próprios, sem apenas copiarem. Uma das professoras menciona inclusive um aluno que considerava analfabeto. Dentre as dificuldades aparecem ainda a abstração e o uso de termos científicos, questões mais específicas do ensino de Ciências. Mortimer et al (1998), ao discutir pesquisas realizadas sobre a linguagem no ensino de Ciências, destaca que estas verificaram que entidades abstratas fazem parte das aulas de Ciências (por exemplo átomos, moléculas, fotossíntese, etc.), e que trazem dificuldades no uso da linguagem pelos alunos, como a professora trouxe em sua fala.

Nas entrevistas, as professoras construíram reflexões sobre como buscam lidar com as dificuldades que aparecem. Com lacunas na formação docente, buscam experiências que vivenciaram em suas histórias de vida como alunas e desenvolvem saberes ao longo da atuação como professoras, quando se defrontam com dificuldades dos estudantes para ler e escrever e ao mesmo tempo aprender Ciências.

1) Eu acho que também isso foi uma coisa que eu, aliás tudo que eu fiz, eu acho que eu fiz no improviso. (...) Porque você não tem base. (...) E eu busco também na experiência. Assim, o que eu faço pra eu poder me concentrar, pra eu fazer uma leitura, pra eu saber se eu estou... Eu acho que eu pego muito também da minha vivência como aluna e vou testando e vendo se vai fluir, se não vai fluir... (Fala de uma das professoras investigadas).

2) (...) eu tiro muito do que eu vivi na escola. Eu não conseguia decorar nada desses termos. Eu só fui entender, só fui... guardar comigo os termos, depois que eu consegui entender o que eles significavam. Então por isso que eu trabalho muito o significado das coisas com eles. (Fala de uma das professoras investigadas). 
Os alunos discutiram também suas próprias dificuldades para ler e para escrever nas aulas de Ciências. Se referiram especialmente à questão do uso de termos específicos do ensino de Ciências, semelhante ao que uma das professoras trouxe em uma de suas falas. Além disso, mencionaram dificuldades que relacionam à velocidade de leitura e escrita:

1) Estudante A: (...) porque tem cada palavra difícil.

Estudante B: Cada palavra tão grande... Cada nome esquisito... (Grupo de alunos de uma das escolas investigadas).

2) Estudante A: (...) Para ler eu sou muito lento.

Estudante A: Escrever as palavras bonitas e escrever rápido. (Grupo de alunos de uma das escolas investigadas).

3) Pesquisadora: Quando vocês leem nas aulas de Ciências, vocês entendem o que está escrito?

Estudante A: Uhum. A maioria das outras coisas (...) Só quando tem aquele nome estranho que a gente não entende.

Estudante B: Tem muita palavra difícil.

Estudante C: Tem algumas coisas que é bem difícil mesmo. (Grupo de alunos de uma das escolas investigadas).

4) Estudante A: Algumas palavras que a gente...Tipo...palavra estranha.

Estudante B: Teve uma vez que eu fiquei... na hora que ela entrou na sala mandando eu fazer a apostila... eu fiquei da hora que ela mandou fazer a apostila até o recreio sem entender um i do que ela falava ali na frente e do que tava escrito ali.

Estudante C: Tinha umas palavras estranhas... (Grupo de alunos de uma das escolas investigadas).

Evidencia-se nas falas dos alunos o estranhamento que experimentam com as palavras mais específicas do ensino de Ciências, que são originárias das ciências de referência e evidenciam tradições curriculares acadêmicas desta disciplina escolar. Esses termos se tornam um obstáculo para a apropriação da linguagem escrita nesse espaço-tempo da escola. O estranhamento nos remete à relação tratada por Bakhtin entre palavras alheias e palavras próprias, mencionada anteriormente. $\mathrm{O}$ autor coloca que nossa experiência discursiva se forma e se desenvolve a partir da interação constante com enunciados alheios e diz que "em certo sentido, essa experiência pode ser caracterizada como processo de assimilação - mais ou menos criador-das palavras do outro (e não das palavras da língua)" (BAKHTIN, 2016, 
pg. 54). Assim, nosso discurso vai se tornando pleno de palavras dos outros e sua expressão, que reelaboramos e ressignificamos, tornando as palavras nossas. Como nas aulas de Ciências os alunos se apropriam das palavras de campos científicos tornando-as próprias? Como se relacionam com a estrutura sintática da linguagem científica? Refletir sobre a linguagem utilizada na ciência é central para o letramento científico dos estudantes e nesse sentido, se torna fundamental para o ensino de Ciências. Aprender a ler e escrever nas aulas de Ciências é também aprender a ler e escrever com gêneros e palavras que se aproximam da linguagem científica, por isso é importante analisar as especificidades dessa linguagem no ensino de Ciências. Santos (2000) comenta em sua tese a importância do ensino de Ciências ultrapassar a ênfase excessiva na terminologia científica, com foco na memorização de termos e nas classificações, e chama atenção para a necessidade da construção de significados para os termos científicos e do entendimento da linguagem como aspecto constitutivo da Ciência. As professoras que participaram da investigação que realizamos colocaram que não focam os processos de ensinoaprendizagem na memorização de termos e buscam sempre construir significados, o que percebemos, por exemplo, na seguinte fala, já mencionada “(...) porque eu não gosto de fazer aquelas perguntas simples, do tipo... qual o nome do processo que a planta faz o seu próprio alimento, para eles dizerem a fotossíntese. Eu gosto que eles procurem interpretar, compreender qual é a importância, porque que faz bem para o meio ambiente a planta fazer fotossíntese... Qual a importância disso na sua vida..." ou nessa outra "eles falam, ah é muito nome, muito nome e realmente é muito nome. Eu costumo não cobrar em prova que eles decorem esses nomes. (...) eu sempre reforço nas aulas que eu não cobro que eles decorem os nomes para as provas. Eu sempre trago os nomes e eles têm que explicar os porquês, tem que saber o que significa aquilo... Às vezes alguns temas limitam. Por exemplo, reino animal”. Nessa última fala, percebemos que a professora destaca que algumas vezes o uso de termos específicos é necessário. Ela reconhece que é preciso significar os termos, não apenas memorizá-los, mas ao mesmo tempo, é necessário trabalhar com eles. Uma das falas de uma das professoras reforça essa questão "Tem essa coisa da minha formação de não valorizar tanto os nomes, mas mais os processos. Mas existem nomes que não tem como você fugir. (...) O nome, as vezes você não tem como fugir". Para os alunos esses termos acabam marcando a relação 
que constroem com a leitura e escrita nas aulas de Ciências de forma negativa, aparecendo como dificuldades.

É importante refletir que o estranhamento dos alunos e a própria dificuldade inicial, podem indicar que percebem que a linguagem científica possui características específicas, o que é fundamental para que pensem sobre formas de escrever e ler nas aulas de Ciências. Sutton (2003) discute que as ciências se constroem também através da linguagem. Assim, para ensinar e aprender Ciências, é preciso refletir sobre a linguagem científica, incluindo os termos específicos. Mortimer et al (1998) também destaca em seu estudo que a linguagem científica possui características particulares que as diferenciam da linguagem comum e que foram se desenvolvendo ao longo do tempo junto com a produção do conhecimento científico. Nesse sentido, defende que "Reconhecer essas diferenças implica em admitir que a aprendizagem da ciência é inseparável da aprendizagem da linguagem cientifica". Para o autor existe um contínuo entre dois extremos que seriam a linguagem comum e a linguagem científica. A linguagem comum é mais linear, sequencial, além de contextualizada, com a presença de um narrador. Já a linguagem científica é mais estruturada, com processos estanques e descontextualizada, com o apagamento dos sujeitos. A linguagem comum seria mais automática e estaria mais próxima da fala cotidiana, enquanto a linguagem científica se aproximaria da escrita. Em diálogo com a teoria bakhtiniana, a linguagem comum se constrói com gêneros primários do discurso, enquanto a científica se desenvolve com gêneros secundários do discurso. Para Mortimer et al (1998), o processo de nominalização da linguagem científica aumenta sua densidade léxica, com a ligação de seus termos próprios em uma determinada estrutura conceitual. De acordo com o autor, as particularidades na forma de construção da linguagem científica e seus termos específicos trazem dificuldades, como verificamos nas falas dos alunos e de uma das professoras que participaram da investigação aqui relatada. Mortimer et al (1998) verificou em sua pesquisa que, nos processos de ensino-aprendizagem, os alunos transitam entre esses extremos, misturando características da linguagem comum e da linguagem científica, como percebeu na análise de respostas de vestibulandos a questões discursivas de Química. Nas observações das atividades com linguagem escrita nas aulas de Ciências, percebemos que as professoras constroem mediações articulando linguagem comum e científica e gêneros primários e secundários do discurso. 
Através dessa articulação, constroem conhecimentos escolares em Ciências e ao mesmo tempo conhecimentos escolares em leitura e escrita de textos, como desenvolvemos mais profundamente na próxima seção.

\title{
4.2. \\ Dialogismo e a linguagem escrita nas aulas de Ciências
}

\begin{abstract}
A existência, porque humana, não pode ser muda, silenciosa, nem tampouco pode nutrir-se de falsas palavras, mas de palavras verdadeiras, com que os homens transformam o mundo. Existir, humanamente, é pronunciar o mundo, é modificá-lo. O mundo pronunciado, por sua vez, se volta problematizado aos sujeitos pronunciantes, a exigir deles novo pronunciar. (FREIRE, 1996, pg. 77)
\end{abstract}

A investigação mostrou que a linguagem escrita é central nas aulas de

Ciências e muitas atividades pedagógicas ocorreram nesse espaço-tempo escolar envolvendo leitura e/ou escrita. Interações sociais entre professoras e estudantes acontecem através da linguagem escrita, que organiza e orienta as aulas. Na seção anterior, construímos reflexões sobre como professoras e estudantes, sujeitos que concretizam essas interações, compreendem a linguagem escrita e suas percepções sobre a vivência dos processos de leitura e de escrita nas aulas de Ciências. Na presente seção, discutimos como as interações sociais se constroem nas aulas através dos textos, ou seja, de que forma os diálogos acontecem com e por entre os textos e que tipo de mediação as professoras realizam entre os estudantes e seus processos de leitura e de escrita.

Defendemos que o fato das professoras estarem todo tempo trabalhando com textos escritos faz com que precisem desenvolver estratégias para que os alunos leiam e escrevam, e assim, acabam se dedicando a processos de ensinoaprendizagem de leitura e escrita em suas aulas. $\mathrm{O}$ trabalho acontece principalmente quando estabelecem diálogos sobre o conteúdo a partir de textos que leem junto com os alunos ou sobre exercícios escritos que os estudantes realizam. Para refletir sobre a construção do conhecimento escolar em Ciências através da linguagem escrita, analisamos três diálogos observados em atividades pedagógicas que envolveram leitura e/ou escrita. O primeiro diálogo aconteceu durante uma 
atividade pedagógica que consistia em perguntas e respostas escritas no caderno. A professora estava corrigindo um exercício que havia passado na aula anterior para ser realizado em casa, no caderno. Tal exercício era composto por quatro perguntas que deviam ser respondidas de forma escrita. A maioria dos estudantes havia feito o exercício. Transcrevemos a seguir o diálogo que se estabeleceu acerca da resposta da terceira pergunta, que se referia a um experimento realizado na aula anterior.

“A professora lê a questão pausadamente: Se acendermos uma vela e colocarmos um vidro sobre ela, o que acontece com a chama da vela? Qual a explicação para isso?

Professora: E aí? O que acontece?

Estudante A: Apaga.

Professora: Por que?

Estudante B: O gás oxigênio acaba.

Professora: Então, a vela apaga, pois o gás oxigênio acaba.

A professora escreve no quadro-negro uma resposta idêntica a sua última fala, formulada junto com os alunos. Alunos escrevem a resposta em seus cadernos". (Notas do diário de campo e transcrição de audiogravação).

O segundo diálogo se estabeleceu a partir da leitura de um texto do Caderno Pedagógico de Ciências do sexto ano de 2016. O texto descreve de forma bastante simplificada alguns experimentos de Joseph Priestley, realizados no século XVIII (COORDENADORIA DE EDUCAÇÃO DO RIO DE JANEIRO, 2016 a, pg. 21). Enquanto lia o texto, a professora interrompia e explicava o que estava sendo lido. $\mathrm{Na}$ explicação, a professora dialogava com os alunos. No trecho transcrito a seguir, a professora havia lido a parte do texto que descreve o procedimento de um dos experimentos e seu resultado e discutia com os alunos hipóteses que explicassem esse resultado.

"Professora: Olha aí o que ele fez depois, no dois. Ele colocou uma plantinha, que é um ramo de hortelã, a vela acesa e fechou o vidro. E, que que ele percebeu?

Estudante A: Que a vela não apagava.

Professora: A vela não apagava. E por que a vela não apaga?

Estudante B: Porque a planta faz fotossíntese.

Professora: A planta quando faz a fotossíntese produz?

Estudante B: Oxigênio.

Estudante C: Tinha luz.

Professora: É, e tinha luz, né? A planta fazia fotossíntese e produzia oxigênio. 
Estudante D: Professora, e se eu me fechar no vidro e colocar uma plantinha?

Professora: Então vamos pensar. Se a gente se fechasse dentro de uma cúpula de vidro fechada a gente morria. Mas e se a gente colocasse uma plantinha junto com a gente?

Estudante E: Aí não.

Estudante D: Mas professora, e se ela for bem pequena?" (Notas do diário de campo e transcrição de audiogravação).

O terceiro diálogo também ocorreu durante a leitura de um texto do Caderno Pedagógico de Ciências do terceiro bimestre de 2016. Este descreve transformações da composição da atmosfera ao longo do tempo (COORDENADORIA DE EDUCAÇÃO DO RIO DE JANEIRO, 2016 a, pg. 19). O diálogo transcrito é mais longo, pois envolve a interação estabelecida antes da leitura em si, durante a leitura e depois da leitura, inclusive a discussão de questões escritas sobre o texto.

"Professora: Na página 19 então.

Professora lê o título da página: A composição do ar sempre foi igual?

Estudantes: Não.

Professora: Qual é a composição do nosso ar mesmo?

Estudante A: Gases

Professora: São gases. E quais são os gases que compõem o planeta?

Estudante B: Oxigênio

Professora: O que tem em maior quantidade?

Estudante A: Nitrogênio.

Professora: Gás nitrogênio

Estudante C: Oxigênio, nitrogênio, carbônico.

Professora: Isso. Os dois principais gases que formam a atmosfera. É o gás nitrogênio, que forma quase toda a atmosfera, né? Depois o gás oxigênio, e aí vem um pouquinho dos menores, pequenininhos em questão de quantidade, gás carbônico, vapor d’água, gás metano... Mas a composição do ar do nosso planeta nem sempre foi a mesma. Já foi muito diferente. Teve uma época que a gente não tinha nem gás oxigênio no nosso planeta.

Estudante D: Foi na época das cavernas.

Professora: Nãããão. Muito antes disso! E para que a gente usa o gás oxigênio?

Estudante B: Pra respirar.

Professora: Pois é. E se a gente não respirar o gás oxigênio?

Estudante D: Vai morrer.

Professora: Isso. Mas e os outros animais?

Estudante D: Vai morrer.

Professora: E as plantas?

Estudante D: Vai morrer. 
(...)

Professora: Nessa época que não tinha gás oxigênio, sabem o que não tinha? As plantas.

Estudante D: Era tudo cinza.

Professora: Por que as plantas fazem o que?

Estudante A: $\mathrm{O}$ ar.

Professora: Fazem o gás oxigênio. Em um processo que a gente chama ...?

Estudantes e Professora: Fotossíntese.

Professora: Então teve uma época no nosso planeta que a gente não tinha gás oxigênio. E sem gás oxigênio também não tinha o que? Os seres vivos. Pelo menos os grandes que a gente conhece, os animais, as plantas... E era uma época também que nosso planeta tinha um monte de erupção de vulcão. Não era que nem hoje que tem duas, três erupções por ano.

Estudante D: E meteoros.

Professora: Caíam muitos meteoros também. E erupções vulcânicas o tempo todo. E o que os vulcões mandam para atmosfera?

Estudante B: Lava!

Professora: Lava. Mas também eles lançam o que?

Estudante C: A fumaça.

Professora: Fumaça. E a fumaça a gente sabe que são? Gases.

Professora: E os gases que o vulcão manda para a atmosfera são diferentes dos gases que os seres vivos produzem. E aí, como tinham muitos vulcões entrando em erupção, era muita fumaça na atmosfera (...). Então vamos ver o texto em verde.

Depois ela mesmo lê o texto da página 19. Ela lê todo texto diretamente. Ao final, faz um comentário. Alunos ouvem com atenção. Mas, parecem prestar mais atenção na professora do que acompanhar a leitura na apostila. Em sua maioria estão olhando para ela e não para a apostila.

Professora lê o texto: Você sabe que nosso planeta já foi muito quente e sem vida. Muito tempo se passou até que seu resfriamento formasse a crosta terrestre. Mas não foi só a crosta terrestre do planeta que se modificou. A sua atmosfera também se transformou ao longo do tempo. Na formação do planeta Terra e da atmosfera, os vulcões tiveram um papel importante. $\mathrm{O}$ lançamento de gases formou a atmosfera primitiva, que era bem diferente da atual. Ela era composta por amônia, vapor de água, gás metano e gás hidrogênio, principalmente. (...) Porém, o planeta Terra e seus ambientes são dinâmicos, isto é, estão sempre ativos, em transformação, podendo ser alterados por atividades naturais ou atividades humanas.

Professora comenta após o texto: Atualmente a gente está vivendo uma modificação na atmosfera por causa dos seres humanos. Lembra que a gente conversou? O que que a gente está lançando um montão para atmosfera?

Estudante A: Gases.

Professora: Quais gases?

Estudante A: Carbônico.

Professora: Carbônico. E aí a gente está tendo uma influência porque, a gente tem mais gás carbônico, e aí tem mais ou menos raios solares na Terra?

Estudante B: Menos 


\section{Estudante A: Mais}

Professora: Mais. E por isso o nosso planeta está esquentando. Quando o vulcão entra em erupção, ele vai também modificar esse equilíbrio, porque ele vai estar lançando mais gases na atmosfera.

Estudante C: E aí?

Professora: Aí pode provocar extinção dos seres vivos, pode causar enchentes em vários locais, secas em outros...

Estudante A: Aqui tá mostrando ó - aponta para a imagem do vulcão na apostila.

Estudante B: Cadê? Quero ver.

Professora: Está mostrando aqui a emissão dos gases...

Professora lê as questões da página 19 e discute a resposta oralmente. Pede para os alunos escreverem o que discutiram. Eles escrevem.

Professora: Aqui tem duas perguntas. Então vamos responder. Número um. Qual foi o papel dos vulcões na atmosfera primitiva?

Estudante A: Formar gases.

Professora: Na verdade ele formou a atmosfera primitiva. Quando ele liberava os gases no interior do planeta, ele estava formando a atmosfera primitiva. Então ele formou a atmosfera primitiva.

Professora: Já dei a resposta. Pode escrever.

Professora dita devagar: Eles formaram a atmosfera primitiva.

Estudante E: Atmosfera o quê?

Professora: Primitiva.

Estudante E: Prêmetiva?

Professora: Primitiva. Bem antiga. Antes dos seres vivos.

Professora espera um pouco para eles escreverem.

P: Anotaram a resposta? Então a segunda. A atmosfera atual tem a mesma composição da atmosfera primitiva?

Estudantes: Não.

Professora: Não. Por que? Hoje em dia a gente tem o que modificando os gases da atmosfera?

Estudante A: Ar?

Estudante B: Árvores.

Estudante C: A chuva.

Estudante A: A gente.

Professora: As árvores, a gente... A gente tem os? Seres vivos. Então ó. A atmosfera atual tem a mesma composição da atmosfera primitiva?

Estudantes: Não.

Professora: Não. Por que? Dois motivos na verdade. A gente tem hoje tantos vulcões em erupção o tempo todo?

Estudantes: Não.

Estudante F: Aqui no Rio não tem vulcão não? No Brasil?

Professora: Não. Não. Não tem vulcão que entra em erupção não.

Estudante F: Não tem vulcão? 
Professora: Só extintos, aqueles que não entram mais em erupção.

Estudante F: E na floresta?

Professora: A floresta não faz parte do Brasil não?

Professora: Então hoje em dia a gente não tem tantos vulcões em erupção e a gente tem o que? Os seres vivos modificando a atmosfera.

Alunos escrevem na própria apostila após a discussão". (Notas do diário de campo e transcrição de audiogravação).

Inúmeros aspectos podem ser analisados a partir dos diálogos transcritos. Inicialmente, destaco aspectos mais gerais, relacionados ao dialogismo das aulas de Ciências. $\mathrm{O}$ estudo da linguagem na materialidade da vida nos permite olhar para o discurso como a língua em ação, em sua integridade concreta e viva, construída nas interações sociais, no momento que o diálogo se estabelece. Nos trechos apresentados, observamos como os diálogos se estabeleceram com os textos. Vemos que nas aulas de Ciências o dialogismo se constituiu entre os discursos dos próprios alunos, entre os discursos dos alunos e da professora e entre estes e o discurso dos textos, ou ainda entre os discursos dos alunos e da professora e discursos de atividades realizadas anteriormente (como o experimento da aula anterior ao trecho 1 descrito).

A análise dos diálogos mostra como nas interações sociais da sala de aula, elementos dialógicos apareceram, em contradição a discursos monologizados que tantas vezes insistem em caracterizar os discursos da escola. Discursos monológicos seriam aqueles que tentam abafar os discursos que permeiam a prática discursiva, como se houvesse ali uma única voz (MARCUZZO, 2008). Embora todo discurso seja por formação dialógico, muitas vezes, esse dialogismo é escondido, e o discurso parece monológico. Tal monologização do discurso restringe a possibilidade de construção de sentidos diferentes, como vemos em alguns momentos nos trechos destacados. No trecho dois, quando a professora lê o texto e explica seu significado, ou no trecho três quando antes mesmo de ler a professora coloca o que espera do texto, ela faz esse tipo de restrição e o discurso tende a se tornar monológico, buscando instituir um sentido único, só a voz da professora, escondendo outras vozes presentes. Nas aulas de Ciências, a monologização costuma ser muito forte, visto que os discursos carregam características da linguagem científica, marcada pela estruturação exata e por processos de nominalização, com a eliminação dos sujeitos e do vivido (MORTIMER et al, 
1998). No entanto, em contradição, as interações sociais com os alunos e com o texto parecem estimular o dialogismo. Vemos que a professora a todo tempo tenta trazer as vozes dos alunos para o diálogo, com seus sentidos para os textos. Os próprios alunos, ao colocarem sua voz nos diálogos, buscam dar um sentido próprio ao que estão processando nos textos, o que podemos perceber nos questionamentos que fazem à professora nos momentos de interação com os textos, como destacamos nos enunciados a seguir:

"Trecho 2 - Estudante D: Mas professora, e se ela for bem pequena?

Trecho 3 - 1) Professora: Teve uma época que a gente não tinha nem gás oxigênio no nosso planeta.

Estudante D: Foi na época das cavernas.

Professora: Nãããão. Muito antes disso!

2) Professora: Nessa época que não tinha gás oxigênio, sabem o que não tinha? As plantas.

Estudante D: Era tudo cinza.

3) Estudante A: Aqui tá mostrando ó - aponta para a imagem do vulcão na apostila.

Estudante B: Cadê? Quero ver.

Professora: Está mostrando aqui emissão dos gases...

4) Estudante F: Aqui no Rio não tem vulcão não? No Brasil?

Professora: Não. Não. Não tem vulcão que entra em erupção não.

Estudante F: Não tem vulcão?

Professora: Só extintos, aqueles que não entram mais em erupção.

Estudante F: E na floresta?

Professora: A floresta não faz parte do Brasil não?” (Transcrições de audiogravação)

Vemos que nos momentos de trabalho com textos, diálogos se estabelecem e os alunos buscam colocar a própria voz nesse diálogo, estimulados pela professora. Assim, a aula de Ciências, como um espaço-tempo de interação social se estabelece como um lugar de relações humanas e, portanto, de linguagem e de diálogos. O diálogo se constrói a partir de enunciações concretas, que dependem do outro para existir. Em uma perspectiva bakhtiniana, todo enunciado é sempre uma resposta a enunciados anteriores e está sempre em busca da atitude responsiva do próximo enunciado. Percebemos isso claramente nos diálogos transcritos. A professora enuncia em busca das respostas dos alunos, que enunciam em busca de uma nova resposta da professora ou de outros alunos, ou de enunciados dos textos. 
Cria-se assim a cadeia discursiva da sala de aula, que vem de outras cadeias discursivas de textos, aulas anteriores e outros espaços sociais. Entendemos que nessas cadeias discursivas processos de ensino-aprendizagem para leitura e escrita se estabelecem.

Nos trechos transcritos, notamos que a professora realiza uma mediação entre os textos lidos ou escritos e os alunos. Compreendendo a leitura e a escrita como processos de interação social entre autor-texto-leitor, percebemos que as professoras atuam na interação que se estabelece entre os alunos leitores e os textos lidos ou entre os alunos autores e os textos produzidos. Nesse processo, acabam por restringir os sentidos possíveis dos textos. Giraldi e Cassiani (2009), baseadas em Orlandi, discutem como na escola a leitura acaba adquirindo sentidos obrigatórios, relacionados à avaliação escolar, que levam ao que chamam de "efeito papagaio", com a repetição dos sentidos impostos pelo professor. Para produção de autoria, as pesquisadoras defendem mudanças nas condições de produção de leitura e escrita na escola. Nas aulas observadas, percebemos que há a produção da obrigatoriedade de sentido, mas ao mesmo tempo, uma abertura para outros sentidos que aparecem com as vozes dos alunos, trazidas para o diálogo. Assim, acreditamos que quanto mais as vozes dos alunos puderem estar presentes, mais aberta poderá ser a relação com a linguagem escrita e seus múltiplos sentidos possíveis. Por outro lado, defendemos que a mediação das professoras, mesmo que acabe se tornando um controle dos sentidos possíveis, é necessária para que algum significado seja construído pelos alunos, de forma que a relação com os textos de Ciências possa se estabelecer. Analisando o texto do Caderno Pedagógico, sobre a atmosfera primitiva e suas transformações, descrito no trecho três, por exemplo, vemos que é composto por um gênero discursivo complexo, de difícil compreensão.

Professora lê o texto: Você sabe que nosso planeta já foi muito quente e sem vida. Muito tempo se passou até que seu resfriamento formasse a crosta terrestre. Mas não foi só a crosta terrestre do planeta que se modificou. A sua atmosfera também se transformou ao longo do tempo. $\mathrm{Na}$ formação do planeta Terra e da atmosfera, os vulcões tiveram um papel importante. $\mathrm{O}$ lançamento de gases formou a atmosfera primitiva, que era bem diferente da atual. Ela era composta por amônia, vapor de água, gás metano e gás hidrogênio, principalmente. Com o surgimento dos seres vivos, essa atmosfera primitiva foi sendo modificada, atingindo um determinado equilíbrio em relação à quantidade de gases que a compõem. Porém, o planeta Terra e seus ambientes são dinâmicos, isto é, estão sempre ativos, em transformação, podendo ser alterados por atividades naturais ou atividades humanas. 
Devido à complexidade do texto, com termos específicos e organização com características da linguagem científica (texto estruturado, bastante impessoal, com exceção da primeira frase, e com termos específicos do campo da Ciência), entendemos que o diálogo antes e após a leitura é importante para que seja de alguma forma compreendido pelos alunos. A partir do sentido do outro, os alunos buscam produzir seus próprios sentidos, em diálogo com os conhecimentos científicos. Para essa reflexão contribui o conceito de alteridade, central na teoria bakhtiniana. Existimos através do outro, construímos linguagem na interação com o outro, enunciamos em busca da resposta do outro, aprendemos a ler e a escrever a partir dos diálogos que estabelecemos com o outro. É com o outro que vamos explorando sentidos em práticas de leitura e de escrita. Nesse contexto, a mediação realizada pela professora é importante para trazer sentidos sedimentados, colocando-os em diálogo com sentidos produzidos pelos alunos, como o faz antes e depois da leitura em si.

As interações discursivas que ocorrem entre professoras e estudantes determinam a construção de conhecimentos escolares nas aulas de Ciências, principalmente aquelas estabelecidas através de textos escritos, como as apresentadas. Reconhecemos que diferentes instâncias e atores sociais, externos à escola, participam da regulação do conhecimento escolar; porém, defendemos que professoras e estudantes, como parte da cadeia discursiva, têm também participação ativa nesse processo, que envolve conflitos e embates. Assim, não só as questões estruturais determinam o trabalho realizado na escola, mas também as ações humanas, através da construção cotidiana do conhecimento escolar nas relações didáticas. Tais relações se expressam, por exemplo, na discussão em torno do resultado do experimento realizado em aula anterior (como vemos no trecho 1). A pedagogização nesse caso envolve a experimentação didática, atividade tradicional do ensino de Ciências, relacionada a aspectos sócio-históricos de desenvolvimento de metodologias ativas na disciplina escolar Ciências. No trecho dois, a pedagogização envolve associação com a história da Ciência, valorizada no ensino de Ciências com a ideia da ciência como atividade cultural humana. Já no terceiro trecho, o próprio texto informativo lido pela professora reflete as transformações que ocorrem na pedagogização do conhecimento. Analisando esses processos, é relevante perceber que o experimento realizado, a forma como a história das investigações de Priestley é contada e a maneira como as informações são descritas 
no texto do Caderno Pedagógico são próprios da escola. Isto é, são atividades elaboradas para fins de ensino, constituindo conhecimentos escolares em Ciências, muito diferentes dos conhecimentos acadêmicos. Os conflitos na mediação didática da sala de aula relativos à constituição do conhecimento escolar aparecem no trecho dois, no enunciado com o qual o aluno contesta o que a professora coloca ("Mas professora, e se ela for bem pequena?") ou no enunciado no qual uma nova informação é explicitada ("Tinha luz"). Aparecem também no trecho três, no questionamento sobre vulcões no Brasil, por exemplo ("A floresta não faz parte do Brasil, não?").

Assim, percebemos que as aulas de Ciências observadas acontecem como espaços dialógicos em torno da leitura e da escrita. O dialogismo nas aulas de Ciências se constitui especialmente com e a partir de textos escritos e determina a construção do conhecimento escolar em Ciências. A pedagogização dos conhecimentos nas salas de aula é também um processo dialógico e acontece em meio a interações entre professoras e estudantes, algumas conflituosas, envolvendo a linguagem escrita.

\subsection{1. Mediação da leitura e da escrita nas aulas de Ciências}

Em interlocução com o objeto de estudo da nossa pesquisa, é importante ainda aprofundar reflexões sobre a elaboração dos conhecimentos escolares na disciplina escolar Ciências através da linguagem escrita. As transformações didáticas que transformam o saber em conhecimento escolar dependem de modificações na linguagem, que ocorrem na formulação do discurso pedagógico. Os diálogos estabelecidos em sala de aula levam a essas transformações da linguagem e assim influenciam a formação do conhecimento escolar. Análises dos diálogos aqui transcritos sugerem que na produção dos discursos pedagógicos, gêneros primários se articulam com gêneros secundários do discurso. Nesse sentido, ao perguntar oralmente o que aconteceu com a vela no experimento que realizaram (trecho 1), a professora recebe dos estudantes uma resposta mais simples, mais relacionada à comunicação primária ("Apaga"); porém, ao indagar por que isso aconteceu, ao solicitar um modelo explicativo mais próximo do discurso da ciência, estimula os alunos a formarem gêneros mais complexos, mais 
associados a discursos secundários, inclusive com uso de signos relacionados ao campo científico, como gás oxigênio. Isso acontece também no trecho dois, quando a professora pergunta o resultado do experimento de Priestley e na discussão os próprios alunos trazem o termo fotossíntese como explicação para o resultado observado. No trecho três, a fusão entre discursos mais simples e discursos mais complexos aparece quando a professora faz uma pergunta complexa sobre o motivo da modificação dos gases da atmosfera, relacionada à gêneros secundários do discurso, e recebe dos estudantes respostas simples, formadas por uma única palavra, utilizada normalmente no cotidiano ("árvores, chuva, a gente"). Acreditamos que a hibridização entre conhecimentos cotidianos e conhecimentos científicos que se estabelece na produção do conhecimento escolar em Ciências, aparece na articulação entre gêneros primários e gêneros secundários do discurso, que pode estabelecer um novo gênero, que denominamos de forma ampla de gênero científico escolar. Consideramos que a elaboração desse novo gênero, mais complexo que o gênero primário do discurso, embora mais simples que o secundário acadêmico, pode participar do desenvolvimento da linguagem escrita, que é associada a formas mais complexas da linguagem. O diálogo a seguir, além dos três já transcritos, corrobora para a defesa desse argumento. Ele aconteceu em uma aula na qual a professora discutia com os alunos sobre doenças transmitidas pelo ar. A atividade pedagógica realizada era de leitura de uma imagem sobre caxumba que aparecia em um texto do Caderno Pedagógico (COORDENADORIA DE EDUCAÇÃO DO RIO DE JANEIRO, 2016 a, pg. 25). A imagem era formada por uma ilustração com indicação da glândula salivar inchada (com o termo glândula salivar escrito e apontando para a região) (FIGURA 1).

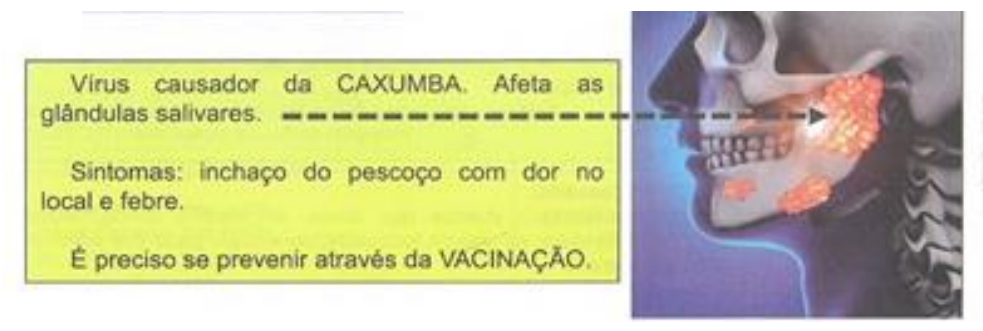

FIGURA 1: Imagem retirada da página 25 do Caderno Pedagógico de Ciências do sexto ano do ensino fundamental - $3^{\circ}$ bimestre/ 2016 - da rede Municipal de Educação do Rio de Janeiro.

"A professora fala sobre a caxumba. Conversa com os alunos. Chama atenção para imagem da página 25. Analisa a imagem.

Professora: E aí a famosa caxumba, que eu acho que vocês conhecem mais. 
Como a gente sabe que está com caxumba? Qual característica principal da caxumba?

Estudante A: Fica com essa parte aqui inchada. (Aluno aponta para bochecha).

Professora: Olha aí na imagem, que parte é essa que fica inchada.

Estudante A.: Bochecha.

Professora: Não é a bochecha não. É uma glândula que a gente tem aqui.

Estudante A.: Glândula salivar.

Professora: Isso. Tá?

Professora lê os sintomas na apostila Sintomas: inchaço do pescoço com dor local e febre. Depois pergunta: alguém já teve caxumba aqui?

Estudante B: Eu

Professora: Por isso você se lembrou da caxumba, né?

Estudante B: Não. É que eu fiquei com esses dois lados do pescoço inchado.

Professora: Mas não é só isso. Não é só um inchaço. Dificilmente passa para o outro lado.

Estudante B: É aqui embaixo.

Professora: Não, embaixo não. Olha a localização do inchaço aí na imagem. Olha aí na imagem. É no pescoço?

Estudante B: Não, mais para cima.

Professora: Exatamente". (Notas do diário de campo e transcrição de audiogravação).

Percebemos que há uma complexificação da fala do aluno quando ele se refere a um elemento cotidiano, isto é, bochecha, e a professora o ajuda a olhar para a imagem novamente e ler que parte estava indicada. Nesse momento, o aluno lê a imagem e fala glândula salivar. Assim, no diálogo com o texto, vemos uma articulação entre conhecimentos cotidianos e científicos na construção de conhecimentos escolares em Ciências e, nesse processo, o ensino-aprendizagem de leitura. Notamos que transformações da linguagem também ocorrem, articulando signos mais simples com outros mais complexos e gêneros primários (quando a professora conversa com os alunos sobre a doença) com secundários (quando lê o texto com estrutura elaborada).

É importante discutir que a distinção entre gêneros do discurso dimensiona esferas de uso da linguagem. Nesse sentido, como fruto das relações interativas vivas e dinâmicas, a classificação dos gêneros discursivos não é fechada, com limites precisos. Isso significa que sempre há alguma hibridização entre os gêneros (BAKHTIN, 2016). De acordo com a perspectiva bakhtiniana, os gêneros 
secundários são formações mais complexas da língua porque se originam na comunicação cultural organizada em sistemas específicos, tais como a ciência, a arte ou a política. Mas, isso não quer dizer que sejam refratários aos gêneros primários, afinal é comum que formas do mundo cotidiano façam parte da arte, da ciência ou da filosofia, por exemplo. As formas comunicativas estão sempre sujeitas a modificações, visto que são culturais, e assim, atravessadas por deslocamentos e transformações. Nesse contexto, os gêneros discursivos estão sempre mudando ao combinarem formas da comunicação oral imediata e formas escritas. Bakhtin discute que os gêneros secundários são originados a partir de gêneros primários, quando estes são modificados e reelaborados nos diálogos, de forma a perderem contato com a comunicação ordinária e passarem a fazer parte de textos escritos mais complexos, como um texto artístico, uma entrevista jornalística, um texto científico, etc.

Parece-nos que em diversos momentos nas aulas de Ciências ocorre um processo inverso, há uma tentativa de recontextualizar os gêneros secundários dos textos científicos escolares, trazendo gêneros primários para o diálogo. Assim, o gênero secundário dos textos da disciplina Ciências é posto em diálogo com discursos do cotidiano de estudantes e professoras (gênero discursivo primário), em uma tentativa de recolocá-lo na realidade concreta, na interação com outros enunciados (mesmo que diferentes daqueles que os originaram inicialmente). Nesse diálogo entre os gêneros, atividades de leitura e escrita se realizam, com a construção de algum sentido pelos alunos. A mediação entre os textos e os estudantes realizada pelas professoras ocorre especialmente através da articulação entre gêneros, em um processo no qual questões do cotidiano são trazidas para o diálogo em contradição aos textos científicos. Essa articulação foi observada em muitas atividades envolvendo leitura e escrita nas aulas de Ciências. Apresentamos a seguir outros exemplos dessa articulação. O primeiro diálogo foi transcrito de uma aula na qual a professora explicava um texto que tinha sido produzido por ela no quadro com definições de alguns conceitos ecológicos, entre eles o de ecossistema:

"Professora: Biosfera a gente chama do conjunto de todos os seres vivos do planeta. Se eu pegar todos os seres vivos que existem, desde a bacteriazinha até o ser humano, no planeta inteiro, vou chamar isso de biosfera. Então pensa, bio-esfera lembra a Terra toda, esfera. Então biosfera é o planeta inteiro, todos os seres vivos. E vou chamar de ecossistema quando em um lugarzinho específico esses seres vivos estão interagindo... O que é interagir? 
- Os estudantes ficam mudos.

Professora: O que é interagir pessoal?

- Os estudantes continuam mudos.

Professora: É o que vocês não estão fazendo comigo agora, né?

- Os estudantes riem muito.

Professora: Interagir é. Eu falo com a Maria Eduarda, a Maria Eduarda me responde. Eu pergunto, pessoal o que que é isso? Aí todo mundo me responde certinho, é isso aqui...

Estudante A: Ah tá!

Professora: Isso é interagir. Então por exemplo, você está conversando com um amigo seu, você está interagindo com ele. Você está oferecendo alguma coisa pra ele e ele está oferecendo alguma coisa pra você. Nem que seja uma conversa fiada.

Professora: Quando os seres vivos estão interagindo com o ambiente a gente chama isso de ecossistema. Como a gente interage com o ambiente? A gente que mora em uma área urbana, a gente interage com o ambiente?

Estudante B: Não sei.

Estudante C: Acho que não.

Professora: Interage pessoal com o ambiente? A gente mora num prédio fechado, a gente interage com o ambiente?

Estudantes: Não!

Professora: Não? Tem certeza? Todo mundo tem certeza que não?

Estudante C: Sim. Tenho certeza.

Professora: A gente interage com o ambiente sim. Independente da gente não estar na floresta, como o Tarzan de árvore em árvore, pendurado em um cipó, a gente interage com o ambiente. A gente não tá respirando? $\mathrm{O}$ ar não faz parte da atmosfera? A atmosfera não faz parte do ambiente?

Estudante A: Sim.

Professora: Então a gente está interagindo com o ambiente. A gente não bebe água? A água vem de onde?

Estudante D: Da chuva.

Estudante C: Da CEDAE

Professora: A água vem de algum lugar, de um rio, é encanada e chega até a gente. Então a gente tá interagindo com o ambiente. A gente come? $\mathrm{O}$ que vocês comeram hoje de manhã?

Estudante A: Pão.

Estudante E: Café.

Estudante C: Leite com Nescau.

Professora: O leite com Nescau vem da vaca. A vaca vem da onde? Então percebe que mesmo que a gente não more na floresta, a gente está o tempo todo interagindo com o ambiente. Aí, esse pedacinho de interação a gente chama de ecossistema. (...)". (Notas do diário de campo e transcrição de audiogravação).

A articulação entre os gêneros discursivos neste diálogo aparece, por exemplo, quando a professora explica o termo interagir, utilizado na definição de 
ecossistema, a partir do que acontecia naquele momento na sala de aula, trazendo elementos claros do diálogo oral mais simples ("É o que vocês não estão fazendo comigo agora, né?"). Ou ainda quando pergunta o que os alunos comeram naquela manhã. Partiu assim de um gênero discursivo secundário, que denominamos gênero científico escolar, para um gênero primário, e depois retornando ao gênero secundário, construindo o conhecimento nessa mescla e mediando a criação de sentidos pelos alunos em uma atividade de leitura.

Outro diálogo no qual observamos a articulação de gêneros discursivos ocorreu durante a discussão de um texto do Caderno Pedagógico sobre doenças transmitidas pelo ar (COORDENADORIA DE EDUCAÇÃO DO RIO DE JANEIRO, 2016 a, pg. 23).

“- A professora começa a trabalhar com a página 23. Lê uma parte do título.

Professora: Doenças transmitidas pelo ar. Vocês conhecem alguma doença que seja transmitida pelo ar?

Estudante A: Não!

Professora: É muito fácil.

Estudante B: Ah! Eu sei. A...

Estudante C: H1N1!

Professora: E o que é o H1N1? É um tipo de que?

Estudante C: De resfriado.

Professora: De gripe.

Professora: Doenças transmitidas pelo ar: gripe, resfriado...

Estudante C: Aqui tem. (mostra na apostila)

Professora: Eu sei, mas é pra vocês pensarem.

(...)

- A professora faz perguntas e dialoga com os alunos.

Professora: Vamos lá. Página 23 da apostila. Entre as doenças que são transmitidas pelo ar, umas das principais é gripe. Um tipo especial de gripe é um chamado H1N1. Especial por quê? Porque ela é causada por um vírus um pouco mais forte que os outros vírus normais de gripe.

Professora: Geralmente, quando a gente tá gripado, que que vocês sentem?

Estudante E: Nariz entupido.

Professora: Nariz entupido. Que mais?

Estudante C: Tosse.

Professora: Tosse.

A7: Espirra.

Professora: Isso. Febre, dói o corpo, cansaço.

Estudante F: A meleca desce! 
Professora: Isso. Forma um monte de meleca. O nosso próprio nariz que produz.

Professora: Por que na gripe, resfriado a gente forma uma maior quantidade de secreção?

Estudante G: Que é secreção?

Professora: Meleca.

Professora: Porque os vírus, eles incomodam e nosso corpo tenta jogar esses vírus para fora. Aí faz mais secreção, faz mais muco, que a gente chama de meleca. É a forma do nosso corpo tentar tirar do nosso corpo esses vírus que estão fazendo mal. A tosse também.

(...)

A professora segue e lê o texto ao lado: Aí aqui do lado, ó. O texto fala da H1N1. Ela lê o texto: A gripe H1N1 ou Influenza A é provocada por um vírus e transmitida como uma gripe comum por meio de saliva ou secreção nasal. Fala: Como a gente estava falando. Continua lendo: Os sintomas são febre, tosse, coriza e dificuldade para respirar. A pessoa com esses sintomas deve procurar um posto de saúde.

Aluno pergunta sobre uma palavra que aparece no texto: O que é coriza professora?

Professora: Coriza é o nariz escorrendo". (Notas do diário de campo e transcrição de audiogravação).

Nesse trecho a professora constrói um diálogo com os alunos primeiro buscando levantar conhecimentos prévios dos estudantes sobre o tema, a partir da discussão do título. Nesse momento há uma articulação de gêneros entre o título escrito, próximo de gêneros secundários (“Doenças transmitidas pelo ar”), e a conversa sobre doenças, compreendida como gênero primário do discurso. Depois continua o diálogo sobre sintomas da gripe, em um debate mais oral e cotidiano com os alunos ("Geralmente, quando a gente tá gripado, que que vocês sentem?"), que respondem utilizando gêneros primários (“A meleca desce!”). Depois, a professora segue complexificando o discurso, se aproximando de gêneros secundários, como vemos na parte na qual discute a formação de secreção para eliminação dos vírus do corpo. Depois disso, acontece uma atividade de leitura, que dialoga com o que tinham discutido até aquele momento. $\mathrm{O}$ texto lido pertence a um gênero discursivo secundário, estruturado e organizado. É um texto informativo com conteúdo científico, pertencendo ao denominado gênero científico escolar. A leitura ocorreu a partir das articulações anteriores que parecem ajudar os alunos a criarem sentido para o texto. Ao final do trecho transcrito, vemos um último hibridismo no qual o aluno questiona o significado de um termo e a professora busca 
uma explicação mais simples e cotidiana para ajudá-lo a dar sentido a esse termo (“O que é coriza professora? Coriza é o nariz escorrendo").

Em atividades de escrita observadas verificamos também a ocorrência de articulações entre gêneros discursivos primários e secundários. O exemplo abaixo foi transcrito a partir da correção de um exercício escrito no caderno que os alunos tinham feito em casa. Trata-se da correção da primeira questão do exercício.

"Professora: Primeira questão do exercício. O que é a combustão?

Estudante A: A combustão é uma reação exo-exotérm...

Professora: Exotérmica. Você sabe o que significa?

Estudante B: Eu botei que é um processo de queima.

Professora: Serve.

Professora: Exotérmica significa que libera energia, que a energia vai pra fora. Bota aí. Senão você vai esquecer o que é.

Professora: Alguém botou diferente?

Estudante C: Botei queima.

Professora: É um processo de queima, né? O que que se queima? A gente queima um...

Estudante B: Papel.

Professora: Um combustível. O papel pode servir de combustível, a gasolina, o álcool.

Estudante C: O óleo...

- A professora escreve no quadro depois do diálogo: É um processo de queima de combustíveis". (Notas do diário de campo e transcrição de audiogravação).

Nesta atividade de escrita, observamos que o diálogo entre a professora e vários estudantes alterna os gêneros discursivos que aparecem. A pergunta da professora e a resposta do Estudante A foram complexas, utilizando os termos combustão e exotérmica. Outros estudantes trouxeram respostas mais simples, utilizando o termo queima. Na discussão da questão apareceram gêneros primários relativos a conversa sobre o que se queima, na qual a professora pergunta o que se queima, um aluno responde papel e ela traz mais elementos, relacionando o papel a outros tipos de combustíveis. Quando produz uma resposta escrita final, faz mesclando elementos mais simples que apareceram no diálogo (queima) com outros mais complexos (combustíveis) ("É um processo de queima de combustíveis"). Mortimer et al (1998) nos ajuda a pensar em como a mediação é construída entre textos e estudantes nas aulas de Ciências. Como comentado anteriormente, em sua 
análise de respostas de vestibulandos, o autor mostrou que a linguagem científica e a linguagem comum são mescladas nas respostas dos alunos, o que pode indicar caminhos de apropriação da linguagem científica no ensino-aprendizagem de Ciências. Nos diálogos aqui transcritos, que revelaram hibridismos de gêneros discursivos, podemos também identificar a mistura da linguagem comum e da linguagem científica proposta pelas próprias professoras na tentativa de ajudar os estudantes a criarem sentido para os textos lidos ou escritos. Assim, aprendem Ciências e aprendem a ler e a escrever.

Em algumas atividades envolvendo leitura e/ou escrita nas aulas de Ciências, a articulação entre gêneros não ficou tão clara. Nestas houve o predomínio de gêneros secundários do discurso. Nas atividades de leitura isso aconteceu principalmente quando as professoras centralizaram a leitura e não conversaram com os alunos sobre os textos. Nas atividades de escrita, houve domínio dos gêneros secundários quando as demandas para produção textual solicitavam respostas curtas e objetivas com uso de termos científicos, sem abertura para autoria ou ainda quando se tratavam de atividades de cópias de textos. A seguir exemplos de uma atividade de leitura e de duas atividades de escrita nas quais apareceram predominantemente gêneros secundários do discurso. O primeiro trecho ocorreu em uma aula na qual a professora estava lendo textos do Caderno Pedagógico com os alunos. Em alguns momentos ela discutia os textos com os alunos e em outros apenas realizava a leitura. No trecho abaixo ela apenas leu o texto e fez um breve comentário, depois seguiu para outra discussão. Tratava-se de um texto sobre Ecologia do Caderno Pedagógico do quarto bimestre (COORDENADORIA DE EDUCAÇÃO DO RIO DE JANEIRO, 2016 b, pg. 19).

"A professora lê o quadro "Dica" e comenta o texto brevemente.

Professora: Aí tem uma dica aí do lado, ó. Lê: É fácil perceber que os seres vivos dependem dos fatores abióticos para viver. os fatores abióticos fornecem luz, calor, gases para respiração, e para realização do processo da fotossíntese; água para a composição dos seus corpos. Comenta: Então nenhum ser vivo, vive nem sem outro ser vivo nem sem os fatores não vivos". (Notas do diário de campo e transcrição de audiogravação).

Vemos que a voz da professora dominou a leitura. Ela leu o texto diretamente, sem trazer as vozes dos alunos para construção de sentidos junto com ela. O funcionamento da prática de leitura se tornou apenas a exposição de um 
conteúdo do Ensino de Ciências e não um espaço de uso e discussão da linguagem escrita. Com esse modo de ler não conseguimos perceber se os alunos estão construindo significado ao que leem, não há interação com o texto. Práticas de leitura como essa foram bem menos frequentes que práticas mais dialógicas e ocorreram principalmente em aulas nas quais as professoras trabalhavam com uma grande quantidade de conteúdos e textos, pressionadas pela chegada do fim do bimestre e das avaliações externas.

O trecho que apresentamos a seguir caracterizou também um momento mais monológico de uma aula observada. Ele se refere a uma atividade de escrita, na qual a professora produziu um texto para os alunos copiarem no caderno. Era um texto informativo composto por um gênero discursivo secundário sobre a relação entre respiração e fotossíntese. Antes de copiarem, a professora discutiu com os alunos uma imagem que trazia o mesmo conteúdo do texto escrito no quadro. Esse texto foi o momento final da aula, após ter dialogado bastante com os alunos sobre os sentidos construídos. O momento da escrita, no entanto, acabou se tornando apenas repetir o que a professora colocou no quadro e não uma produção mais autoral sobre o que tinham discutido e construído. A produção desse texto pode ter sido também uma forma de terem um registro do conteúdo, visto que faltam recursos para que a professora traga outros materiais, como cópias, livros, revistas, etc, como elas destacaram nas entrevistas (ver seção 4.1). Vemos que as vozes dos alunos apareceram apenas para protestarem pelo fato de estarem copiando, mas não para dialogarem sobre o texto em si.

“- A professora escreve um pequeno texto no quadro para os alunos copiarem ("A respiração e a fotossíntese"). Alunos copiam, mas reclamam no início. Depois começam a copiar. Ela cria o texto enquanto escreve no quadro - é um texto informativo de síntese do conteúdo trabalhado na aula.

Estudante A: Só tem isso?

Professora: Não, tem mais.

- Alunos seguem copiando enquanto a professora produz o texto no quadro.

Estudante A: Agora acabou?

Professora: Não.

Estudante A: Puxa!

(...)

Professora: Acabaram?

Estudante C: Ainda não professora, calma!

- A professora espera um tempo para todos os alunos copiarem. Fica 
sentada na mesa e deixa os alunos saírem para beber água e ir ao banheiro, um de cada vez (quem acabou de copiar)". (Notas do diário de campo e transcrição de audiogravação).

No terceiro exemplo, também de uma atividade de escrita, o predomínio de gêneros secundários ocorreu devido à forma do texto produzido. Tratava-se da correção de exercícios escritos do Caderno Pedagógico (COORDENADORIA DE EDUCAÇÃO DO RIO DE JANEIRO, 2016 a,pg. 20). A professora conversou com os alunos na correção das questões escritas, mas o diálogo se centrou nas respostas que exigiam uso de termos científicos, típicos de gênero secundário do discurso, sem aprofundar seus sentidos e usos.

“- A Professora lê as perguntas da página 20. Os alunos respondem oralmente. A Professora discute e depois, dita a resposta vagarosamente. Os alunos participam bastante. Após cada resposta, a professora espera um pouquinho para eles escreverem.

Professora: Aí tem as perguntas aqui. Vamos responder juntos. Prestando atenção pra responder direito.

Professora lê do Caderno: Primeira. Que processos, realizados pelos seres vivos, estão relacionados aos gases da atmosfera?

Estudante A: Respiração aeróbica.

Professora: Respiração... Que mais? Só respiração?

Estudante A: Aeróbica.

Professora: Mas isso é uma coisa só. Respiração Aeróbica. Tem mais dois!

Estudante A: É... Fotossíntese.

Professora: Fotossíntese e uso do nitrogênio atmosférico.

Professora: Respiração - vírgula - fotossíntese e uso do nitrogênio atmosférico (fala pausadamente)

Estudante B: Posso botar só atmosférico?

Professora: Nitrogênio atmosférico

Estudante C: Quê? Não entendi essa palavra

Professora: Nitrogênio atmosférico

Professora: e uso do nitrogênio atmosférico

Estudante C: Ni-tro-gê-ni-o atmosférico

Estudante B: É T mudo?

Professora: É

Professora: Número dois.

Professora lê do Caderno: Que gás o ser vivo utiliza na respiração aeróbica?

Estudante A: Oxigênio.

Professora: Gás oxigênio. Essa é a resposta.

Estudante C: Quê? 
Professora: Gás oxigênio.

Professora: Três.

Professora lê do Caderno: Que gás é eliminado durante a respiração aeróbica?

Estudante A: Gás carbônico.

Professora: Gás carbônico. Carbônico, tá? Gás carbônico. Não é carbono não. Assim ó! (escreve gás carbônico no quadro).

Professora: Quatro.

Professora lê do Caderno: As plantas respiram, como outros seres vivos?

Estudante B: Não.

Estudantes: Sim.

Professora: Sim. As plantas respiram, tá? As plantas respiram também. Então bota sim.

Professora: A cinco.

Professora lê do Caderno: O que a planta produz quando realiza a fotossíntese?

Professora: São duas coisas.

Estudante A: Oxigênio e...

Estudante B: Aquela gli alguma coisa.

Professora: Glicose. Pode botar alimento também, tá? E gás oxigênio.

Estudante B: Glicose, tá bem.

Estudante D: O que professora?

Professora: Glicose e o gás oxigênio.

Professora: Aí a seis.

Professora lê do Caderno: Que gás a planta consome quando realiza a fotossíntese?

Professora: Qual gás que ela usa?

Estudante A: O carbônico.

Professora: O gás carbônico.

Professora: A sete.

Professora lê do Caderno: Que gás a planta elimina quando realiza a fotossíntese?

Estudante B: Oxigênio!

Professora: O gás oxigênio

Professora: A última vocês vão procurar no texto, ó.

Professora: Aí a oito.

Professora lê do Caderno: Que seres vivos utilizam o gás nitrogênio?

Estudante A: Microrganismo.

Professora: Microrganismos". (Notas do diário de campo e transcrição de audiogravação). 
No trecho, percebemos que o diálogo se estabelece praticamente apenas com elementos trazidos de discursos mais complexos (com termos da linguagem científica, principalmente) e não de discursos cotidianos mais simples. Os alunos parecem estar se apropriando desses termos ao responderem as questões, mas não conseguimos perceber que significado constroem para eles. Como são perguntas simples e diretas, não é possível entender que sentidos estão construindo para esses conceitos. Cassiani-Souza et al (2012) discutem que suas investigações têm mostrado que o esperado em relação à leitura e à escrita nas disciplinas científicas é apenas a extração e repetição de informações úteis relacionadas ao conteúdo escolar de Ciências, foi o que parece ter ocorrido nesses exemplos de momentos mais monológicos das aulas.

Em comparação com momentos mais dialógicos das aulas, parece que, quando a mediação pelas professoras entre os textos e os alunos é construída trazendo mais as vozes dos alunos, a interação com os textos é vivenciada mais profundamente e o potencial para leitura e para escrita é ampliado. Autores que têm refletido sobre letramento e alfabetização, em abordagens bakhtinianas, trazem contribuições nesse sentido. Goulart (2003), por exemplo, discute a necessidade de ampliar o conceito de alfabetização para a noção de letramento, distinguindo o acesso à escrita enquanto tecnologia do acesso à escrita como prática social, que vai além do seu aspecto tecnológico. Nesse sentido, chama atenção para o viés político-ideológico envolvido na discussão sobre letramento. A autora destaca primeiramente a importância da escola se abrir para crítica, contradições e antagonismos, deixando aparecer interpretações diferentes, ou outros feixes de significações, revelando o que Bakhtin denomina de dialética interna do signo. Em segundo lugar, defende a ampliação da circulação de textos na escola, ampliando os diálogos dos alunos, com ênfase ao movimento da interdiscursividade. Em diálogo com a autora, defendo que momentos das aulas de Ciências nos quais houve incentivo para trazer as vozes dos alunos para o diálogo com os textos escritos - em movimentos de interdiscursividade, nos quais buscam aspectos da sua vida, de seus sistemas de referência para encontro com os textos -, são momentos que se aproximam mais de processos de letramento, nos quais os estudantes tem maior chance de se apropriarem da linguagem escrita e sua forma de organização do pensamento. Percebemos que a linguagem escrita de gêneros discursivos mais 
complexos parece ser mais difícil de ser elaborada pelos estudantes. A perda de relação com a realidade e os enunciados alheios na formação do gênero secundário parece dificultar a formação para leitura e escrita. Percebemos isso no último trecho, no qual os alunos expõem mais dúvidas (“Posso botar só atmosférico?”; "Quê? Não entendi essa palavra."; "Quê?”; "Aquela gli alguma coisa”.). Ao se distanciar da realidade, a língua perde seu caráter histórico e cultural constitutivo e se transforma em um código que se pretende homogêneo, se afastando assim das pessoas que a utilizam. As professoras tentam romper esse distanciamento no estabelecimento das mediações com os textos, trazendo outros elementos para o diálogo e interferindo assim na possibilidade de leitura e escrita, que é influenciada também por características da linguagem específicas das aulas de Ciências.

Há ainda outras questões que precisam ser consideradas nas reflexões sobre as relações entre ensino de Ciências e a linguagem escrita, que se referem ao tipo de conhecimento valorizado na escola. Os textos escritos que aparecem nas aulas, a maneira como a linguagem escrita é utilizada nesses espaços e os modos de ler e de escrever que são acionados se relacionam ao que se compreende socialmente como objetivos da escolarização e mais especificamente, objetivos de se ensinar Ciências, que por sua vez determinam os conhecimentos que circulam nesses espaços, tanto em relação aos conteúdos quanto aos métodos didáticos. Mesmo que as professoras não estejam refletindo sobre essa associação claramente, os materiais utilizados, os conteúdos abordados e as atividades pedagógicas realizadas, são legitimadas socialmente e influenciadas pela estrutura social, política, econômica e cultural que atua sobre a escola e sua comunidade. Nesse sentido, o que acontece nas aulas de Ciências, também relativo à linguagem escrita que ali circula, depende das tradições curriculares que historicamente foram sendo legitimadas e apoiadas no que se entende que sejam as finalidades da escolarização e da disciplina escolar Ciências. Para refletir melhor sobre isso, apoiamo-nos em Goodson (1995, 1997 e 2001), como dito anteriormente. O autor sistematiza três principais tradições curriculares que se articulam nas disciplinas escolares e fazem parte do conhecimento escolar: i) tradições acadêmicas, que priorizam conhecimentos teóricos e abstratos, estreitamente vinculados às universidades; ii) tradições utilitárias que focalizam conhecimentos profissionais e práticos; iii) tradições pedagógicas, que valorizam conhecimentos pessoais, sociais e comuns relativos a formas de aprender. As justificativas para determinadas escolhas curriculares de 
acordo com as tradições utilitárias e pedagógicas estão na relevância social e/ou pedagógica dos conteúdos e métodos de ensino. Já na finalidade acadêmica, as justificativas vêm das próprias ciências de referência. Goodson discute que as disciplinas escolares são "amálgamas mutáveis de subgrupos e tradições" (GOODSON, 1995, p. 120) que estão em constante disputa por recursos, status e territórios. Em meio a estes embates, diferentes tradições curriculares são produzidas, valorizadas e estabilizadas durante determinado período. Para o autor, esses mecanismos fazem com que as disciplinas escolares, ao amadurecerem e se consolidarem nos currículos escolares, se afastem do interesse dos alunos e das tradições mais utilitárias e pedagógicas, e se aproximem de uma tradição mais acadêmica, que lhes confere maior legitimidade. Em nossas observações, percebemos que conteúdos relacionados às tradições acadêmicas apareceram bastante. Porém, notamos também a ocorrência de muitas atividades com finalidades utilitárias e pedagógicas, mostrando que o desenvolvimento sócio histórico das disciplinas não é linear, ocorrendo uma mistura das tradições nos diversos estágios, mesmo quando a disciplina já se encontra bem definida no currículo, como destacam também os estudos de Selles e Ferreira (2005); Lopes (2007); e Gomes, (2008). Nas aulas que observamos, apareceram conteúdos e atividades pedagógicas que podem ser associadas às tradições acadêmicas e outros associados às tradições utilitárias e pedagógicas. Atividades de leitura e escrita ocorreram em articulação com as diferentes finalidades do ensino de Ciências, como vemos nas transcrições a seguir. No primeiro trecho mostramos uma atividade de escrita que estava em uma prova bimestral elaborada por uma das professoras. Essa questão parece se associar a tradições curriculares acadêmicas do ensino de Ciências, visto que o conteúdo está claramente associado à ciência de referência Ecologia:

“- Depois de distribuir as provas, a professora lê a prova com eles e diz que depois que ela explicar tudo, quem tiver dúvidas pode levantar o dedo. (...)

A professora explica a imagem da questão número dois e diz o que deve ser feito.

Professora: Vai olhar aqui no desenho do ecossistema, aqui não tá muito visível não. Mas, vamos ler junto aqui. Aqui é um lago, tem uma ave aqui na margem, dentro do lago tem um peixe grande, que é o número quatro. Tem uma planta no fundo do mar, que é uma alga que é o número um, tem um caramujo que é o número dois, pode colocar só o número, tá? Se não quiser escrever o nome. Tem o caramujo que é o número dois e tem um 
lambari.

Estudante A: Lamba...

Estudante B: Lambaria?

Professora: Lambari, que é o número três, tá? Então, o que que tá acontecendo aqui? O caramujo tá comendo a planta, o lambari tá comendo o caramujo, o peixe maior tá comendo ele, e a ave tá comendo o peixe maior, tá? Então, vocês têm que dizer aqui, o que que tá acontecendo, quem é o produtor, quem é o herbívoro, quem é o consumidor terciário e citar dois fatores bióticos e dois fatores abióticos. Beleza?". (Notas do diário de campo e transcrição de audiogravação).

O segundo diálogo foi transcrito de uma atividade de leitura e discussão em torno de um texto do Caderno Pedagógico sobre prevenção de doenças (COORDENADORIA DE EDUCAÇÃO DO RIO DE JANEIRO, 2016 a, pg. 23). Nele percebemos tradições mais utilitárias e pedagógicas, relativas a cuidados com o corpo.

“- A professora faz um "teatro" de transmissão de vírus de um para o outro. Os alunos prestam atenção e participam.

Professora: O vírus do meu espirro passou pra minha?

Estudantes: Mão.

Professora: E aí passei para

Estudantes: Mesa.

Professora: Aí, ele pegou botou a mão na mesa (...) aí foi no refeitório pegou uma maçã. Do meu corpo passou pra mesa, da mesa pra mão dele e aí ele não lavou a mão antes de comer, não lavou a mão antes de roer a unha, que não deve roer nem se a mão tiver limpa, antes de comer a fruta... Aí os vírus que estavam na mão dele foram pra onde?

Estudantes: Pra maçã.

Professora: E aí pro corpo dele. E aí? Ele poderia ter evitado isso?

Estudantes: Sim.

Professora: Lavando a mão, né? (...)

- A professora segue para leitura da apostila.

Professora: Então vamos ver aí, ó. Lê: Doenças transmitidas pelo ar. Previna-se.

Professora: Que que é prevenir?

Estudante A: Prevenir?

Estudante A: Eu sei que que é, mas não sei explicar.

Professora: Aprenda a não pegar. Faça, tenha atitudes que evite você pegar esse vírus.

Professora lê o texto da apostila com entonação. Lê e depois explica cada prevenção. Exemplos de diálogos estabelecidos: 
Professora lê: Evite colocar as mãos sujas nos olhos, boca e nariz.

Depois a professora fala: A mão de vocês está suja?

Alunos olham as mãos e respondem: Tá.

Outros dizem: Não.

Professora: Tá sim. Colocaram a mão em qualquer lugar, tá suja. Então antes de colocar as mãos nos olhos ou boca tem que lavar.

Professora lê: Não compartilhe objetos de uso pessoal.

Depois a Professora fala: Ou seja, se essa garrafinha aqui é do Caio, só quem pode beber?

Estudantes.: O Caio.

Professora: Isso. Posso ficar passando pras pessoas?

Estudantes: Não". (Notas do diário de campo e transcrição de audiogravação).

Nos dois diálogos podemos perceber como atividades de leitura e de escrita podem ocorrer associadas a diferentes finalidades ou tradições curriculares do ensino de Ciências. Porém, a linguagem parece variar dependendo da finalidade à qual a atividade está associada. No segundo diálogo, vemos que finalidades utilitárias favorecem enunciações com gêneros discursivos primários, pois mesmo os gêneros secundários escritos nos textos são mais simples. Já no diálogo anterior, sobre uma questão de prova, percebemos que finalidades acadêmicas aumentam a ocorrência de gêneros secundários no discurso da escola, pois demandam uma articulação com a linguagem científica, se aproximando mais de esferas complexas da linguagem. Finalidades utilitárias ou pedagógicas do conhecimento escolar são desenvolvidas com linguagem mais simples, visto que se relacionam mais diretamente com o contexto de vida dos alunos, já finalidades acadêmicas são desenvolvidas com linguagem mais complexa. Dessa forma, vemos que os modos de ler e escrever nas aulas de Ciências devem mudar também dependendo da finalidade com a qual a atividade está associada. Como essas diferentes finalidades influenciam nos diferentes conteúdos e métodos das aulas de Ciências, acabam por influenciar também as práticas de leitura e de escrita que ocorrem nesses espaços.

Em síntese, o dialogismo nas aulas de Ciências se estabelece em torno de textos escritos e permite que processos de ensino-aprendizagem de leitura e de escrita ocorram nesses espaços-tempo da escola. Percebemos que quanto mais as vozes dos estudantes aparecem nos diálogos, maior a interação com os textos e maior a possibilidade de leitura e escrita. A cadeia discursiva se constituiu nas aulas 
entre os discursos dos próprios alunos, entre os discursos dos alunos e da professora e entre estes e o discurso dos textos, ou ainda entre os discursos dos alunos e da professora e discursos de atividades realizadas anteriormente. $\mathrm{Na}$ mediação da interação entre os textos e os alunos, as professoras trazem elementos do cotidiano para os diálogos e a partir deles atuam na complexificação da linguagem. Nesse processo, realizam a articulação entre gêneros discursivos primários e secundários, de forma a contribuírem para que os estudantes construam sentidos para os textos que leem e escrevem. A linguagem escrita aparece nas aulas associadas às diferentes tradições curriculares do ensino de Ciências, isto é, acadêmicas, utilitárias e pedagógicas. Para ampliar as reflexões sobre as relações entre o ensinoaprendizagem desta linguagem escrita e o ensino de Ciências, analisamos atividades pedagógicas das aulas com mais profundidade, buscando elementos que nos ajudem a compreender aspectos mais específicos deste processo.

\title{
4.3.
}

\section{Atividades pedagógicas das aulas de Ciências e processos de leitura e de escrita}

\author{
"A gente vai aprendendo várias coisas \\ sobre isso, vai aprendendo palavras \\ novas, vai aprendendo a ler mais...". \\ (Fala de uma estudante do sexto ano do \\ ensino fundamental)
}

Diferentes atividades pedagógicas envolvendo leitura e escrita nas aulas de Ciências foram observadas durante a investigação, com objetivos, conteúdos e metodologias variadas. Para refletir sobre estas atividades, buscamos contribuições em estudos sócio-históricos do currículo. Apesar da investigação realizada não se encontrar no campo do currículo e não incluir um estudo histórico, autores deste campo nos ajudam a desnaturalizar os conteúdos e métodos que aparecem na disciplina escolar Ciências. Nesse sentido, contribuem para a compreensão de como determinados conhecimentos e metodologias de ensino se constituíram e se hegemonizaram nessa disciplina escolar. Como discutido anteriormente, especialmente a partir de Goodson (1995, 1997 e 2001), trabalhamos com a ideia de que as disciplinas escolares vão se constituindo historicamente em meio a embates por reconhecimento material e ideológico. Tais embates são influenciados por fatores culturais, sociais, políticos e econômicos das comunidades científicas, 
das instâncias de produção de materiais didáticos, do governo, das instituições escolares, da vida dos professores e estudantes, entre outros contextos, que acabam por determinar a constituição e a trajetória das disciplinas escolares. Os conflitos produzem uma certa estabilidade nos currículos das disciplinas, incluindo os conteúdos e métodos de ensino. Dessa forma, o currículo que é construído social e historicamente, sempre em mutação, acaba sendo ensinado como se fosse algo fixo e incontestável. Assim, as atividades pedagógicas que encontramos nas aulas de Ciências são fruto de estabilizações em meio a disputas que vem ocorrendo na disciplina Ciências ao longo do tempo. São atividades que foram sendo valorizadas e legitimadas dentro dessa disciplina ao longo de sua história e acabaram por constituí-la no presente. Interessa-nos olhar para essas atividades pedagógicas e pensar como dialogam com processos de leitura e escrita que acontecem no espaçotempo das aulas de Ciências. Analisamos também como as professoras desenvolvem essas atividades em suas aulas e que conhecimentos escolares em leitura e escrita produzem.

As atividades pedagógicas analisadas que envolveram processos de leitura e escrita nas aulas incluíram: i) o trabalho com textos a partir dos Cadernos Pedagógicos da Secretaria de Educação do município do Rio de Janeiro; ii) aulas práticas com experimentação; e iii) atividades avaliativas. A partir da próxima seção, analisamos estas atividades com mais profundidade, destacando aspectos específicos de ensino-aprendizagem de leitura e de escrita que apareceram. Ao final da última seção, analisamos uma atividade diferente das citadas, como representação de outras possibilidades que apareceram. Além destas, outros tipos de atividades didáticas ocorreram nas aulas, mas com uma frequência menor ou sem especificidades, no que se refere à apropriação da linguagem escrita.

\subsection{1. \\ Cadernos Pedagógicos de Ciências e possibilidades de leitura e escrita}

A maior parte das atividades observadas envolvendo leitura e escrita ocorreram com o uso dos Cadernos Pedagógicos de Ciências, elaborados pela Coordenadoria de Educação da Secretaria de Educação do município do Rio de Janeiro (COORDENADORIA DE EDUCAÇÃO DO RIO DE JANEIRO, 2016 a e b). Esse foi o principal material didático utilizado nas aulas de Ciências, 
especialmente nas Escolas 1 e 2. Na Escola 3, o Caderno não foi tão utilizado, muitas aulas aconteceram com outros tipos de materiais, como exposições com projetor, discussões e trabalhos em grupo, mas o conteúdo era semelhante ao proposto nos Cadernos. Assim, os Cadernos Pedagógicos, associados às avaliações externas, determinavam o conteúdo e a maioria dos textos utilizados. Observei 59 tempos de aula, dentre esses, em 32 tempos houve atividades com os Cadernos Pedagógicos, ou seja, em mais da metade dos tempos observados (aproximadamente 54\% dos tempos), o que mostra como esse material ocupou um espaço importante das aulas. Para o relato sobre a investigação destes materiais, dividimos a presente seção em duas partes. A seguir apresentamos os Cadernos Pedagógicos, discutindo o contexto de implementação nas escolas da rede municipal do Rio de Janeiro e as características dos textos que os compõem. $\mathrm{Na}$ seção seguinte, abordamos mais especificamente as estratégias e conhecimentos mobilizados em relação aos processos de leitura e de escrita que ocorreram com a utilização dos Cadernos Pedagógicos.

\subsubsection{1. Caracterização dos Cadernos Pedagógicos de Ciências}

A implantação de Cadernos Pedagógicos nas escolas da rede municipal do Rio de Janeiro começou em 2009, em um contexto de elaboração de políticas educacionais brasileiras articulado a reformas educativas neoliberais predominantes a partir da década de 1990 em diversos países, como discutido anteriormente com base em Luz (2016). Trazendo uma lógica mercadológica de resultados quantificáveis e cumprimento de metas para a educação, essas políticas foram desenvolvidas com a padronização dos currículos e realização frequente de avaliações externas associadas a bonificações docentes. Para essa padronização curricular, foram desenvolvidos os Cadernos Pedagógicos. São estes Cadernos que concretizam os textos curriculares oficiais da Secretaria de Educação do Rio de Janeiro, que incluem as Orientações Curriculares e os Descritores, e atrelados às avaliações externas, guiam o trabalho realizado nas escolas. Nos Cadernos são apresentados e trabalhados todos os conteúdos propostos nas orientações Curriculares, visando alcançar os objetivos traçados nos descritores. 
Inicialmente, os Cadernos Pedagógicos e provas bimestrais implementados foram apenas de Língua Portuguesa e Matemática para as turmas do $2^{\circ}$ ao $9^{\circ}$ ano do ensino fundamental, ambos elaborados pelo órgão central da Secretaria Municipal de Educação. Depois, entre 2009 e 2014, as políticas de implantação de Cadernos Pedagógicos foram estendidas para as disciplinas de Ciências $\left(4^{\circ}\right.$ ao $9^{\circ}$ ano), História e Geografia ( $6^{\circ}$ ao $9^{\circ}$ ano) e para as turmas de Alfabetização e Educação Infantil. Além destes, há os "Cadernos Especiais" que abrangem os Programas "Nenhuma Criança a Menos" (NCM), "Nenhum Jovem a Menos" (NJM), e "Educação de Jovens e Adultos" (EJA), e os Cadernos de Férias e o Caderno de Reforço Escolar. Nos primeiros anos, os Cadernos eram em preto e branco, mas quando foram adquirindo maior importância, a diagramação também mudou, ficando coloridos e mais ricos em imagens e figuras (LUZ, 2016). Assim, as turmas do $6^{\circ}$ ao $9^{\circ}$ ano do ensino fundamental são contempladas atualmente com cinco cadernos bimestrais: Língua Portuguesa, Matemática, Ciências, História e Geografia, sendo que História e Geografia não têm prova bimestral externa associada. Além da distribuição bimestral física, eles ficam disponibilizados online no sítio "Rio Educa", de acesso livre. Cada um destes cadernos é elaborado por uma equipe específica da Secretaria de Educação, constituída por professores da rede e por especialistas, de acordo com a disciplina. O professor regente recebe um caderno específico com orientações e sugestões para o trabalho pedagógico, diferente do caderno do estudante.

De acordo com Luz (2016), a implantação destes Cadernos começou como cadernos de apoio pedagógico, apenas para reforço de processos de ensinoaprendizagem. Mas, posteriormente, com a associação a avaliações externas bimestrais, foram se tornando cada vez mais centrais no trabalho pedagógico das escolas. A pesquisadora afirma, baseada na investigação realizada, que a adoção dos Cadernos Pedagógicos influencia o modo de se ensinar Ciências. Luz (2016) discute como seu uso diminui o desenvolvimento do Projeto Político Pedagógico de cada escola e, através da associação aos exames externos, acaba por determinar o que é ensinado nas escolas. Na investigação que realizamos também percebemos a centralidade dos Cadernos Pedagógicos nas aulas de Ciências, que foi norteador dos trabalhos desenvolvidos, especialmente em relação ao conteúdo e a ordem que era trabalhado. Afirmamos que, assim como influencia o modo de ensinar Ciências, 
os Cadernos também influenciam processos de leitura e escrita nas salas de aula, que ocorrem associados ao ensino de Ciências.

A pesquisa que realizamos mostrou também que as professoras buscam formas de resistência ao controle exercido pelo uso dos Cadernos e as avaliações externas. Para pensar sobre essas formas de resistência, propomos um diálogo com Kincheloe (2001), que analisa os trabalhos de Goodson e suas contribuições. O autor chama atenção para como Goodson aborda a questão do poder em suas teorias. O poder é complexo e ambíguo, sendo desenvolvido tanto pelos indivíduos e grupos dominantes, quanto pelos dominados, não sendo exclusividade nem de um grupo e nem de outro. Embora as relações de poder sejam desiguais, visto que as pessoas dominadas têm acesso restrito a qualquer sistema global de poder social, político, econômico ou educacional, os indivíduos e grupos-alvo nunca se tornam tão submissos como os que exercem o poder central gostariam, pois não deixam de possuir os seus próprios tipos de poder. Kincheloe (2001) resgata os conceitos de "poder imperializante" e "poder localizante" para essa reflexão. O "poder imperializante" seria exercido do topo para a base, se direcionando do exterior para o interior das relações e consciências. Já o "poder localizante" seria mais fraco, se direcionando da base para o topo e é exercido na tentativa de controlar o espaço imediato ao redor, incluindo pensamentos, identidade, sentimentos e interações sociais. Assim, o "poder localizante" seria um recurso social que desafia constantemente a influência dos detentores do poder mais forte. Discutindo os trabalhos de Goodson, o autor coloca que as matérias disciplinares teriam um "poder imperializante" que tenta colonizar o "poder localizante" dos professores e alunos que buscam tornar as disciplinas mais relevantes para sua vida cotidiana.

$\mathrm{Na}$ busca de resistência, as professoras pesquisadas exercem seu "poder localizante" ao trazerem outras atividades para a sala de aula, diferentes das propostas pelos Cadernos. Uma das professoras entrevistadas colocou na entrevista claramente a tentativa de exercer seu poder "localizante": "E aí quando eu consigo fazer uma coisa diferente, que eu já fiz por meio de texto, de vídeo eu também já fiz... que é uma forma também que eu tento escapar um pouco. Eu vou tentando encontrar momentos que eu possa escapar". Trouxemos essa fala anteriormente, quando discutimos que uma das dificuldades colocadas pelas professoras para realização de trabalhos com leitura e escrita nas aulas de Ciências era justamente esse controle sobre o seu trabalho. O controle é exercido também através do uso 
dos Cadernos. Assim, os momentos de "escape", aos quais a professora se refere, são os espaços para desenvolvimento de atividades diferentes das propostas nos Cadernos. Luz (2016) percebeu em sua pesquisa que as professoras complementam e agregam outras atividades ao que aparece nos Cadernos Pedagógicos, refletindo sobre a aprendizagem de seus alunos. Dessa forma, debate que os professores não adotam uma postura de submissão e total aceitação das políticas, mas tentam adequar e adaptar os conteúdos e materiais a sua realidade, mesmo enfrentando muitas adversidades. Da mesma maneira, na nossa investigação percebemos que as professoras "escapam" dos Cadernos, trazendo propostas de atividades diferentes daquelas que os Cadernos propõem. Dessa maneira se esforçam para produção e reflexão sobre seu próprio trabalho e mais uma vez mostram o comprometimento que possuem com o ensino-aprendizagem de seus alunos.

Além disso, percebemos, também como Luz (2016), que as formas de utilização dos Cadernos Pedagógicos eram diferentes para cada professora. Esteban (2014), ao discutir os modelos de políticas educacionais com grandes avaliações estandardizadas, coloca que levam a dois resultados principais, a normatização e a simplificação da educação. Porém, dentro da padronização, há espaços para pequenas especificidades locais. "Nesse projeto se configuram modelos de escolarização que valorizam a homogeneidade de processos, percursos e resultados, o que não exclui a possibilidade de pequenos e superficiais ajustes a determinadas características dos contextos em que se realizam" (ESTEBAN, 2014, pg. 467). Percebemos isso também na nossa investigação. Nas três escolas os conteúdos eram trabalhados na mesma ordem e ao mesmo tempo, porém as maneiras como o trabalho era realizado variava. Uma professora utilizava os Cadernos para leituras que ela mesmo realizava, trazendo pontos para o diálogo com os alunos, e depois em práticas de leitura e escrita que os alunos deveriam desenvolver individualmente. Outra professora usava o Caderno com maior intensidade de mediação, isto é, lendo os textos e fazendo perguntas para trazer as vozes dos alunos para dialogar com os textos. Mediava a maioria das práticas de leitura dos textos do Caderno e de produção textual. Intercalava o uso do Caderno (na leitura de textos, exercícios e realização das experimentações propostas) com atividades no quadro de cópia de textos que ela produzia e exercícios, e uso de vídeos. A terceira professora que participou da investigação utilizava o Caderno apenas para alguns exercícios de leitura e escrita que eram realizados 
individualmente pelos alunos. Nesse caso, embora o caderno fosse norteador do conteúdo trabalhado, quase todo o tempo das aulas era gasto com a realização de atividades elaboradas pela própria professora, como exposições com retroprojetor, propostas de trabalho em grupo e experimentos diferentes dos propostos no Caderno. Nessa escola, a presença de licenciandos realizando estágio na formação inicial na licenciatura em Ciências Biológicas gerou também esses “escapes”, com propostas que os professores em formação levavam.

\subsubsection{1.}

\section{Textos para leitura nos Cadernos Pedagógicos de Ciências}

Analisamos os Cadernos Pedagógicos de Ciências do sexto ano do ensino fundamental de 2016 , dos $3^{\circ}$ e $4^{\circ}$ bimestre. $O$ tema do Caderno do $3^{\circ}$ bimestre era atmosfera e, do $4^{\circ}$ bimestre, ecologia. Como acompanhamos apenas o segundo semestre letivo desse ano, analisamos os Cadernos desse período. Os Cadernos são compostos por textos escritos variados e imagens coloridas com exercícios associados, algumas propostas de aulas práticas de experimentação e ao final do material uma atividade extra de corte e colagem denominada "atividade de criação".

Buscamos classificar e agrupar os diferentes textos dos Cadernos em gêneros discursivos, tentando compreendê-los com mais profundidade. Analisamos os Cadernos Pedagógicos utilizados nas aulas observadas pensando sobre estes materiais na concretude da sua utilização, o que foi possível ao olharmos para eles refletindo sobre os momentos em que foram usados. Para Bakhtin-Voloshínov "qualquer que seja o aspecto da expressão-enunciação considerado, ele será determinado pelas condições reais da enunciação em questão, i. é, antes de tudo pela situação social mais imediata” ((BAKHTIN - VOLOCHÍNOV, 1990, pg. 112). Na reflexão sobre a situação social mais imediata, são elementos centrais os interlocutores da interação e os contextos sociais e históricos onde ela ocorre. São as esferas comunicativas específicas, representadas nestes contextos, que determinam os lugares sociais ocupados pelos parceiros da interação e suas relações hierárquicas, além das intenções comunicativas e processos ideológicos valorativos envolvidos nos temas e nas parcerias estabelecidas. $\mathrm{Na}$ investigação realizada, os interlocutores da situação comunicativa são as professoras, os estudantes e os textos em questão, produzidos por autores especialistas da Secretaria de Educação, que, 
nesse caso, acreditamos que funcionem também como interlocutores. A esfera comunicativa onde as situações acontecem é a escola, com as relações de poder que ali se estabelecem, entre as professoras e os estudantes, dos estudantes entre si e da Secretaria de Educação sobre as professoras e os estudantes, com seus mecanismos de controle através do uso dos Cadernos.

Encontramos gêneros discursivos variados dentre aqueles que foram utilizados em processos de ensino-aprendizagem envolvendo a linguagem escrita. Cada página dos Cadernos comportava diferentes tipos de gêneros discursivos. A seguir apresentamos um quadro que descreve brevemente características centrais dos gêneros observados nos materiais e utilizados em atividades de leitura e/ou escrita nas aulas observadas (QUADRO 8). Alguns destes gêneros foram criados por nós, a partir das observações e análises do campo de interação, dos interlocutores e dos estilos utilizados. Há nestes materiais outros gêneros, além dos que aparecem no quadro, porém não os incluímos, visto que não foram utilizados para nenhuma das atividades de leitura e escrita realizadas nas escolas. Após o quadro, comentamos mais profundamente as características destes gêneros discursivos para na próxima seção aprofundar de que forma foram exploradas nas aulas.

QUADRO 8 - Gêneros discursivos encontrados nos Cadernos Pedagógicos de Ciências dos $3^{\circ}$ e $4^{\circ}$ bimestres do $6^{\circ}$ ano de 2016 (COORDENADORIA DE EDUCAÇÃO DO RIO DE JANEIRO, 2016 a e b).

\begin{tabular}{|c|c|}
\hline Gênero Discursivo & Características principais \\
\hline Gênero científico escolar & $\begin{array}{l}\text { Textos escritos com objetivo principal de discutir } \\
\text { conceitos das ciências de referência. }\end{array}$ \\
\hline $\begin{array}{l}\text { Gênero informativo com } \\
\text { questões sociais. }\end{array}$ & $\begin{array}{l}\text { Textos escritos com objetivo de buscar } \\
\text { contextualizar o conteúdo das ciências de } \\
\text { referência com questões sociais e culturais (não } \\
\text { científicas). }\end{array}$ \\
\hline Fotografias & $\begin{array}{l}\text { Imagens fotográficas coloridas. Aparecem sempre } \\
\text { associadas a textos escritos. }\end{array}$ \\
\hline Ilustração & Imagens desenhadas. \\
\hline Esquemas & $\begin{array}{l}\text { Imagem que busca explicar algum processo ou } \\
\text { fenômeno. Além do desenho em si, há textos } \\
\text { escritos. }\end{array}$ \\
\hline Mapas & Representação de um lugar. \\
\hline Notícias de jornal & $\begin{array}{l}\text { Texto escrito retirado diretamente de um jornal ou } \\
\text { adaptado a partir deste veículo. Nos próprios } \\
\text { Cadernos os jornais aparecem como fonte. }\end{array}$ \\
\hline
\end{tabular}




\begin{tabular}{|c|c|}
\hline Atividades lúdicas & $\begin{array}{l}\text { Propostas de atividades de leitura e/ou escrita } \\
\text { associadas a brincadeiras de passatempo, como } \\
\text { cruzadinha, desenhar ou colorir e desembaralhar } \\
\text { letras. }\end{array}$ \\
\hline $\begin{array}{l}\text { Propostas de experimentação } \\
\text { escolar }\end{array}$ & $\begin{array}{l}\text { Textos com procedimentos de experimentação } \\
\text { escolar e perguntas associadas. }\end{array}$ \\
\hline $\begin{array}{l}\text { Propostas de exercícios de } \\
\text { síntese (escritos ou de marcação) }\end{array}$ & $\begin{array}{l}\text { Textos com perguntas escritas que busca recuperar } \\
\text { informações que foram apresentadas nas páginas } \\
\text { anteriores. }\end{array}$ \\
\hline Gráficos & $\begin{array}{l}\text { Representação visual de dados ou valores } \\
\text { numéricos. }\end{array}$ \\
\hline Propostas de uso de dicionários & $\begin{array}{l}\text { Textos com termos para que os estudantes busquem } \\
\text { seu significado no dicionário. }\end{array}$ \\
\hline Tabelas & $\begin{array}{l}\text { Textos organizados em formato de tabelas ou } \\
\text { quadros. }\end{array}$ \\
\hline História da Ciência & $\begin{array}{l}\text { Textos que fazem referências a experimentos } \\
\text { científicos realizados em outros momentos } \\
\text { históricos. }\end{array}$ \\
\hline
\end{tabular}

Destacamos inicialmente o gênero discursivo que denominamos gênero científico escolar, que foram predominantes dentre os textos escritos dos Cadernos Pedagógicos. Para classificação deste gênero consideramos: i) o campo de atividade no qual esses enunciados acontecem, isto é, a escola; ii) seu conteúdo temático, que em todos os textos deste gênero se relaciona a conceitos de campos científicos; iii) o estilo, que marca os textos desse gênero com estruturação próxima à linguagem científica; iv) a construção composicional, relacionada a modelos explicativos e informativos; e v) os objetivos dos enunciados, nesse caso o ensino-aprendizagem de conceitos relacionados às ciências de referência. Podemos considerar que engloba textos de gêneros distintos originalmente, como textos de divulgação científica e textos explicativos desenvolvidos para os Cadernos. Mas, com o mesmo campo de atividade, suporte, tipo de conteúdo, estilo, função e objetivos, foram reunidos como gênero amplo que denominamos gênero científico escolar.

Defendemos que o gênero que denominamos de gênero científico escolar tem relação com o gênero científico, mas é diferente dele, visto que ocorre em outro campo de atividade cultural, a escola, e mais especificamente, a disciplina escolar Ciências, e tem objetivos distintos dos enunciados dos campos científicos. Assim, da mesma forma que os conhecimentos escolares diferem dos conhecimentos científicos, o gênero científico escolar é distinto do gênero científico, embora traga traços do mesmo. Reconhecemos a instituição escolar como um campo de atividade 
culturalmente desenvolvido e complexo, de forma que possui um repertório de gêneros discursivos próprios e diferenciados, como o que chamamos de gênero

discursivo científico escolar. Parece-nos que esse gênero é do tipo secundário do discurso, visto que carrega características relacionadas ao discurso científico, bastante complexo de acordo com Bakhtin, e se caracteriza por elementos típicos da linguagem escrita e não da linguagem cotidiana oral. O gênero discursivo científico escolar é formado por enunciados em textos informativos que buscam explicar conceitos associados às ciências de referência, como vemos no exemplo a seguir, no texto intitulado "O ar e os seres vivos" (FIGURA 2): O AR E OS SERES VIVOS
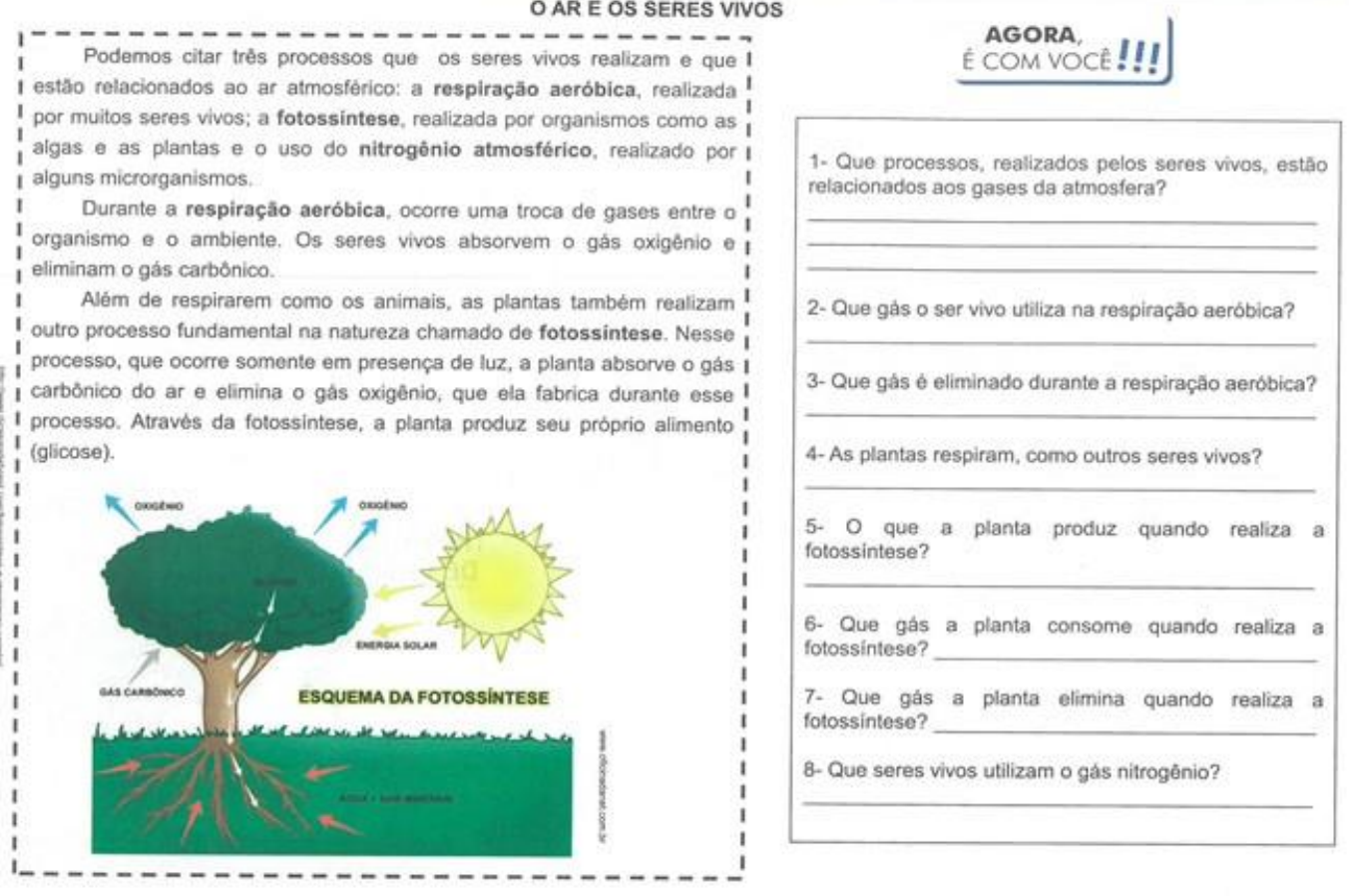

FIGURA 2: Página 20 do Caderno Pedagógico de Ciências do sexto ano do ensino fundamental $3^{\circ}$ bimestre/ 2016 - da rede Municipal de Educação do Rio de Janeiro.

Vemos neste texto termos relacionados à linguagem científica, como os signos: respiração aeróbia, fotossíntese, nitrogênio atmosférico, gás oxigênio e gás carbônico, entidades abstratas que costumam povoar as aulas de Ciências. Essas palavras caracterizam a expressividade típica do gênero discursivo científico. Porém, a forma na qual o texto do gênero científico escolar é escrito mistura características da linguagem científica e da linguagem comum (classificadas de acordo com Mortimer et al, 1998), que o diferem do gênero científico. Em relação 
à linguagem científica, percebemos a densidade léxica do texto (com muitos signos específicos de conhecimentos científicos) e algumas partes com estrutura típica desta linguagem, como a ausência do narrador (ou agente), a nominalização de processos e verbos que conectam esses processos nominalizados (MORTIMER et $a l, 1998)$. No texto acima destacamos o trecho "Durante a respiração aeróbica, ocorre uma troca de gases entre o organismo e o ambiente" como exemplo, no qual ocorre a nominalização dos verbos respirar e trocar e uma conexão entre os nomes com o verbo ocorrer. Porém, em outras partes do mesmo texto há características da linguagem comum, como partes com narradores presentes "Podemos citar..." e tentativa de dar uma sequência linear ao texto, por exemplo no trecho "Além de respirarem como os animais, as plantas também realizam outro processo fundamental na natureza chamado de fotossíntese". Apesar de trazer uma junção de características das linguagens científica e comum nos textos desse gênero discursivo, que denominamos gênero científico escolar, percebemos que no geral aspectos da linguagem científica são mais marcantes, como a densidade léxica e ausência de narrador. Como verificamos também no exemplo a seguir, com textos sobre o aquecimento global (FIGURA 3):
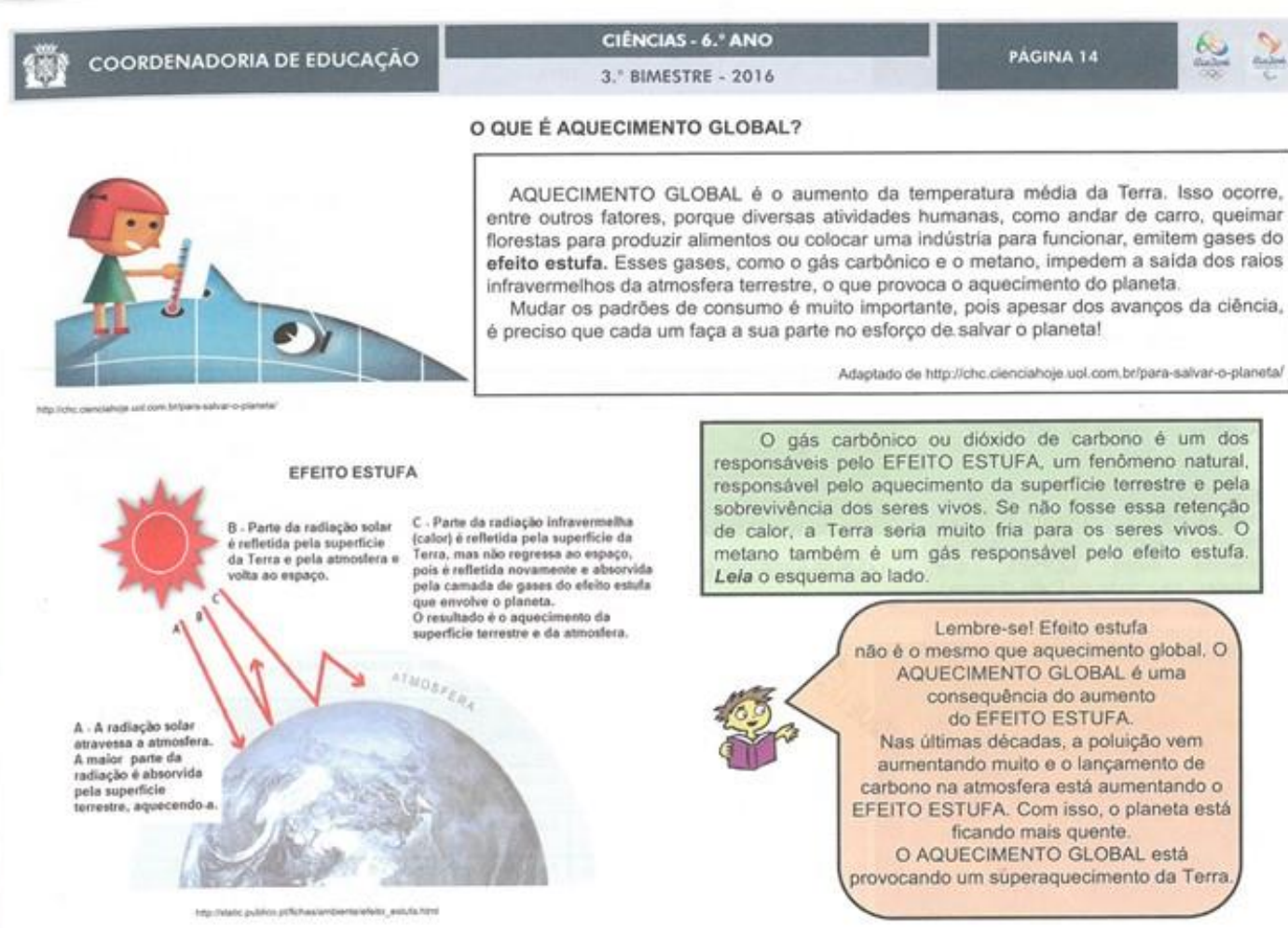

FIGURA 3: Página 14 do Caderno Pedagógico de Ciências do sexto ano do ensino fundamental $3^{\circ}$ bimestre/ 2016 - da rede Municipal de Educação do Rio de Janeiro. 
Nesta página, vemos características predominantes da linguagem científica, como os termos efeito estufa, gás carbônico, metano, raios infravermelhos, atmosfera terrestre e aquecimento global, e a ausência de verbos na primeira pessoa do singular ou do plural (ausência de narrador). Há vestígios da linguagem comum nos trechos "é preciso que cada um faça a sua parte no esforço de salvar o planeta" e "Lembre-se!", com estrutura linear sequencial e presença do sujeito, mas não predominam nos textos. O terceiro exemplo que apresentamos desse gênero discursivo aborda outro conteúdo temático, relacionado a questões de saúde (FIGURA 4):

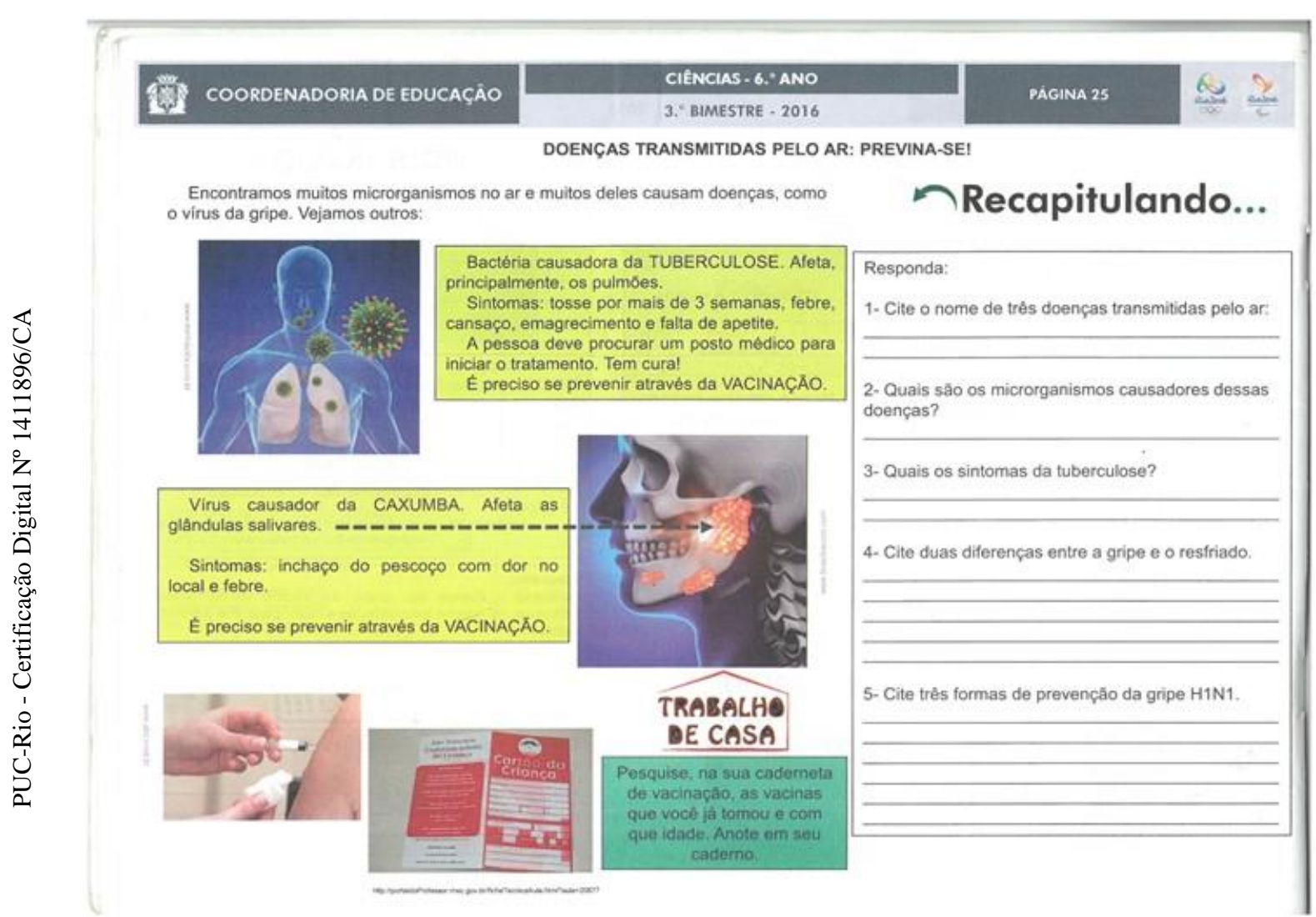

FIGURA 4: Página 25 do Caderno Pedagógico de Ciências do sexto ano do ensino fundamental $3^{\circ}$ bimestre/ 2016 - da rede Municipal de Educação do Rio de Janeiro.

Nesse exemplo, vemos mais trechos com características da linguagem comum que nos textos anteriores, como "A pessoa deve procurar um posto médico para iniciar o tratamento. Tem cura! É preciso se prevenir através da vacinação" e uma densidade lexical bem menor que nos dois primeiros exemplos. Mas há ainda traços marcantes da linguagem científica como os termos bactéria, vírus e glândulas salivares. Mesmo que a linguagem comum apareça mais nestes textos, o classificamos como gênero científico escolar porque o conteúdo temático se 
relaciona às ciências de referência e a composição é ainda marcada por estruturas explicativas e informativas relacionadas ao objetivo de ensinar conteúdos científicos. Além disso, trazem elementos de estilo que os aproximam da linguagem científica (mesmo que não tão fortemente como os textos anteriores).

Por fim, apresentamos um quarto exemplo, retirado do Caderno Pedagógico do $4^{\circ}$ bimestre (FIGURA 5).

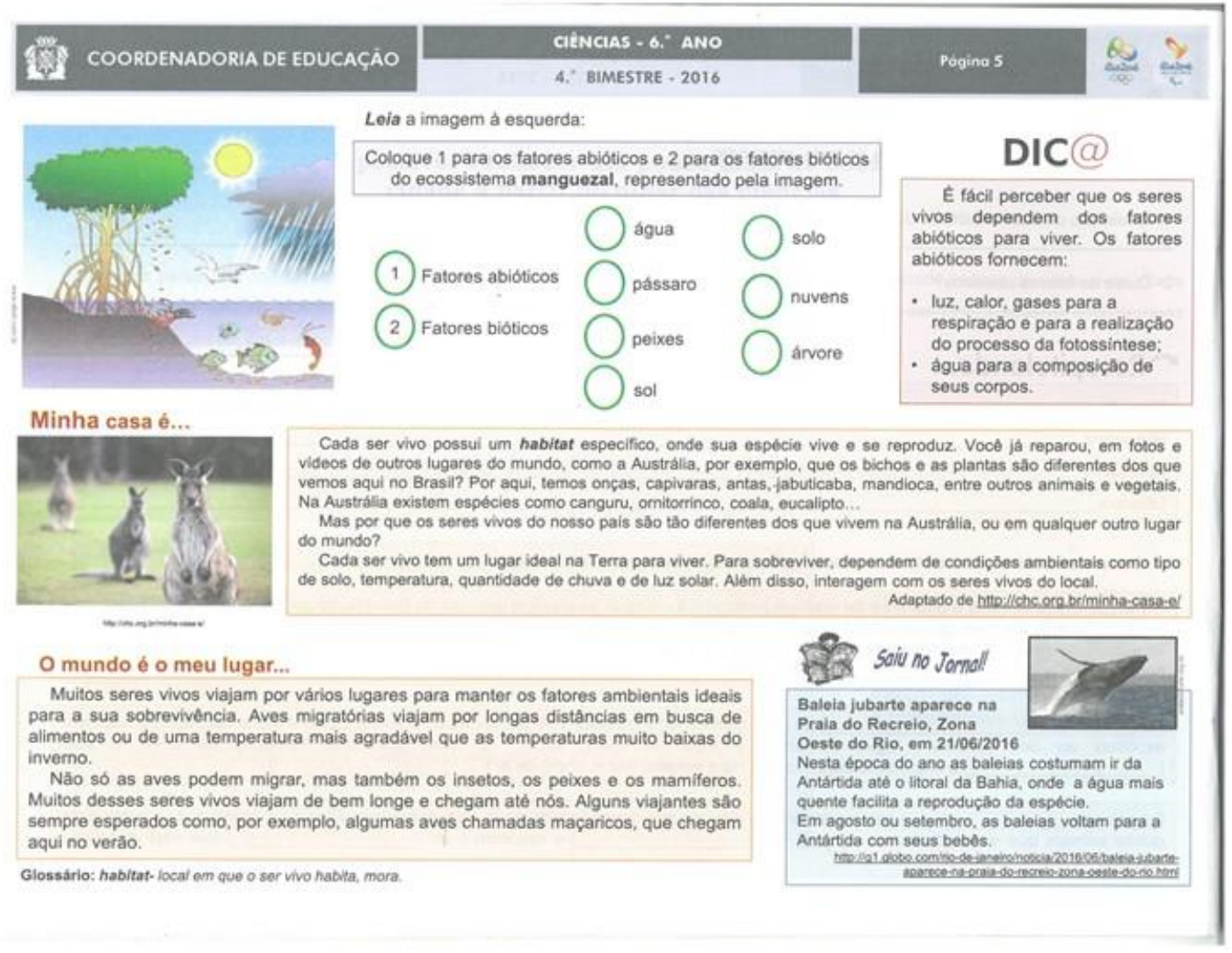

FIGURA 5: Página 5 do Caderno Pedagógico de Ciências do sexto ano do ensino fundamental - $4^{\circ}$ bimestre/ 2016 - da rede Municipal de Educação do Rio de Janeiro.

Nessa página, vemos outra vez termos característicos da linguagem científica (fatores bióticos, fatores abióticos, habitat, fatores ambientais, aves migratórias, gases, respiração, fotossíntese e ecossistema) e a mistura de estruturas típicas da linguagem científica com estruturas da linguagem comum. Nos textos "Minha casa é..." e "O mundo é o meu lugar..." a estrutura da linguagem comum aparece na presença do sujeito leitor "Você já reparou (...)" e de agentes na estruturação dos enunciados "Cada ser vivo possui (...)" e "Muitos seres vivos viajam (...)". No texto da seção “Dic@” a estruturação típica da linguagem científica aparece mais, por exemplo no trecho "os fatores abióticos fornecem luz, calor, gases para a realização do processo da fotossíntese". Mesmo nos textos que 
trazem mais elementos da linguagem comum desta página, ainda os entendemos como pertencentes ao gênero discursivo científico escolar porque eles têm como objetivo ensinar conceitos pertencentes ao campo da Ciência Ecologia, que embasa seus conteúdos temáticos, além de possuírem uma construção composicional explicativa. Assim, mesmo que os estilos variem um pouco em relação aos primeiros exemplos apresentados, visto que possuem uma estrutura mais próxima da linguagem comum, acreditamos que pertencem ainda ao mesmo gênero.

Os textos do gênero científico escolar são encontrados nos enfoques organizadores do currículo da disciplina escolar Ciências história natural, ecologia e anatomia, fisiologia e saúde humanas, classificados de acordo com Gomes (2008). No trabalho de Gomes (2008), o enfoque curricular da ecologia nos livros da disciplina escolar Ciências inclui visões de ensino e de ciência associadas ao campo científico da Ecologia Biológica e percepções relacionadas ao movimento ambientalista, articulando tradições acadêmicas, utilitárias e pedagógicas. O primeiro e o segundo exemplo do Caderno apresentados nessa seção (FIGURAS 2 e 3) se inserem nesse enfoque. O primeiro em um enfoque mais ligado ao campo científico da Ecologia e, portanto, a uma finalidade mais acadêmica. O segundo, sobre o "Aquecimento Global" se aproxima de finalidades acadêmicas ao explicar o que é o efeito estufa e suas relações com a retenção de raios infravermelhos e o aquecimento global. Mas, também se associa a finalidades utilitárias e/ou pedagógicas relacionadas ao movimento ambientalista, ao discutir a necessidade da mudança de atitudes e padrões de consumo. Os enfoques história natural e ecologia muitas vezes se sobrepõe nos Cadernos, ao discutirem aspectos da descrição dos seres vivos e do ambiente e relações entre eles, como Gomes (2008) também percebeu em sua pesquisa. Os textos do último exemplo (FIGURA 5) mistura aspectos desses dois enfoques. Por fim, o terceiro exemplo apresentado (FIGURA 4), se insere no enfoque anatomia, fisiologia e saúde humanas, ao trazer discussões sobre doenças. Esse enfoque nos Cadernos apareceu associado a finalidades acadêmicas (como a discussão sobre bactérias e vírus do exemplo) e também a finalidades utilitárias (por exemplo a colocação sobre a necessidade de buscar um posto médico e questões sobre vacinação). Assim, com esses exemplos, percebemos que os textos predominantes dos Cadernos Pedagógicos pertenciam ao gênero discursivo científico escolar, que carrega muitos aspectos relacionados à linguagem científica, articulados a trechos com características da linguagem 
comum, e se associa principalmente a enfoques acadêmicos, mas dialoga também com tradições utilitárias e/ou pedagógicas do ensino de Ciências na escola.

Nas páginas dos Cadernos apresentadas anteriormente, percebemos também que há uma grande quantidade de imagens. Vemos que estas aparecem articuladas a partes textuais escritas. As imagens analisadas nos Cadernos incluem os gêneros discursivos fotografias, esquemas e ilustrações. Para classificação destes gêneros, consideramos principalmente o estilo e a construção composicional do discurso. $\mathrm{Na}$ primeira página do Caderno exemplificada, percebemos um esquema da fotossíntese; na segunda, notamos um esquema do efeito estufa e uma ilustração do mesmo tema; na terceira, uma ilustração representando bactérias invadindo os pulmões, uma outra ilustração com a localização das glândulas salivares e fotografias de vacinação; e na quarta página exemplificada, uma ilustração de um manguezal e fotografias de cangurus e de uma baleia Jubarte. As imagens foram novamente apresentadas abaixo, para facilitar a visualização (FIGURA 6).
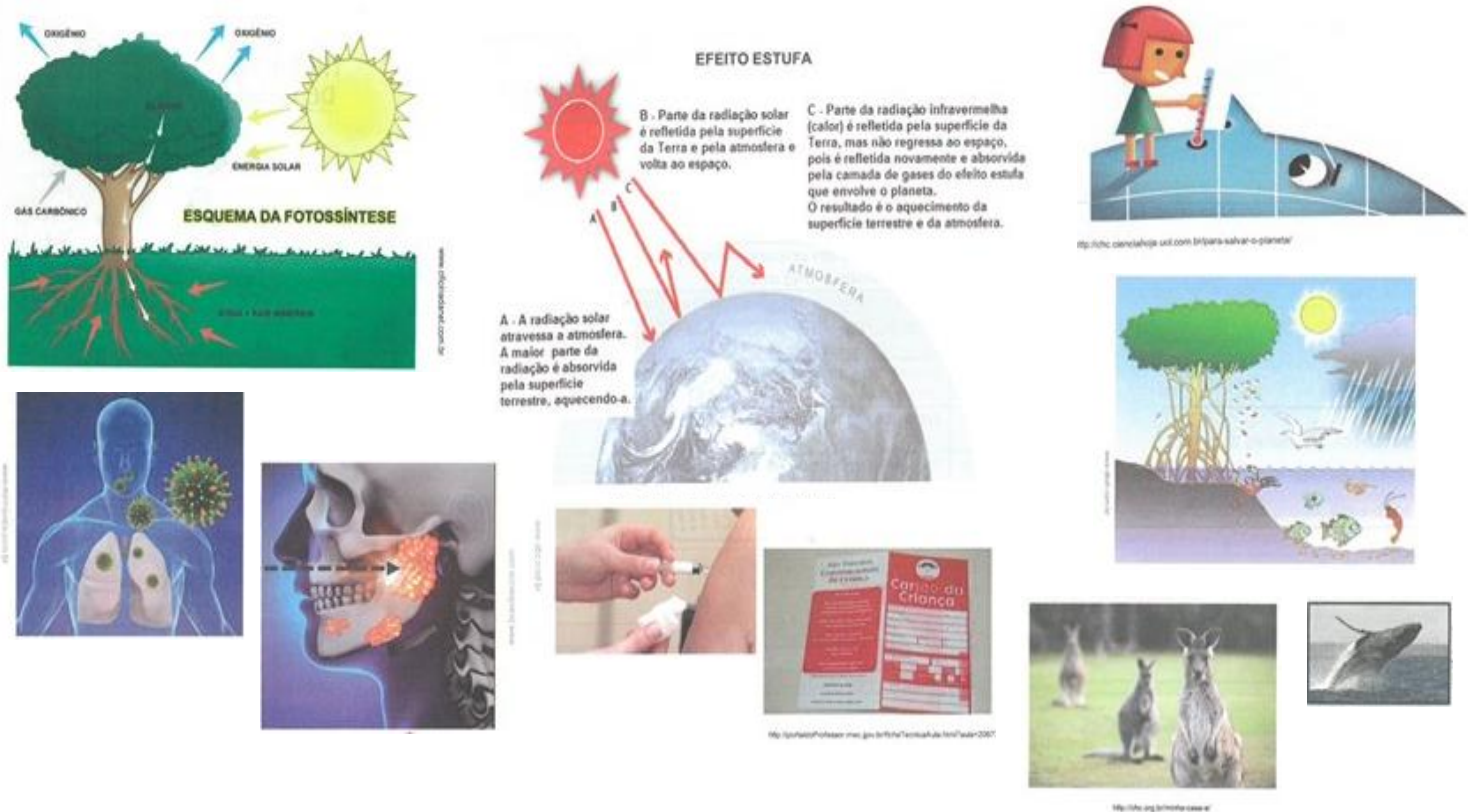

FIGURA 6: Exemplos de imagens dos Cadernos Pedagógicos de Ciências do sexto ano do ensino fundamental $-3^{\circ}$ e $4^{\circ}$ bimestres/ 2016 - da rede Municipal de Educação do Rio de Janeiro.

Dentre os gêneros discursivos imagéticos contabilizados nos Cadernos, as fotografias predominaram. Martins et al (2003), em investigação sobre imagens em livros didáticos de Ciências do terceiro e quarto ciclo do ensino fundamental, encontraram também uma maior frequência de fotografias em relação a outros tipos de imagens em livros do quarto ciclo. Algumas fotografias que observamos tinham como função evocar contextos do cotidiano e familiares que supostamente 
fazem parte do universo dos alunos, como fotografias de jogadores de futebol, de um ônibus, de lugares da cidade, ou a fotografia da caderneta de vacinação que aparece na figura acima (FIGURA 6). Outras tinham como função ilustrar, descrever cenários, seres vivos ou procedimentos que estavam nas explicações dos textos escritos, como as fotografias dos cangurus e da baleia (FIGURA 6). Dentre as ilustrações, havia as que tinham função de motivar ou despertar interesse dos alunos, como parece ser a do desenho do efeito estufa do planeta Terra com febre, que funciona como uma charge (FIGURA 6). Elas também aparecem com um aspecto mais realista para descrever alguns procedimentos, paisagens, seres vivos ou partes do corpo, como a das glândulas salivares e a do manguezal (FIGURA 6). Por fim, as ilustrações aparecem com a função de mostrar um modelo científico de algum fenômeno, como a ilustração de bactérias invadindo os pulmões (FIGURA 6). Os esquemas aparecem com a função principal de explicar fenômenos, como o de representação da fotossíntese e o do efeito estufa (FIGURA 6). Dentre estes, alguns tem aspecto sequencial, tipo uma narrativa de entidades abstratas, como o esquema que explica o efeito estufa. Além disso, os esquemas também aparecem nos Cadernos para descrever procedimentos de experimentação.

Vemos que imagens aparecem associadas aos enfoques curriculares descritos anteriormente, isto é, história natural e ecologia (por exemplo fotografias e ilustrações de seres vivos, paisagens e charges relacionadas a impactos ambientais; esquemas de processos relacionados aos seres vivos, como fotossíntese, respiração e cadeia/teia alimentar) e anatomia, fisiologia e saúde humanas (como ilustrações e esquemas de partes do corpo). Além disso, aparecem no enfoque ciência e experimentação que valoriza etapas que devem ser cumpridas tanto para a produção do conhecimento científico como para a aprendizagem das Ciências. Nesse caso, o enfoque se associa a ilustrações de procedimentos de experimentação escolar. As imagens também se articulam às variadas finalidades ou tradições curriculares do ensino de Ciências. Defendemos que algumas imagens se articulam a finalidades mais acadêmicas do ensino de Ciências, quando tem objetivo de explicar questões abstratas relacionadas aos campos científicos, por exemplo o esquema da fotossíntese e o esquema do efeito estufa. Em outras situações, as imagens se associam mais a finalidades pedagógicas e/ou utilitárias, como fotografias para descrição de seres vivos para as crianças ou ilustrações e fotografias de locais da cidade, trazendo questões do cotidiano. 
Outro gênero discursivo que se destacou na análise dos Cadernos foi o que denominamos gênero informativo com questões sociais. Engloba um conjunto de gêneros discursivos que, assim como o gênero científico escolar, também tem como campo de atividade a escola. Porém, eles se diferenciam no que se refere principalmente aos objetivos dos enunciados, que se associam a variações no conteúdo temático e no estilo dos textos. Esse gênero foi encontrado em textos que traziam questões culturais (não científicas) que se relacionavam de alguma forma ao tema do campo científico que estava sendo apresentado. Porém, a função central dos textos deste gênero não nos parece ser o ensino-aprendizagem de conceitos científicos específicos, como no gênero discursivo científico escolar, embora dialoguem com eles, mas sim a busca de alguma contextualização com outros aspectos da sociedade. Incluem, por exemplo textos com conteúdos temáticos como descrição de paisagens, formas de prevenção de doenças, informações sobre ecoturismo, curiosidades e dados das Olimpíadas (que ocorreram no ano dos Cadernos, 2016, no Rio de Janeiro), entre outros. Em relação ao estilo e composição, não trazem características típicas da linguagem científica, como signos específicos de campos científicos e nominalização dos processos, se aproximando mais da linguagem comum, quando comparado ao gênero discursivo científico escolar. São também textos informativo e explicativos, como os do gênero científico escolar, mas não compõem explicações de conceitos científicos, mas de questões sociais e culturais (não científicas). Com a estrutura explicativa e informativa da linguagem escrita, os textos deste gênero também pertencem a gêneros secundários do discurso, mesmo que a estruturação se aproxime mais da linguagem comum do que científica. O gênero discursivo informativo com questões sociais está mais próximo de gêneros primários que o científico escolar, mas sendo um gênero escrito e informativo, é ainda um gênero secundário do discurso. A seguir apresentamos um exemplo (FIGURA 7): 

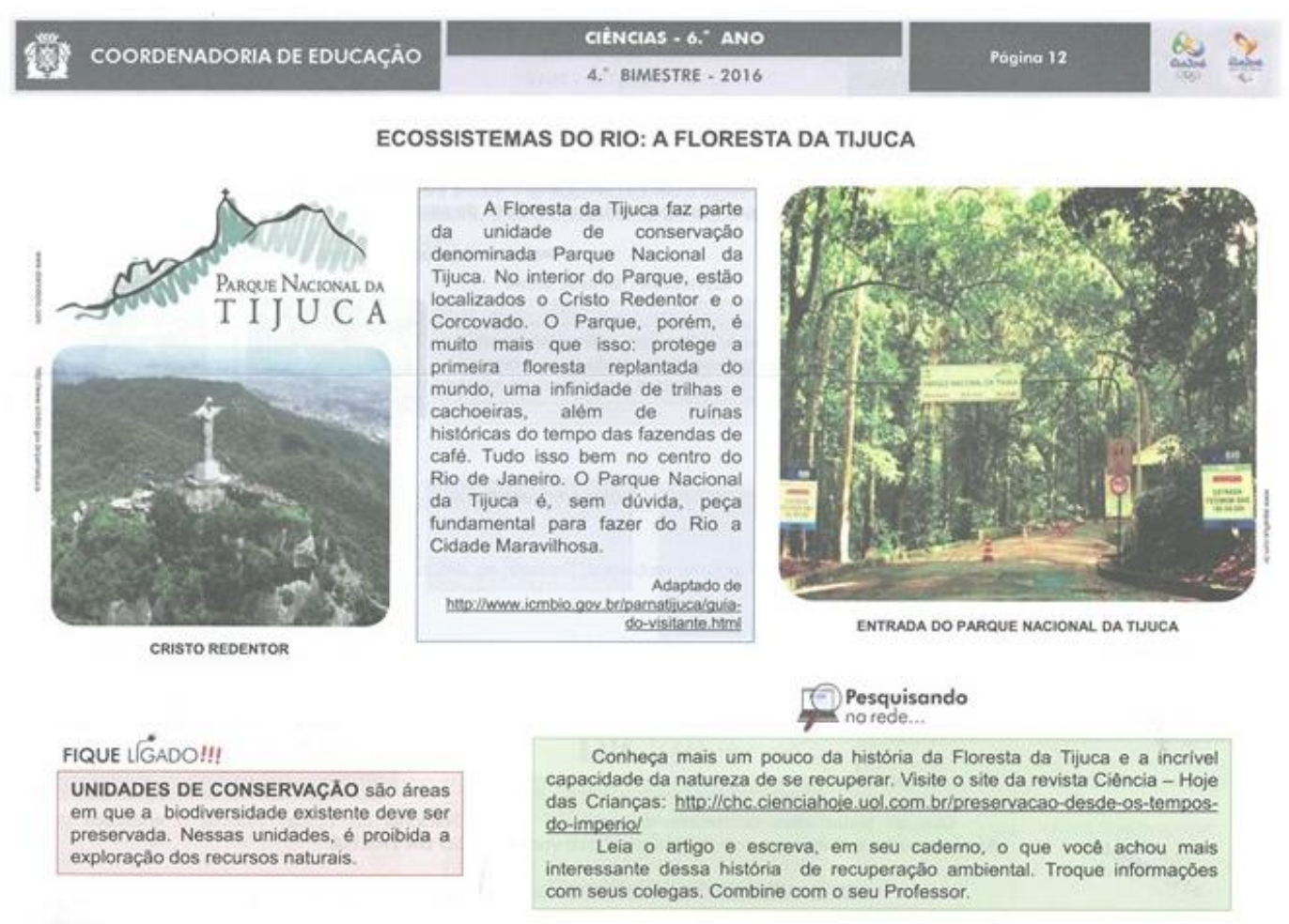

FIGURA 7: Página 12 do Caderno Pedagógico de Ciências do sexto ano do ensino fundamental $4^{\circ}$ bimestre/ 2016 - da rede Municipal de Educação do Rio de Janeiro.

O texto central da página "Ecossistemas do Rio: a Floresta da Tijuca" foi categorizado como pertencente ao gênero discursivo informativo com questões sociais. Ele descreve o Parque da Tijuca, expondo alguns de seus atrativos (como Cristo Redentor, Corcovado, trilhas e cachoeiras e ruínas históricas) e trazendo informações sobre sua história (maior floresta replantada do mundo). Além disso, o texto parece procurar enaltecer o parque da Tijuca ("fundamental para fazer do Rio a Cidade Maravilhosa"). O título sugere um diálogo com o conceito de ecossistemas que está sendo apresentado no Caderno, mas o objetivo central é descrever o local como um parque da cidade do Rio de Janeiro e não discutir o conceito de ecossistema. Nesta mesma página, há outro texto que classificamos como pertencente a este gênero discursivo, que aparece na seção "Fique Ligado". O seu objetivo é explicar o significado do que seja uma unidade de conservação, dialogando com o conteúdo de biodiversidade. Nos dois textos percebemos que a estrutura se aproxima da linguagem comum, em comparação com características da linguagem científica, conforme discutido em Mortimer et al (1998). Destacamos a presença de agentes da ação, como a floresta, o Corcovado, o Cristo e o parque e a ausência de palavras peculiares de campos científicos. 
No segundo exemplo, apresentado a seguir, há dois textos deste gênero. $\mathrm{O}$ texto com o título "Competição" e o com o título "Cooperação" (FIGURA 8).

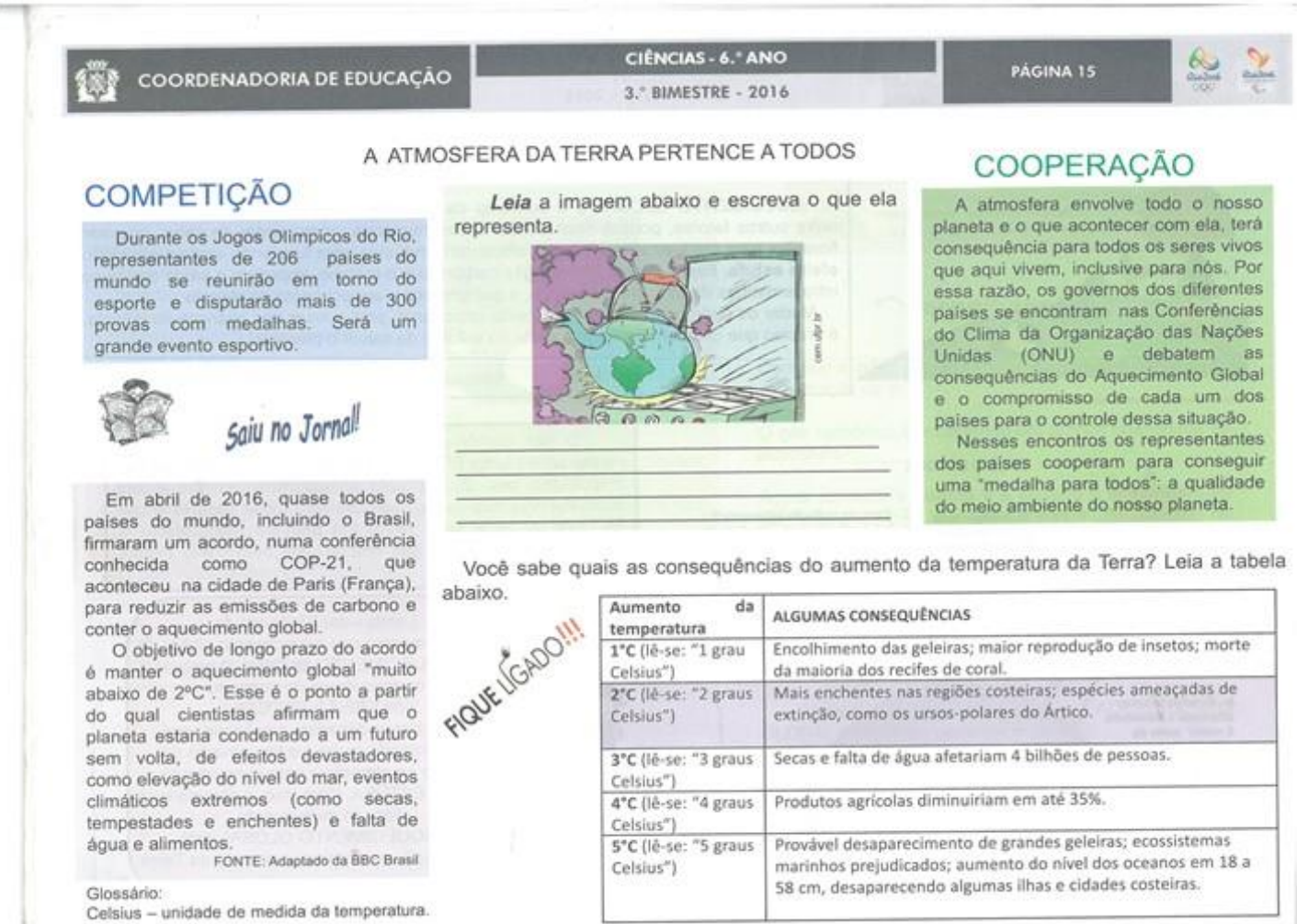

FIGURA 8: Página 15 do Caderno Pedagógico de Ciências do sexto ano do ensino fundamental $3^{\circ}$ bimestre/ 2016 - da rede Municipal de Educação do Rio de Janeiro.

O texto "Competição" traz dados sobre as Olimpíadas, não estando claro com que conceito científico se estabelece um diálogo nesse caso. Indiretamente, podemos supor que o título "A atmosfera da Terra pertence a todos" cria uma associação entre a ideia de que a atmosfera terrestre pertence a todos e o fato de que nas Olimpíadas, de acordo com o texto do Caderno, "todos" estarão reunidos (destacando o grande número de países representantes). Mas, essa articulação fica muito distante e o texto parece ter muito mais a função de exaltar as Olimpíadas do que contextualizar conceitos de temas de conteúdo científico. O texto "Cooperação" já se associa mais fortemente ao conteúdo do campo das ciências que vinha sendo discutido, a atmosfera. O primeiro parágrafo constrói claramente essa associação ("A atmosfera envolve todo o nosso planeta e o que acontecer com ela, terá consequência para todos os seres vivos que aqui vivem, inclusive para nós"). O texto também busca uma articulação com o texto anterior (“Competição") ao mencionar "uma medalha para todos" na conclusão. A discussão principal, porém, não é exatamente sobre conceitos científicos relacionados à atmosfera, mas 
sobre as Conferências do Clima das Nações Unidas (ONU). Nestes, notamos também a presença de agentes que executam as ações, como os países no primeiro texto e os governos no segundo, e a baixa densidade léxica em relação a termos científicos (só atmosfera e aquecimento global no segundo texto), aproximando-os da linguagem comum e não científica.

A seguir mais exemplos deste gênero discursivo na seção "Fique Ligado" o texto com título "Doenças transmitidas pelo ar: previna-se" (FIGURA 9):

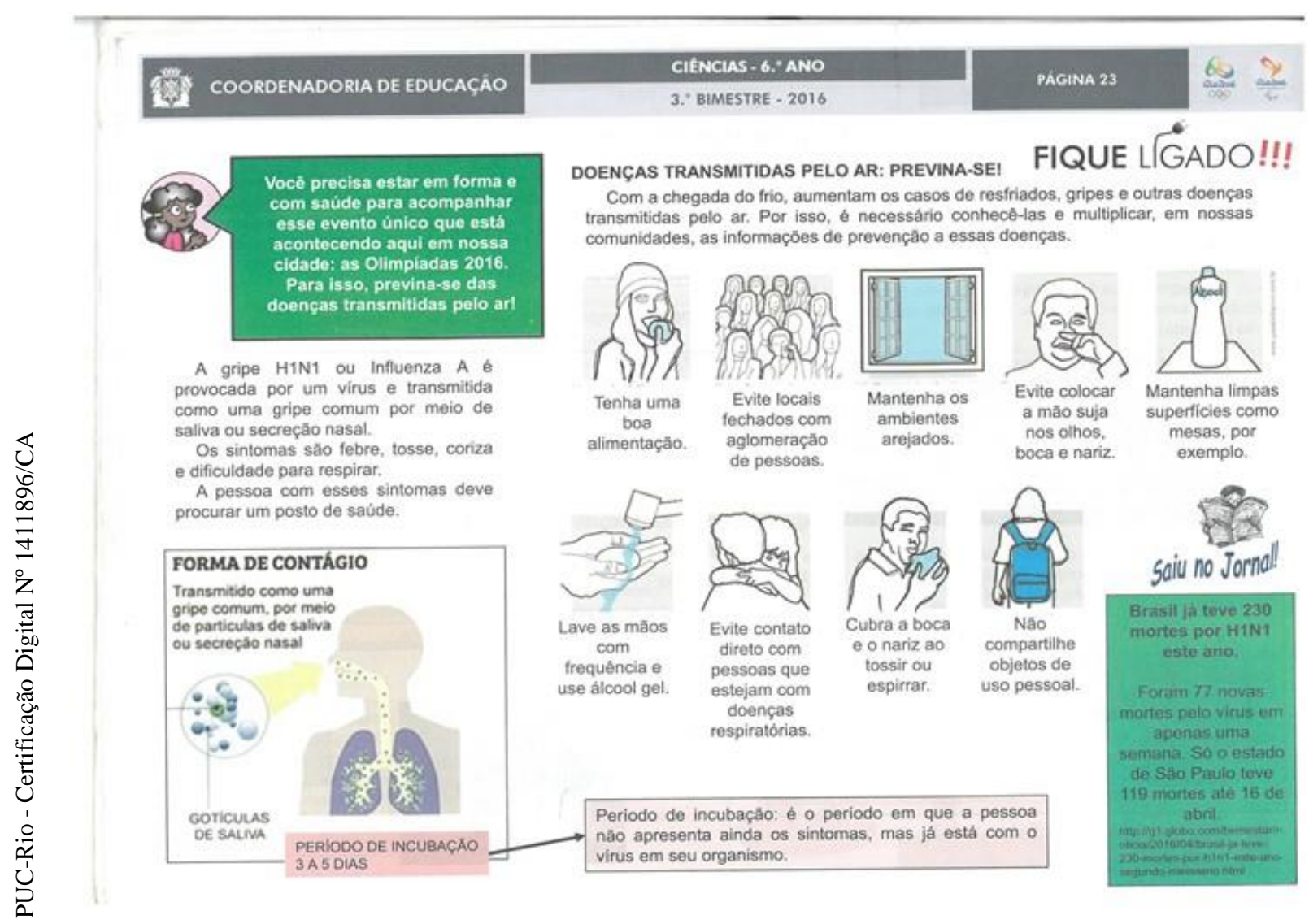

FIGURA 9: Página 23 do Caderno Pedagógico de Ciências do sexto ano do ensino fundamental $3^{\circ}$ bimestre/ 2016 - da rede Municipal de Educação do Rio de Janeiro.

No texto exemplificado, há atitudes comportamentais para prevenção de doenças transmitidas pelo ar. Este texto tem o objetivo claramente utilitário de mudança de hábitos e não a discussão de conceitos científicos. A relação com o conteúdo científico aqui se estabelece no estudo do ar, da atmosfera terrestre. Mas, mais uma vez não é a finalidade principal do texto. Se relaciona à linguagem comum ao se dirigir diretamente ao estudante-leitor com verbos no imperativo (tenha, evite, mantenha, lave, etc.). 
O quarto exemplo do gênero discursivo informativo com questões sociais aborda mais uma vez o tema das Olimpíadas, como vemos no texto "Como ficará o tempo no período das Olimpíadas Rio 2016” a seguir. Nesta mesma página há o texto "Você sabe a diferença entre tempo e clima? " que também pertence ao gênero mencionado (FIGURA 10):

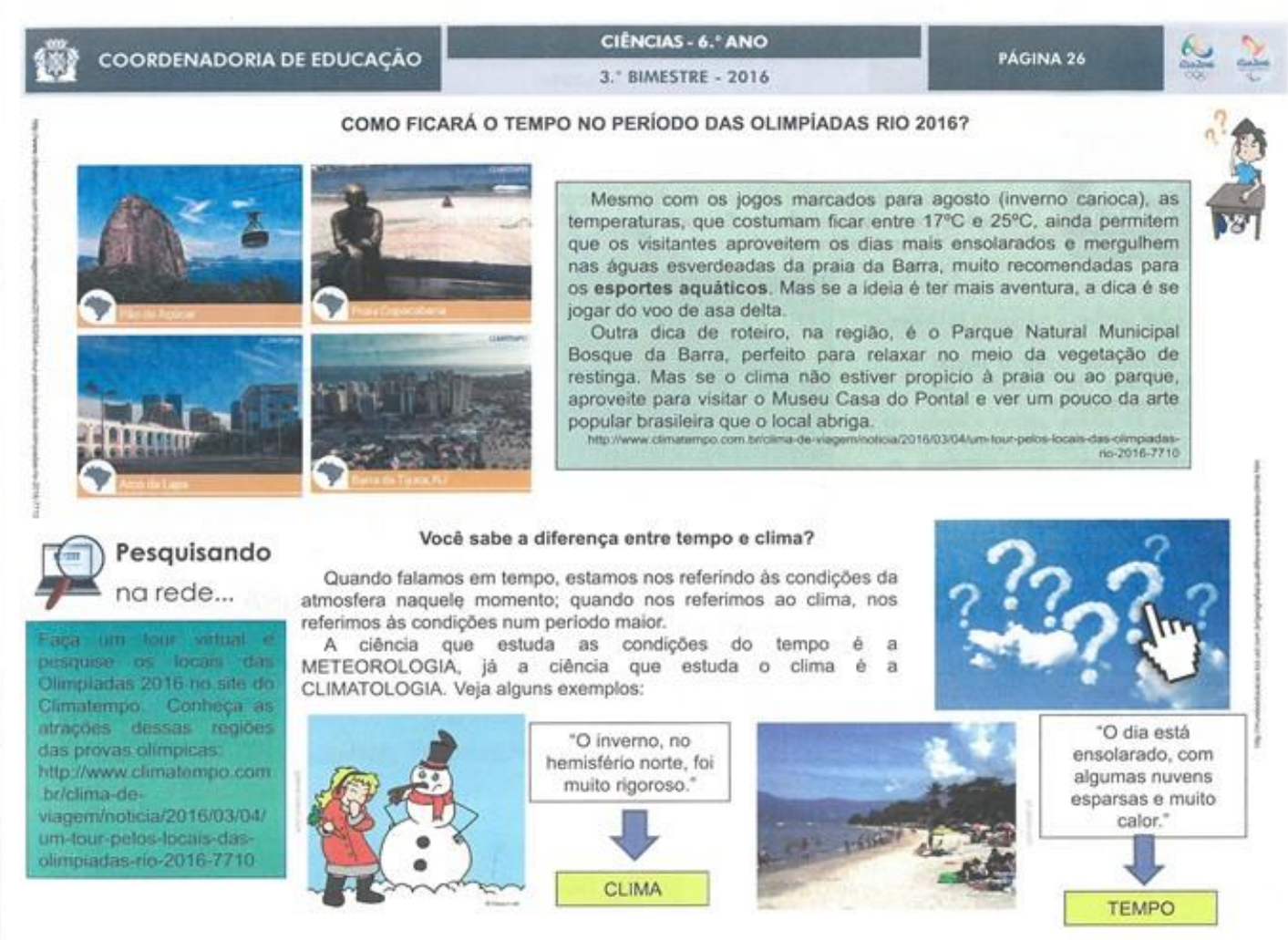

FIGURA 10: Página 26 do Caderno Pedagógico de Ciências do sexto ano do ensino fundamental $3^{\circ}$ bimestre/ 2016 - da rede Municipal de Educação do Rio de Janeiro.

No primeiro texto exemplificado, as Olimpíadas são referência para o título e para a discussão sobre a temperatura no período dos jogos. O texto dialoga com o conteúdo de clima e tempo, abordado no Caderno. O segundo texto informa sobre as diferenças entre clima e tempo e nomeia as ciências meteorologia e climatologia. Ambos trazem características marcantes da linguagem comum, como os agentes da ação (visitantes no primeiro texto e nós no segundo) e sequência linear de eventos, marcada pelos termos ainda, mas se, quando e já. No segundo texto, há a marca de termos científicos, como atmosfera, climatologia e meteorologia, mas a estrutura se articula mais fortemente à linguagem comum.

Por fim, como último exemplo, destacamos o texto "Fique ligado", com dicas para proteção da pele aos raios ultravioletas (FIGURA 11): 


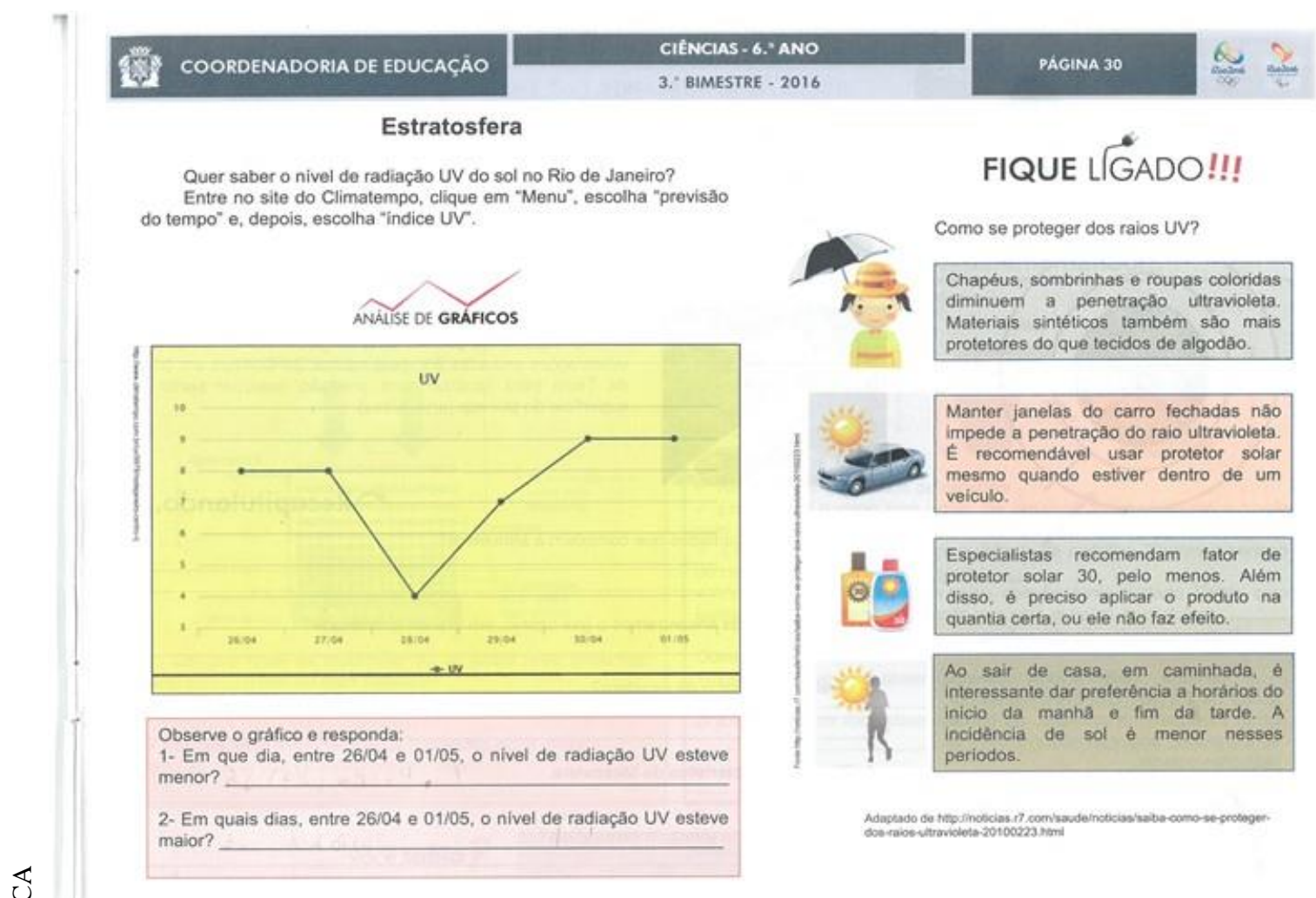

FIGURA 11: Página 30 do Caderno Pedagógico de Ciências do sexto ano do ensino fundamental $3^{\circ}$ bimestre/ 2016 - da rede Municipal de Educação do Rio de Janeiro.

Este exemplo se associa ao conteúdo raios ultravioletas, estudados na disciplina Ciências na discussão sobre a atmosfera. A finalidade principal do texto, no entanto, não é o ensino-aprendizagem deste conteúdo, mas sim debater comportamentos relacionados a questões de saúde. Aproxima-se da linguagem comum ao se dirigir ao leitor, o estudante, para que se proteja dos raios ultravioletas (raios $U V)$.

Em todos os exemplos de textos reunidos no conjunto gênero discursivo informativo com questões sociais, vemos que, embora haja articulação com finalidades acadêmicas do ensino de Ciências refletidas nos termos científicos utilizados (por exemplo ultravioleta, atmosfera e ecossistema), as finalidades centrais são pedagógicas e/ou utilitárias, relacionadas aos objetivos de descrição do mundo para as crianças, discussão de questões de saúde, discussão de comportamentos, etc. Além disso, dentre as finalidades, percebemos a relação com outros objetivos da escolarização, associados a disputas de poder externas à comunidade escolar, mas que influenciam fortemente o que acontece neste espaço. Destacamos nesse sentido os objetivos de enaltecer lugares da cidade do Rio de 
Janeiro e as Olimpíadas, evento esportivo que a prefeitura produtora dos Cadernos estava organizando. A presença frequente do gênero discursivo informativo com questões sociais nos mostra como na disciplina escolar Ciências as tradições curriculares acadêmicas se misturam a outras tradições, que estão marcadas neste gênero, isto é, a finalidades pedagógicas e utilitárias, como discute Goodson (1995, 1997 e 2001). Lopes (2007) realizou um estudo sócio histórico da trajetória curricular da disciplina escolar Ciências no Colégio de Aplicação da UFRJ (19691998) e defende que tradições acadêmicas, utilitárias e pedagógicas foram mescladas na constituição do ensino de Ciências nesta instituição, com predomínio da tradição acadêmica ao longo do tempo. Percebemos a mistura dessas tradições também nos materiais investigados. Percebemos que é no diálogo com estes textos e com as diferentes finalidades curriculares do ensino de Ciências que processos de leitura e de escrita acontecem nas salas de aula.

Em relação aos enfoques curriculares discutidos por Gomes (2008), os textos deste gênero se articulam aos enfoques da história natural e da ecologia, especialmente no que se refere aos movimentos ambientais e à educação ambiental, ao enfoque organizador do currículo anatomia, fisiologia e saúde humanas e ao enfoque vida cotidiana.

Nas páginas dos Cadernos exemplificadas acima, vemos também a presença de textos de outros gêneros discursivos analisados mais especificamente, além das fotografias e ilustrações, já comentadas. Dentre estes, aparecem nessas páginas os gêneros tabela, notícias de jornal e gráficos, expostos a seguir (FIGURA 12): 


\begin{tabular}{|c|c|}
\hline $\begin{array}{ll}\text { Aumento } & \text { da } \\
\text { temperatura }\end{array}$ & ALGUMAS CONSEQUENCIAS \\
\hline $\begin{array}{l}1 \text { 1'C (lê-se: "1 grau } \\
\text { Celsius") }\end{array}$ & $\begin{array}{l}\text { Encolhimento das geleiras; maior reproduçăo de insetos; morte } \\
\text { da maioria dos recifes de coral. }\end{array}$ \\
\hline $\begin{array}{l}2 \text { "C (lê-se: "2 graus } \\
\text { Celsius") }\end{array}$ & $\begin{array}{l}\text { Mais enchentes nas regiobes costeiras; espécies ameacadas de } \\
\text { extinçdo, como os ursos-polares do Artico. }\end{array}$ \\
\hline $\begin{array}{l}3^{\circ} \mathrm{C} \text { (lé-se: " } 3 \text { graus } \\
\text { Celsius") }\end{array}$ & Secas e falta de água afetariam 4 bilhões de pessoas. \\
\hline $\begin{array}{l}4^{* c} \text { (lê-se: " } 4 \text { graus } \\
\text { Celsius") }\end{array}$ & Produtos agricolas dirninuiriam em até $35 \%$. \\
\hline $\begin{array}{l}5^{\circ} \mathrm{C}(1 \hat{0}-s e: " 5 \text { graus } \\
\text { Celsius") }\end{array}$ & $\begin{array}{l}\text { Provável desaparecimento de grandes geleiras; ecossistemas } \\
\text { marinhos prejudicados; aumento do nivel dos oceanos em } 18 \text { a } \\
58 \mathrm{~cm} \text {, desaparecendo algumas ilhas e cidades costeiras. }\end{array}$ \\
\hline
\end{tabular}

\section{saiu no Jornall}

Em abril de 2016, quase todos os paises do mundo, incluindo o Brasil, firmaram um acordo, numa conferência conhecida como COP-21, que aconteceu na cidade de Paris (França). para reduzir as emissóes de carbono e conter o aquecimento global.

O objetivo de longo prazo do acordo

é manter o aquecimento global "muito abaixo de $2^{\circ} \mathrm{C}^{\prime \prime}$. Esse é o ponto a partir do qual cientistas afirmam que do qual cientistas afrmam que a planeta estaria condenado a um futuro como elevacaso do nivel do mar, eventos como elovacao do nivel do mar, eventos climáticos extremos (como secas. tempestades e enchentes) e faita de água e alimentos.

Glossario:

FONTE: Adaptado da BeC Brasil

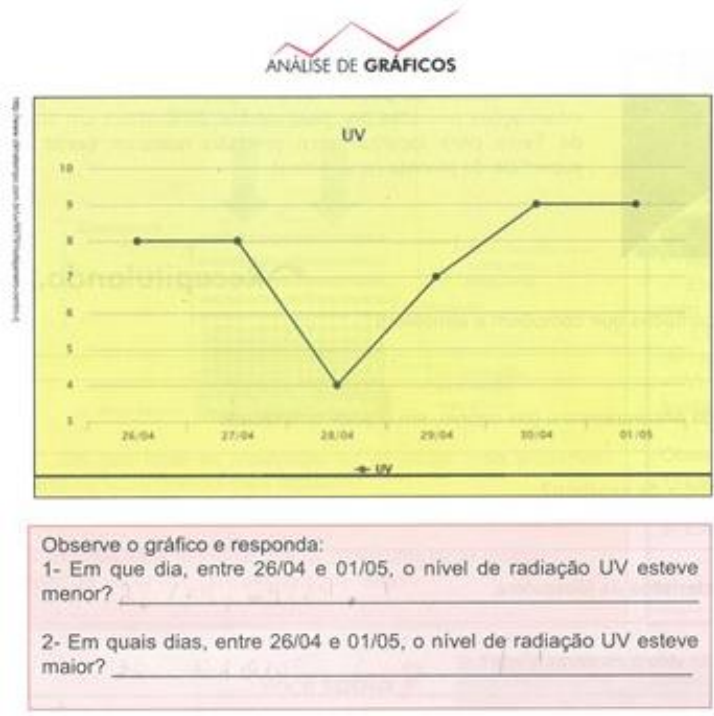

FIGURA 12: Exemplos de gêneros discursivos tabela, notícias de jornal e gráfico dos Cadernos Pedagógicos de Ciências do sexto ano do ensino fundamental - $3^{\circ}$ bimestre/ 2016 - da rede Municipal de Educação do Rio de Janeiro.

Embora presentes em menor quantidade nos Cadernos, importantes atividades de leitura e escrita ocorreram nas aulas observadas a partir destes gêneros. Tais atividades incluíram também os gêneros mapa, história da ciência, exercícios escritos de síntese e propostas de experimentação escolar. Todos esses gêneros refletiram as diferentes tradições curriculares e finalidades do ensino de Ciências que se mesclam nos textos. Percebemos isso, por exemplo, na tabela da Figura 12, que discute as consequências do aumento da temperatura terrestre. Há articulação com finalidades acadêmicas, como sugerem os termos reprodução de insetos e prejuízo aos ecossistemas marinhos e outras pedagógicas e utilitárias, de descrição do mundo para as crianças, ao mencionar enchentes, produção agrícola, desaparecimento de cidades, entre outros. No gráfico também podemos pensar na abordagem dos raios ultravioletas como um conteúdo que vem das ciências de referência, mas a aprendizagem de leitura do gráfico (como aparece nas perguntas sobre o gráfico) já se associa mais a finalidades pedagógicas e utilitárias. A 
contextualização com a inclusão de questões sociais, que aparece nas notícias de jornal, também parece se articular mais a tradições pedagógicas e utilitárias, relacionadas ao objetivo de trazer outros aspectos culturais (não científicos) para o ensino de Ciências. Em relação a reflexões sobre a linguagem, defendemos que esses gêneros discursivos se tratam de gêneros secundários do discurso, visto que se articulam a gêneros complexos como o científico e jornalístico e formas diferentes de organizar as informações, como mapas e tabelas.

Estes gêneros discursivos nos remetem à discussão sobre letramento multimodal, isto é, a capacidade de produzir e atuar em diferentes práticas sociais com textos multimodais, cujos significados se realizam por mais de um código semiótico, como imagens, texto escrito, etc. Autores que estudam multimodalidade textual defendem que todo texto é por definição multimodal, visto que são sempre formados por mais de um modo de representação, mesmo que em um texto oral esses modos sejam apenas as palavras e a entonação, ou as palavras e os silêncios, ou as palavras e os gestos; e em um texto escrito apenas as palavras e a tipografia. Toda ação social é multimodal e por isso todo gênero é também multimodal (DIONÍSIO, 2008). No entanto, Dionísio (2008) coloca que há um grau de variação na manifestação da multimodalidade, de forma que alguns textos são mais multimodais que outros, ou seja, integram mais tipos diferenciados de informação que outros, dependendo da instância a que o texto se destina e do meio físico que o comporta. Pesquisadores que estudam multimodalidade destacam a importância de trabalhos com textos multimodais na escola atualmente, considerando que as novas formas de comunicação e tecnologia exigem que sejamos capazes de ler e escrever em múltiplas fontes de linguagem, nas quais imagens e palavras estão cada vez mais integradas. Dionísio (2008), por exemplo, ressalta "a diversidade de arranjos nãopadrões que a escrita vem apresentando na mídia em função do desenvolvimento tecnológico" (DIONÍSIO, 2008 pg. 132). Nesse mesmo contexto, Santos (2006) discute que a multimodalidade compõe os meios linguísticos contemporaneamente, de forma que para ler hoje qualquer mensagem escrita, é fundamental ser capaz de compreender também outros elementos representacionais que coexistem no texto.

Analisando as páginas dos Cadernos Pedagógicos que apresentamos anteriormente, percebemos que são formadas por textos de vários gêneros discursivos que interagem entre si. Nesse sentido, se expressam como uma configuração multimodal. Assim, a princípio podemos pensar nas aulas de Ciências 
como espaços para ampliação do acesso a multimodalidade, ao refletirmos sobre os vários gêneros e a interação entre eles que ali acontece. Por outro lado, Dionísio (2008) chama atenção para o fato de que para desenvolver processos de ensinoaprendizagem de leitura de textos multimodais não basta colocar textos e imagens juntos no mesmo material, é preciso refletir sobre princípios organizativos de textos multimodais e sobre os processos complexos envolvidos na leitura de um material com múltiplas informações. Uma das professoras investigadas, em um dia de observação na sala dos professores, falou que considera a apostila "muito confusa". Parece que a lógica de organização dos textos, a forma como são escolhidos e colocados em conjunto não fica claro para as professoras, o que pode dificultar processos de ensino-aprendizagem de leitura e escrita, pois é necessário que:

(...) professores e alunos estejam plenamente conscientes da existência de tais aspectos: o que eles são, para que eles são usados, que recursos empregam, como eles podem ser integrados um ao outro, como eles são tipicamente formatados, quais seus valores e limitações. (LEMKE, 2000 apud DIONÍSIO, 2008, pg. 140).

Buscando construir um diálogo com Bakhtin, podemos pensar na importância do acesso a diferentes gêneros discursivos para ampliação das possibilidades de interação social dos estudantes. Se os gêneros são ações sociais que manifestamos no uso da linguagem, nossas possibilidades de interação sociocultural dependerão do domínio de novos gêneros. O autor coloca que:

\footnotetext{
Quanto mais dominamos os gêneros, maior é a desenvoltura com que os empregamos e mais plena e nitidamente descobrimos neles a nossa individualidade (onde isso é possível e necessário), refletimos de modo mais flexível e sutil a situação singular da comunicação - em suma, tanto mais plena é a forma com que realizamos o nosso livre projeto de discurso (BAKHTIN, 2016, pg. 41).
}

Daí a importância de olhar para a escola como um espaço de letramentos. Letramentos nos diferentes tipos e possibilidades de ação social através de enunciações, que acontecem como gêneros discursivos. Nesse sentido, o ensino de Ciências pode ser um espaço pedagógico de enorme importância também por permitir processos de ensino-aprendizagem de variados gêneros discursivos, variados letramentos.

Em relação a esse aspecto, é importante problematizar algumas questões. A principal delas diz respeito à descontextualização dos textos dos Cadernos. Apesar 
do material possuir textos de gêneros distintos, o que parece ser importante para ampliar o acesso dos alunos a tipos diferentes de formas de enunciados, cabe perguntar até que ponto esses textos se aprofundam no conhecimento que buscam construir. Defendemos que para construção de sentidos na leitura de um texto é importante que se estabeleçam relações com a própria realidade social e a partir dela se construa a possibilidade de ampliação simbólica dessa realidade. Baseadas em Koch (2015), em uma perspectiva bakhtiniana, acreditamos que os sentidos na leitura se constroem a partir das interações que o leitor traz para o texto, que surgem de suas vivências e das atividades sociais que realiza. Assim, com a homogeneização do currículo para toda rede municipal, os vínculos com realidades tão diversas são mais difíceis de serem estabelecidos, dificultando os processos de ensino-aprendizagem de leitura. Nesse sentido, parece-nos importante que sejam criados mais espaços na prática pedagógica para o diálogo com as dificuldades dos estudantes e a realidade da escola e de sua comunidade, com a ampliação da autonomia das professoras para que construam esses processos.

Outra problematização importante diz respeito à superficialidade dos textos dos Cadernos, que se reflete no tamanho dos mesmos, sempre curtos, com poucas linhas, de forma que não aprofundam discussões sobre os conhecimentos que desenvolvem. Nenhum dos textos analisados ocupou mais que um quadro de uma única página dos Cadernos. Soares (1998) destaca que é importante continuarmos refletindo sobre os textos escritos na escola, especialmente em uma época de supervalorização de imagens. Para a autora, no contexto brasileiro, no qual a leitura tem pouca presença cotidiana na vida dos estudantes, cabe à escola criar oportunidades de leitura de textos escritos para a construção de conhecimento. Nesse sentido, vale pensarmos se as aulas de Ciências têm contribuído para o acesso a textos escritos mais longos, que exigem um maior investimento no processamento da linguagem escrita. As professoras investigadas criticaram os Cadernos (que chamam de apostila), especialmente em relação ao tamanho dos textos e seus conteúdos, como vemos nas falas a seguir:

\footnotetext{
"Eles têm uma apostila que pra mim não funciona e eu ... acho que fica faltando informação". (Fala de uma das professoras investigadas)

"Então assim os textos da apostila... têm notícias de jornal, que relacionam com o meio e isso é legal, com o que a gente vivencia no
} 
dia a dia. Mas assim, de conteúdo eu acho que fica faltando demais". (Fala de uma das professoras investigadas).

"Eu acho que os textos da apostila são textos muito curtos, então tem perguntas muito óbvias". (Fala de uma das professoras investigadas).

Os alunos também colocaram críticas aos Cadernos em relação aos textos e possibilidades de aprendizagens a partir deles e comentaram também sobre erros encontrados no material.

"Eu gosto mais do caderno...porque...sei lá... a gente aprende mais coisa do que na apostila". (Fala de um estudante de uma das escolas investigadas).

"É porque na apostila ela só dá o resumo disso tudo. Só dá o resumo do que acontece. A gente já quer saber o que vai acontecer, o que aconteceu, o que é isso..." (Fala de um estudante de uma das escolas investigadas).

"A1: As apostilas têm muitos erros. (...) Explicando coisa errada.

A2: Falando coisa errada.

A1: (...) Ela manda a gente riscar... essas coisas...(...)

A3: Hoje já teve três erros". (Fala de um estudante de uma das escolas investigadas).

"Assim na apostila a gente só responde as coisas. As perguntas que tão lá e pronto". (Fala de um estudante de uma das escolas investigadas).

Destacamos a última fala dos estudantes e a última fala das professoras, que se referem às possibilidades de escrita a partir dos Cadernos. A professora coloca que "tem perguntas muito óbvias" e os alunos que "na apostila a gente só responde as coisas". Na seção a seguir analisamos as propostas de produção textual que aparecem nos Cadernos. 


\subsubsection{2.}

\section{Propostas para escrita nos Cadernos Pedagógicos de Ciências}

Os Cadernos Pedagógicos possuem textos de variados gêneros discursivos e em alguns casos estes vêm acompanhados de perguntas sobre esses textos. Abaixo trazemos novamente alguns exemplos para analisarmos as perguntas associadas aos textos (FIGURA 13).

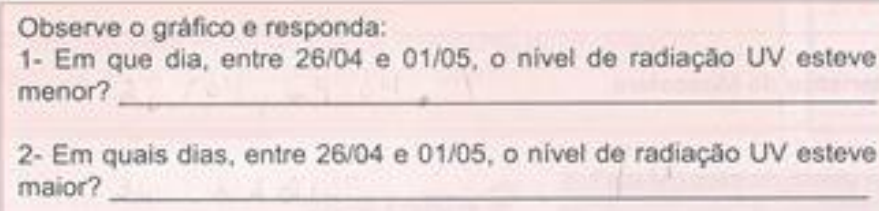

FIGURA 13: Perguntas associadas a um gráfico exposto na página 30 do Caderno Pedagógico de Ciências do sexto ano do ensino fundamental - $3^{\circ}$ bimestre/ 2016 - da rede Municipal de Educação do Rio de Janeiro.

As questões apresentadas aparecem articuladas a um gráfico sobre os níveis de radiação ultravioleta na cidade do Rio de Janeiro de 26/04 a 01/05. São perguntas que estimulam que os estudantes leiam o gráfico e busquem informações no mesmo, atividade bastante complexa, como coloca Dionísio (2008) em suas reflexões sobre textos multimodais. Mas as respostas escritas exigidas são simples, apenas colocar o dia, sem criar outras relações possíveis e incentivar a produção de textos mais abertos. A seguir outro exemplo de perguntas escritas do Caderno Pedagógico (FIGURA 14): 


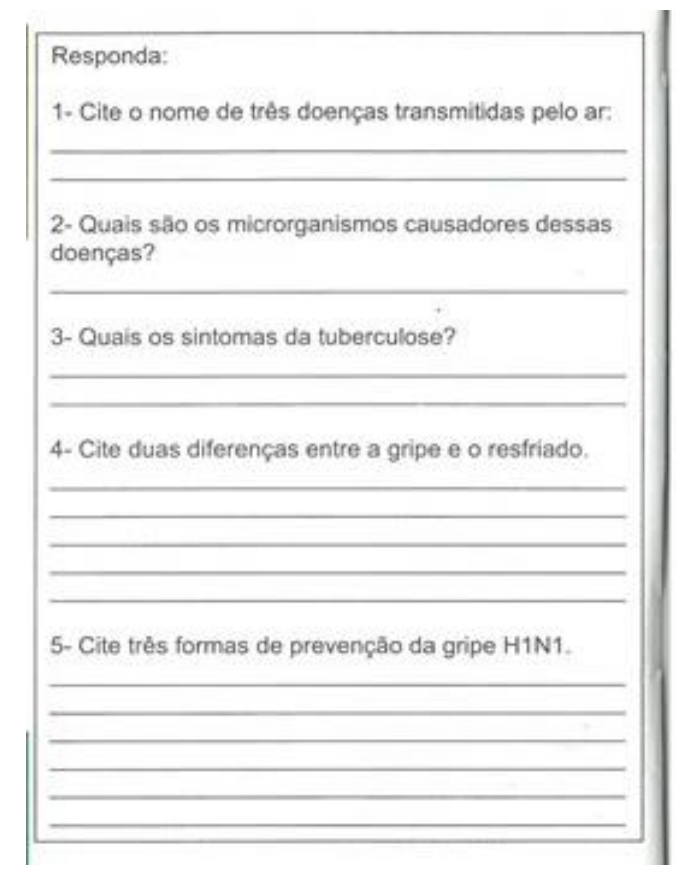

FIGURA 14: Perguntas da seção "Recapitulando..." da página 25 do Caderno Pedagógico de Ciências do sexto ano do ensino fundamental - $3^{\circ}$ bimestre/ 2016 - da rede Municipal de Educação do Rio de Janeiro.

Estas perguntas compõem o gênero que denominamos de propostas de exercícios de síntese (escritos ou de marcação), pensando na função que exercem. Também trata-se de um gênero que compreendemos como um gênero discursivo secundário, que se articula às diferentes finalidades da disciplina escolar Ciências. Percebemos isso pelos tipos de perguntas, que parecem associar aspectos acadêmicos relacionados a causas e características de doenças com tradições mais utilitárias, associadas a questões de saúde, como a prevenção de doenças. Analisando as perguntas em relação às respostas escritas demandadas, percebemos que exigem respostas objetivas e diretas, que devem simplesmente ser extraídas de textos anteriores, sem criar possibilidades para que os estudantes pensem em outras articulações e tragam novas informações para o diálogo escrito. Isso acontece também nas perguntas sobre textos do gênero discursivo científico escolar, como vemos no próximo exemplo (FIGURA 15): 


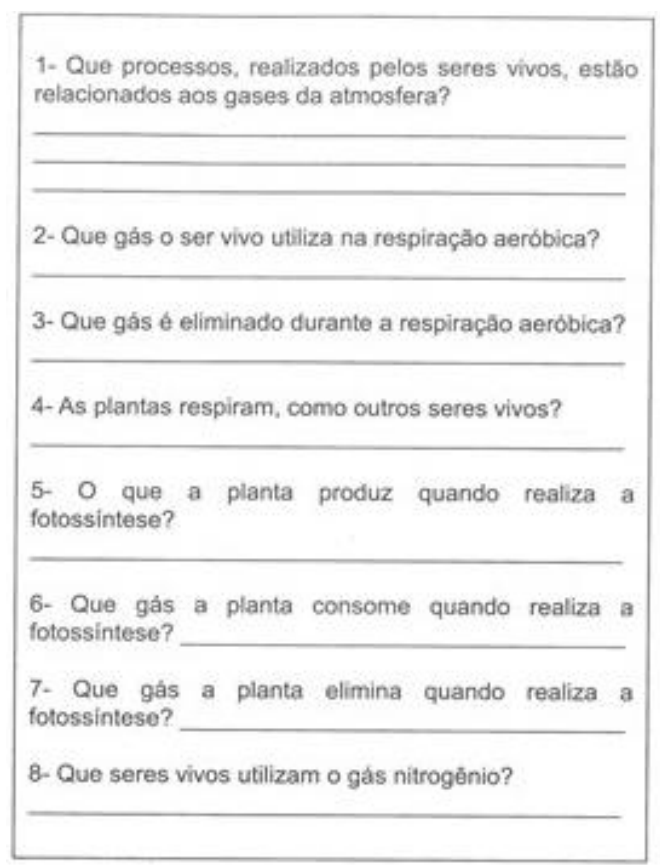

FIGURA 15: Perguntas associadas a um texto exposto na página 20 do Caderno Pedagógico de Ciências do sexto ano do ensino fundamental - $3^{\circ}$ bimestre/ 2016 - da rede Municipal de Educação do Rio de Janeiro.

As perguntas estavam associadas a um texto do gênero discursivo científico com o título "O ar e os seres vivos", comentado anteriormente. Os tipos de perguntas exigem apenas a retirada direta de informações do texto, muitas vezes de apenas uma palavra. As perguntas que exigiam respostas escritas dos Cadernos e foram utilizadas nas aulas observadas funcionam dessa maneira, são objetivas, diretas e fechadas. Como discutido anteriormente, Cassiani-Souza et al (2012) destacam que têm observado que o esperado em relação à escrita nas disciplinas escolares científicas é apenas a extração e repetição de informações. Isso aparece claramente nas perguntas que os Cadernos trazem, como percebemos nos exemplos anteriores (FIGURAS 13, 14 e 15). Vemos também o estímulo ao que Giraldi e Cassiani (2009) denominam "Efeito papagaio", no qual os alunos apenas repetem o sentido estabelecido pela professora (ou pela Secretaria de Educação, nesse caso). Ainda sobre essa questão, Pinheiro e Galieta (2016) propõem uma discussão sobre a relação entre autoria e letramento científico e investigam produções textuais de estudantes do ensino fundamental. As autoras perceberam que o discurso pedagógico autoritário, que estimula a paráfrase, se expressa na memória discursiva das crianças em sua relação com a escola e influencia na tendência a repetições 
mnemônicas e formais na escrita. Porém, notaram a possibilidade de autoria, em repetições polissêmicas, quando as atividades foram realizadas com discursos pedagógicos lúdicos, mais flexíveis. Almeida et al (2008), no desenvolvimento de propostas de leitura e de escrita envolvendo o tema fotossíntese, discutem a formação de autores no ensino de Ciências e colocam a importância de investir em demandas escritas diferenciadas, com gêneros variados (como cartas, diários, etc) e possibilidades de escrita mais livres. Os Cadernos Pedagógicos investigados na maioria das propostas de escrita, fazem o contrário disso.

Em diálogo com a teoria bakhtiniana, entendemos que, dependendo da forma como as demandas de escrita forem desenvolvidas na escola, será possível uma maior ou menor aparição do estilo individual do autor, permitindo maior ou menor autoria. Bakhtin discute que todo gênero discursivo expressa de alguma forma a individualidade, o estilo individual, visto que todo enunciado é individual. Porém, alguns gêneros permitem que o reflexo da individualidade de quem fala ou escreve apareça mais do que outros. Nesse sentido, cabe a reflexão se nas aulas de Ciências temos permitido que a individualidade dos alunos apareça nas produções escritas, de forma que possam aprender a desenvolver textos mais autorais.

Como colocado anteriormente, resgatamos a pesquisa de Dias (2017) sobre a relação entre autoria e pesquisa escolar, para refletir sobre o conceito de autoria. O pesquisador coloca que autoria é um conceito bastante difuso, que abre espaço para diferentes significações. Ao pensar sobre como a autoria pode aparecer na pesquisa escolar, enaltece a importância de os estudantes estabelecerem diálogos com as fontes consultadas para, a partir destas vozes, se posicionarem no mundo de forma individualizada. $\mathrm{O}$ autor seria aquele que "de certa forma, molda o objeto trabalhado, dando a ele suas nuances, suas formas" (DIAS, 2017, pg. 43). Apoiando-se na perspectiva bakhtiniana, destaca como esse molde é construído a partir do diálogo com o outro, isto é, depende da alteridade, pois trata-se de construir posições individuais a partir da cadeia discursiva polifônica que está no outro.

Como discutimos, o conceito de autoria é central para Bakhtin. Uma discussão mais profunda desse conceito está além do escopo da pesquisa, mas buscamos alguns elementos importantes para pensar as possibilidades de que o espaço das aulas de Ciências possa contribuir também na formação autoral, como parte imprescindível do ensino-aprendizagem da escrita. Nesse sentido, 
recuperamos as reflexões de Sobral (2012, pg.5) que diz que "A posição do autor com respeito ao conteúdo de seu enunciado é ativa, mas não o coloca acima de todas as influências que incidem sobre seu agir em seu ambiente sócio-histórico". Assim, o autor tem um estilo e particularidade, mas essa é influenciada e determinada pelas condições sociais, históricas e culturais de produção: “ $O$ estilo, assim, também é interativo, também é dialógico, vem da relação entre o autor e o grupo social de que faz parte, em seu representante autorizado, ou típico, definese a partir da imagem social do ouvinte, que também é um fator intrínseco vital da obra" (SOBRAL, 2012, pg. 5). Essas colocações trazem duas ideias importantes. Primeiro, a do valor do diálogo no desenvolvimento da autoria, como Dias (2017) também coloca; depois, a da importância das relações que o autor estabelece com seu grupo social para se formar autor. Dias (2017) pensa sobre essa questão ao trazer contribuições de Orlandi (2006 apud DIAS, 2017) para pensar autoria na escola. A partir desta autora, ele defende que a instituição escolar, embora não seja suficiente, é um espaço necessário para formar autores, em relação com o que está fora dela.

\footnotetext{
(...) para ser autor, sim: a escola é necessária, embora não suficiente, uma vez que a relação com o fora da escola também constitui a experiência da autoria. De toda forma, a escola, enquanto lugar de reflexão, é um lugar fundamental para a elaboração dessa experiência, a da autoria, na relação com a linguagem. (ORLANDI, 2006, p. 82 apud DIAS, pg. 46).
}

Nesse sentido, cabe retomarmos a discussão sobre como a estrutura curricular tão controlada, associada a avaliações externas, pode dificultar o trabalho de exploração da linguagem escrita nas aulas de Ciências. A relação com o contexto de vida dos alunos, com o que está fora da escola, seria central para o desenvolvimento da autoria. É na vivência das relações sociais que estabeleço que posso buscar a expressão da minha individualidade. Assim, a consideração das experiências de vida dos estudantes seria fundamental para a formação de uma escrita mais autoral. Mas como considerar essas vivências deixando um espaço cada vez menor para que as atividades pedagógicas sejam desenvolvidas de acordo com a realidade na qual a escola está inserida? Em uma estrutura que busca a homogeneidade e a normatização, como trazer as condições sociais de cada lugar para os processos de escrita? Observamos que as professoras tentam romper a normatização através dos diálogos que estabelecem com os alunos nas salas de aula, 
o que acontece no desenvolvimento das atividades pedagógicas com o uso dos Cadernos. Assim, apesar dos exercícios e dos textos não considerarem os contextos dos alunos (visto que são iguais para todas as escolas da rede), as professoras de Ciências tentam trazê-los e assim potencializam a possibilidade de escrita e de leitura nas aulas. Na nossa investigação percebemos que as diferentes atividades pedagógicas realizadas com o uso dos Cadernos permitiram a mobilização de variadas estratégias e conhecimentos relacionados à leitura, principalmente, e alguns relativos à escrita. Assim, processos de ensino-aprendizagem relacionados à leitura e/ou à escrita foram possíveis devido à forma como as professoras utilizam estes materiais, que extrapolam muitas vezes o que é ali demandado, ampliando as possibilidades de articulação com a linguagem escrita. A seguir apresentamos alguns trechos transcritos de atividades utilizando estes materiais e discutimos em que medida e de que forma processos de ensino-aprendizagem de leitura e/ou de escrita ocorreram.

\subsubsection{2. Utilização dos Cadernos Pedagógicos de Ciências}

Atividades pedagógicas articuladas à linguagem escrita realizadas com os Cadernos Pedagógicos incluíram: leitura em voz alta pela professora; leitura em voz alta pelos alunos; leitura individual silenciosa pelos alunos; elaboração de respostas escritas de exercícios em diálogo entre a professora e os estudantes; elaboração de respostas escritas individuais pelos estudantes; correção de exercícios escritos pela professora em diálogo com toda turma; e correção de exercícios pela professora de cada aluno individualmente. Além disso, ocorreram aulas práticas com experimentação propostas pelos Cadernos, analisadas posteriormente (seção 4.3.2). Nesta seção, apresentamos transcrições do diário de campo e de audiogravações de momentos das aulas nos quais atividades de leitura e/ou de escrita foram realizadas com o uso dos Cadernos Pedagógicos. A partir delas, discutiremos questões específicas envolvidas no ensino-aprendizagem de leitura e/ou escrita, especialmente através de contribuições da linguística sociointeracionista (KOCH e ELIAS, 2015 e 2017).

Em nossa investigação, trabalhamos com a ideia de texto como um lugar de interação, no qual os sujeitos, sempre sociais, se constituem e são constituídos. O 
texto, como materialização do discurso, faz parte da cadeia discursiva na qual o sujeito realiza suas atividades sociais e assim se constrói e constrói o mundo. Nesse sentido, a compreensão de um texto vai depender da mobilização do contexto sociocognitivo no qual se movem os atores sociais. É nesse contexto que os sujeitos desenvolvem suas atividades sociais e a partir dele constroem objetos de discurso e propostas de sentido para o que leem e/ou escrevem. Leitor e autor são estrategistas na interação social pela linguagem que ocorre através dos textos, realizando diferentes e complexas estratégias sócio-cognitivas para serem capazes de compreender e/ou produzir um texto.

Refletindo mais especificamente sobre a leitura, defendemos que para realização desta atividade, o leitor precisa mobilizar variadas estratégias linguísticas e cognitivo-discursivas para dar sentido ao texto. Na mobilização destas estratégias, o leitor cria antecipações e hipóteses sobre o que está lendo, valida ou não as hipóteses que vai levantando ao longo da leitura, preenche lacunas que o texto apresenta e assim, ativamente, participa da construção de um sentido para o texto. Tudo isso dependerá dos conhecimentos que o leitor carrega e traz para o diálogo com o texto que interage, conhecimentos da língua, da organização textual e do mundo que o cerca. Assim, entendemos a leitura como "uma atividade interativa altamente complexa de produção de sentidos" (Koch e Elias, 2015, pg. 11), que dependerá sempre das experiências e conhecimentos que o leitor carrega, como discutimos anteriormente. O leitor parte de pistas que o texto carrega para, em articulação com seus próprios saberes, construir um sentido para o texto que seja compatível com a proposta de seu autor. Ao fazer isso, assume uma atitude responsiva ativa, concordando ou não com as ideias do autor, completando-as, adaptando-as, criticando-as, etc., já que "toda compreensão plena real é ativamente responsiva e não é senão uma fase inicial preparatória da resposta (seja qual for a forma em que ela se dê)" (BAKHTIN, 2016, pg. 25).

A seguir, apresentamos um evento no qual ocorreu uma atividade de leitura de um texto do Caderno Pedagógico do $3^{\circ}$ bimestre (COORDENADORIA DE EDUCAÇÃO DO RIO DE JANEIRO, 2016 a, pg. 23). A professora estava lendo em voz alta e os alunos acompanhavam a leitura nos próprios Cadernos. É um texto do gênero discursivo que denominamos informativo com questões sociais. Pertence ao enfoque curricular anatomia, fisiologia e saúde humanas e aborda formas de prevenção de doenças transmitidas pelo ar, se associando a finalidades 
utilitárias do ensino de Ciências. Descrevemos esse texto na seção anterior (FIGURA 9). No trecho transcrito abaixo, observamos que a professora iniciou a discussão com os estudantes comentando o assunto do tex to e propondo um diálogo sobre o título do mesmo:

“- A professora segue para a página 23. Fala sobre o que será discutido a partir de agora (doenças).

Professora: Aí vai falar agora sobre uma coisa que vocês adoram nas aulas de Ciências que é falar de doenças, né? Falar de doenças é uma coisa que... (...)

Professora lê o título: Doenças transmitidas pelo ar. Comenta: Me falem aí uma doença que vocês acham que pode ser transmitida pelo ar.

- Alunos respondem algumas. Veem nomes na apostila. (Caxumba, H1N1, Gripe, resfriado).

Estudante A: H1N1.

Professora: H1N1 é a mais famosa.

Estudante B: Caxumba

Professora: Caxumba.

Estudante C: Febre.

Professora: A gripe. Febre é o sintoma. Que mais?

(...)" (Notas do diário de campo e transcrição de audiogravação).

Para que a atividade de leitura seja realizada e os sentidos possam ser produzidos, diversas estratégias sócio-cognitivas precisam ser mobilizadas pelos estudantes. De acordo com Koch e Elias (2015), o processamento textual é estratégico, o que significa que diante de um texto os leitores realizam simultaneamente vários passos interpretativos finalisticamente orientados, efetivos, flexíveis e extremamente rápidos, mesmo que nem se deem conta disso. As estratégias que os leitores utilizam no processamento textual acontecem com o acesso a três grandes sistemas de conhecimento: i) o conhecimento linguístico: conhecimento gramatical e lexical; ii) conhecimento de mundo ou enciclopédico: conhecimentos gerais sobre o mundo e relativos a vivências pessoais e eventos situados espaço e temporalmente; iii) conhecimento interacional: conhecimentos sobre as formas de interação por meio da linguagem, como a noção dos objetivos do autor, adequação do gênero discursivo à situação comunicativa, quantidade de informação e variante linguística necessária, entre outros. Em nossas observações percebemos que a forma como a professora constrói a mediação entre o texto e os 
alunos, colabora para que acessem diferentes estratégias para leitura, mobilizando e ampliando seus diferentes sistemas de conhecimentos.

Essas estratégias envolvem antecipações e hipóteses sobre o texto, que vão sendo testadas ao longo da leitura. A atividade de leitores ativos sempre começa com antecipações e hipóteses do que esperam do texto, antes mesmo de começar a lê-los propriamente. Para isso, se respaldam em conhecimentos que tem arquivados sobre a língua, sobre as coisas do mundo, sobre outros textos, sobre gêneros discursivos, entre outros. Os tais sistemas de conhecimentos. Nas salas de aula de Ciências, os estudantes provavelmente fazem antecipações sobre o que esperam de um texto da escola, mais especificamente do Caderno Pedagógico e de aulas de Ciências, devem esperar, por exemplo, palavras difíceis, como colocam na entrevista "Cada palavra tão grande... Cada nome esquisito”. Um dos elementos que participam da antecipação e elaboração inicial de hipóteses sobre o que será lido é o título, que funciona como um "elemento constitutivo do texto, cuja função é, geralmente, chamar a atenção do leitor e orientá-lo na produção de sentido" (KOCH e ELIAS, 2015, pg. 13). No trecho transcrito vemos que a professora chama atenção para o título e discute o tema que o texto irá abordar. Dessa forma, ajuda os estudantes a fazerem antecipações e começarem a pensar sobre o que esperam daquele texto. Os estudantes respondem à proposta da professora e trazem suas vozes colocando doenças que conhecem e que veem no Caderno. Na construção desse diálogo, a professora induz os estudantes a acessarem conhecimentos de mundo que possuem sobre o objeto do texto que será lido a seguir, relacionando-o com suas experiências sociais. Os ajuda também a mobilizarem o sistema de conhecimento linguístico associado ao tema, como os nomes das doenças. Depois de ajudá-los a pensar e trazerem seus conhecimentos sobre doenças transmitidas pelo ar, a professora começa a ler o texto em si.

“Professora: (...). Então vamos ver o que eles estão falando aí das doenças.

Professora lê em voz alta o primeiro parágrafo da página 23 sobre prevenção das doenças: Com a chegada do frio, aumentam os casos de resfriados e gripes e outras doenças transmitidas pelo ar. Por isso, é necessário conhecê-las e multiplicar, em nossas comunidades, as informações de prevenção a essas doenças.

- Depois a Professora vai comentando as imagens e lendo os textos sobre formas de prevenção, tentando construir um raciocínio com os alunos.

Professora: Primeiro, fazer uma boa alimentação. (...)" (Notas do diário de campo e transcrição de audiogravação) 
Entendemos que nesse momento de interação com o texto, estudantes e professora estão testando hipóteses que formularam sobre o que o texto trataria. Depois de ler a primeira parte do texto, com os alunos a acompanhando, a professora começou a analisar as imagens e traz o termo "Primeiro". Assim, ajuda os estudantes a criarem antecipações de que depois daquela, outras imagens e textos tratarão do tema que estão abordando. Essa é uma forma da professora ir ajudandoos a criar hipóteses e seguirem testando suas hipóteses ao longo da leitura. Ela segue então a leitura das imagens e do texto escrito associado, dialogando com os estudantes em interação com a linguagem escrita e imagética do Caderno.

"Professora lê: Evitar lugares fechados com aglomeração de pessoas. Pergunta: Por que você evitar lugar fechado, vai evitar de pegar uma gripe? Comenta: Imagine a gente nessa sala aqui, fechando todos os vidros. Tem aqui metade da turma espirrando o tempo todo. Qual é a chance de outra pessoa sadia pegar?

Estudante B: Muito grande.

Professora: Muito grande. Então o correto é que a gente esteja em ambientes que estejam arejados. Janelas e portas abertas sempre. Pegando esse gancho, por que que ele falou então que no frio a gente tem maiores chances de pegar um resfriado ou uma gripe?

Estudante C: Porque pega ventania, chuva...

Professora: A ventania, a chuva... E o que que tem a ver com o que a gente tá conversando aqui, essa história de aglomeração? Quando tá frio, as pessoas dentro do ônibus, tá frio e tá chuviscando. Caem aquelas gotinhas bem pequenininhas. O que o pessoal faz no ônibus? Deixam tudo aberto?

Estudantes: Não.

Professora: A primeira coisa que fazem é fechar. (...) Imagina uma pessoa que está resfriada ali, começa a espirrar, tossir, sei lá o que. O que vai acontecer com todo mundo que está dentro do ônibus? A grande maioria? Tem grandes chances de que?

Estudante D: De ser contaminado.

Professora: De ser contaminado, de pegar uma gripe, um resfriado.

Professora: Então, no frio, a tendência das pessoas é ficar em lugares que estejam mais aquecidos, ou seja, fechar os ambientes, inclusive no ônibus, que eu acho que é o pior de todos. E aí as pessoas acabam ficando doentes, porque elas transmitem essas doenças pelo ar.

Estudante E: O que que você faz quando está na van e alguém tá tossindo ou espirrando?

Professora: O que que eu faço? Não posso mandar a pessoa parar de tossir ou espirrar, né? E a janela não pode abrir?

Estudante E: Não...

Professora: Então você fica lá esperando talvez pegar uma gripe ou você sai do ônibus ou da van. Expulsar a pessoa doente é que não dá! 
- Alunos acompanham e participam da discussão. Professora continua lendo formas de prevenção que estão descritas na apostila e conversando sobre elas com os alunos. Faz intervenções em algumas delas.

Professora: Mantenha os ambientes arejados. Comenta: A gente acabou de falar sobre isso.

Professora continua lendo: Evite colocar a mão suja nos olhos, boca e nariz. Manter limpas superfícies como mesas, por exemplo. Lave as mãos com frequência e use álcool gel.

(...)

Professora: (...). Quando a gente espirra, quando a gente até mesmo passa a mão no rosto, que a gente tem aquela secreção, característica de doenças como a gripe, a gente acaba transmitindo isso pelo contato dessa secreção na nossa mão. Por exemplo, se eu estou aqui resfriada, vou espirrar na minha mão, aí eu dou um abraço no Lucas, coloco a mão no rosto dele, eu estou transmitindo essa doença pro Lucas. Então é importante manter as mãos sempre limpas. Quando a gente for espirrar ou tossir, não sei se vocês já ouviram isso, a gente não tem que colocar a mão no rosto.

- Aluno faz o gesto de colocar a boca entre braço e antebraço.

Professora: Isso. A gente tem que botar a boca aqui nessa dobrinha entre o braço e o antebraço. Por que? Quando a gente cumprimenta, abraça ou encosta alguém a gente chega assim: Fala Lucas! (Professora faz gesto como se fosse cumprimentar usando o antebraço).

- Alunos riem e respondem: Não!

Professora: Não né? A gente costuma o que? Usar ...

Estudantes: as mãos.

Professora: As mãos. Para pegar objetos? Vou lá dou aquela espirrada básica, coço meu nariz, coloco a mão na caneta, boto aqui, aí o Lucas coloca a mão. Vou estar transmitindo para ele.

Estudante E: Vai estar sendo contaminado.

Professora: Exatamente, vai estar sendo contaminado. Então é importante que a gente tenha o hábito de usar o braço para isso e não as mãos.

Professora continua lendo: Evite contato direto com pessoas que estejam com doenças... Cubra a boca e o nariz ao tossir ou espirrar.

- Professora comenta sobre a imagem: e aparece o lencinho. Ela fala sobre lenços e toalhinhas que os alunos costumam levar pra escola. Fala que o correto é usar lenços descartáveis.

Professora: Gente, essa imagem do cara usando um lencinho é muito infeliz, tá? Por favor, aproveitando que eu vejo que vocês têm o hábito de trazer uma toalhinha para ficar esfregando o nariz, limpando o nariz seja lá o que for. Aquilo não é higiênico gente. Primeiro porque vocês colocam o seu paninho ou a toalhinha em cima da mesa que está cheia de bactérias (...). Aí você esfrega no seu rosto. Isso não é higiênico (...) O correto é usar lenço descartável. (...). Então parem com esse hábito de trazer esses paninhos. Eles não são higiênicos, nem um pouco. (...).

Professora lê última parte: Não compartilhe objetos de uso pessoal." (Notas do diário de campo e transcrição de audiogravação).

Neste trecho, percebemos que ao longo da leitura a professora traz as vozes dos alunos para o diálogo, mediando a interação entre o texto e os alunos. Como 
discutimos, é através desse diálogo entre a professora, os alunos e o texto, que eles vão construindo sentido para o que leem. A professora ajuda os estudantes a criarem uma relação entre o que o texto traz e seus conhecimentos e contextos sociais. Percebemos isso quando ela desenvolve um raciocínio imaginando um ônibus fechado em um dia frio (“Quando tá frio, as pessoas dentro do ônibus, tá frio e tá chuviscando. Caem aquelas gotinhas bem pequenininhas. $O$ que o pessoal faz no ônibus? Deixam tudo aberto?"), situação que os estudantes provavelmente já vivenciaram, o que confirmam ao responderem à pergunta e colocarem suas vozes no diálogo. Ou ainda quando um aluno a partir dessa situação criada pela professora imagina uma outra e a questiona, impondo sua participação no diálogo " $O$ que que você faz quando está na van e alguém tá tossindo ou espirrando?". A interação com o texto é também estimulada quando a professora conversa com os estudantes sobre como agir com o corpo quando espirrar ou tossir e um aluno faz o gesto que a professora considera adequado. A partir disso, ela realiza uma brincadeira que faz os alunos rirem e participarem do diálogo, quando cria um teatro cumprimentando um dos estudantes com o antebraço. Outro trecho que nos permite perceber essa mediação da interação está na relação que a professora cria entre o lencinho que aparece na ilustração do Caderno e a toalhinha que os alunos costumam levar para escola.

Assim, é através do diálogo que constitui a interação entre a professora, os autores do texto e os estudantes que a leitura acontece. É nesse diálogo, com o apoio das professoras, que as conexões entre os textos e as experiências, vivências e saberes dos estudantes vão sendo construídas. Na mediação, a professora faz com que os estudantes acessem e tragam sua bagagem sócio-cognitiva, que inclui conhecimentos sobre a língua e sobre as coisas do mundo, para interação com o texto.

Vemos que a professora vai lendo e discutindo, criando relações com situações cotidianas dos alunos, ativando o lugar social de onde os alunos leem. Assim, ativa os sistemas de conhecimentos dos alunos-leitores para que criem um sentido para o texto e dessa forma potencializam a possibilidade de leitura. Defendemos que essa ativação faz parte de processos de ensino-aprendizagem de leitura ao ajudarem os estudantes a produzirem sentidos, a partir dos conhecimentos que possuem. É ao atuarem na mobilização de estratégias sócio-cognitivas de 
leitura para ensinarem Ciências que as professoras acabam por produzir situações de ensino-aprendizagem de leitura com os alunos.

Outros trechos de observações mostram também a ativação de estratégias e conhecimentos para atividades de leitura com os estudantes. A seguir um momento de leitura de um texto do gênero discursivo científico escolar. O texto tratava sobre a troca de gases entre os seres vivos e a atmosfera, pertencendo ao enfoque curricular ecologia e a tradição acadêmica da disciplina escolar Ciências. Ele está na página 20 do Caderno Pedagógico de Ciências do $3^{\circ}$ bimestre de 2016 (COORDENADORIA DE EDUCAÇÃO DO RIO DE JANEIRO, 2016 a, pg. 20) (FIGURA 2). A seguir, vemos que a aula começa também com a professora propondo uma discussão a partir do título do texto:

\footnotetext{
“- A professora segue para página 20 da apostila. Discute com os estudantes o conteúdo da página 20. Como se explicasse o que está escrito no texto, antes mesmo de ler. Explica discutindo com eles. Conteúdo complexo sobre respiração e fotossíntese. Mesmo assim os alunos prestam atenção e participam. (Parecem interessados, mesmo em um assunto tão acadêmico).

Professora: Anotou? Pode ir para página 20.

Professora lê o título: $\mathrm{O}$ ar e os seres vivos.

Professora: Nós dependemos do ar. Concordam?

Estudante A: Concordo.

Estudantes: Concordamos

Estudante B: Sim!" (Notas do diário de campo e transcrição de audiogravação).
}

O título tem a função de criar antecipações e hipóteses sobre o tema do texto, mobilizando estratégias de leitura para ativar os sistemas de conhecimento dos alunos, trazendo-os para a interação com o texto. É interessante notar como, mesmo tratando de um assunto abstrato, a professora busca construir relações com os estudantes e suas vidas. Assim, depois de ler o título, traz um questionamento sobre os estudantes e ela mesma, pensando em todos como seres humanos: "Professora lê o título: O ar e os seres vivos. Professora: Nós dependemos do ar. Concordam?". Dessa maneira, estimula que comecem a construir antecipações sobre o texto e relacionem com questões da própria vida, criando a possibilidade de que construam sentidos ao que será lido depois. 
Depois, a professora segue o debate. É uma discussão bastante longa, que traz termos científicos, como respiração, gás oxigênio, gás carbônico e energia, mostrando que se trata de um texto com tema bastante abstrato.

"Professora: Por que a gente depende do ar?

Estudante A.: Pra gente respirar.

Professora: Pra gente respirar a gente depende do gás?

Estudante C.: Oxigênio.

Professora: Oxigênio. Certo? Mas só a gente que depende dos gases da atmosfera?

Estudante A: Não. As plantas também.

Professora: As plantas também. Só?

Estudante B: Os animais.

Professora: Os animais...

Professora: Então, existe algum ser vivo que não dependa do ar, de gases?

Estudante B: É... Bactérias.

Professora: Elas também precisam de gases...

Estudante A: Não nenhum. Nenhum seres vivos.

Professora: Nenhum ser vivo vive sem ar. Tá?

Professora: Então vamos lá. Todos os seres vivos dependem do ar para sobreviver. O processo que a gente precisa do ar, que todos os seres vivos precisam, a gente chama de res...

Estudantes.: "piração"

Professora: Que que é a respiração?

Estudante D: É respirar

Professora: O que significa respirar?

Estudante D: Puxar o ar.

Professora: Puxar o ar. Só que qual o gás que interessa na respiração?

Estudante A: O oxigênio.

Estudante B: Gás carbônico

Professora: Quando a gente puxa o ar?

Estudante A: Oxigênio

Professora: Lá no nosso pulmão a gente pega oxigênio. E o que que a gente joga pra fora?

Estudantes: Gás carbônico.

Professora: O gás carbônico.

Professora: Então vamos lá. Durante a respiração, o ser vivo faz o que? Pega?

Estudante E: O oxigênio...

Professora: O oxigênio do ar e dispensa o que?

Estudante A: O gás carbônico. 
Professora: Isso. Aí a gente já falou porque que a gente precisa pegar o gás oxigênio?

Estudante C: Pra respirar.

Estudante B: Pra gastar energia.

Professora: Para produzir a energia, através do alimento, do nosso combustível que é o alimento. Certo? Aí quando a gente libera energia do alimento, com o gás oxigênio, a gente produz o gás carbônico que a gente tem que soltar no ar. Certo?" (Notas do diário de campo e transcrição de audiogravação).

Nesse trecho percebemos que o diálogo proposto a partir do título segue com reflexões sobre fenômenos abstratos, relacionados às finalidades acadêmicas do ensino de Ciências, que nesse caso se associam às ciências de referência Fisiologia humana e Ecologia. Ao longo de todo o diálogo, a professora vai criando relações entre o que será lido e o que os estudantes realizam como processos fisiológicos, que é uma forma de criar conexões com o próprio corpo dos alunos e seus entendimentos do mundo. Percebemos isso nas perguntas colocadas pela professora: "Por que a gente depende do ar?”, “(...) Pra gente respirar a gente depende do gás?", “O processo que a gente precisa do ar, que todos os seres vivos precisam, a gente chama de res...", “Quando a gente puxa o ar? (...). Lá no nosso pulmão a gente pega oxigênio. E o que que a gente joga pra fora?" e "Aí a gente já falou porque que a gente precisa pegar o gás oxigênio?’.

A professora segue o diálogo, trazendo os outros seres vivos para a reflexão proposta, ampliando os conhecimentos que vão sendo ativados. Ela não pensa mais apenas nos seres humanos e seus próprios corpos e processos fisiológicos. Traz conhecimentos de mundo sobre as plantas e as relações com outros seres vivos. Vemos que, a partir das perguntas que incluíram os próprios alunos nas reflexões, a professora traz as vozes dos estudantes e assim amplia seus entendimentos sobre os fenômenos, refletindo sobre os seres vivos como um todo.

"Professora: Todos os seres vivos, com raras exceções, fazem isso. Pegam o gás oxigênio para liberar energia e soltam o gás carbônico.

Estudante C: Menos as plantas.

Professora: Menos algumas bactérias. As plantas também respiram, sabia?

Estudante C: Nem nariz elas têm!

Professora: Nem nariz elas têm. Por onde elas respiram?

Estudante A: Pelas folhas. 
Professora: Pelas folhas. Elas respiram também pelas folhas.

Professora: Só que as plantas, além de respirar, elas fazem uma outra coisa...

Estudante E: Elas fazem...

Estudante B: Fotossíntese.

Professora: Elas fazem fotossíntese. Vocês sabem por que as plantas fazem fotossíntese?

Estudante F: Eu não lembro.

Estudante B: Pra dar o oxigênio?

Estudante A: Para produzir alimento.

Professora: Para produzir alimento. Fotossíntese a planta faz pra produzir a comida dela. O nome da comida dela é glicose.

Estudante F: Que que é glicose?

Professora: É um tipo de açúcar.

Estudante F: Ela se alimenta de açúcar?

Professora: Como ela faz mais glicose do que ela precisa, ela junta glicose e faz fruta. Tá? As vezes acumula em algumas raízes fazendo cenoura, beterraba, em alguns casos, fazendo batata...

Estudante B: Cenoura?

Professora: Cenoura é raiz. Aí então, a planta, ela precisa fazer fotossíntese para produzir a comida dela, é o alimento dela. Por isso que a gente fala que ela produz o seu próprio alimento. Só que daí, quando ela faz fotossíntese para fazer comida para ela, ela acaba produzindo mais coisa. Ela acaba produzindo o gás oxigênio.

Estudante C: É! que legal!

Professora: Que quando ela produz a mais, ela solta pro ambiente. E aí quem usa o gás oxigênio?

Estudante B: A gente.

Professora: A gente. Esse alimento que ela faz, fica só para ela ou outros seres se aproveitam dele?

Estudante B: Não. Outros seres se aproveitam.

Professora: Incluindo quem?

Estudantes: A gente.

Professora: A gente, né?

Professora: Então ó. O que que a planta usa para fazer a fotossíntese? Vocês sabem?

Estudante A: Gás carbônico.

Estudante B: Ué. Energia solar.

Professora: Ela usa o gás carbônico...

Estudante B repete: Energia solar...

Professora: A energia solar... Tem mais coisa!

Estudante A: Água.

Estudante C: Sais minerais.

Professora: A água e precisa do auxílio dos sais minerais. 
Professora: Então olha só. Quando a planta faz fotossíntese, ela faz o que? Ela junta o gás carbônico que está na atmosfera.

Estudante B: A água...

Professora: Com a água que ela puxa do solo pelas raízes, usa a energia solar e os sais minerais para juntar essas duas coisas e produz a glicose, que é o alimento dela, e gás oxigênio.

Estudante C: Ela trabalha tanto pra fazer a comida dela e dos outros?

Professora: É. Ela trabalha muito pra fazer a comida dela.

Estudante G: Ainda bem...” (Notas do diário de campo e transcrição de audiogravação).

Percebemos que os estudantes participam da interação com a professora, respondendo às perguntas e construindo expressões em articulação com o que ela dizia, como quando um aluno fala " $E$ ! que legal!" ao ouvir que ao produzir o próprio alimento, as plantas acabam produzindo também o gás oxigênio. Também mostram participar da interação quando questionam a professora, por exemplo na comparação entre eles mesmos (seres humanos) e as plantas "Nem nariz elas têm!". A professora continua colocando no diálogo enunciados sobre os próprios estudantes, como, por exemplo, “(...). Que quando ela produz a mais, ela solta pro ambiente. E aí quem usa o gás oxigênio?", ou ainda "Esse alimento que ela faz, fica só para ela ou outros seres se aproveitam dele? (...). Incluindo quem?".

Assim, vemos que a professora consegue trazer os estudantes para a reflexão que propõe, criando relações entre o tema do texto e experiências de vida dos estudantes, ajudando-os a fazer antecipações e pensar sobre o tema proposto. Dessa forma, faz com que os alunos acessem seus conhecimentos de mundo, sobre processos fisiológicos, questões do mundo natural, relações entre os seres vivos, entre outros conceitos que provavelmente já discutiram em outras aulas de Ciências e trazem também do mundo social, da mídia, etc. A mobilização desses conhecimentos que permitirá que depois construam sentidos para o texto e, dessa forma, participem da atividade de leitura.

Além dos conhecimentos de mundo, associados a saberes enciclopédicos que os estudantes trazem sobre processos abordados no texto, os diálogos transcritos mostram a ativação e ampliação de conhecimentos linguísticos dos estudantes, com o auxílio da professora, que nesse caso se refere ao conhecimento lexical, ligado ao campo científico. Os alunos precisam nesse caso ativar conhecimentos do significado de termos como respiração, fotossíntese, alimentação, energia, ou necessitam criar sentidos que se aproximem ao que a 
professora está trazendo, de forma que a comunicação possa acontecer. Para ativação desse tipo de conhecimento a professora faz perguntas, como, " $O$ que significa respirar?", e também responde os questionamentos que os alunos apresentam: "Estudante F: Que que é glicose? Professora: É um tipo de açúcar. Estudante F: Ela se alimenta de açúcar?".

O trabalho com o texto ainda não terminou. A discussão antes da leitura em si continua. A professora segue construindo com os alunos reflexões sobre as plantas e a fotossíntese.

"Estudante G: Mas e se não tiver luz solar?

Professora: Aí ela não faz fotossíntese. (...) Então a planta faz fotossíntese de noite?

Estudante B: Não.

Professora: Não, não tem luz solar. Agora ela morre de fome? A planta de dia tá bonita, de noite ela tá morta?

Estudante E: Não.

Professora: Não. Por que não? Porque ela guarda a comida dela.

Estudante D: Que nem o efeito estufa!

Professora: É. A planta guarda a comida dela, o efeito estufa guarda os raios solares.

- Professora faz um esquema da fotossíntese no quadro para complementar a explicação. Tenta construir um raciocínio com os alunos relacionando fotossíntese e aquecimento global. Alunos acompanham.

Professora: E aí quando a planta faz fotossíntese, ela está tirando qual gás do ambiente?

Estudante C: Oxigênio.

Estudante A: Carbônico.

Professora: $\mathrm{O}$ gás carbônico. $\mathrm{O}$ que esse gás fazia quando estava um montão dele na atmosfera? Ela leva ao problema do?

Estudante A: Aquecimento global.

Professora: Aquecimento global. Então se a gente plantar um monte de árvores por aí, não derrubar mais árvores, isso vai ajudar ou vai prejudicar o aquecimento global?

Estudante B: Ajudar.

Professora: Vai ajudar. Por que a árvore ó, ela precisa do gás carbônico para fazer a comida dela.

Estudante B: Aí ela tira!

Professora: Ela tira da atmosfera. Só que aí a gente tem que estar sempre plantando árvores, não pode mais derrubar, não pode queimar. Aí ela produz comida que serve para todos os outros seres vivos que não sabem fazer. 
Professora: Ela ajuda, não atrapalha. Ela tira o gás do aquecimento global, melhorando a questão do aquecimento global. Produz comida que mantém todos os seres vivos vivos. Por que? Porque a vaquinha come a plantinha, a gente come a vaquinha, se não tiver plantinha para vaquinha comer, a gente come vaquinha?

(...)". (Notas do diário de campo e transcrição de audiogravação).

Essa parte da aula chama atenção pela intertextualidade, que participa de processos de leitura e compreensão de textos. De acordo com Koch e Elias (2015), a intertextualidade ocorre quando um texto está inserido em outro texto produzido anteriormente, que "faz parte da memória social de uma coletividade" (KOCH e ELIAS, 2015, pg. 86). Em uma perspectiva bakhtiniana, a intertextualidade está presente em todo e qualquer texto, visto que todo discurso é formado por enunciados que o antecederam. Todo enunciatário pressupõe "não só a existência da língua que usa mas também de enunciados antecedentes - dos seus e alheios com os quais o enunciado entra nessas ou naquelas relações (...). Cada enunciado é um elo na corrente complexamente organizada de outros enunciados" (BAKHTIN, 2016, pg. 26). Assim, a intertextualidade seria um componente fundamental das condições de produção de qualquer texto. No entanto, em alguns casos a intertextualidade fica mais explícita e a compreensão de um texto depende mais claramente dos conhecimentos que os interlocutores tem de outros textos. No trecho transcrito, considerando que todo o diálogo estabelecido faz parte da leitura do texto, vemos que a professora constrói claramente uma intertextualidade ao relacionar a fotossíntese com o aquecimento global. $\mathrm{O}$ tema do aquecimento global apareceu em aulas anteriores e nos textos da página 14 desse mesmo Caderno Pedagógico. Assim, ao trazer para o diálogo a questão do aquecimento global e relacioná-la com os seres vivos e as trocas de gases com a atmosfera, a professora constrói e ativa com os estudantes o conhecimento da intertextualidade, necessário para leitura e compreensão de textos. Destacamos que a professora continua ao longo de todo diálogo trazendo as vozes dos alunos através da construção de perguntas e de relações entre o tema abordado e a própria vida dos alunos "Porque a vaquinha come a plantinha, a gente come a vaquinha, se não tiver plantinha para vaquinha comer, a gente come vaquinha?".

Depois de toda essa discussão, chega o momento que a professora finalmente faz a leitura do texto: 
"Professora: (...) Aqui na página 20 então ó.

Estudante B: A gente já estava aqui.

Professora: Isso. Então vamos ler. E depois vamos responder as questões. Tá?

- A Professora lê a página 20. Vai explicando conceitos que aparecem. Lê com calma e entonação.

Professora lê: Podemos citar três processos que os seres vivos realizam e que estão relacionados ao ar atmosférico: a respiração aeróbica. Explica: respiração aeróbica significa que usa o gás oxigênio, tá? Continua lendo: realizada por muitos seres vivos Complementa: pela maioria dos seres vivos. Continua lendo: a fotossíntese, realizada por organismos como as algas e as plantas e o uso do nitrogênio atmosférico, realizado por alguns microrganismos. Durante a respiração aeróbica, ocorre uma troca de gases entre o organismo e o ambiente. Os seres vivos absorvem o gás oxigênio e eliminam o gás carbônico. Além de respirarem como os animais, as plantas também realizam outro processo fundamental na natureza chamado de fotossíntese. Nesse processo, que ocorre somente em presença de luz, a planta absorve o gás carbônico do ar e elimina o gás oxigênio, que ela fabrica durante esse processo. Explica: Claro que ela vai pegar oxigênio também para respiração.

Estudante D interrompe e continua o texto: Através da...

Professora continua a leitura: Através da fotossíntese, a planta produz seu próprio alimento. Fala em referência ao que está entre parênteses no texto (glicose): que é a glicose". (Notas do diário de campo e transcrição de audiogravação)

Em relação ao trecho descrito, é importante ainda comentar dificuldades que podem surgir para leitura e compreensão de textos do gênero discursivo científico. A compreensão de um texto varia segundo as circunstâncias de leitura e é determinada por uma série de fatores bastante complexos e inter-relacionados. Koch e Elias (2015) discutem que algumas vezes fatores relacionados a características do texto ou relativos ao autor ou ao leitor podem interferir no processo de compreensão ou interpretação de um texto, facilitando-o ou dificultando-o. Em relação ao autor ou leitor, a maior ou menor possibilidade de entendimento do texto dependerá de seus conhecimentos sobre os elementos linguísticos expressos no texto (como expressões, léxicos específicos, etc), de seus esquemas cognitivos, suas bagagens culturais e do conhecimento das circunstâncias de produção do texto. Considerando elementos do texto, os fatores que podem interferir na compreensão podem ser materiais (como tamanho das letras, qualidade da impressão, entre outros) e linguísticos ou de conteúdo (por exemplo, o léxico utilizado, estruturas sintáticas, pontuação, etc). Nas aulas de Ciências, o desconhecimento pelos estudantes de conceitos e fenômenos abstratos que são abordados pode dificultar a criação de sentidos para o texto, assim como o uso de 
um "código específico", relacionado aos termos científicos, e a estrutura sintática, relativa à linguagem científica. Por isso, nos textos desse gênero discursivo a mediação da professora parece ser ainda mais importante para trazer o conhecimento linguístico do campo lexical científico e sua sintaxe, para ativação de conhecimentos de mundo relativos a fenômenos abstratos e para criar relações entre diferentes textos. Nesse sentido, o diálogo que ela estabelece na leitura, antes do acesso ao texto propriamente dito é muito importante para que ele possa ser compreendido, mesmo que para isso, ela acabe incorrendo na restrição de sentidos possíveis. Os estudantes em sua entrevista comentaram sobre como essa professora os ajudava a compreender o texto. Um dos estudantes, ao responder se prefere quando a turma lê o texto em voz alta ou a professora, falou "Quando ela lê porque ela sabe explicar (...) Lê, para e explica. É mais fácil da gente entender". Assim, vemos que no debate dos textos de Ciências, a professora acaba por produzir processos de ensino-aprendizagem de leitura.

Trazemos agora outro exemplo de leitura com a utilização de textos do Caderno Pedagógico, mas desta vez de um gênero discursivo que mistura imagens e textos escritos, sendo, portanto, mais multimodal. A professora estava fazendo a leitura de um gráfico junto com os alunos da página 30 do Caderno Pedagógico do $3^{\circ}$ bimestre em um momento de correção de exercícios que os estudantes tinham feito na aula anterior (COORDENADORIA DE EDUCAÇÃO DO RIO DE JANEIRO, 2016 a, pg. 30). O gráfico mostrava a variação do nível de radiação ultravioleta no Rio de Janeiro de 26/04 a 01/05 (FIGURA 12).

\begin{abstract}
“- A Professora começa a correção da página 30 da apostila. Faz uma pergunta para análise do gráfico, diferente da que aparece na apostila. Vai ajudando os alunos a lerem o gráfico.

Professora: Vamos lá! Página 30. Primeiro eu quero que vocês olhem o gráfico e não quero saber de respostas que vocês colocaram na aula passada. Só olhem o gráfico! Olhem pro gráfico e quero que vocês me respondam. Só olhando pro gráfico, não é a pergunta que está aí. Qual é o dia em que o nível de radiação ultravioleta está aí no nível oito? Qual o dia ou quais dias?
\end{abstract}

Estudantes.: 26 e 27.

Professora: 26 e?

Estudantes: 27.

Professora: Depois do dia 27, esse nível de radiação aí aumentou ou diminuiu?

Estudantes: Diminuiu. 
Professora: Diminuiu para que nível?

Estudante A: Quatro.

Professora: Quatro. Depois, o que aconteceu com esse nível?

Estudante B: Subiu.

Professora: Subiu para quanto?

Estudante B: Subiu pra sete.

Professora: Sete. E depois do dia 29 do 4 ?

Estudante A: Nove.

Professora: Continuou aumentando, ficou a mesma coisa ou diminuiu?

Estudantes: Aumentou.

Professora: Aumentou ainda mais. Foi para que nível?

Estudantes: Nove.

Professora: Nove. E depois no dia primeiro do 5? Permaneceu, aumentou ou diminuiu?

Estudantes: Permaneceu.

Professora: Permaneceu e ficou no nove. Todo mundo consegue entender esse gráfico?

Estudantes: Sim!” (Notas do diário de campo e transcrição de audiogravação)

Dionísio (2008) coloca que a leitura de gráficos é uma atividade que pode ser bastante complexa, pois exige que o aluno integre informações visuais e escritas e acesse diversos tipos de letramentos. Rodrigues e Ribeiro (2017), ao discutirem atividades de eyetracking ${ }^{34}$ para leitura de gráficos, discutem como essa pode ser uma atividade difícil e sua importância para a contemporaneidade, visto que atualmente os gráficos estão presentes em variadas esferas da vida cotidiana. No trecho transcrito, a professora realizou um processo pedagógico de leitura de um gráfico. Ela não trouxe questões do contexto sociocultural dos alunos para o diálogo sobre o gráfico, mas os ajudou a antecipar hipóteses com a alusão ao que fizeram na última aula ("Primeiro eu quero que vocês olhem o gráfico e não quero saber de respostas que vocês colocaram na aula passada. Só olhem o gráfico!"'). Além disso, ao analisar o gráfico, ajudou os estudantes a acessarem conhecimentos de mundo sobre como ler um gráfico. Para isso, foi ajudando os alunos a verem relações entre cada dia mostrado no gráfico e o nível de radiação, além de contribuir

\footnotetext{
${ }^{34} \mathrm{O}$ conceito de eyetracking refere-se a um conjunto de tecnologias que permite medir e registar os movimentos oculares de um indivíduo perante um estímulo em ambiente real ou controlado, determinando, deste modo, em que áreas fixa a sua atenção, por quanto tempo e que ordem segue na sua exploração visual. Esse tipo de estudo é muito utilizado em pesquisas sobre o sistema visual, na psicologia, na linguística, entre outros.
} 
para que analisassem a trajetória da curva do gráfico ("Continuou aumentando, ficou a mesma coisa ou diminuiu?”). Os estudantes participaram do diálogo e não questionaram a professora, pareciam estar conseguindo ler o gráfico com segurança. Essa professora comentou em sua entrevista como se surpreendeu com a turma quando se propôs a ler um gráfico com eles a primeira vez: “(...) Olha, eu acho que nessa turma eu percebi que eles conseguem ler gráficos bem. (...) Então eu poderia falar até que gráficos, que costumam ter dificuldades, mas essa turma eu não percebi dificuldade com a leitura de gráfico. Eu fiquei bem surpresa". Apesar de pesquisas mostrarem as dificuldades para leitura de gráficos, como discutido, os estudantes conseguiram ler bem o gráfico e a professora não precisou investir fortemente nesse aspecto. Pode ser que por isso tenha escolhido não construir relações do gráfico com questões de vida dos alunos ou com outros textos. A ativação dos conhecimentos de mundo dos estudantes sobre leitura de gráficos foi suficiente para que dessem sentido ao que estavam lendo.

Atividades de leitura ocorreram com os diferentes gêneros discursivos que discutimos na seção anterior. Abaixo uma atividade de leitura que ocorreu integrando o gênero ilustração e o gênero mapa, na página 28 do Caderno Pedagógico do $3^{\circ}$ bimestre (COORDENADORIA DE EDUCAÇÃO DO RIO DE JANEIRO, 2016 a, pg. 28). Era um exercício escrito que a professora realizou junto com os estudantes, envolvia a leitura de um mapa político e um mapa do tempo do Brasil, além de ilustrações sobre o tempo, que apareciam como uma legenda. Para responder sobre o tempo em cada estado brasileiro, os estudantes precisavam localizar os estados no mapa político do Brasil, ler a legenda com ícones do tempo e depois associar o mapa político e a legenda a um mapa do tempo do Brasil:

“- Professora lê e explica o que deve ser feito no exercício.

Professora: Aí olha aqui ó. Lê: Com base na legenda da figura 3. Comenta: com base nessa legenda, olha o que vocês vão fazer. Lê: No mapa do Brasil com seus estados, descreva o mapa do tempo da imagem, figura 1.

Professora: A gente sabe os estados, se vocês não souberem por geografia, tem o mapinha aqui do lado e vocês vão dizer como vai estar o clima nesse local. Então aqui, Ceará, CE, vê aqui, como vai estar o tempo nesse local?

Estudante A: Ah! Já sei esse aqui. Esse daqui eu sei. Ceará é parcialmente nublado.

Professora: Beleza. Parcialmente nublado. Então no Ceará está parcialmente nublado. Esse eu não vou botar no quadro não. Só falar. Isso. Parcialmente nublado, na $a$.

Professora: Olha a Bahia, Bahia a sigla é BA. 
Estudante B: Parcialmente nublado.

Professora: Parcialmente nublado. Vê aqui, Bahia. Então a $b$ é parcialmente nublado. Rio de Janeiro?

Estudantes: Chuvoso.

Professora: Chuvoso.

Professora: Paraná, vocês acharam? PR. Aqui embaixo.

Estudante C: Pancada de chuva.

(...)

Professora: Rondônia. Rondônia é RO.

Estudante C: Pancada de chuva.

Professora: Pancada de chuva. Ó, o Acre.

Estudante B: Pancada de chuva.

Professora: O Acre é aqui na pontinha. Pancada de chuva, de novo.

Roraima. RR. Cá em cima.

Estudante C: Pancada de chuva.

Professora: Pancada de chuva. E o Amapá. AP?

Estudante D: Pancada de chuva.

Professora: Também pancada de chuva.

Estudante C: Pô professora, só tomamo pancada hoje.

Professora: Ninguém merece...”

Para ler essa ilustração e os mapas, a professora ativa diferentes sistemas de conhecimento junto com os alunos. Assim, ajuda os estudantes a acessarem seus conhecimentos de mundo ao reconhecerem o mapa como um mapa do Brasil, amplia esses conhecimentos integrando o mapa com os estados do Brasil ao mapa com ilustrações sobre o tempo. Atua também na mobilização e ampliação de conhecimentos linguísticos ao discutir as siglas de cada estado e relacionar com o nome por extenso. Aciona ainda aspectos de intertextualidade ao integrar os dois mapas e as ilustrações ("A gente sabe os estados, se vocês não souberem por geografia, tem o mapinha aqui do lado e vocês vão dizer como vai estar o clima nesse local"). Os estudantes participaram da atividade, mostrando que conseguiram fazer a integração e a leitura das imagens. Dessa forma, puderam interagir com os textos a partir da mediação da professora. Podemos perceber essa interação ao final do diálogo, quando o aluno traz um novo sentido para a ideia de pancada, antes associada à pancada de chuva "Pô professora, só tomamo pancada hoje".

Em todos os exemplos apresentados de observações nos quais processos de leitura ocorreram, estes foram realizados coletivamente entre as professoras e os 
estudantes. Cabe aqui uma problematização. Precisamos pensar em que momentos na escola os alunos acessam e mobilizam seus conhecimentos e estratégias para lerem os textos autonomamente, sem serem conduzidos pelas professoras. Esses momentos também foram observados com o uso dos Cadernos Pedagógicos. Nas três escolas houve momentos nos quais os alunos realizavam exercícios e leituras individualmente, embora no geral tenham sido menos frequentes que os momentos de leitura coletiva. Em uma das escolas, as aulas sempre se dividiam entre o uso do Caderno para uma leitura com toda a turma, na qual a professora lia a maior parte dos textos e dialogava sobre eles com os alunos, e depois momentos nos quais os estudantes liam individualmente e silenciosamente os textos e faziam os exercícios escritos. A professora então corrigia o Caderno Pedagógico de cada aluno e assim buscava perceber como cada um estava vivenciando os processos de leitura, escrita e acesso aos conteúdos de Ciências. A seguir, um momento no qual a professora comentou com a turma erros que percebeu ao corrigir individualmente os Cadernos dos alunos. Ela tinha explicado e lido textos coletivamente e nesse momento da aula tinha solicitado que eles fizessem as páginas 22, 24 e 25 do Caderno, lendo sozinhos os textos e respondendo às perguntas escritas (COORDENADORIA DE EDUCAÇÃO DO RIO DE JANEIRO, 2016 a, pg. 22, 24 e 25). Após corrigir individualmente vários Cadernos, a professora estabeleceu o diálogo abaixo com os estudantes, em interação com os textos que tinham lido e escrito:

\footnotetext{
“- A professora continua corrigindo as apostilas dos alunos. Dialoga com toda turma, a partir de erros recorrentes.

Professora: Gente olha só. Dá uma parada rapidinho aí. Mesmo quem já me entregou a apostila... Prestem atenção. Vocês estão confundindo o que é prevenção, o que é doença, o que é sintoma e microrganismo causador. Vamos lá. Gripe é o que?

Estudantes: Uma doença.

Professora: É uma?

Estudantes e Professora: Doença.

Professora: A doença é causada por um microrganismo. Qual é o microrganismo que causa essa doença? A gripe, no caso é o?

Estudantes: Vírus.

Professora: Vírus. Então a doença é a gripe e o vírus o microrganismo causador dessa doença. E qual é... Quais são os sintomas de quem tá com a doença gripe?

Estudante A: Tosse.

Professora: Tosse.

Estudante B:Febre.
} 
Professora: Febre, cansaço. Isso são sintomas. É o que você sente quando está com a doença, aí no caso gripe.

Professora: E qual é a forma de prevenção? Prevenção é o que você faz pra evitar ter aquela doença. Uma prevenção da gripe.

Estudante C: Lavar as mãos.

Professora: Lavar as mãos, não ficar em contato com pessoas que estejam doentes...

Estudante A: Ficar em lugares arejados.

Professora: Ficar sempre em lugares arejados. Então olha só. Doença é uma coisa. Microrganismo é o que causa aquela doença. Sintoma é o que você sente quando tem aquela doença e prevenção é formas de evitar. Alguns alunos estão embolando tudo. Ficou claro agora para vocês a diferença? Mesmo? Se eu perguntar e vocês errarem na prova, o que eu posso fazer com vocês?" (Notas do diário de campo e transcrição de audiogravação).

Com a correção individual dos Cadernos, a professora pode entender que estratégias e conhecimentos específicos precisavam ser mobilizados para que os estudantes criassem sentido para os textos. No trecho destacado, percebemos que os estudantes precisavam ampliar o sistema de conhecimento linguístico, especialmente lexical. A professora investe nesse processo dialogando com os alunos e trazendo exemplos para ajudá-los a significar os termos doença, microrganismo, sintoma e prevenção. Assim, atua diretamente no letramento linguístico dos estudantes. É importante colocar que momentos como esse foram menos frequentes que momentos de leitura coletiva, considerando o total de aulas observadas. Nesse sentido, cabe trazer a discussão sobre o tempo pedagógico. Seria fundamental que as professoras tivessem maior autonomia para dividirem o tempo como achassem adequado, sem serem pressionadas pelas avaliações externas, como viemos discutindo. Dessa forma, poderiam dedicar mais tempo para um trabalho individualizado de leitura e escrita com os estudantes, podendo atuar nos diferentes processos de cada estudante e ajudá-los a acessar, mobilizar e ampliar estratégias e sistemas de conhecimento mais específicos, de acordo com suas necessidades.

Para finalizar a discussão sobre o uso dos Cadernos Pedagógicos nas aulas de Ciências, apresentamos a seguir partes de momentos observados, buscando mostrar mais um pouco da diversidade de estratégias e conhecimentos que são mobilizados nas aulas para leitura e compreensão de textos. 
1) “- A professora segue para a página 12 e lê o texto sobre a Floresta da Tijuca.

Professora lê: A Floresta da Tijuca faz parte da unidade de conservação denominada Parque Nacional da Tijuca. No interior do Parque, estão localizados o Cristo Redentor e o Corcovado. (...). O Parque Nacional da Tijuca é, sem dúvida, peça fundamental para fazer do Rio a Cidade Maravilhosa.

- Professora destaca a fonte do texto: De onde veio essa informação?

Estudantes: www.icmbio.gov.br/parnatijuca/guia-do-visitante.html" (Notas do diário de campo e transcrição de audiogravação)

2) “- A professora chama atenção de onde a notícia veio e de quando ela é. Destaca a fonte do texto.

Professora: Sempre que vocês encontrarem um texto, vai ter de onde esse texto veio. A fonte do texto. É importante prestar atenção no título, na fonte e na data. É um texto recente ou antigo?" (Notas do diário de campo e transcrição de audiogravação)

Nestes dois pequenos trechos vemos que a professora ativou conhecimentos interacionais, discutindo com os alunos a importância de prestar atenção na fonte do texto, a data, o título. Para isso, é preciso acessar sistemas de conhecimentos sobre a estrutura de organização textual, para buscar o local onde normalmente a fonte está descrita no texto. É preciso também acessar conhecimentos de mundo e linguístico que permitam associar o termo fonte à origem daquele texto. Abaixo, há outros trechos que destacam discussões específicas associadas à mobilização de conhecimentos linguísticos:

1) "- A Professora lê o texto "Unidades de Conservação": Unidades de conservação são áreas em que a biodiversidade existente deve ser preservada.

- Interrompe a leitura para discutir o sentido de biodiversidade:

Professora: O que é biodiversidade?

Estudante A: Vida

Professora: Bio é vida. Diversidade significa tipos. Então biodiversidade, vários tipos de vida." (Notas do diário de campo e transcrição de audiogravação)

2) "Professora lê: O Parque, porém, é muito mais que isso, ele protege a primeira floresta replantada do mundo. Comenta: Isso, vamos lá, o que que é replantada?

Estudante A: Plantar de novo

estudantes: Plantar de novo". (Notas do diário de campo e transcrição de audiogravação)

3) "Professora: Na página treze, vocês já escutaram falar de espécies invasoras? 
Estudante A: Que?

Professora: Espécie invasora. O que que é uma coisa invasora?

Estudante B: Não é do lugar.

Professora: Não pertence ali. Algo que invadiu aquele lugar. Ih! Tem um monte de espécie invasora (...).” (Notas do diário de campo e transcrição de audiogravação)

4) “- A Professora lê a pergunta dois. Chama atenção para o plural, quais dias. Diz que muitos erraram isso. Os alunos respondem.

Professora: Dois. Em quais dias? Em quais dias. É um dia só ou é mais de um dia?

Estudantes: Mais de um dia.

Professora: Mais de um dia. Vocês erraram isso assim, muito! Lê o que está sendo perguntado. (...)" (Notas do diário de campo e transcrição de audiogravação)

No primeiro trecho, a ampliação do conhecimento linguístico dos alunos aparece na discussão lexical sobre o termo biodiversidade. A professora discute a formação da palavra, desmembrando-a nos significados de bio e de diversidade. Dessa forma, atua no sistema de conhecimento linguístico dos alunos. Nos segundo e terceiro trechos, a professora atua novamente no sistema de conhecimento linguístico lexical, ao dialogar com os estudantes sobre os sentidos das palavras invasora e replantada. No quarto e último trecho, a professora chama atenção para a palavra quais, discutindo com os alunos a necessidade de uma resposta no plural. Mais uma vez, há atuação sobre o sistema de conhecimento linguístico dos estudantes, desta vez em relação ao conhecimento gramatical.

A seguir, apresentamos mais um pequeno trecho, para mostrar a ativação do reconhecimento de um determinado tipo de gênero discursivo, nesse caso uma notícia de jornal.

"Professora: (...) No sul do Brasil tem, não chega a ser furacão, a gente tem tornados. Tornado é isso aqui (mostra na apostila a imagem no meio da notícia de jornal). Tornado são essas formações, parecido com furação só que o vento é menos forte, mais fraco, aí não faz tanto estrago.

Professora: Aí vamos ver aí, ó. Lê o título do texto "Saiu no Jornal": Tornado, chuva e ventania provocam estragos e deixam feridos no Rio Grande do Sul.

- A professora explica ao ler o título: no Rio Grande do Sul, é o RS.

Depois de ler o texto. Professora: Olha aí a formação do funil ó, a notícia é desse ano, 25 de abril." 
Inicialmente, a professora chama atenção para a fotografia da notícia (ajudando os estudantes em uma estratégia de antecipação do que tratará o texto), depois lê o título da seção do Caderno (“Saiu no Jornal”). Ativa um conhecimento linguístico sobre o significado de RS e ao final destaca a data da notícia. Ao ler o título "Saiu no jornal" e destacar ao final a data da notícia, a professora está ativando o conhecimento sobre gêneros discursivos dos alunos. Nesse gênero é sempre importante ter a data expressa no texto, é uma característica de gêneros desse texto.

Todos os exemplos que trouxemos até agora com o uso dos Cadernos Pedagógicos serviram para mostrar processos de ensino-aprendizagem relacionados a atividades de leitura. De fato, com os Cadernos muito mais conhecimentos e estratégias para leitura foram mobilizadas do que para escrita. As atividades de escrita que ocorreram com os Cadernos não permitiram a exploração de muitos conhecimentos para produção textual, visto que as propostas de escrita dos Cadernos que apareceram nas aulas foram de extração direta de informações dos textos. A seguir, apresentamos uma destas atividades. É uma atividade do Caderno do $4^{\circ}$ bimestre com três perguntas escritas articuladas a um texto, que é uma notícia de jornal sobre o aparecimento de um tubarão-baleia na praia de Copacabana, no Rio de Janeiro (COORDENADORIA DE EDUCAÇÃO DO RIO DE JANEIRO, 2016 b, pg. 07):

\footnotetext{
“- Professora segue para a página 7. Ela lê o texto e aguarda um tempo para os alunos fazerem o dever. São perguntas sobre o texto. Professora aguarda eles responderem individualmente.
}

Professora: Aí na página 7. Professora lê o enunciado: Leia a notícia e responda às perguntas. Comenta: Eu vou ler a notícia e depois vou dar cinco minutinhos para vocês fazerem.

Estudante A: O que?

Professora: A página 7. Então prestando atenção na notícia. Lê: Tubarão baleia atrai a atenção de banhistas na orla da Zona Sul do Rio. O animal chegou bem próximo a orla o que é bastante incomum. Apesar do tamanho o tubarão não oferece perigo, pois ele se alimenta de microrganismos e de peixes pequenos. O maior risco é para o próprio animal que pode se enroscar em uma rede de pesca e encalhar.

Professora: Aí tem essas três perguntinhas. Agora que eu vou dar um tempinho para vocês responderem isso aí.

(...)

- Depois de um tempo a professora corrige oralmente as perguntas.

Estudante E: Acabei

Professora: Quem já respondeu levanta a mão pra mim. 


\section{(...)}

- Professora confere que grande parte da turma levanta a mão, indicando que já terminaram de escrever.

Professora: Então vamos lá, a primeira questão. Lê: Apesar do tamanho, nosso habitante oferecia perigo aos banhistas?

Estudantes: Não.

Professora: Então é para botar não. A segunda, como se alimenta o tubarãobaleia?

- Muitos alunos respondem ao mesmo tempo.

Professora: De microrganismos e pequenos peixes.

Estudante B: Eu botei plâncton.

Professora: Tudo bem, pode ser. A gente vai falar mais do plâncton daqui a pouquinho. Aí a terceira...

Estudante F: A três eu não entendi.

- Diante da dúvida do aluno a professora responde antes de discutir com eles a questão três.

Professora: A terceira? Lê: Por que o tubarão -baleia corria risco no Posto 6? Explica: Ele tinha risco de encalhar. Ele tinha risco de encalhar se ele chegasse perto de uma rede, se ele ficasse muito próximo da areia ele podia não ter força para nadar de volta. Sabem como faz? Quando tem baleia que encalha e fica tentando ali e não consegue sair, algumas morrem, é difícil o animal é muito pesado. Vocês já viram aquele filme que na minha época passava... chamado "Free Willy"?

Estudante C: Eu vi

Professora: Era de um menino que começa a trabalhar com uma baleia (...)

Estudante B: Ah!!! Eu já vi já”. (Notas do diário de campo e transcrição de audiogravação)

Essa atividade de escrita exemplifica a maneira geral como ocorreram processos de escrita com o uso dos Cadernos nas aulas observadas. Como discutido na seção anterior (seção 4.3.1.1.2), as propostas de escrita dos Cadernos Pedagógicos são em sua maioria diretas e fechadas. As atividades observadas para escrita com a utilização do Caderno envolveram perguntas que exigiam apenas que os estudantes retirassem informações do texto e as repetissem. Para isso, precisavam apenas encontrar no texto o trecho que respondia ao questionamento feito. No trecho acima, encontramos as respostas às perguntas em uma pequena parte do texto: "Apesar do tamanho o tubarão não oferece perigo, pois ele se alimenta de microrganismos e de peixes pequenos. $O$ maior risco é para o próprio animal que pode se enroscar em uma rede de pesca e encalhar”; perguntas: “1) Apesar do tamanho nosso habitante oferecia perigo aos banhistas? 2) Como se alimenta o tubarão- baleia? 3) Por que o tubarão -baleia corria risco no Posto 6 ?". Estimula-se assim apenas uma repetição mnemônica, ou o "efeito papagaio" 
nas aulas de Ciências, como discutem Giraldi e Cassiani (2009). Não há espaço para articulação de textos diferentes, para busca de experiências e relações com o próprio contexto sociocultural ou para criação de múltiplos sentidos para o texto produzido. A forma de interação é controlada e restrita. Assim, há pouco espaço para autoria, para que apareça a individualidade do escritor. Claro que alguma autoria sempre haverá, visto que todo enunciado é individual, como nos coloca Bakhtin. Percebemos isso quando o estudante dá uma resposta diferente do que a professora esperava e do que estava escrito no texto: “Eu botei plâncton”. Ele buscou essa informação de outras aulas e outras discussões que tinham tido sobre o tubarão baleia, trouxe assim seu conhecimento de mundo para a conversa e para sua produção escrita, fez aparecer sua autoria. Mas, percebemos que isso acontecia em raros momentos, pois a forma como as perguntas são demandadas deixa pouco espaço para expressão da individualidade, pouco espaço para que a reconstrução de sentidos aconteça.

No trecho vemos ainda que, mesmo em uma atividade de escrita mais restrita, uma aluna colocou uma dúvida na última questão, talvez relacionada à compreensão na leitura da pergunta (“A três eu não entendi”). Para tentar resolver a dúvida, a professora busca trazer as vozes dos estudantes propondo um diálogo sobre um filme, criando uma relação entre a pergunta e o contexto cultural ("Quando tem baleia que encalha e fica tentando ali e não consegue sair, algumas morrem, é difícil o animal é muito pesado. Vocês já viram aquele filme que na minha época passava ... chamado "Free Willy"?").

Em síntese, os Cadernos Pedagógicos foram utilizados nas aulas de Ciências como principal fonte para leitura de textos variados. Através da mediação das professoras, os estudantes interagiam com os textos e mobilizavam diferentes estratégias e conhecimentos para darem sentido ao que era lido. Com gêneros discursivos diversos, perpassando diferentes enfoques curriculares e finalidades do ensino de Ciências, processos de ensino-aprendizagem de leitura foram realizados nas aulas através da maneira como as professoras propunham a interação com os textos dos Cadernos. Para mobilizar estratégias e conhecimentos usados na construção de sentidos na leitura, as professoras traziam contextos sociais e culturais de vida dos estudantes para interagirem com os textos, e assim possibilitaram a ampliação de conhecimentos linguísticos, de mundo e interacionais dos estudantes. No diálogo que travavam com os estudantes, as professoras 
construíam com os alunos antecipações e hipóteses para leitura dos textos. Dessa forma, percebemos que ao ensinar Ciências, as professoras acabam por ensinar processos de leitura de textos. Notamos também que isso acontece especialmente em momentos de leitura coletiva, sendo importante maior investimento do tempo pedagógico para momentos individuais de leitura, com trabalho em cima de demandas específicas de cada estudante. Os Cadernos permitiram principalmente processos de leitura, visto que as propostas de escrita eram muito fechadas e deixavam pouco espaço para autoria e para complexificar as produções textuais. Percebemos que outras atividades pedagógicas realizadas nas aulas permitiram mais o desenvolvimento de processos de ensino-aprendizagem relacionados à escrita. Na próxima seção discutiremos atividades de experimentação que foram observadas nas aulas de Ciências, relacionando com possibilidades de acesso à linguagem escrita vivenciadas a partir delas.

\subsection{2. \\ Experimentação escolar e possibilidades de leitura e escrita}

"Porque a gente vê o que a gente escreve". (Fala de uma estudante do sexto ano do ensino fundamental)

A realização de atividades experimentais no ensino de Ciências tem sido bastante discutida no nosso país, tanto no âmbito do campo de pesquisas na educação em Ciências quanto em documentos políticos, ressaltando sua importância e formas de incorporação mais consistentes ao cotidiano escolar. Diferentes pesquisadores reconhecem a importância de aulas práticas com experimentos para processos de ensino-aprendizagem de Ciências, mas problematizam a ideia de que a utilização de experimentação seria a solução de todos os problemas que o ensino de Ciências enfrenta (por exemplo, GIORDAN, 1999 e ROSITO, 2008). Ao mesmo tempo que surgem argumentos em defesa do papel crucial da experiência na aprendizagem de ciências, aparecem questionamentos relacionados a uma perspectiva histórica, que criticam a ênfase empírica que dominou as concepções de ciência e do seu ensino. Marandino et al (2009) discutem que a experimentação tem sido encarada como uma maneira metodológica para enfrentar a baixa aprendizagem em Ciências, como se essa 
problemática pedagógica fosse apenas uma questão do método utilizado. Nesse sentido, colocam que é preciso refletir sobre como esta prática tem sido entendida e realizada nas escolas, mas defendem que, apesar da necessidade de uma visão crítica, a experimentação pode realmente favorecer a aprendizagem de Ciências e deve ser incentivada e apoiada estruturalmente. Destacam que as aulas experimentais podem contribuir para a aquisição de conhecimentos e desenvolvimento mental dos alunos, principalmente se forem elaboradas de forma a estimularem o confronto de suas hipóteses iniciais com evidências empíricas de experimentos.

O termo experimentação tem um sentido bastante polissêmico no ensino de Ciências e tem sido utilizado para se referir a diferentes tipos de atividades práticas, relacionadas a variadas metodologias ativas de ensino-aprendizagem e à pluralidade dos campos científicos que integram o Ensino de Ciências. Nesse sentido, é importante definirmos o que compreendemos como experimentação. Temos como pressuposto a concepção de que os conhecimentos escolares e os conhecimentos científicos possuem especificidades e são diferentes um do outro, pois atendem a finalidades sociais distintas. Com esta perspectiva, defendemos que a experimentação que ocorre na escola para fins de ensino-aprendizagem de Ciências é diferente da experimentação que ocorre nos laboratórios de pesquisa científica. Como colocam Marandino et al (2009) "a experimentação escolar resulta de processos de transformação de conteúdos e de procedimentos científicos para atender a finalidades de ensino" (MARANDINO et al, 2009, pg. 103). Assim, embora a experimentação didática escolar tenha semelhanças com a experimentação científica (como vemos, por exemplo, na presença de alguns materiais que podem ser usados em ambas as esferas, tipo o microscópio ou a vidraria), ela possui características específicas. As atividades experimentais didáticas, por exemplo, visam demonstrar fenômenos científicos e não inventar novos conhecimentos das ciências como as experiências científicas. Além disso, a concepção de erro na experimentação didática e nos experimentos científicos é bem diferente: para a primeira se refere à dificuldade para o funcionamento da aula, enquanto para a outra se relaciona aos conhecimentos científicos capazes de serem produzidos. Entende-se também que as experiências didáticas são constrangidas pelo tempo e pela necessidade de produzir, em curto prazo, resultados de aprendizagem entre os alunos. Enfim, a experimentação que acontece nas escolas 
guarda semelhanças com o contexto científico, mas possui configurações muito próprias, pois não são experiências científicas "autênticas", embora não sejam totalmente desprovidas de certo caráter científico. Destacamos que a valorização da experimentação no ensino de Ciências se deve não apenas pelas relações com a experimentação científica, mas também por possuírem um caráter prático ou ativo, que se opõe a aulas expositivas. Porém, a experimentação se diferencia de outras práticas pedagógicas ativas devido a elementos que a aproximam de experimentos científicos e a diferem de outras atividades como jogos, simulações no computados, maquetes, etc.

Historicamente, a experimentação se tornou uma marca identitária dos docentes da disciplina escolar Ciências, pois são únicas, diferentes de atividades didáticas utilizadas em outras disciplinas da escola. Marandino et al (2009) trazem uma discussão sócio-histórica de como a experimentação didática acabou constituindo a disciplina escolar Ciências. Resgatamos essa discussão brevemente, buscando perceber como tais práticas foram sendo valorizadas e acabaram por ainda hoje caracterizarem a disciplina Ciências, aparecendo nas observações da nossa investigação.

Segundo as autoras, as ideias de ensino experimental ganharam maior visibilidade no currículo educacional do Brasil a partir da década de 1930, influenciadas pelo ideário da Escola Nova, como parte de um processo de modernização do país e propostas de desenvolvimento de metodologias mais ativas de ensino-aprendizagem. Nessa mesma época, a produção científica brasileira foi impulsionada pela criação das universidades, formando uma comunidade de cientistas e professores secundaristas com viés cientificista, devido à proximidade de formação nos bacharelados e nas licenciaturas. Nos anos de 1950, a defesa da realização de experimentações no ensino das ciências se fortalece e surge como um projeto nacional, com incentivo governamental para produção de materiais curriculares e formação docente. Nesse período e nas décadas seguintes, vários projetos curriculares surgiram no movimento de renovação do ensino de Ciências, inclusive impulsionados por financiamentos internacionais, tendo o ensino experimental como um dos traços marcantes comuns em todos eles. A experimentação como possibilidade de melhoria do ensino de Ciências surgia não só como uma forma de romper com metodologias consideradas "tradicionais" para melhoria da aprendizagem em Ciências, mas também como estratégia para o 
desenvolvimento científico e tecnológico do Brasil. Nesse contexto, a ideia de experimentação foi supervalorizada no ensino de Ciências, influenciando até hoje as disciplinas escolares ligadas aos campos científicos, entre elas a disciplina Ciências.

Na década de 1980, incentivos para melhoria do ensino de Ciências são deslocados para qualificação docente em nível acadêmico. Nesse novo momento, o ensino de Ciências através da experimentação passa a ser examinado como objeto de pesquisa acadêmica e "foi-se pondo maior ênfase nas críticas aos procedimentos do que propriamente na continuidade das ações iniciadas nas décadas anteriores" (MARANDINO et al, 2009, pg. 100). Chegamos na primeira década dos anos 2000, enriquecidos pelas críticas e análises acadêmicas, mas ainda à espera de encaminhamentos para o cotidiano escolar. Na prática, enfrentam-se ainda muitas dificuldades associadas ao contexto educacional para incorporação mais frequente da experimentação às aulas de Ciências, especialmente em relação às condições de funcionamento das escolas e aos processos formativos da profissão docente.

Em uma tentativa de refletir sobre a experimentação no ensino de Ciências na contemporaneidade, analisamos brevemente a Base Comum Curricular, para avaliação de como políticas curriculares atuais têm trazido discussões sobre esse tema (BRASIL, 2017). A Base da área de Ciências da Natureza, etapa do ensino fundamental, aborda experimentação ao mencionar a importância de processos investigativos para o ensino de Ciências, destacando que isso não significa apenas cumprir etapas em aulas no laboratório ou manipular objetos. Inclui as aulas experimentais em um espectro amplo que denomina de atividades de campo, junto com leituras, observações, visitas, aulas em ambientes virtuais, etc. Nesse sentido, menciona a importância de aproximar as crianças de procedimentos, práticas e processos de investigação científica, mas não discute aspectos mais específicos sobre aulas com experimentação. Em síntese, o documento apresenta crítica semelhante à de pesquisas da área, de que as experimentações didáticas por si só não garantem a aprendizagem em Ciências, há outras questões pedagógicas que precisam ser consideradas. Porém, não aprofunda a discussão e não considera questões específicas da experimentação didática, ao considerá-la em conjunto com outras metodologias ativas. Assim, não traz reflexões sobre formas de aproximação e diferenciação destas atividades de experimentações científicas strictu sensu e nem discute seu papel no ensino. 
Marandino et al (2009) colocam que, apesar das adversidades, os professores de Ciências têm sido sensíveis à valorização da experimentação didática em suas aulas, produzindo práticas em seu cotidiano, mesmo que muitas vezes não sejam socializadas de forma devida. As autoras destacam publicações docentes da educação básica que aparecem em encontros da área de ensino de Ciências e Biologia (por exemplo, Encontro Nacional de Ensino de Biologia e Encontro Regional de Ensino de Biologia), e incluem inúmeros relatos de trabalhos com experimentação desenvolvidos pelos professores em suas aulas. Em nossa investigação, percebemos também a valorização da experimentação pelas professoras e observamos a realização desse tipo de atividade em diferentes aulas.

Nas entrevistas, a experimentação apareceu como característica marcante das aulas de Ciências, como vemos nas falas dos alunos:

\author{
"Estudante A: Eu gosto das aulas de Ciências porque é legal! \\ Pesquisadora: Mas o que você faz que você acha legal nas aulas de \\ Ciências? \\ Estudante A: Os experimentos! \\ (...)
}

Estudante B: Eu gosto por causa dos experimentos." (Grupo de alunos de uma das escolas investigadas).

"Estudante A: Eu gosto por causa das experiências que a professora faz! Estudante B: Ah... Por causa que eu acho legal trabalhar com aula prática. É legal isso." (Grupo de alunos de uma das escolas investigadas).

"Estudante A: A melhor prática foi quando ela pegou o ovo, pegou uma garrafa e botou assim...

Estudante B: É, aí botou o ovo!

Estudante A: Aí botou um ovo e acendeu assim, aí botou fogo e aí o ovo desceu.

Estudante C: Foi muito legal!" (Grupo de alunos de uma das escolas investigadas).

"Pesquisadora: O que que você acha que tem de legal?

Estudante A: Experimento!" (Grupo de alunos de uma das escolas investigadas).

"Pesquisadora: E vocês lembram de alguma coisa que vocês fizeram na aula de Ciências esse ano que vocês tenham achado assim muito legal? Estudante A: Tem o experimento.

Estudante B: O experimento!" (Grupo de alunos de uma das escolas investigadas).

Pesquisas sobre experimentação no ensino de Ciências destacam que essas atividades tem uma função importante de motivar e despertar a atenção dos alunos 
(OLIVEIRA, 2010). Giordan (1999) coloca que estudantes e professores costumam atribuir um caráter motivador às atividades experimentais. Da mesma forma, Marandino (2018) destaca que muitos dos argumentos que têm sido usados na defesa da experimentação, enfatizam dimensões cognitivas, afetivas, de motivação e atitudes. Percebemos isso também nas nossas entrevistas, quando as memórias prazerosas que as crianças trouxeram das aulas de Ciências eram relacionadas principalmente aos experimentos didáticos. As falas das crianças reforçam como a experimentação assinala a identidade da disciplina escolar Ciências e a afetividade envolvida nessas práticas. Além do aspecto motivador, Oliveira (2010) chama atenção para outras finalidades da experimentação no ensino de Ciências. As mesmas incluem o desenvolvimento da capacidade de trabalhar em grupo, o incremento da iniciativa pessoal e da tomada de decisão, o estímulo à criatividade, o aprimoramento da habilidade de observação e registro de informações, a aprendizagem de análise de dados e de propor hipóteses, a aprendizagem de conceitos científicos, entre outros. Na nossa investigação, acrescentamos outra finalidade ao uso de experimentação no ensino de Ciências, o desenvolvimento de processos de ensino-aprendizagem da linguagem escrita. Os estudantes trouxeram em suas falas reflexões importantes nesse sentido:

\footnotetext{
"Pesquisadora: (...) Porque vocês falaram que gostam muito de experimentos, né? Sempre na aula de experimentos têm coisa para escrever?

Estudante A: Tem. Ela passa umas perguntas sobre o que a gente entendeu. (...)

Pesquisadora: Quando vocês têm que escrever a partir do experimento vocês gostam mais do que escrever só do texto?

Estudante B: É.

Pesquisadora: Vocês acham que dá para entender melhor?

Estudante B: Dá. Porque a gente vê o que a gente escreve." (Grupo de alunos de uma das escolas investigadas).
}

Na fala, os alunos destacam de novo o prazer relacionado à experimentação, inclusive na atividade de escrita, e nos ajudam a refletir sobre o potencial de processos de aprendizagem de escrita a partir de aulas com experimentação, ao destacarem como a concretude, a vivência daquilo sobre o qual vão escrever, amplia a possibilidade de produção textual "Porque a gente vê o que a gente escreve". 
As professoras investigadas também trouxeram falas importantes para reflexão sobre a articulação entre atividades de leitura e de escrita e a experimentação didática nas aulas de Ciências:

\begin{abstract}
"Sim, é uma coisa que eu sempre...nas aulas práticas eu sempre coloco, faço um roteiro e coloco questões que eles tenham que explicar o porquê dos fenômenos que eles veem nas práticas. E eles têm mais facilidade de fazer isso na aula prática do que na avaliação teórica. (...) Um exemplo. Eu dei aula prática sobre o ar e aí uma das atividades eles tinham ... tinha um ovo na garrafa, o ovo entrava na garrafa. E aí durante a prática eles conseguiram na questão explicar que a pressão externa era maior e empurrava o ovo para dentro. Praticamente todos conseguiram (...). Conseguiram construir essa resposta. E aí na prova eu fiz uma pergunta mais ou menos parecida sobre pressão, o calor que expande as moléculas e tudo mais, eles já tiveram mais dificuldades. (...) Na prática (...) Eu acho que eles veem o fenômeno ali naquele momento e eu vou fazendo... eu vou direcionando as perguntas de acordo com o que eles observam, de acordo com as respostas deles. Eles veem que o ovo entrou. Por que que ele entrou? Porque $\mathrm{o}$ ar que estava dentro sugou. Eu falo: ué, mas estava fechado, como é que sugou? Ah, não sei, tinha alguma força. E de onde vem essa força? O que que tem aqui fora? E aí eu vou direcionando as perguntas conforme as respostas deles. Na avaliação não tem essa dinâmica. (...) É uma pergunta e eles têm que responder. (...) A prática tem o concreto e eu consigo direcionar melhor a resposta deles. (...) Ali eles conseguem. Eles conseguem escrever mais". (Fala de uma das professoras investigadas).
\end{abstract}

Destacamos nessa fala duas questões importantes para a articulação entre a realização de experimentos nas aulas e processos de escrita vivenciados pelos estudantes. Primeiro, destacamos o fato de que a professora diz que sempre nas aulas experimentais ocorrem processos de produção escrita. Assim, essas atividades didáticas são também um momento de ler e, principalmente, de escrever. Outra reflexão importante que a professora traz se refere à afirmação de que nas aulas de experimentação os estudantes conseguem escrever melhor que em outros processos pedagógicos (nesse caso, as avaliações formais, isto é, provas e testes). A professora acredita que esse fato se relacione à forma como ela conduz a discussão durante o experimento, associada à atividade de escrita. Além disso, ela menciona a possibilidade de vivenciarem concretamente uma situação antes de escreverem sobre ela. A fala de outra professora também discute como os alunos conseguem muitas vezes escrever melhor nas aulas experimentais que em outros tipos de aulas:

"Não sei se você lembra do F. O F. ele fica lá na frente. Um baixinho que gosta de jogar bolinha de gude. E ele... quando a gente... quando é só aula mesmo, ele não capta o conteúdo. Mas, nas aulas práticas ele presta atenção. Ele gosta. E aí na prova você via que ele tem o conteúdo das aulas práticas. Ele vai lá e coloca, escreve. Escreve assim não direitinho, ele não 
escreve nada direito. Ele bota tudo errado, sem as palavras, não forma frases, mas você compreende o... o que ele quis dizer. O raciocínio. E o raciocínio veio da aula prática. Então ele coloca ali do jeito que ele consegue colocar, o que ele participou da aula. E aí é... mas falta muito porque não dá para trabalhar todo o conteúdo com a aula prática. Então o que foi feito de aula prática ele faz. O que não foi de aula prática ele não faz. (...) É a única justificativa. Ele interage com a aula prática, mas não interage com o conteúdo só teórico. Só falando, só com exercício ele não consegue". (Fala de uma das professoras investigadas).

Nessa fala, a professora traz a ideia de que o aluno é capaz de escrever melhor quando parte de uma interação concreta para desenvolver seu texto. É somente a partir da interação social que vivencia que ele tem a possibilidade de escrever. Trazemos essa fala para enaltecer como as aulas práticas podem potencializar a escrita. Claro que não podemos idealizar essa questão, a própria professora coloca que ele não escreve com correção gramatical, que não consegue escrever sobre todo conteúdo explorado nas aulas, mas é capaz de produzir e construir sentidos através de um texto escrito. Defendemos que é a partir da expressão do próprio aluno que devemos pensar os processos de ensinoaprendizagem da escrita.

A seguir apresentamos mais uma fala de uma das professoras para contribuir com as reflexões:

\begin{abstract}
"Eu fiz com eles dois dias diferentes de experimento. E aí é uma coisa que eu também tenho muito forte na minha formação, que eu gosto muito, mas por $\mathrm{n}$ motivos é muito mais difícil fazer no município. Mas, eu fiz experimento simples que foi de observação. (...). Botei eles em grupo e aí foi muito mais conversa e aí eles falavam e eles acertaram. Tinha uma aluna lá que já tinha feito não sei onde, falava, foi muito legal. E aí depois eu falei, então tá bom. Então agora vocês vão colocar isso no papel, só que eu não deixei livres. Escrevam o que aconteceu, porque eu sabia que ia dar um nó na cabeça deles. Eu fiz assim, que eles escrevessem o que aconteceu, mas de forma orientada. Eu fui fazendo perguntas. Por exemplo, que materiais nós usamos? Aí, é, o que foi feito no experimento? Aí eles iam respondendo. Que eu lembre foi a aula que eles mais escreveram e eu acho que foi bem legal. (...)". (Fala de uma das professoras investigadas).
\end{abstract}

Algumas questões importantes podem ser trazidas a partir da fala dessa professora. A primeira, reforçando o que as outras professoras colocaram, é o potencial de escrita que as atividades de experimentação podem apresentar, de acordo com a professora, a aula com experimentação "foi a aula que eles mais escreveram e eu acho que foi bem legal”. Outra questão, é a motivação e participação dos alunos, que ela destaca "Botei eles em grupo e aí foi muito mais 
conversa e aí eles falavam e eles acertaram. Tinha uma aluna lá que já tinha feito não sei onde, falava, foi muito legal”.

Ela coloca ainda uma problemática fundamental para refletirmos sobre a experimentação no ensino de Ciências, a frequência deste tipo de atividades nas aulas. As três professoras valorizaram a realização de experimentos, comentaram sobre a importância desse tipo de atividades e relacionaram com a sua formação docente, como essa professora traz "E aí é uma coisa que eu também tenho muito forte na minha formação, que eu gosto muito (...)". Os alunos também mostraram um forte interesse e motivação para realização de aulas com experimentação. Mas, apesar disso, a frequência de observação desse tipo de aulas foi baixa. Dos 59 tempos observados, apenas em 5 deles ocorreram atividades com experimentação (aproximadamente $8 \%$ das aulas), o que representa um número pequeno se compararmos com os tempos nos quais houve utilização dos Cadernos Pedagógicos (32 tempos de aula) ou avaliações formais (19 tempos de aula) ${ }^{35}$. Reflexões sobre experimentos apareceram também em outros momentos das observações, como nas avaliações e em discussões em sala de aula, relembrando o que realizaram em outros momentos, porém experimentos didáticos só aconteceram mesmo nestes 5 tempos de aula. Ao discutir a baixa ocorrência de aulas com experimentação em seu cotidiano, a professora diz que "por $n$ motivos é muito mais dificil fazer no municipio". Marandino et al (2009) discutem que embora muitos professores desejem ampliar as oportunidades de aulas práticas laboratoriais, nem sempre conseguem superar as dificuldades encontradas no cotidiano escolar. Segundo as autoras, estas se referem principalmente à ordem estrutural, ao tempo curricular, à insegurança em ministrar essas aulas e ao grande número de alunos nas turmas. Nos contextos que encontramos em nossa investigação, acreditamos que a principal questão que influencia na não realização de aulas práticas é o tempo pedagógico. Marandino et al (2009) colocam que elementos associados às tradições de ensino da escolaridade brasileira mantém uma cultura enciclopédica, favorecida pela forma de funcionamento das escolas e pela pressão das avaliações externas. Percebemos que nos Cadernos Pedagógicos mencionam-se variadas atividades com experimentação, assim como nas provas elaboradas pela prefeitura. No entanto, em

\footnotetext{
${ }^{35}$ Esclarecemos que em alguns tempos de aula ocorreram atividades pedagógicas de mais de um tipo (uso dos Cadernos e experimentação; avaliação e uso dos Cadernos, etc.)., e em algumas aulas outros tipos de atividades ocorreram (uso de vídeos, uso de caderno dos alunos, entre outros).
} 
contradição, a pressão por trabalhar um conteúdo extenso em um curto período influencia fortemente o tempo pedagógico e as professoras acabam por optar pela não realização de práticas experimentais, que acabam ocorrendo com baixa frequência. Há uma dificuldade enorme em administrar o tempo e encontrar espaços curriculares para desenvolver essas atividades. Além disso, questões estruturais relacionadas ao tamanho das turmas também parecem influenciar.

A fala da professora traz outro aspecto importante para análise, a forma como organiza as atividades de escrita durante a experimentação. Ela diz que quando realizou a experimentação, ao solicitar que escrevessem sobre a prática “(...) eu não deixei livres. Escrevam o que aconteceu, porque eu sabia que ia dar um nó na cabeça deles. Eu fiz assim, que eles escrevessem o que aconteceu, mas de forma orientada. Eu fui fazendo perguntas. Por exemplo, que materiais nós usamos? Aí, é, o que foi feito no experimento? Aí eles iam respondendo". A primeira fala que destacamos também traz reflexões sobre a forma como coloca demandas de escrita nas aulas experimentais " $\mathrm{eu}$ vou direcionando as perguntas de acordo com o que eles observam, de acordo com as respostas deles". Com essas falas percebemos como as professoras usam estratégias para que as crianças produzam textos escritos. Atuam especificamente na orientação da escrita para que os estudantes consigam avançar e escrever. No trecho da entrevista abaixo, a professora continua a discussão sobre como orienta a escrita durante as atividades de experimentação:

\footnotetext{
"Foi tudo na conversa. Porque, assim... a aula não foi direta eu falando para depois escrever. Foi passo a passo, porque se não eles ficam perdidos. Você tem, você tem que orientar o tempo inteiro. Se não eles, se você espalhar demais, eles não conseguem começar e fazer início, meio e fim.(...) Então primeiro eu fiz a parte do que que eles achavam que ia acontecer. Aí eles foram falando ideias, não sei o que. Eu fui puxando também algumas coisas. Aí eu falei, tá então agora escreve. Aí depois que eu fiz o experimento, aí o que aconteceu? Aí a gente discutiu, não sei o que, aí eles colocaram no papel". (Fala de uma das professoras investigadas).
}

Vemos que a professora realiza atividades de escrita em diferentes etapas da atividade de experimentação, incluindo levantamento de hipóteses e descrição de resultados, criando oportunidades de escrita em cada uma destas etapas. Os estudantes interagem com as etapas da experimentação e imediatamente realizam a produção textual, o que pode ser importante para a formação dos estudantes em relação à escrita. Dessa forma, talvez eles possam no futuro escrever e organizar 
seus textos sem precisarem de tanta orientação e interação imediata. Como a própria professora reforça na seguinte fala, quando compara as atividades de mesmo tipo entre anos de escolaridade distintos:

\begin{abstract}
“(...) Nem que seja de forma orientada como eu fiz no sexto ano. Aí no sétimo eu acho que dá para deixar a coisa mais, mais solta. Mas no sexto ano, mesmo sendo de forma orientada, eu acho que isso já é um avanço, deles tentarem se esforçar e formular com as próprias palavras as ideias deles, o que eles pensam sobre alguma coisa..." (Fala de uma das professoras investigadas).
\end{abstract}

Para trazermos mais reflexões sobre como a experimentação se associa a atividades de leitura e de escrita, na próxima seção do texto apresentamos momentos de observação de aulas nas quais esse tipo de atividade ocorreu.

\title{
4.3.2.1. Observações de leitura e escrita em atividades de experimentação escolar
}

$\mathrm{Na}$ primeira situação de observação apresentada a seguir, a prática foi realizada em sala de aula, de forma demonstrativa, isto é, a professora fez os procedimentos e os alunos assistiram. Essa experimentação aconteceu no final da aula. Antes, tinham trabalhado com correção de exercícios, com a leitura e diálogo sobre textos do Caderno Pedagógico e com cópia de texto do quadro. Observamos que a ideia do experimento apareceu na aula antes do momento de realizá-lo, como uma solicitação dos alunos e como uma forma da professora incentivá-los a realizarem outras atividades.

\footnotetext{
“- Aluna pede aula prática. A professora diz que vai ver, dependendo do andamento do conteúdo. (...)

Professora: Vamos para o caderno rapidinho. Se vocês copiarem rapidinho, a gente vai fazer o experimento." (Notas do diário de campo e transcrição de audiogravação).
}

Destacamos nesse trecho a o envolvimento dos alunos com a possibilidade de vivenciarem uma atividade de experimentação. O pedido de fazerem um experimento e o fato da professora trabalhar com esse desejo para conseguir que fizessem outras tarefas, mostra o elemento motivacional e afetivo da experimentação. Como dissemos anteriormente, esse aspecto motivador tem sido 
utilizado como um dos principais argumentos para defender a realização de experimentos no ensino de Ciências (GIORDAN, 1999).

No momento da aula dedicado à experimentação, antes de começar efetivamente o experimento, a professora escreveu uma pergunta no quadro e a discutiu. Era uma pergunta sobre o experimento que deveria ser respondida de forma escrita depois que esse fosse realizado.

\footnotetext{
"Hora: 16:29 h.

- Professora escreve "Experimento" no quadro.
}

Estudante A: Professora, qual é o nome desse experimento?

Professora: Então, esqueci que tem uma pergunta do experimento. Então bota assim ó, experimento. Vou botar a pergunta aqui! É uma só. A pergunta do experimento.

- Professora escreve no quadro, depois do texto do caderno: Experimento

O gás carbônico é um gás comburente? Por que?

Estudante B: O que é isso?

Professora: É a pergunta do experimento.

Estudante C: O que tá escrito ali professora?

Professora: Comburente!

Professora: A gente fez aquele experimento da vela, que a gente falou que um pesquisador fez também lá em 1700, né? Que a gente pegava uma vela, acendia e botava um copo em cima. $\mathrm{E}$ a gente via que quando fechava a vela com copo de vidro, o que acontecia com a chama da vela?

Estudante A: Apagava.

Professora: Por que apagava?

Estudante A: Oxigênio.

Professora: Então acabava o gás oxigênio e a chama apagava. Aí a gente falou que o oxigênio então era o gás que mantinha a chama acesa, o gás que mantem a chama acesa, a gente chama de comburente. Lembram desse nome?

Estudante C: Não lembro não.

Professora: Gás comburente mantém a combustão, o gás que mantém a chama, o fogo aceso. Então anota a pergunta que eu vou explicar o que a gente vai fazer. Anota aí essa pergunta que depois a gente responde. Três minutos para começar a fazer". (Notas do diário de campo e transcrição de audiogravação).

Acreditamos que a professora, ao discutir a pergunta oralmente, atua tanto na mediação da leitura da questão, quanto na mediação da atividade de escrita que acontecerá após a realização do experimento. Ela cria sentido para a cópia escrita da pergunta que os estudantes estão realizando, mas, principalmente, mobiliza conhecimentos para que possam começar a interagir com o experimento e ativar 
estratégias e conhecimentos que serão utilizados depois para escreverem sobre ele. Trabalhamos, com base em Koch e Elias (2015 e 2017), com o pressuposto de que a leitura e a escrita são processos complexos que dependem de conhecimentos e estratégias sócio-cognitivas que o autor e o leitor mobilizam para participar de uma interação social entre autor-texto-leitor. $\mathrm{O}$ entendimento da escrita como atividade sociointeracionista, considera que sempre se escreve para alguém (ainda que esse alguém seja a gente mesmo) e que aquilo que se escreve é revisto continuamente pelo produtor do texto para se ajustar a sua intenção e ao desejo que o leitor a compreenda, visto que estão em interação. Assim, o escritor relê seu texto enquanto escreve, reformula trechos, suprime trechos e acrescenta informações, de forma a ir moldando seu texto em um processo complexo que sempre pressupõe a existência do outro e a possibilidade de interação com ele. O autor cria um modelo de leitor e escreve refletindo sobre esse modelo.

\begin{abstract}
Dizendo de outro modo: a escrita pressupõe sempre o leitor e, na base disso, encontra-se o princípio da interação, que privilegia a negociação entre os sujeitos, a intersubjetividade, os conhecimentos sociocognitivamente constituídos e significados, a língua situadamente em uso, o dizer e o redizer. (KOCH e ELIAS, 2017, pg. 51).
\end{abstract}

Para ler e escrever, são mobilizados diferentes estratégias e sistemas de conhecimento, isto é, sistema de conhecimento linguístico, sistema de conhecimento de mundo e sistema de conhecimento interacional, incluindo o sistema de conhecimento de textos. Desde o início da aula de experimentação, percebemos a ativação de alguns desses sistemas. Inicialmente, destacamos a ativação do conhecimento linguístico, que nesse caso se refere ao conhecimento de signos do campo lexical científico e aparece na discussão do significado do termo comburente. No diálogo sobre o significado do termo, a professora aciona o sistema de conhecimentos de textos, ao trazer para a cadeia discursiva textos que tinham usados anteriormente na aula ("A gente fez aquele experimento da vela, que a gente falou que um pesquisador fez também lá em 1700, né?”). Para lerem o termo comburente e darem sentido à pergunta, dialogam com um experimento realizado em outra aula e com um texto do Caderno Pedagógico que descreve um experimento histórico realizado por Priestley no século XVIII ${ }^{36}$

\footnotetext{
${ }^{36}$ Foi observada uma aula na qual este texto foi trabalhado. O momento de trabalho com o texto está descrito na seção 4.2 da presente tese.
} 
(COORDENADORIA DE EDUCAÇÃO DO RIO DE JANEIRO, 2016 a, pg. 21).

Assim, embora a intertextualidade não apareça na pergunta escrita em si, foi ativada como forma de reflexão para dar sentido à leitura da questão e pode ter influenciado a escrita posterior dos alunos. Por fim, nessa discussão inicial vemos que há a ativação do sistema de conhecimento de mundo, que se refere aos conhecimentos de questões do mundo que temos arquivado na nossa memória a partir do que falamos, lemos e adquirimos com nossas experiências e vivências. A professora ativou conhecimentos dos alunos a partir de outras aulas, trazendo conhecimentos sobre o que mantém o fogo aceso, sobre os gases e outros conhecimentos científicos das aulas de Ciências. Ela supunha que esses conhecimentos estivessem na memória dos alunos, leitores da pergunta colocada e escritores da resposta que depois foi elaborada.

A aula continuou e novos conhecimentos foram sendo mobilizados. Após discutir a pergunta, a professora dialogou com os alunos sobre o que seria feito no experimento:

“- A professora espera um pouco para eles escreverem a pergunta e vai organizando os materiais do experimento na sua mesa.

Professora: Vamos comparar o gás oxigênio que a gente sabe que é necessário para manter a chama acesa com outro gás, que é o gás carbônico.

- A professora explica o que vai fazer no experimento. Diz que o vinagre e o bicarbonato geram gás carbônico. Depois explica o que deve acontecer se o gás carbônico for ou não comburente.

Professora: Mas como eu vou fazer para botar o gás carbônico aqui? Difícil. Aí o que eu vou fazer? Peguei água. Vocês lembram que a gente fez o vulcão?

Estudantes: Sim.

Professora: Vocês lembram que o vulcão entrava em erupção?

Estudantes: Sim.

Professora: Para o vulcão entrar em erupção a gente usava vinagre e bicarbonato de sódio. A gente vai usar isso aqui de novo. (...) A reação do vinagre com o bicarbonato solta qual gás?

Estudante A: Carbônico.

Professora: Gás carbônico, que faz aquela espumazinha, bolhinhas de ar. Certo? Então eu vou criar um ambiente aqui que tenha gás?

Estudantes: Carbônico.

Professora: Carbônico. Se o gás carbônico for igual ao gás oxigênio, a chama vai ficar acesa ou vai apagar?

Estudante B: Vai apagar.

Estudante C: Vai ficar acesa. 
Professora: Se ele for igual ao oxigênio, ou seja, se ele for um gás comburente, a chama vai ficar acesa. Mas e se ele não for, o que vocês acham que vai acontecer?

Estudante A: Vai apagar!

Professora: Então podem vir". (Notas do diário de campo e transcrição de audiogravação)

Nesse trecho, destacamos o fato da professora colocar para os alunos os objetivos do experimento ("Vamos comparar o gás oxigênio que a gente sabe que é necessário para manter a chama acesa com outro gás, que é o gás carbônico"), que se associa à pergunta escrita que devem responder ao final (“O gás carbônico é um gás comburente? Por que?"). Assim, a interação com o experimento começa a ser estabelecida a partir das reflexões que a professora traz em relação ao objetivo da experimentação, que depois influencia a escrita sobre ele. Ao discutir o objetivo do experimento, a professora mobiliza estratégias e conhecimentos que ajudam os estudantes a pensarem sobre a atividade que estão vivenciando e a partir dela realizarem uma atividade de escrita. Defendemos que ao discutir os objetivos do experimento, a professora atua na ativação do sistema de conhecimento interacional envolvido no processo de escrita. Esse sistema de conhecimento diz respeito à ativação de modelos cognitivos sobre variadas práticas interacionais, constituídas historicamente e culturalmente. A partir desses modelos, o produtor busca configurar na escrita sua intenção, de forma que seja possível para o leitor reconhecer o objetivo ou propósito do texto (ou do quadro interacional colocado). Dessa forma, o produtor/escritor busca garantir a interação com o leitor. Para isso, determina a quantidade de informação necessária para que o leitor possa compreender o que ele deseja, seleciona o gênero que deve ser usado e sua variante linguística, além de escolher utilizar ou não apoios textuais, como marcações e sinalizações no texto (KOCH e ELIAS, 2017). Essas escolhas e a forma como aparecem no texto escrito dependem principalmente dos objetivos da interação, isto é, dos objetivos do autor ao escrever aquele texto. Acreditamos que a discussão dos objetivos da realização da experimentação, ativa conhecimentos envolvidos na escrita sobre ele. Nesse caso, os estudantes fazem o experimento e escrevem sobre ele para aprenderem sobre os gases e suas propriedades (ou mostrarem que aprenderam). Parece-nos que as crianças-escritoras esperam interagir com a professora-leitora e mostrar para ela, na interação, que aprenderam esse conteúdo 
através da experimentação. Dessa forma, afirmamos que os objetivos da escrita e da realização da experimentação são diferentes, mas se relacionam.

Após discutir o objetivo da atividade, a professora segue descrevendo como será o experimento. Nesse momento, realiza com os alunos o levantamento de hipóteses sobre o que eles acham que vai acontecer ("Se o gás carbônico for igual ao gás oxigênio, a chama vai ficar acesa ou vai apagar?" e "Se ele for igual ao oxigênio, ou seja, se ele for um gás comburente, a chama vai ficar acesa. Mas e se ele não for, o que vocês acham que vai acontecer?"). A construção de hipóteses com os alunos no desenvolvimento de aulas com experimentação pode tornar essas mais ricas, ao possibilitarem a geração de questionamentos nos alunos, confrontando as ideias que possuem sobre um fenômeno com o acontecimento empírico (MARANDINO et al, 2009). Em relação à articulação com atividades de leitura e escrita, ao mobilizar reflexões sobre o que pensam que irá acontecer, a professora ativa conhecimentos de mundo, que serão necessários para que possam escrever sobre isso. Ativa também conhecimentos linguísticos ao trazer termos do campo lexical científico para o diálogo (gás carbônico, gás oxigênio e comburente).

O conteúdo abordado na experimentação, que aparece no diálogo sobre os objetivos e levantamento de hipóteses, mostra que, em relação às finalidades do ensino de Ciências discutidas por Goodson, esta se encontrava em uma tradição curricular acadêmica, pois se relaciona com as ciências de referência da disciplina escolar, nesse caso, as propriedades dos gases, estudadas pela Química. Porém, analisando a experimentação como uma metodologia ativa de aprendizagem, podemos associá-la também a finalidades pedagógicas e até mesmo a finalidades utilitárias, visto que entendemos que essa atividade pode ajudar no desenvolvimento da leitura e da escrita.

A professora continuou a aula com a realização do experimento. Ela o fez três vezes na sua mesa, de forma que cada vez uma parte pequena da turma pudesse observar e participar da discussão.

\footnotetext{
“- A professora chama uma parte da turma para olhá-la fazer o experimento na mesa. Depois chama outra parte.

Discute o resultado do experimento.

Professora: Apagou a vela, não apagou? Olha, queimou o palito um pouco e apagou. Agora vem o resto ver. Vou fazer mais uma vez.

Professora: Acabou a reação. Vou botar mais vinagre.
} 
Aluno A: Apagou!!!

Professora: Vamos responder agora. Peraí.

- Professora, repete o experimento pela terceira vez, para alunos que ainda não tinham visto.

Estudante A: E se não tivesse gás carbônico?

Professora: Peraí vou acender!" (Notas do diário de campo e transcrição de audiogravação)

Os estudantes interagem com o experimento (“Apagou!!!) e se envolvem com a atividade. Como discutimos, é a partir dessa vivência que poderão escrever depois, criando sentido ao que experimentaram, produzindo linguagem escrita. Depois do experimento, a professora e os alunos começam a responder à pergunta escrita.

“- Discutem oralmente a pergunta do caderno sobre o experimento.

Professora: O gás carbônico é um gás comburente?

Estudantes.: Não!!!

Professora: Por que não?

Estudante B: Porque o fogo apagou.

Professora: O fogo apagou

Estudante C: Que? Fala de novo!

Professora: O gás carbônico é um gás comburente?

Estudantes.: Não!!!

Professora: Por que não?

Estudante D: Porque não tem o oxigênio.

Professora: Por que apagou a chama, apagou o fogo. Não, porque o fogo apagou.

- A professora espera os estudantes escreverem". (Notas do diário de campo e transcrição de audiogravação)

Percebemos aspectos importantes do dialogismo que se estabelece através da atividade de experimentação. A professora busca trazer as vozes dos alunos, fazendo perguntas para que se coloquem na interação, ao longo do experimento e depois na reflexão dos resultados, como vemos nas seguintes perguntas:

- E a gente via que quando fechava a vela com copo de vidro, o que acontecia com a chama da vela? (...) Por que apagava?

- Lembram desse nome?

- Vocês lembram que a gente fez o vulcão? (...) Vocês lembram que o vulcão entrava em erupção? 
- A reação do vinagre com o bicarbonato solta qual gás? (...) Então eu vou criar um ambiente aqui que tenha gás?

- Se o gás carbônico for igual ao gás oxigênio, a chama vai ficar acesa ou vai apagar?

- Mas e se ele não for, o que vocês acham que vai acontecer?

- E se não tivesse gás carbônico?

- O gás carbônico é um gás comburente? (...) Por que não?

O dialogismo marca a interação entre a professora, os estudantes, a experimentação, aulas anteriores e o texto escrito que irão produzir depois. Os próprios estudantes impõem sua participação no diálogo ao fazerem questionamentos ("O que tá escrito ali professora?" e "E se não tivesse gás carbônico?") e ao responderem de forma diferente do que a professora esperava (“Porque não tem o oxigênio."). Assim, o diálogo vai se estabelecendo em torno da realização do experimento e junto com ele, ao final, atividades de escrita são propostas. Essas atividades partem do que os estudantes observaram e do que discutiram na interação social com a professora e com o experimento. Nesse diálogo, gêneros discursivos se articulam. Gêneros secundários mais complexos, marcados pelo uso dos termos científicos gás carbônico e gás comburente colocados na pergunta (“O gás carbônico é um gás comburente? Por que?") e depois utilizados nas discussões posteriores, e gêneros primários mais simples com os quais descrevem o que observaram ("Porque o fogo apagou").

A atividade escrita elaborada contém apenas uma pergunta. É uma pergunta abstrata, que envolve características da linguagem científica, como signos do campo lexical científico (gás carbônico e gás comburente). Porém, os estudantes parecem ter compreendido e conseguiram respondê-la, depois da interação com a professora ao longo de toda a atividade de experimentação, isto é, após a discussão da pergunta, o levantamento de hipóteses, a realização e observação do experimento e então o diálogo sobre o que perceberam. Todas essas etapas contribuíram para a ativação dos sistemas de conhecimento necessários para produção escrita. Ao final, a discussão da pergunta em si, estimulou a mobilização de estratégias para o desenvolvimento da atividade de escrita (de revisão constante, reescrita, etc.). A partir do tipo de pergunta construída e a resposta dos alunos, propomos uma reflexão sobre a interseção entre o letramento científico e o letramento linguístico em geral. Defendemos que ao realizarmos o letramento científico, utilizando 
linguagem científica e elaboração de raciocínio relacionados à construção do conhecimento científico, acabamos por acionar também conhecimentos necessários para o processo de escrita, como vimos na interação entre os estudantes, a professora, a experimentação e a produção textual final.

Por fim, destacamos que a pergunta não estimula a produção autoral escrita. Ela possibilita alguma autoria, especialmente na resposta da justificativa para a questão ("Por que?"). Porém, mesmo que a resposta final que a professora desenvolveu seja construída a partir do que os alunos trouxeram ("Não, porque o fogo apagou."), não há um incentivo ao aparecimento da individualidade do enunciador e nem para a criação de sentidos diversos, devido à maneira que a demanda é colocada.

A análise de observações de outras aulas com experimentos possibilitou também reflexões sobre possíveis articulações entre atividades de experimentação e processos de ensino-aprendizagem de leitura e, especialmente, de escrita. A atividade que apresentamos a seguir, foi realizada no laboratório de Ciências da escola. Foi uma atividade de experimentação proposta por uma aluna de licenciatura em Ciências Biológicas que fazia estágio supervisionado na escola. O objetivo da atividade era a montagem de terrários para reflexões sobre conhecimentos ecológicos que estavam estudando nas aulas de Ciências, que se referiam ao funcionamento dos ecossistemas. Diferente da primeira aula que discutimos, essa aula não foi demonstrativa, cada grupo de estudantes montou seu próprio terrário. O dia começou com o deslocamento da turma da sala de aula para o laboratório de Ciências. As crianças gostaram de ir para o laboratório, como mostra o trecho abaixo, transcrito do diário de campo:

\footnotetext{
“- Está chovendo muito. Hoje é aula prática no laboratório de ciências da escola. Quem dará aula será a licencianda. Vieram poucas crianças (talvez seja por causa da chuva). Fomos para o laboratório. As crianças parecem felizes de ir para o laboratório. Quando a professora disse que a aula seria no laboratório, elas comemoraram. As crianças chegaram no laboratório e sentaram em grupo. Eram quatro mesas." (Notas do diário de campo).
}

Primeiramente, destacamos o envolvimento dos alunos com a possibilidade de irem para o laboratório vivenciarem uma atividade de experimentação. A felicidade dos estudantes ao se deslocarem para o laboratório mostra novamente o elemento motivacional e afetivo das atividades experimentais, ainda mais quando realizadas no laboratório, que funciona como um espaço especial das aulas de 
Ciências. Nesse atividade que destacamos, ir ao laboratório da escola foi um acontecimento importante para os alunos e, como colocaram em suas falas nas entrevistas, mostrou como gostam desse tipo de aula. Acreditamos que esse aspecto motivacional, relacionado à experimentação e à ida ao laboratório da escola, pode influenciar também nos processos de leitura e de escrita, visto que os realizarão com maior envolvimento emocional. Marandino (2018) recupera uma discussão de Weissmann (1998 apud MARANDINO, 2018) e reflete sobre como o espaço físico da escola se relaciona com seu projeto pedagógico. Pensando no laboratório de Ciências, coloca que a presença ou ausência desse espaço e o tipo de mobiliário e equipamento que possui, falam da importância dada às ciências naturais no currículo escolar (na atualidade ou historicamente) e da abordagem didática que lhes é dada. O laboratório dessa escola onde a atividade descrita foi realizada era em uma sala grande, em frente ao pátio da escola, limpo, organizado e com equipamentos novos, como um modelo de corpo humano e vidraria. A professora, em uma conversa informal, me contou que tinha conseguido o apoio da direção com recursos para o laboratório e para limpeza e organização, de forma a poder utilizálo com maior frequência nas aulas de Ciências. A própria professora, inclusive, tinha organizado uma oficina de formação continuada para professores da sua escola sobre experimentação didática e o uso do laboratório escolar em processos de ensino-aprendizagem de Ciências, articulada a um projeto de extensão do Projeto Fundão-Biologia/ UFRJ, como colocamos anteriormente. Tudo isso nos mostra como a experimentação era valorizada na escola, principalmente, por essa professora e as aulas que desenvolvia.

Após se organizarem no laboratório para a atividade de experimentação, as crianças receberam um roteiro escrito sobre a prática, desenvolvido pela licencianda, com supervisão da professora. Na primeira página do roteiro há uma breve descrição do que é um terrário, os objetivos da experiência, uma lista dos materiais e o procedimento para montagem. Na parte de trás, há três perguntas para reflexão sobre o que fizeram e um esquema ilustrativo de um terrário (FIGURA 16): 


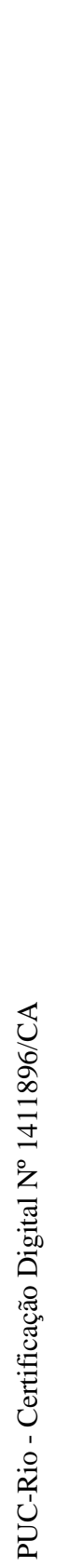

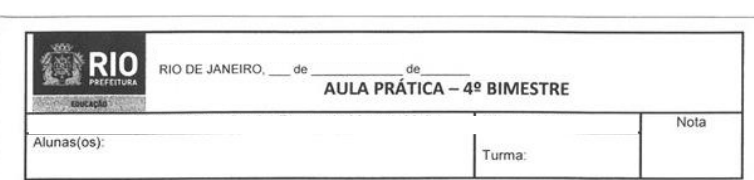

Você sabe o que é um Terrário A melhor representaçáo de um ambiente natural é o terrário. Ele pode representar tanto um ecossistema
terrestre quanto aquático, na aula de hoje faremos um terrário terrestre. Nele, após alguns dias e possive absevar tanto o ciclo da agua quanto o das plantas.

Objetivos

Revisăo da matéria sobre ecossistema, ciclo da àgua e ciclo atmosférico.

Materiais necessários
- Garrafa pet

- Carvăo ativa

- Terra adubado

Cascalho

- Papel insulfilme

Procedimento

Passo um: Adicionar cascalho (pedras):

Passo dois: Adicionar Areia

Passo Três: Adicionar Carvão:

Passo quatro: Adicionar Terra adubada:

Passo cinco: Adicionar água até molhar toda a terra;

Passo seis: Plantar a semente ou a planta:

Passo sete: Molhar novamente, dessa vez somente um pouco

Passo oito: Vedar a garrafa pet com papel insulfilme;

FIGURA 16: Roteiro escrito utilizado em atividade de experimentação para montagem de um terrário.

Depois de entregar o roteiro, a professora falou brevemente sobre ele e
De acordo com o que você observou, responda:

1) Agora que já vimos que um Terrário é a representação de um pequeno ecossistema. Dê um exemplo de (1) A

2) Ao final da montagem do terrário, foi necessário tampá-lo com papel insulfilme. Qual o objetivo des 2

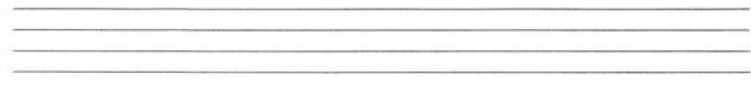

3) Lembrando-se do ciclo da àgua, no qual a água sofre evaporaçăo da superficie de rio, oceanos, lagos,

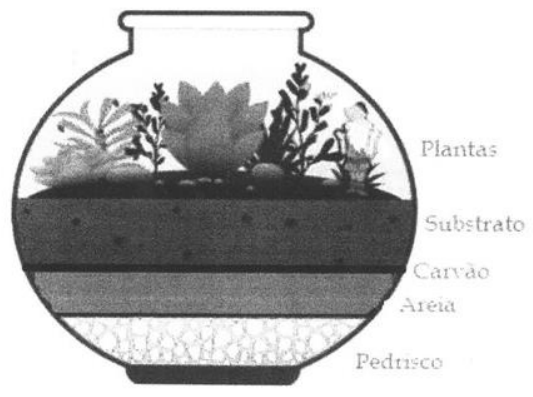
conferiu com os alunos a lista de materiais que aparecia escrita no roteiro.

“- A Professora distribuiu o roteiro de aula prática. É um roteiro escrito, desenvolvido pela licencianda. Distribuiu um roteiro por grupo de alunos em cada mesa. A professora começa a prática explicando sobre o roteiro.

Professora. Em cima da mesa de vocês tem um roteiro com três perguntas. Todo mundo vai ter que responder hoje. Mas só no final. Primeiro vamos fazer tudo.

- Depois a professora conferiu os materiais junto com eles. Ela vai lendo os material

is no roteiro e pedindo para os alunos verem se tem na mesa deles.

Professora: Vamos conferir os materiais, garrafa pet. Todo mundo tem?

Estudante A: Tem

Estudante B: Tem

Professora: Carvão, todo mundo tem?

Estudantes: Siiim (...)

Professora: Areia, aquela branquinha

Estudante C: Confere

Estudante D: Confere (...)" (Notas do diário de campo e transcrições de audiogravação) 
Ao colocar que os alunos possuem um roteiro, que depois deverá ser respondido de forma escrita, a professora mobiliza reflexões sobre o objetivo da escrita. Devem escrever sobre o que vão fazer e observar. Assim, ativa conhecimentos interacionais importantes para produção textual, pensamentos sobre o porquê escrevo e para quem escrevo. Ao ler os materiais do roteiro junto com os alunos, estimula a interação entre ela, os estudantes, a prática, os materiais que utilizarão e o próprio texto do roteiro.

No próximo momento da aula, a professora dialoga com a turma sobre o objetivo da experimentação, trazendo o conceito de ecossistema para a interação. Ela não lê a parte inicial do roteiro que descreve os objetivos da montagem do terrário em um texto escrito, mas discute essa questão oralmente.

“- Depois de conferir os materiais, a professora começa a discutir o conceito de ecossistema. Diz que na aula de hoje o que vão fazer é montar um ecossistema.

Professora: O que a gente vai fazer? A gente vai montar dentro dessas garrafinhas que vocês receberam um modelo de ecossistema terrestre. $\mathrm{O}$ que é um ecossistema terrestre? (...) O que é um ecossistema? A gente aprendeu na aula passada.

Estudante A: É...

Estudante B: Deu branco

Professora: Tá. A Ingrid explicou mais ou menos o que é... Disse que é uma mistura de seres vivos e não vivos. É mais ou menos por aí. Ecossistema é um lugar onde fatores bióticos e abióticos se relacionam. O que que é fator biótico? O que que é uma coisa biótica?

Estudante C: Biótico...

Estudante D: É coisas vivas!

Professora: Coisas vivas. O que que é abiótico?

Estudante D: Coisas não vivas

Estudante E: Coisas mortas

Professora: Coisas não vivas. Então galera, se é um lugar onde coisas vivas e coisas não vivas se relacionam, então a gente vai montar dentro dessa garrafinha aqui um ecossistema bem pequenininho. Porque em uma garrafinha pequena a gente vai conseguir montar um ecossistema pequeno. Para ser ecossistema tem que ter alguma coisa viva?

Estudantes: Sim

(...)

Professora: Quem acha que sim levanta a mão. Quem acha que não? Pessoal, para ser ecossistema tem que ter ser vivo. Se não tiver ser vivo eu não posso chamar de ecossistema. Se tiver só fator abiótico eu não posso chamar de ecossistema, tem que ter ser vivo. Na mesa aí de vocês, de materiais, tem algum ser vivo?

Estudante A: Tem

Estudante B: Tem 
Estudante C: Uma planta

Professora: Quem é o ser vivo?

Estudante F: A planta

Estudante C: O Coentro

Professora: A planta é o ser vivo. Essa plantinha aqui que vocês receberam. (...) Então todo mundo já lembrou o que é um fator biótico, ser vivo e o que que é um fator abiótico, ser não vivo e o que que é um ecossistema. Responde aí então, Laísa o que que é um ecossistema?

Estudante B: Tudo que é vivo.

Professora: Tudo que é vivo é? Quem sabe tudo que é vivo? Bio...

Estudante C: Biosfera

Professora: Biosfera é tudo que é vivo na Terra. Ecossistema não é tudo que é vivo. E aí, quem sabe explicar o que é ecossistema?

Estudante G: É coisas vivas e não vivas

Professora: Um lugar onde coisas vivas e não vivas estão se relacionando e dependem uma da outra. Eu posso chamar um laguinho de ecossistema?

Estudantes: Sim!

P: Depende. Depende do que? Se tiver ser vivo ali dentro aí eu posso chamar de ecossistema. Se for uma poça d'água que a chuva fez e não tiver nada ali eu não posso chamar de ecossistema é só uma poça d'água. Agora, se for um laguinho que tem peixinho, que tem alga, que tem ser vivo ali. Mesmo que seja um ser vivo microscópico eu já posso chamar de ecossistema" (Notas do diário de campo e transcrição de audiogravação)

Nesse trecho, vemos que a professora coloca o objetivo da experimentação ("O que a gente vai fazer? A gente vai montar dentro dessas garrafinhas que vocês receberam um modelo de ecossistema terrestre"), ativando conhecimentos para que os estudantes pensem na interação que vivenciarão na experimentação e ativem conhecimentos sobre os objetivos do que escreverão depois. Em articulação à colocação sobre o roteiro, a explicitação dos objetivos da aula contribui para que ativem conhecimentos interacionais, envolvidos na reflexão sobre os objetivos do texto que o produtor precisa acionar para escrever. A partir da colocação do objetivo da experimentação, a professora traz as vozes dos alunos para o diálogo, discutindo o conceito de ecossistema.

Percebemos nesse diálogo que também essa atividade de experimentação se encontra em uma tradição curricular acadêmica, em uma perspectiva de Goodson, visto que se associa aos conhecimentos científicos da ciência Ecologia. Mas, esta pode se articular também a tradições pedagógicas e utilitárias, relacionadas às metodologias ativas de aprendizagem, desenvolvimento de habilidades para trabalhar em grupo, desenvolvimento da escrita, etc. 
Ao trazer as vozes dos alunos, a professora estimula a interação entre os estudantes e a atividade. Para isso, a professora constrói diversas perguntas, estimulando-os a se colocarem no diálogo:

\footnotetext{
- O que é um ecossistema terrestre? (...) O que é um ecossistema? A gente aprendeu na aula passada.

- O que que é fator biótico? O que que é uma coisa biótica?

- O que que é abiótico?

- Para ser ecossistema tem que ter alguma coisa viva? (...) Na mesa aí de vocês, de materiais, tem algum ser vivo? (...) Quem é o ser vivo?

- E aí, quem sabe explicar o que é ecossistema?

- Eu posso chamar um laguinho de ecossistema?
}

A análise dessas perguntas mostra que na aula se estabelece, na perspectiva bakhtiniana, um diálogo que marca a interação social entre a professora, os estudantes, aulas anteriores, os conceitos enunciados e a própria experimentação, quando estimula que olhem para os materiais e relacionem com o que discutiam (“Na mesa aí de vocês, de materiais, tem algum ser vivo?”). O dialogismo que marca esse momento da aula é importante para que os estudantes possam se colocar na interação e, a partir dela, possam produzir textos escritos sobre o que vivenciaram, reforçando o que discutimos anteriormente. Nesse trecho, percebemos também que a professora, ao discutir conceitos e conteúdos que vinham trabalhando nas aulas de ciências, mobiliza sistemas de conhecimento de mundo e de conhecimento linguístico, relacionados ao que compreendem como ecossistema, fatores bióticos e abióticos, etc. Esses sistemas precisam ser ativados para que possam ler o roteiro, construindo sentidos para as perguntas escritas ali colocadas, e para que depois possam escrever respostas a elas, produzindo textos escritos.

Depois dessa discussão, a professora passa a palavra para a licencianda, que começa a montar o terrário junto com os alunos, seguindo as etapas do procedimento descrito no roteiro:

“- Professora passa a palavra para a licencianda.

Professora: Então a Fernanda vai assumir e vai explicar para vocês como é que a gente vai montar esse ecossistema. Ela vai assumir e montar o terrário com vocês.

- Sem ler o roteiro, a licencianda explica que eles devem formar uma camada com as pedras no fundo do terrário. Os alunos parecem bastante interessados e envolvidos com a atividade. 
Licencianda: Todo mundo pegou as pedrinhas não pegou? A primeira etapa do terrário é as pedrinhas. A gente vai colocar elas bem no fundo aqui, ó. (A licencianda coloca pedras no fundo da garrafa pet que está na sua mesa).

- A licencianda chama atenção para o desenho que está no roteiro (uma ilustração de um terrário montado com suas diferentes camadas).

Licencianda: Gente, gente. Olhando aqui o desenho porque vocês acham que a gente está colocando a pedra no fundo?

Estudante A: Pra descer a água...

Licencianda: Pra quê?

Estudante B: Para reter a água

Licencianda: Isso. A água vai descer e acumular aqui nas pedras, no espaço entre as pedras. Por isso que a gente coloca a pedra no fundo. (...) Se vocês pegarem as pedrinhas elas são bem grandes. Aí fica um espaço entre elas. Ali que a água vai ficar acumulada.

- Depois, ela manda colocar areia.

Licencianda: Agora, qual é a próxima etapa. Tem uma terrinha branca aí?

Estudante C: Tem. Areia.

Licencianda: Então areia. Você vê a diferença entre pedra e areia? A areia é bem fininha (mostra com as mãos mexendo na pedra e na areia). Então, joguem areia aí para ver como é que fica. (...)

Licencianda: Vocês viram que formou duas camadas? Uma aqui e, mesmo que tenha entrado um pouquinho, uma camada de pedra e uma de areia. Agora para que vocês acham que serve a areia?

Estudante D: Para absor...

Licencianda: Ali na praia, você vê que a água quando vem...

Estudante D: Absorve!

Licencianda: Ela absorve bastante água.

Estudante B: Então é pra absorção?

Licencianda: É para absorção e ela também mantém a água ali.

(...)

Licencianda: A água vai acumular aqui embaixo, para ela acumular aqui embaixo ela precisa passar por aqui. Pela terra...

Estudante B: Pelo carvão!

Licencianda: Pelo carvão e pela areia. A areia ajuda a infiltração e a água a acumular aqui embaixo". (Notas do diário de campo e transcrições de audiogravação)

Nesse momento da aula, a licencianda começa a participar mais do diálogo, a partir do roteiro e do planejamento de aula que desenvolveu. Marandino et al (2009) discutem que é muito comum os licenciandos, nas atividades de estágio supervisionado dos cursos de formação inicial de professores, realizarem atividades experimentais com os alunos da escola. Colocam que nesse processo, os licenciandos produzem novos materiais didáticos para o acervo da escola (como o 
roteiro do terrário que a licencianda desenvolveu), introduzem os alunos em práticas científicas e contribuem para atenuar algumas das dificuldades para realização destas atividades. Destacam que a experimentação como atividade do estágio supervisionado contribui para interação entre diferentes contextos e sujeitos, entre instituições universitárias e escolares e entre professores experientes e novatos. Os licenciandos trazem para escola experiências de atividades científicas vividas na formação universitária e estimulam a realização de atividades experimentais com maior frequência. Os professores da escola, por sua vez, modulam essas atividades, revestindo-as de características próprias da escola, ajustando os materiais, procedimentos e linguagem para torná-los mais apropriados aos interesses e faixa etária dos alunos. Vemos que na aula observada os alunos interagem com a licencianda, que traz novos elementos com a atividade de experimentação e contribui também com os processos de ensino-aprendizagem de leitura e escrita.

A licencianda estabelece um diálogo com os alunos durante a experimentação, fazendo perguntas para que coloquem suas vozes nesse diálogo, talvez influenciada pela professora, visto que está em processo de formação docente. Ela vai conversando com os alunos e ao mesmo tempo ajudando-os a montarem seus terrários. Nesse processo, tenta construir com eles algum sentido ao que estão fazendo, trazendo reflexões sobre as características do solo (como, por exemplo, "Vocês viram que formou duas camadas? Uma aqui e, mesmo que tenha entrado um pouquinho, uma camada de pedra e uma de areia. Agora para que vocês acham que serve a areia?). Ela traz elementos cotidianos do gênero primário do discurso para o diálogo, por exemplo, quando comenta em relação à absorção da água pelo solo: “Ali na praia, você vê que a água quando vem...”. Dessa forma, mescla gêneros primários com elementos de gêneros discursivos secundários, contribuindo para que os estudantes construam sentido para questões abstratas. Ao fazer isso, atua na ativação dos sistemas de conhecimento de mundo e linguístico dos estudantes, que refletem sobre solos, tamanho dos grãos, relação com a água, etc. Esses sistemas serão utilizados depois para produção escrita. Os alunos participam da interação proposta e mostram que estão mobilizando seus conhecimentos com seus comentários. Um dos alunos fala do carvão e relaciona com o que estavam discutindo, para isso, ele lê a imagem do roteiro, mesmo que a licencianda ainda não tenha mencionado esse material. 
Depois disso, a professora atua mais fortemente na ativação dos sistemas de conhecimento relacionados ao conhecimento de mundo e linguístico do campo lexical relacionado aos estudos do solo. Ela entra na interação novamente trazendo sua voz para o diálogo com os estudantes sobre as diferenças entre os grãos que formam o solo.

“- A licencianda e a professora constroem uma comparação entre os grãos do solo (pedra, terra e areia). Tamanho dos grãos e capacidade de acumular água. (...)

Licencianda: Mas, vocês veem como as partículas são diferentes? A areia é mais fininha e melhor para absorver, enquanto a pedra é meio brusca e meio dura.

Professora: Pessoal, faz o seguinte, pega um grãozinho de areia, pega um grãozinho de areia. A pedrinha já tá lá dentro e não tem como ver mais. Pega o grãozinho de areia, agora pega o grãozinho de terra. Pegaram? Põe na mão aí de vocês, pode colocar em cima do azulejo para todo mundo ver grãozinho de areia, grãozinho de terra e agora pega a pedrinha. Pega a pedrinha. Isso. Pessoal, qual dos três grãos é maior?

Estudantes: A pedra.

P: Qual dos três grãos é menor?

(...)

Professora: Então vamos pensar assim, um potinho cheio de pedra e jogar água dentro. A água vai ficar em cima ou a água vai ficar embaixo?

Estudante E: Embaixo.

Professora: Embaixo, por quê?

Estudante F: Porque vai absorver.

Professora: Ela vai passar por onde?

Estudante G: Vai filtrar.

Professora: Tem espaço entre os grãos e aí ela vai passar. (...). Quanto maior o grão, mais espaço entre os grãos eu vou ter. Então a água vai infiltrar mais. Agora a areia. Vou colocar um monte de grãozinho de areia um do lado do outro e aí vou colocar um monte de grãozinho de terra. Vai ter mais espaço entre os grãozinhos de areia ou entre os grãozinhos de terra?

Estudante H: Areia

(...)

Professora: Quando a gente vai na praia, o mar vem e molha a areia. O que acontece com a água? Ela fica boiando ali na areia?

Estudante A: Não

Professora: O que que acontece? Ela vai?

Estudante B: Infiltrar?

Professora: Infiltrar na areia. Porque que isso acontece? (...). Porque há espaço entre os grãos de areia. Tem espaço entre os grãos de areia. (...). E se for no mar, o mar vai molhar a areia depois volta e a água se infiltra lá para baixo. Agora e na terra? Quando chove na terra, rapidinho molha, 
igual a areia, ou fica laminha? (...) Tão entendendo o que que a gente está fazendo?

Estudante D: Estamos

Professora: A gente tá colocando grãos cada vez maiores para acontecer o que?

Estudante E: Descer

Professora: A água infiltrar e poder ficar lá e embaixo (...)” (Notas de diário de campo e transcrição de audiogravação)

Nesse diálogo, percebemos que a professora tenta concretizar os conceitos que estavam discutindo em relação à formação do solo. Assim, pede para os estudantes pegarem os grãos e compararem, sentindo-os com as mãos. Essa concretização é importante para que deem sentido à discussão colocada, ao que leem no roteiro e ao que estão fazendo na montagem do terrário. Para contribuir, ela traz elementos do cotidiano, aproveitando a ideia da areia da praia que a licencianda colocou anteriormente e criando situações imaginativas com elementos que os alunos conhecem ("Então vamos pensar assim, um potinho cheio de pedra e jogar água dentro. A água vai ficar em cima ou a água vai ficar embaixo?” e "Agora e na terra? Quando chove na terra, rapidinho molha, igual a areia, ou fica laminha?"). É importante que deem sentido ao que estão fazendo e ao que estão lendo, para que possam depois escrever sobre isso.

A licencianda e a professora seguem montando o terrário com os alunos, dialogando sobre cada etapa do procedimento, especialmente sobre o objetivo daquele procedimento para manutenção das plantas. Nesse processo vão trazendo as vozes dos alunos, que interagem com a prática e mobilizam seus conhecimentos.

"Depois da discussão, a licencianda continua montando as camadas do terrário. Agora pede para eles botarem o carvão e discute por que o carvão é importante.

(...)

Licencianda: Depois do carvão a gente vai colocar o que?

(...)

Licencianda: Pessoal, atenção. Presta atenção. Agora que a gente colocou a terra, antes de plantar a gente tem que o que? Colocar a água. Para que a gente precisa molhar?

(...)

Estudante A: Pra ficar molhado!

Estudante C: Pra planta não morrer! Não morrer...

Licencianda: Então a gente vai botar bastante água agora e depois tem que colocar mais água. 
Professora: Porque que a planta precisa de água para não morrer? Para que que ela usa a água? Pra fazer....

Estudante E: A fotossíntese!

(...)

Licencianda: Agora a gente tem as plantas e as sementes. Eu quero que vocês escolham se querem colocar as duas ou uma só.

- Todos os grupos decidem colocar todas as plantas. Começam a plantar. A Professora e a licencianda circulam pelos grupos e vão ajudando. Os alunos têm dúvidas sobre a montagem e discutem com colegas do próprio grupo". (Notas do diário de campo e transcrições de audiogravação).

Depois da montagem do terrário, chega o momento de toda essa vivência ser utilizada para interação através da produção textual, na leitura e resposta escrita às perguntas do roteiro. Dessa forma, os estudantes refletem sobre o que vieram discutindo e experimentando, aprendendo conteúdos relacionados ao ensino de ciências, e ao mesmo tempo, mobilizando aspectos referentes aos processos de leitura e de escrita. A primeira pergunta demanda apenas que citem exemplos. As crianças dão sentido à pergunta e produzem a resposta com facilidade. A autoria da produção textual aparece na escolha dos exemplos, que varia entre os estudantes.

“- Após verificar e ajudar a organizar as mesas, a licencianda pede para eles pegarem o estudo dirigido e lerem a primeira pergunta.

Licencianda: Estudo dirigido todo mundo. Tem perguntas atrás. Eu quero que vocês leiam para mim. Qualquer um, lê pra mim.

- As crianças brigam para resolver quem vai ler em voz alta. Vários alunos diferentes querem ler. A professora intervém e manda cada um ler uma questão.

(...)

Estudante A lê: Agora que já vimos que um terrário é a representação de um pequeno ecossistema. Dê um exemplo de fator biótico e abiótico que pode ser observado no terrário.

- Após o aluno ler, a licencianda discute com a turma a resposta. Os alunos estão dispersos. Há apenas um roteiro por grupo. Só um aluno de cada grupo escreve no roteiro, o resto fica a parte no momento da escrita. Depois de discutir, a licencianda espera eles escreverem. Eles discutem a questão um com facilidade.

Licencianda: Qual é o fator biótico?

Estudante B: Planta, pedra...

Estudante C: A planta

Licencianda: A planta. E abiótico?

Estudante D: Garrafa, carvão, areia

Estudante C: Pedra

Licencianda: Areia, pedra...

(...)" (Notas do diário de campo e transcrições de audiogravação) 
Depois dessa pergunta, a licencianda segue para a segunda questão. Essa parece mais complicada para os estudantes. Assim, a licencianda e a professora precisam dialogar mais sobre o que está sendo solicitado na pergunta, buscando mediar a construção de sentido para a pergunta e para a produção textual exigida.

“- Uma aluna lê a questão 2. Depois a licencianda tenta discutir a resposta. Ela os ajuda a começar a pensar. A professora intervém e ajuda a construir um raciocínio sobre o ciclo da água e sobre o ar (oxigênio e gás carbônico no terrário).

Licencianda: Pronto gente, agora eu quero que alguém leia a número 2

(...)

Estudante B lê: Ao final da montagem do terrário, foi necessário tampá-lo com o papel insulfilme. Qual é o objetivo desse procedimento? Você acha que isso afeta a vida dos seres vivos dentro do terrário? De que modo?

Licencianda: Então, qual foi o objetivo? O que que ele fez com o terrário? Porque que a gente fez o terrário?

Estudante G: Porque vai...

Estudante A: Para nascer o coentro.

Estudante B: Vai nascer feijão!

Licencianda: Para quê?

Estudante C: Para ver as plantas nascendo.

Licencianda: Também.

Estudante F: Para ver o biótico e o abiótico.

Licencianda: E o que mais?

Estudante A: Ecossistema.

Licencianda: Para ver como funciona um ecossistema. (...)

Professora: Pessoal, no final a gente vai fechar isso aqui. Se a gente pegar e fechar isso aqui, lacrar, a planta vai sobreviver?

Estudante A: Não

(...)

Estudante C: Sim

(...)

Professora: Se a gente lacrar, vedar completamente?

(...)

Professora: O que que a planta precisa para sobreviver?

Estudante A: Ar

Estudante B: Água!

Estudante D: Luz

Estudante C: Água

Professora: O que mais? Água, luz, ar. O Que mais? Do que que ela precisa do ar?

Estudante A: Ar 
Professora: Do que que ela precisa do ar?

Estudante F: Gás carbônico

Professora: Gás carbônico. Se a gente fechar tudo aqui ela vai ter o que ela precisa?

Estudante B: Não.

Professora: Ela vai ter luz?

Estudante A: Vai

Professora: Ela vai ter gás carbônico?

(...)

Professora: Ela vai ter água? Sim ou não?

Estudantes: Sim

Professora: Então tá, vamos começar pela luz, isso aqui tá impedindo a luz de entrar?

Estudante A: Não

Professora: Se eu colocar um papel transparente vai impedir a luz de entrar? Estudantes: Não

(...)

Professora: Agora, a água que a gente colocou aqui dentro, o que que vai acontecer com ela se eu deixar aberto?

Estudante C: Vai evaporar

(...)

Professora: Vai evaporar. O que que vai acontecer com o vapor da água?

Estudante E: Vai...

Estudante F: Vai formar uma...

Estudante B: Qual é o nome?

Professora: Vai embora, né? Tá aberto, vai para atmosfera. Agora, se eu lacrar isso aqui o que que acontece? O que que vai acontecer?

Estudante F: Vai ficar tipo que pingando

Professora: Então já sabemos que alguma coisa vai acontecer. A água vai acabar se eu fechar aqui?

Estudante B: Não

Professora: Porque que não vai acabar?

Estudante I: Porque...

Estudante C: Porque vai ficar igual um pinga pinga

Professora: Isso é o que? Que a gente aprendeu no terceiro bimestre...

Estudante J: A fotossíntese!

Professora: Qual é o nome disso aqui? (Mostra água condensada em um pote no laboratório)

Estudante B: Condensação

Estudante G: Que condensação?

Professora: Gente isso aqui é o que da água?

Estudante B: Condensação! 
Licencianda: É o ciclo da...

Estudante I: Da água!

Professora: (...) O ciclo da água! Vai acontecer o ciclo da água, literalmente, porque o vapor de água que evaporar não vai para atmosfera, ele fica preso aqui dentro e vai, como a Geovana disse, vai condensar e vai cair de volta na terra, certo? Então, água não vai acabar ali dentro? Não.

Professora: E o ar gente? O que vai acontecer? Se eu colocar, por exemplo, uma minhoquinha dentro desse lugar fechado vai acontecer o que?

Estudante A: Vai morrer

Estudante B: Não vai não

Estudante C: Vai morrer

Professora: A gente já sabe o que a planta precisa para sobreviver, agora o que a minhoca precisa para sobreviver?

Estudante D: Terra

Professora: Que mais?

Estudante E: Água

Estudante F: Ar

Estudante G: Luz

Professora: Qual tipo de ar que ela precisa?

Estudante C: Oxigênio

Professora: Oxigênio e o que mais? Água. Todo ser vivo precisa de água. Ela vai ter oxigênio se eu fechar e lacrar tudo aqui dentro?

Estudante G: Não, professora

- Uma aluna consegue relacionar a fotossíntese com a produção de oxigênio e a sobrevivência das minhocas.

Estudante J: Professora, se tiver uma planta....

Professora: Pera aí, pera aí. Vamos escutar a resposta da Thaís, silêncio. Responde.

Estudante J: Se tiver uma planta junto com ela, ela vai sobreviver. Agora, se não tiver ela morre.

Professora: Porque que com a planta ela sobrevive?

Estudante J: Porque se a planta fazer a fotossíntese vai soltar oxigênio.

- Toda turma bate palma.

Professora: A planta faz fotossíntese, então a planta vai produzir oxigênio. O que que a planta precisa para a fotossíntese? Já me falaram gás carbônico mais o que?

Estudante A: Oxigênio

Professora: O que que a planta precisa para fazer a fotossíntese? Gás carbônico...

Estudante B: Raios solares

Professora: Luz e mais o que?

Estudante C: Água

Professora: Água (...) Mais o que? O que que ela faz?

Estudante E: Fotossíntese! 
Professora: Oxigênio e mais o alimento dela

Estudante E: Ah! Eu falei!

Professora: Então se a planta produz o oxigênio a planta consegue sobreviver.

Estudante L: Aí faz açúcar para gente comer!” (Notas do diário de campo e transcrições de audiogravação)

Destacamos, inicialmente, a dificuldade que tiveram para construir um sentido na leitura da pergunta e na elaboração da resposta. Isso pode ter acontecido devido à complexidade da pergunta, que envolvia na verdade três questões em uma pergunta (“Ao final da montagem do terrário, foi necessário tampá-lo com o papel insulfilme. 1) Qual é o objetivo desse procedimento? 2) Você acha que isso afeta a vida dos seres vivos dentro do terrário? 3) De que modo?"). A aluna conseguiu ler a pergunta em voz alta com tranquilidade, mas não dar um sentido ao que lia, o que reforça o pressuposto de que a leitura não é simplesmente decifrar um código, mas envolve processos interativos muito mais complexos. Para responder as questões, a licencianda e a professora mais uma vez fizeram perguntas para trazerem as vozes dos alunos, buscando perceber como eles estavam entendendo a atividade. A primeira pergunta que a licencianda faz se refere aos objetivos na atividade de experimentação realizada. Apesar de terem discutido isso anteriormente, os estudantes não conseguem responder claramente porque estavam montando o terrário. Nesse contexto, recuperar esse entendimento é importante para que possam interagir com a atividade e o texto que devem produzir. Eles respondem à questão com um novo sentido ("Para ver as plantas nascendo") e depois, ao serem questionados pela licencianda, conseguem trazer apenas uma palavra relacionada ao sentido que ela queria que construíssem (Ecossistema).

A partir da discussão, a professora constrói um raciocínio com os alunos sobre o ciclo da água no terrário. O diálogo envolve a passagem de gêneros primários mais simples que os alunos trazem (por exemplo, "Porque vaificar igual um pinga pinga") para gêneros mais complexos que aparecem na fala da professora ("Vai acontecer o ciclo da água, literalmente, porque o vapor de água que evaporar não vai para atmosfera, ele fica preso aqui dentro e vai, como a Geovana disse, vai condensar e vai cair de volta na terra, certo?"). Assim, a professora vai buscando trazer a linguagem científica para o diálogo. Depois, a construção do raciocínio segue para reflexão sobre a produção de gás carbônico e gás oxigênio no terrário. 
Nesse momento, é importante perceber como uma das alunas menciona o processo da fotossíntese, mostrando como esse conceito estava presente em seu sistema de conhecimento de mundo.

Após a discussão da segunda questão, a licencianda passou rapidamente para a terceira pergunta do roteiro. Não acompanhou a produção textual das respostas dos alunos. Assim, a atividade de escrita acabou tornando-se reduzida, pois não houve um trabalho específico e mais atento ao que os estudantes escreviam após a discussão. Isso pode estar relacionado à ideia de que os estudantes nessa idade já sabem ler e escrever, de forma que se foram capazes de oralmente produzir um raciocínio científico, poderão escrever sobre ele. No entanto, diante das dificuldades que os estudantes tiveram de escrever a resposta escrita, vemos que processos de ensino-aprendizagem de leitura e de escrita são ainda muito necessários.

“- Seguem logo para a leitura e discussão da questão três. A licencianda não espera eles escreverem a resposta da questão dois. Parece preocupada com o tempo da aula.

Licencianda: Gente, gente, quem lê a três, por favor?

(...)

Estudante F lê: Lembrando-se do ciclo da água, no qual a água sofre evaporação da superfície de rios, oceanos, lagos, pela transpiração de plantas e dos seres vivos e retornando na forma da chuva que irriga a terra e as plantas. Esse ciclo está representado no terrário? De que modo? Explique.

- Os alunos não estão participando. A professora oferece para quem responder a três usar o quadro. A licencianda oferece a aranha que encontraram no laboratório para ficar no terrário de quem responder. Eles parecem não saber como responder. A aluna Thaís tenta sozinha reler a questão em silêncio para depois ir ao quadro. Ela chama uma amiga do grupo para acompanhá-la. Elas conseguem explicar, mas de forma confusa. A professora precisa ajudar bastante.

Professora: Quem vai responder a três, vai no quadro. Quem sabe responder?

Estudante J: Deixa eu ver se eu sei

(...)

Professora: Vamos lá, meninas. O que que vai acontecer com a água no terrário?

Estudante C: A água vai evaporar e quando bater na tampa ela vai virar líquido de novo e vai descer.

Professora: Mas, ela vai evaporar e o que vai acontecer, a água não vai entrar na planta, não? (...) O que que a planta usa para fazer a fotossíntese?

Estudante C: A água, o ar... 
Professora: Então, a água entra na planta, certo? E aí, o que que a planta vai fazer com a água que entra nela? Vai... Como é que você elimina água do seu corpo? Trans...

Estudante E: Transpirando

Professora: E aí o que que vai acontecer com a água quando ela bater ali no papel?

Estudante G: Vai absorver

Professora: Ela vai con...

Estudante H: Condensar

Professora: Ela vai condensar. Foi galera? Todo mundo entendeu o ciclo da água, né?

- Depois da discussão, a professora e a licencianda ajudam os alunos a vedarem o terrário com insulfilme. $\mathrm{O}$ sinal bate, mas alguns alunos continuam no laboratório tentando terminar de responder as perguntas para entregar. A maior parte dos alunos sai, ficam poucos por grupo acompanhando o que está sendo escrito no roteiro". (Notas do diário de campo e transcrição de audiogravação).

Durante a observação, notamos que os estudantes tiveram muita dificuldade para responder a terceira pergunta do roteiro, talvez associada à leitura da pergunta. Parece que os alunos não conseguiram construir um sentido para a pergunta elaborada. A licencianda e a professora não fizeram a mediação da leitura da pergunta, o que deve ter influenciado na possibilidade inicial de interação dos estudantes com o texto, por isso nem começaram a tentar responder a pergunta, mesmo com o incentivo adicional oferecido (ida ao quadro ou colocar a aranha no terrário). Os estudantes passaram a participar se colocando no diálogo apenas depois que a professora formulou uma outra questão, mais simples ("O que que vai acontecer com a água no terrário?’). A partir daí, conseguiram interagir, mas, um número pequeno de alunos participou. Uma das questões que pode ter afetado a participação dos alunos foi o tempo para realização da atividade. Este parece ter influenciado negativamente na forma como a discussão foi desenvolvida ao final da experimentação. Como o tempo de aula estava terminando, a professora e a licencianda não conseguiram se dedicar com mais profundidade ao processo de escrita das respostas. Isso provavelmente limitou a articulação entre a experimentação e processos de ensino-aprendizagem de leitura e de escrita. Outra limitação importante foi estabelecida por uma questão estrutural. Sem possibilidade de fazer cópias do roteiro para todos os alunos, a professora precisou trabalhar com um roteiro por grupo. Dessa forma, nem todos os alunos tiveram a oportunidade de produção textual. Os alunos que não participaram da produção do texto ficaram 
dispersos no momento da escrita e a maior parte se retirou logo após a discussão oral, ficando apenas um ou dois por grupo para escrita das respostas.

A seguir, apresentamos outra atividade experimental observada. A partir desse novo exemplo, construímos uma síntese do que foi discutido até aqui em relação à articulação entre experimentação e atividades de leitura e de escrita. Essa aula aconteceu no laboratório de Ciências da escola e foi uma aula demonstrativa. Os alunos ficaram muito contentes em ir para o laboratório e interagiram bastante com a prática e a discussão. Assim, mais uma vez destacamos o elemento motivacional de aulas experimentais.

A proposta da experimentação realizada está no Caderno Pedagógico do $3^{\circ}$ bimestre e seu objetivo é discutir o conceito de pressão atmosférica. No Caderno aparecem os procedimentos, um esquema do que deve ser feito e duas perguntas escritas sobre o experimento (COORDENADORIA DE EDUCAÇÃO DO RIO DE JANEIRO, 2016 a, pg. 32). A professora começou a atividade discutindo o objetivo da experimentação e realizando o levantamento de hipóteses com os alunos sobre o que imaginavam que iria acontecer:

“- Professora explica o objetivo dos experimentos.

Professora: Posso começar? Nós faremos dois experimentos sobre a pressão atmosférica. A gente vai visualizar que a atmosfera, apesar de ser feita por gases, apesar dos gases quase não terem peso, serem muito leves, a pressão atmosférica faz uma força sobre a gente, sobre as coisas. E a gente vai ver nesse experimento a força que a pressão atmosférica exerce primeiro com esse experimento na página 32."

- Explica o que eles vão fazer. Discute o que eles acham que vai acontecer.

Professora: O que que a gente vai precisar? Eu tenho esse copinho aqui que eu vou encher de água.

(...)

Professora: E aí, o que que a gente vai fazer? Tem o copo com a água, esse papelzinho aqui é chamado de papel de filtro. Eu escolhi ele só porque ele já está cortadinho (...) Mas poderia ser feito com qualquer papel. (...). O que que a gente vai fazer? Já peguei ele cortadinho, já enchi o copo com água e aí vou colocar esse papel aqui em cima e vou dar uma pressionadinha aqui no papel. Depois eu vou virar isso aqui de cabeça pra baixo. O que vai acontecer com o papel?

Estudantes: Vai molhar.

Professora: Vai molhar. Será que vai cair o papel ou será que ele vai ficar preso?

Estudante A: Vai ficar preso.

Professora: Será que a água então vai cair aqui do copo ou vai ficar presa aqui dentro?" (Notas do diário de campo e transcrição de audiogravação) 
Nesse trecho percebemos que a professora discute o objetivo do experimento. Essa discussão é importante para que conhecimentos interacionais sejam mobilizados e os estudantes interajam com a experimentação e depois tragam as reflexões e vivências para a produção escrita. O objetivo da experimentação acaba se articulando com os objetivos da escrita. Os estudantes realizam um experimento para aprender algo sobre o qual escreverão posteriormente, mostrando para professora (com a qual estabelecem a interação como leitora dos seus textos) o que aprenderam.

O objetivo colocado mostra que esse experimento se associa a tradições curriculares acadêmicas, articuladas a saberes de ciências de referência, nesse caso a Física, mas se associa também a tradições pedagógicas e utilitárias relacionadas a metodologias ativas de aprendizagem e à aprendizagem de leitura e escrita.

Percebemos que a interação entre a professora, a experimentação e os estudantes se estabelece também a partir das hipóteses levantadas. A discussão das hipóteses ajuda a ativar os conhecimentos de mundo dos estudantes para dialogarem com a atividade e a escrita posterior, especialmente conhecimentos de mundo que fazem parte do conteúdo que vieram construindo nas aulas de Ciências (como os gases que formam a atmosfera, seu peso, sua força, etc.). É importante destacar ainda que na enunciação dos objetivos e no diálogo sobre as hipóteses, ativam-se também conhecimentos linguísticos dos estudantes, relativos ao campo lexical das ciências, como o termo pressão atmosférica. Em relação à experimentação em si, o levantamento de hipóteses, como discutimos anteriormente, favorece a realização de atividades experimentais mais ricas, isto é, com maior possibilidade de influenciarem positivamente nos processos de aprendizagem de ciências. Porém, é preciso problematizar a forma como a professora descreve o objetivo do experimento. Ela acaba explicando os conceitos que vão aparecer na experimentação, antes mesmo de realizar o experimento, desta forma, não permite que os alunos elaborem esses conceitos a partir da empiria. $\mathrm{O}$ experimento acaba funcionando mais para a revelação de algo do que como meio para exploração e formulação de conceitos (VILELA et al, 2007). Em relação às possibilidades de leitura e escrita, defendemos que a forma como a experimentação é realizada influencia na forma como escrevem sobre ela. 
Depois da discussão, a professora realiza o experimento para os alunos observarem. Eles se envolvem bastante, fazem perguntas, questionam a professora, pedem para ela repetir e expressam admiração pelo que observaram.

“- A professora realiza o experimento de forma demonstrativa e explica o resultado.

Professora: Então vamos ver. 1, 2, 3 e já.

(...)

- A Professora tira a mão e o papel continua preso, mesmo de cabeça pra baixo.

Estudante A: Viu? Não falei que ia ficar preso!

Professora: E por que fica preso?

Estudante B: Por causa do ar

Professora: Agora ficou tudo molhado, mas isso aqui, tá vendo? A folha de papel está segurando toda a água! Por que? Porque a pressão do ar exerce uma força sobre esse papel, e está exercendo agora, depois que eu tirei a minha mão, parei de fazer pressão sobre o papel com a água. Então ela continuou fazendo essa pressão. Então apesar da gente achar que aqui não tem nada, aqui tem ar, e esse ar faz uma pressão contrária. Ele faz pressão aqui, aqui, aqui e aqui embaixo também e aí impede que isso tudo caia. (Professora aponta para o copo mostrando a pressão exercida envolta dele).

(...)

Estudante D: E se deixar um tempão? Vai cair?

Professora: Não sei, a gente pode testar, mas na hora que eu virar de novo, normalmente cai.

Estudante D: Por que?

Professora: Porque aí a força da pressão atmosférica vai mudar de direção. Vou tentar de novo. Não sei se cai não, hein?

- Professora vira o copo de novo e não cai o papel.

Estudante C: Meu Deus!

Professora: Caiu água, mas o papel não desprendeu. Vou tentar de novo porque eu sou corajosa.

- Professora repete e o papel não cai.

Estudante B: Se mexer cai.

Professora: Sim, se eu mexer vou fazer uma força contrária à pressão atmosférica. $\mathrm{E}$ a força que eu vou fazer com a minha mão, se for maior que a força da pressão atmosférica, vai fazer com que solte. Entendeu? Vai fazer força pra baixo." (Notas do diário de campo e transcrição de audiogravação).

No diálogo estabelecido nesse momento da aula, vemos a articulação de gêneros, complexificando o discurso. O estudante expressa a explicação de forma simples ("Por causa do ar") e a professora torna a explicação mais elaborada ("Porque a pressão do ar exerce uma força sobre esse papel, e está exercendo 
agora, depois que eu tirei a minha mão, parei de fazer pressão sobre o papel com a água. Então ela continuou fazendo essa pressão. Então apesar da gente achar que aqui não tem nada, aqui tem ar, e esse ar faz uma pressão contrária"). Assim, vai trazendo elementos da linguagem científica e atuando na ampliação de conhecimentos de mundo e linguísticos dos estudantes, importantes para que depois possam escrever.

“- Depois deles observarem e ouvirem as explicações, começam a responder as questões da página 32:

Professora: Então vamos responder. Vamos lá. Primeira questão. Presta atenção para vocês responderem.

- A professora lê a questão 1: Escreva o que você observou quando virou o copo.

Professora: $\mathrm{O}$ que que a gente observou quando viramos o copo?

- Alguns alunos respondem. A professora concorda e fala outras formas de responder.

Estudante A: Que a água ficou no copo.

Estudante D: Que a água ficou presa.

Estudante B: Que tinha uma pressão na água.

Professora: Isso. Pode ser. A pressão na água, a água não vazou, a água não caiu. Então vamos lá. Escrevam aí o que aconteceu. Então o que a gente observou? O papel não cai ou a água não cai.

- A Professora lê a segunda pergunta e explica o significado.

Professora: Anotaram a número 1? Vocês observaram que nem a água, nem o papel caíram. Certo? Aí tem a dois. Professora lê: Explique o que você observou. Comenta: Ou seja, por que que isso não cai?

- A professora responde à pergunta e fala devagar para os alunos escreverem. Muitos alunos ficam pedindo para ela repetir. Ela repete. Os alunos escrevem exatamente como ela fala.

Estudante B: Por causa da pressão atmosférica.

Professora: A pressão atmosférica faz uma força contra o papel e a água. Então a pressão atmosférica faz força contra o papel e a água.

Estudante E: O que do papel e da água?

Professora: Contra, né? Contrária. A pressão atmosférica vai fazer uma força contra o papel e a água. Professora mostra no copo.

Estudante F: Professora? A dois eu não entendi.

Professora :Porque a pressão atmosférica faz força contra o papel e a água.

Estudante F: Professora? Faz força contra o que?

Professora: O papel e a água.

Estudante F: Professora, a pressão atmosférica?

Professora: Faz força contra o papel e a água". (Notas do diário de campo e transcrição de audiogravação). 
Inicialmente, destacamos que a professora faz a mediação da interação entre os estudantes e o texto das perguntas, quando realiza sua leitura. Ela lê a pergunta e imediatamente constrói o sentido para os alunos, na primeira ("O que que a gente observou quando viramos o copo?”) e na segunda questão (“Ou seja, por que que isso não cai?"). Eles aceitam e interagem com o sentido construído pela professora, respondendo às perguntas que ela faz oralmente, antes de tentarem escrever as respostas. No diálogo sobre as respostas, vemos a articulação de conhecimentos cotidianos e conhecimentos científicos, associados a gêneros discursivos primários e secundários. Em alguns casos, as respostas nas quais os estudantes descrevem o que observaram são mais simples, com termos cotidianos ("Que a água ficou no copo" e "Que a água ficou presa"). Mas em outra resposta, verificamos a contribuição de termos científicos para descrição do que viram, que se confunde com a explicação do fenômeno (“Que tinha uma pressão na água”). Na resposta à questão dois, mais abstrata, visto que exige a explicação de um fenômeno científico, aparecem elementos da linguagem científica mais claramente, forçando o surgimento de um gênero discursivo secundário para a construção de sentido ("Por causa da pressão atmosférica"). Trazemos aqui uma discussão importante em relação a esse momento da aula. Vemos que a professora controlou o sentido produzido e não abriu espaço para os estudantes trazerem suas reflexões. Isso aconteceu na explicação do que as perguntas solicitavam e depois nas respostas, especialmente da segunda pergunta. Nessa questão, ela formulou a resposta e ditou para que os estudantes escrevessem. Nesse sentido, não permitiu que apresentassem suas formas de explicar e restringiu a possibilidade que a autoria aparecesse na resposta escrita que os estudantes estavam elaborando. Mesmo quando o estudante tenta colocar o que estava pensando ("Por causa da pressão atmosférica"), a professora não reforça sua colocação e torna a explicação final mais monológica. Notamos que alguns alunos, sem interagirem com o que a professora estava colocando, sentiram dificuldade para dialogarem com a explicação, que sendo bastante abstrata, pareceu mais difícil de entender e especialmente de escrever. Estas parecem reflexões fundamentais para as discussões sobre letramento científico no ensino de ciências. Como produzir espaços para processos de ensinoaprendizagem nos quais os alunos possam interagir com o fenômeno e a linguagem para ler e escrever temas tão abstratos? Ou seja, como podemos refletir sobre a 
linguagem científica nas aulas de Ciências de forma a ajudá-los a se apropriarem da possibilidade de falar, pensar, escrever e ler temas científicos abstratos? A professora conduz a experimentação com levantamento de hipóteses, realização do experimento e busca de uma explicação científica. Ao final realiza as atividades de escrita. Assim, garante o confronto das hipóteses dos alunos com evidências empíricas, como parece ser o mais produtivo em relação às atividades de experimentação escolar. Porém, ela limita as possibilidades de reflexão e de abstração na descrição inicial dos objetivos, ao explicitar os conceitos científicos, e na explicação dos resultados, ao centralizar o debate. Percebemos que essa centralização restringiu a possibilidade de os estudantes interagirem com a linguagem escrita para produzirem textos próprios com modelos científicos que explicassem o que observaram.

Em síntese, percebemos em nossa investigação que a experimentação didática pode ter um papel importante tanto para o ensino-aprendizagem de conteúdos específicos do ensino de ciências, quanto para o ensino-aprendizagem de aspectos relacionados à leitura e à escrita. Nesse sentido, é fundamental que esse tipo de atividade seja incentivado e entendido como uma proposta de reinvenção curricular, capaz de trazer reflexões também sobre a linguagem escrita nos espaçostempo das aulas de Ciências. As atividades experimentais observadas aconteceram associadas à leitura de roteiros e perguntas sobre os experimentos e, especialmente, articuladas à produção textual de respostas escritas. As professoras colocam que os estudantes têm maior facilidade de escrever quando partem de interações que vivenciam nas experimentações e destacam o aspecto motivacional que estas atividades potencializam. Ao longo das atividades de experimentação, o dialogismo se estabelece mobilizando: i) conhecimentos interacionais, articulados aos objetivos da escrita; ii) conhecimentos de mundo, ao trazerem discussões sobre os fenômenos; e iii) conhecimentos linguísticos associados ao campo lexical utilizado para explicação do que observaram. Essa mobilização é possível na discussão dos objetivos do experimento, levantamento de hipóteses, descrição dos resultados observados e construção de uma explicação científica para os mesmos. Todas essas etapas mostram o potencial deste tipo de atividade para contribuir no desenvolvimento das possibilidades de leitura e de escrita dos estudantes. A utilização da experimentação para ampliar processos de ensino-aprendizagem da escrita é limitada por questões estruturais (tempo pedagógico e recursos para cópia 
de roteiros escritos e para compra de materiais), pela forma como o diálogo é estabelecido (com maior ou menor incentivo ao aparecimento das vozes dos alunos), pela demanda de escrita solicitada (tamanho e tipo de resposta demandada, possibilitando maior expressão de autoria, ou não) e pela mediação de leitura e escrita realizada pelas professoras (forma como organizam a aula constroem os diálogos orais e escritos). Além da experimentação e o uso dos Cadernos Pedagógicos, as atividades avaliativas marcaram a interação com a linguagem escrita nas aulas de Ciências. Vamos analisá-las na próxima seção do texto.

\subsection{3. \\ Avaliação e possibilidades de leitura e escrita}

$\mathrm{Na}$ presente seção do texto, destacamos atividades que denominamos avaliações formais, isto é, provas escolares que foram observadas nas aulas de Ciências e envolveram atividades de leitura e/ou de escrita. Ao longo de nossas observações, percebemos que as avaliações formais aconteceram em muitas aulas e acabaram representando atividades importantes nas quais os alunos leem e escrevem. Do total de 59 tempos de aula de observação, em 19 tempos ocorreram provas (aproximadamente 32\% das aulas), incluindo as provas bimestrais elaboradas pela Secretaria de Educação do município do Rio de Janeiro (que as professoras e estudantes chamam de "prova da prefeitura"), provas bimestrais elaboradas pelas próprias professoras (que as professoras e estudantes nomeiam "prova da professora") e provas de recuperação, também elaboradas pelas professoras. De acordo com as professoras participantes, as provas não eram o único mecanismo avaliativo, pois consideravam vários outros instrumentos para comporem os conceitos bimestrais dos alunos, como participação nas atividades, realização das tarefas de casa, trabalhos escritos realizados em aula ou em casa, entre outros. Mas as provas pareceram ocupar um lugar importante no processo pedagógico, visto que fizeram parte de muitas aulas. Além disso, todo o ritual envolvido na realização das provas, marcam a relevância que receberam nas aulas de Ciências.

A avaliação é um tema de intenso debate teórico no campo da pesquisa em educação e envolve reflexões no âmbito das práticas escolares e das legislações educativas nacionais, como mostra o levantamento realizado por Dantas et al 
(2017). Não pretendemos aprofundar a discussão da avaliação na educação, visto que não é objetivo do estudo realizado. Porém, achamos importante trazer alguns aspectos relativos a este tema que contribuem para as reflexões sobre leitura e escrita nas aulas de Ciências.

Em relação às esferas de elaboração, as avaliações da educação podem ser externas ou internas. As avaliações externas dizem respeito àquelas desenvolvidas por instituições distantes do contexto escolar no qual são realizadas e costumam ser usadas como indicadores governamentais. Em nossa investigação, as avaliações externas observadas nas aulas de Ciências foram as "provas da prefeitura". As avaliações internas são compreendidas como aquelas elaboradas pelos responsáveis pela proposta educativa nas próprias escolas, na pesquisa as "provas da professora". Entendemos que estas avaliações permitiram a construção de relações com a linguagem escrita de maneira bem diferente. As "provas de prefeitura" e as "provas da professora" possuem características distintas e, dessa forma, o envolvimento com processos de ensino-aprendizagem de leitura e/ou escrita que os estudantes puderam vivenciar através delas também foi diferente.

Como discutido anteriormente, as "provas da prefeitura" de Ciências são aplicadas bimestralmente em todas as escolas da rede municipal de ensino do Rio de Janeiro. São associadas aos Cadernos Pedagógicos, que materializam orientações e descritores curriculares para a totalidade das unidades escolares. Os resultados destas avaliações integram índices para as escolas e bonificação salarial para os seus professores. De acordo com Luz (2016), essa forma de organização tem influenciado o cotidiano das escolas e tornado o trabalho docente cada vez menos autônomo. Schneider (2012) enfatiza que essa lógica, baseada em uma política de resultados, tem conduzido à fragilização de escolas já pauperizadas com baixos índices de aproveitamento, reforçando as desigualdades. Além disso, o autor destaca que há um risco das escolas se ajustarem para darem respostas a esses mecanismos de avaliações externas, reduzindo seus papéis nos processos de ensinoaprendizagem, excluindo conteúdos, métodos e objetivos que não sejam quantificáveis. Como coloca Esteban (2009), “A naturalização dos vínculos entre avaliação da aprendizagem (como exame), competitividade e qualidade, orienta as práticas escolares cotidianas para a realização de percursos já conhecidos, já que a reprodução parece favorecer bons desempenhos" (ESTEBAN, 2009, pg. 131). Dantas et al (2017) discutem especificamente a avaliação no ensino das Ciências 
Naturais e colocam que, de acordo com a revisão da literatura que fizeram, as avaliações externas padronizadas avaliam apenas o conteúdo que os alunos conseguem memorizar, e não outros aspectos importantes como o percurso do aluno, sua capacidade de trabalhar de forma coletiva e individual, a criatividade, autonomia, etc. Ainda problematizando a questão das avaliações externas, Dantas et al (2017) enfatizam as colocações que aparecem nas Diretrizes Curriculares Nacionais Gerais da Educação Básica (2010 apud DANTAS et al, 2017) que questionam o fato de estas avaliações desconsiderarem a singularidade de cada escola e de cada estudante e assim, negarem o contexto local em que cada escola está inserida. Esteban (2009) contribui com esse debate e discute que as avaliações externas têm favorecido nas escolas uma "pedagogia do exame", que cotidianamente busca reproduzir universais abstratos e atingir objetivos fixos que projetam aprendizagens padronizadas, em uma tentativa de homogeneizar as subjetividades, silenciando as diferenças, nomeando e hierarquizando os sujeitos. Refletindo sobre o nosso objeto de estudo, defendemos que essa padronização que é espelhada nas "provas da prefeitura" tem duas consequências principais para os processos de ensino-aprendizagem de leitura e escrita que ocorrem nos espaços das aulas de Ciências. Primeiro, pressionam o currículo e o tempo pedagógico, gerando a reprodução de conteúdos padrões, como discutimos nas reflexões sobre o uso dos Cadernos Pedagógicos, e diminuindo o tempo possível para o trabalho mais profundo de leitura e escrita, como vimos na discussão sobre a experimentação, por exemplo. Além disso, a pressão sobre o tempo pedagógico reduz as possibilidades de investimento em processos individuais dos estudantes para a aquisição da linguagem escrita. Entendemos ainda que as avaliações externas, ao se afastarem dos contextos locais, diminuem a possibilidade de interação dos estudantes com os textos. Ao ignorarem os processos sócio-cognitivos que os estudantes vivenciaram nas relações de ensino-aprendizagem das aulas, desconsideram a diversidade de possibilidades de interação com aquele conteúdo e aqueles textos. Não há como saber para cada escola da rede de que forma os conteúdos foram trabalhados, que dificuldades apareceram, que interações foram desenvolvidas, que reflexões foram construídas e que processos de ensino-aprendizagem foram experimentados, inclusive de leitura e escrita. Todas essas questões são desconsideradas e cria-se uma prova única para diferentes sujeitos, em diversas escolas, em variados locais. Se para ler dependo das interações vivenciadas e essas são ignoradas, parece-nos 
que o potencial da avaliação se tornar um momento de ensino-aprendizagem de leitura e escrita fica reduzido.

Para refletir melhor sobre o que foi colocado, apresentamos a seguir três questões de avaliações escolares. As duas primeiras eram de uma "prova da professora" e a terceira era de uma "prova da prefeitura". As três questões trazem reflexões sobre atividades de experimentação e foram aplicadas ao final do terceiro bimestre de 2016 para uma das turmas observadas (FIGURA 17 A e B: provas "da professora" e "da prefeitura", respectivamente).

A)

Aluno

Turma:

Data.

PROVA DE CIÊNCIAS $6^{\circ}$ AnO $-3^{\circ}$ BIMESTRE

1) $(0,8)$ Num experimento feito no laboratônio, mergulhamos um copo com algodầ em seu fundo, numa vasilha cheia de agua, como mostrado na imagem abaixo.

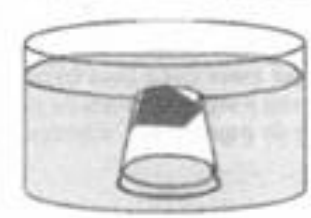

Quando levantamos o copo vimos que o algodâo saia seco. Explique por que o algodào sai seco nessa situaçăo.

2) $(0,8)$ Num outro experimento, acendemos una vela e colocamos um copo sobre a vela, como mostrado na imagem abaixo:

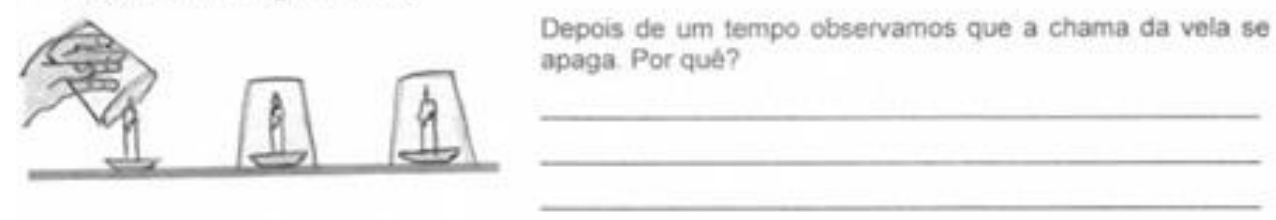

B)

QUESTÃo 1
Os alunos da turma 1603 realizaram um experimento com um vegetal. Veja, nas imagens
abaixo, o resultado do experimento.
O plástico ficou "suado", pois ocorreu a condensação de um dos componentes do ar
eliminado pela transpiração do vegetal.
Esse componente é o
(A) gás oxigênio.
(B) vapor d'água.
(C) gás nitrogênio.
(D) gás carbônico.

FIGURA 17: Questões sobre experimentação em provas de Ciências de uma turma de sexto ano do ensino fundamental de 2016. A) Elaborada pela professora da turma. B) elaborada pela Coordenadoria de Educação do município do Rio de Janeiro. 
Utilizamos essas questões para comparação das provas por terem um tema parecido, experimentos escolares, o que facilita a análise. Percebemos que a forma como a pergunta é construída difere entre as duas provas. Na "prova da prefeitura" cria-se uma situação imaginativa, visto que não é possível garantir que em todas as escolas essa experimentação tenha sido realizada. Nas questões da "prova da professora", as perguntas são construídas na primeira pessoa do plural, pois os experimentos sobre os quais os questionamentos são feitos foram efetivamente realizados com a turma. Assim, quando leem a questão, os estudantes podem lembrar e pensar sobre situações que vivenciaram, facilitando a criação de sentidos. Claro que muitas vezes os estudantes precisam ler e/ou escrever sobre algo que não realizaram concretamente, ampliando suas possibilidades de interação com textos. Mas, considerando o desenvolvimento de seus processos de aprendizagem de leitura e de produção textual, a possibilidade de produção de sentidos será facilitada se partir de interações sociais que vivenciaram, para então poderem ler e escrever sobre esses conhecimentos abstratos. Especialmente para os alunos com maiores dificuldades na relação com a linguagem escrita.

A seguir, apresentamos outras questões de avaliações para fins de comparação entre a "prova da prefeitura" e a "prova da professora". Escolhemos duas questões que abordam o mesmo conteúdo, isto é, raios ultravioletas e camada de ozônio. A primeira estava na "prova da professora" e a segunda na "prova da prefeitura" (FIGURA 18 A e B: provas "da professora" e "da prefeitura", respectivamente).

A) 9) (0,8) A camada de ozônio è uma camada de gás que fica na estratosfera. Qual a importância dessa camada para a vida dos seres vivos?

B)

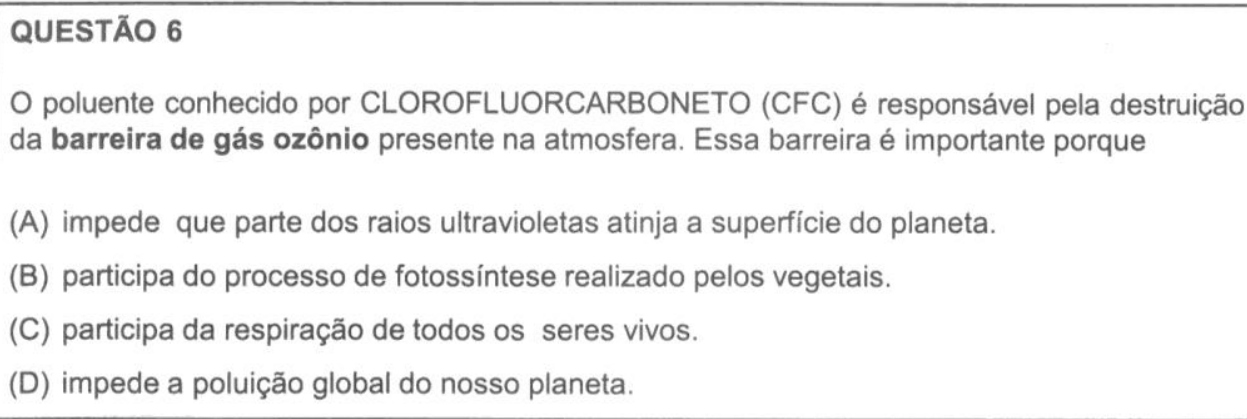

FIGURA 18: Questões sobre camada de ozônio de provas de Ciências de uma turma de sexto ano do ensino fundamental de 2016. A) Elaborada pela professora da turma. B) elaborada pela Coordenadoria de Educação do município do Rio de Janeiro. 
Percebemos que a questão elaborada pela professora traz elementos dos diálogos estabelecidos com os estudantes nas aulas de Ciências. A pergunta envolveu um tema abordado na sala de aula e a demanda se relacionou a uma questão específica sobre a qual discutiram oralmente, gesticularam, leram e escreveram anteriormente. Percebemos que até a forma como a pergunta é enunciada, sua composição, se relaciona ao que a professora julgou mais importante de trabalhar com os alunos. Assim, o contexto local, as vivências que tiveram e as interações que estabeleceram nas aulas são consideradas na prova. Na aula na qual discutiram a camada de ozônio, a professora e os estudantes não ficaram concentrados na substância clorofluorcarboneto (CFC), que na "prova da prefeitura" se torna um termo importante, a ponto de estar escrito todo em letra maiúscula e com uma fonte maior que o resto da pergunta. Na aula envolvendo o tema da camada de ozônio, pensaram sobre como os raios ultravioletas afetam os seres vivos, e principalmente os humanos, discutiram câncer de pele, uso de protetor solar, horário de ir à praia, entre outras questões que se relacionavam ao cotidiano dos alunos. A partir dessas questões é que construíram sentidos e conhecimentos sobre os raios ultravioletas e a camada de ozônio, como vemos no diálogo abaixo:

\footnotetext{
"Professora: Na estratosfera tem uma coisa muito, muito importante para gente. Sem essa camada da nossa atmosfera, os seres vivos não existiriam aqui.
}

Estudante A Não?

Professora: Não. Sem essa camada não. Vou explicar porque. Na estratosfera a gente encontra uns gasisinhos acumulados aqui. Que ficam aqui assim nela, e a gente vai chamar essa camada desses gases de camada de ozônio.

(...)

Professora: Só que por que essa camada é tão importante para vida dos seres vivos?

Estudante B: Porque ela ajuda a gente.

Professora: A gente já sabe que quem manda luz e energia para gente...

Estudante C: É o sol

Professora: É o sol. Manda luz, energia (desenha o sol no quadro)... A gente sabe que nessa camada aqui tem o efeito estufa, a camada de gás carbônico, que deixa uns saírem, e outros ficam. Mas a camada de ozônio ela é um filtro. Ela é um filtro da luz do sol que é ruim para gente.

Estudante D: Filtro solar.

Professora: É um filtro solar natural. Vocês sabem qual o raio do sol faz mal para gente?

Estudante E: É... Raio Solar? 
Professora: Ultravioleta. Quando o raio ultravioleta (escreve no quadro raio ultravioleta e vai falando: ó Raio ul-tra-vi-o-le-ta).

Estudante A: Não deixa a luz solar entrar.

Professora: Isso. Ele faz uma barreira. E o raio bate e volta. Alguns ainda passam...

(...)

Professora: Primeiro quero que vocês pensem por que que o raio ultravioleta do sol é ruim para gente.

Estudante E: Por causa que faz mal pra pele.

Professora: Dá câncer de pele.

Estudante E: Queima a gente. Porque é muito forte.

Professora: Queimar, queimar não. Não faz uma queimadura. Mas ele pode mexer lá no nosso DNA das nossas células e causar câncer de pele. Todo mundo sabe que isso não é uma coisa boa, né?

(...)

Professora: E se as plantas receberem muita quantidade de raio ultravioleta, elas não conseguem fazer fotossíntese. E aí sem fotossíntese não temos oxigênio, não temos comida, e temos muito aquecimento global, né? Isso... Aí essa camada de ozônio então, ela faz um filtro bloqueando esses raios que são ruins para gente. Então a camada de ozônio é boa ou ruim?

Estudantes: Boa!

(...)

Professora: A camada de ozônio é boa porque ela filtra os raios ultravioletas que são ruins pra gente. Que causa câncer de pele, que não deixa que as plantas façam a fotossíntese.... Agora, porque eu falei pra Carolina que nem sempre essa camada filtra tudo, depende? A gente tá naquele dia de verão, né, na praia. Verão nas férias, a gente quer chegar na praia cedo, né? Que horas vocês chegam na praia, no verão, nas férias?

Estudante F: Meio-dia, uma hora.

(....)

Professora: Forte. Direto na nossa cabeça. Aí, vocês são inteligentes, vocês passaram protetor solar. Porque vocês são inteligentes, tem que passar o protetor solar. Passou protetor solar. Só que vocês passaram só uma vez. Ficaram o dia inteiro na praia, saíram de lá sete da noite, porque é horário de verão. E aí?

Estudante F: Ishhh...

Professora: Ishhh. Isso aí. Fez bem para você? Mas, não tem a camada de ozônio que tá lá protegendo a gente? Mas nesse horário, de dez às quatro da tarde, o sol é tão intenso, especialmente no verão, que passam mais raios ultravioletas. Mesmo quando o tempo tá nublado, tá meio frio, a gente sempre tem que sair de casa com protetor solar. (...)" (Notas do diário de campo e transcrição de audiogravação).

Esse diálogo estabelecido em sala de aula, no momento em que interagiam com um texto do Caderno Pedagógico que aborda as camadas da atmosfera, mostra como a maneira através da qual discutiram sobre a camada de ozônio se assemelha à questão da "prova da professora", mas não à "prova da prefeitura". A interação 
vivenciada na aula ativa e amplia os sistemas de conhecimentos para leitura e escrita através do dialogismo estabelecido, de forma que depois os estudantes podem acessar esses conhecimentos para dar sentido ao que leem e ao que escrevem na questão da "prova da professora". Na "prova da prefeitura", a pergunta não parte de uma interação anterior e o processo de leitura pode se tornar mais complicado.

Nas questões a seguir, mais uma vez notamos que a maneira como a pergunta foi construída pela professora se aproxima mais do diálogo estabelecido em aula que a da "prova da prefeitura" As duas questões abordam o conteúdo de

A)

$\mathrm{u}$

7) $(0,8)$ Explique por que lavar bem as mãos antes de levá-las a boca é importante para năo pegarmos gripe.

p

e

B)

\section{QUESTÃO 7}

O uso de máscaras é indicado para pessoas que contrairam doenças transmitidas pelo ar contaminado.

Marque a opção que contém o nome de uma doença transmitida pelo ar contaminado:

(A) Verminose.

(B) Dengue.

(C) Diarreia.

(D) Gripe.

FIGURA 19: Questões sobre doenças retiradas de provas de Ciências de uma turma de sexto ano do ensino fundamental de 2016. A) Elaborada pela professora da turma. B) elaborada pela Coordenadoria de Educação do município do Rio de Janeiro.

O diálogo estabelecido em aula mostra um dos momentos no qual o tema foi trabalhado em aula. Percebemos que a interação estabelecida em aula mais uma vez se aproxima da pergunta elaborada pela professora, aumentando a possibilidade que os estudantes deem sentido ao que está sendo perguntado e produzam um texto sobre isso.

“- Professora faz um teatro de transmissão de vírus de um para o outro. Os alunos prestam atenção e participam.

Professora: O vírus do meu espirro passou para minha?

Estudantes: Mão!

Professora: E aí passei para... (a professora coloca a mão na mesa).

Estudantes.: Mesa. 
Professora: Aí, ele pegou botou a mão na mesa, depois foi roer a unha, aí foi no refeitório pegou uma maçã. Do meu corpo passou pra mesa, da mesa pra mão dele e aí ele não lavou a mão antes de comer, não lavou a mão antes de roer a unha, que não deve roer nem se a mão tiver limpa, antes de comer a fruta... Aí os vírus que estavam na mão dele foram pra onde?

Estudante A: Pra maçã!

Professora: E aí pro corpo dele. E aí? Ele poderia ter evitado isso?

Estudantes: Sim!!!

Professora: Lavando a mão, né?" (Notas do diário de campo e transcrição de audiogravação)

Os últimos exemplos que apresentaremos para comparação são de questões que envolviam o tema do aquecimento global. Novamente, as perguntas elaboradas pela professora se referiam a diálogos vivenciados anteriormente em salas de aula e incluíam os alunos na interação com os textos da prova, como vemos na pergunta com o termo você no item $\mathrm{C}$ da questão. $\mathrm{Na}$ "prova da prefeitura" há um texto (igual ao do Caderno Pedagógico), mas a pergunta inclui apenas o nome dos gases. Abaixo as questões (FIGURA 20 A e B: provas "da professora" e "da prefeitura", respectivamente) e em seguida um momento observado em uma aula que tratava do tema. 
A) 4) O aquecimento giobal é um grande problema para o nosso planeta.

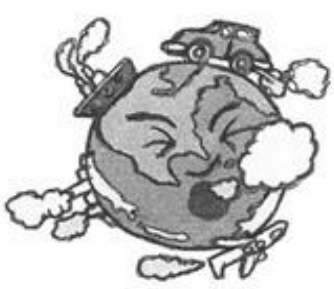

a) $(0,8)$ Observando 0 desenho abaixo, como o ser humano contribui para o aquecimento global.

b) $(0,4)$ Qual o gás que provoca o aquecimento global?

c) $(0,8)$ Cite duas medidas que você pode fazer para evitar o aquecimento global.

B)

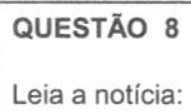

Em dezembro de 2015, a COP-21 (Conferência do Clima da ONU) terminou em Paris com um acordo histórico que, pela primeira vez, envolveu quase todos os paises do mundo em um esforço para evitar o aquecimento global.

Para que o acordo firmado em Paris tenha resultado, é necessário reduzir a emissão dos gases atmosféricos que impedem a saída da radiação solar de nosso planeta, como o gás
(A) metano e o gás carbônico.
(B) oxigênio e o gás carbônico.
(C) oxigênio e o gás hidrogênio.
(D) metano e o gás hidrogênio.

FIGURA 20: Questões sobre o aquecimento global retiradas de provas de Ciências de uma turma de sexto ano do ensino fundamental de 2016. A) Elaborada pela professora da turma. B) elaborada pela Coordenadoria de Educação do município do Rio de Janeiro.

Analisando as questões, há uma pergunta semelhante nas duas provas, o item b da "prova da professora" e a pergunta da "prova da prefeitura". Esse tema foi abordado nas aulas, o nome dos gases, mas percebemos que não foi o conteúdo mais valorizado pela professora (inclusive na sua prova, essa questão tem uma pontuação menor). O trecho abaixo foi transcrito de uma aula na qual a turma estava corrigindo com a professora um exercício escrito que tinham feito no caderno, como um dever de casa. Os estudantes deveriam escrever respostas a perguntas que a própria professora tinha passado no quadro na aula anterior. Notamos que o diálogo estabelecido com os alunos foi mais longo em relação a causas e consequências do aquecimento global. 
"Professora: A questão quatro: o que é o efeito estufa e qual a importância desse fenômeno?

Estudante A: É um fenômeno natural que mantém o planeta quente.

Professora: Isso.

(...)

- Professora: Então o efeito estufa é um processo que permite que parte dos raios solares permaneçam no planeta.

Estudante B: Pode deixar fenômeno natural?

Professora: Pode deixar fenômeno natural e completar com isso.

Professora: E a importância desse fenômeno é o que? É manter o planeta aquecido, quente.

(...)

Professora: Aí a questão cinco. Quais os gases que provocam o efeito estufa?

Estudante A: Metano e carbônico

Professora: Isso. Gás Carbônico e gás metano.

(...)

Professora: A sexta. A vida em nosso planeta seria possível sem o efeito estufa?

- Discutem a resposta. Alunos participam. Aluno questiona a professora. Professora escreve no quadro e espera eles copiarem.

Estudante B: Não.

Professora: Por que não?

Estudante B: Porque de dia ia ficar muito calor e a noite muito frio.

Professora: Isso

(...)

Professora: De dia ia ser quentinho por causa do sol mandando energia. Agora de noite, sem o sol, ia ser extremamente frio.

Estudante C: Não, não ia.

Professora: Ia ser. A diferença seria bem grande.

- Criam hipóteses do que aconteceria.

Estudante C: Mas teria a vida.

Professora: Quem disse que teria vida? Sem o calor do sol? Será que a gente estaria aqui? Talvez bactérias, seres vivos mais simples...

Professora escreve sua resposta no quadro: Não, pois a variação da temperatura seria muito grande. De dia seria muito quente e a noite extremamente frio.

(...)

Professora: A número sete. O que é o aquecimento global?

Estudante D: É aumento da temperatura 
Professora fala e escreve no quadro: É o aumento da temperatura do planeta.

- Professora espera eles escreverem.

Professora: Aí a questão oito. O que está causando o aquecimento global?

Estudante A: A fumaça das fábricas e dos carros.

Professora: A fumaça das fábricas, a fumaça dos carros, tá? Das queimadas, especialmente florestas...

(...)

Professora: Então ó, quando a gente fala a fumaça das fábricas, a fumaça dos carros a gente tá pensando na queima, no processo de combustão então dos combustíveis, que a gente chama de fósseis.

Estudante D: O que é isso?

Professora: Que são aqueles que foram formados há muito tempo, a gasolina, o diesel.

Professora: Então, ao invés de fumaça vou colocar assim: (fala e escreve no quadro) A queima dos combustíveis fósseis. Professora fala: Ó, esses combustíveis que lançam um monte de fumaça, um monte de gás carbônico na atmosfera, são chamados de combustíveis fósseis. Foram formados há muitos e muitos anos atrás. Além disso, vou botar a queimada das florestas (fala e escreve).

(...)

P.: E a nove e última. O aquecimento global é bom ou ruim para o planeta?

Estudantes: Ruim.

Professora: Muito ruim.

Professora: Que motivos? Pedi para citar dois motivos que justifiquem porque ele é ruim. (Pergunta: Dê dois motivos que justifiquem sua resposta).

(...)

Professora: Pode causar a extinção de seres vivos, como eu falei pra vocês dos seres que vivem lá nos locais onde tem gelo, no Ártico, na Antártica, nos pólos do planeta. Porque vai derreter as geleiras, aí esses animais podem entrar em extinção... E se derrete as geleiras? Que que vai acontecer?

Estudante B: Não vai ter mais água doce no planeta.

(...)

Estudante C: Vai misturar com a água salgada.

Professora: Isso. Mas e aí? O nível dos oceanos? O que vai acontecer?

Estudante A: Vai aumentar.

(...)

Professora: Vai provocar a extinção de espécies de seres vivos e aumentar os níveis dos mares. (...)" (Notas de diário de campo e transcrição de áudiogravação)

Os três exemplos de questões apresentados mostram como a avaliação externa, ao uniformizar e homogeneizar os contextos, se afasta das interações que 
os estudantes vivenciaram nas salas de aula. Acreditamos que ao desconsiderarem a singularidade dos processos pedagógicos desenvolvidos com cada turma, reduzem a possibilidade que os estudantes construam sentidos para o que leem, visto que a leitura depende que os leitores levem, para interação com o texto e o autor, seus conhecimentos, sua história de vida, suas reflexões, seu mundo. Sem poder interagir com o que os estudantes efetivamente experimentaram nos seus processos de ensino-aprendizagem, as avaliações acabam focando em questões memorísticas e reduzem o trabalho pedagógico, como colocam Dantas et al (2017). Uma das professoras trouxe uma fala em relação às "provas da prefeitura" em sua entrevista. Ela comparou a forma como acredita que deva se construir o trabalho pedagógico e a maneira como as perguntas aparecem no Caderno Pedagógico e na "prova da prefeitura". Coloca que são perguntas fáceis, pois não exigem reflexões ou associações entre textos e situações distintas, demandam apenas responder o que está expresso claramente no texto ou memorizado. "Assim, da forma como formular as perguntas. Não dá para eu.... A bola é azul. Eu vou perguntar de que cor é a bola? (...) Tem que ser perguntas que eles possam pensar mais. (...) E a prova da prefeitura é a mesma coisa. São perguntas fáceis."

Podemos perceber isso nas questões apresentadas anteriormente, por exemplo "Marquem o nome de uma doença transmitida pelo ar contaminado" ou “(...) Esse componente é o.... “ ou ainda “(...) como o gás...”, que exigiam apenas que os estudantes soubessem o nome da doença, do gás eliminado na transpiração vegetal e daqueles que amplificam o aquecimento global.

Alguns autores discutem que as avaliações externas têm um papel importante para garantir o diagnóstico e monitoramento da qualidade da educação (ZAMPIRI e SOUZA, 2014 apud DANTAS et al, 2017). Consideramos que essa realmente pode ser uma função relevante das avaliações externas, mas é preciso refletir e questionar a forma como tem controlado o trabalho realizado nas escolas e as consequências desse processo. Em relação ao ensino-aprendizagem da leitura e da escrita, as avaliações externas, ao se afastarem dos contextos dos estudantes, não funcionam como uma atividade pedagógica formativa na relação com a linguagem escrita e nem investigativa, apenas classificam os alunos.

O processo avaliativo pode ser concebido nas escolas de duas maneiras, como prática de classificação ou como prática investigativa (ESTEBAN, 2009). A avaliação que tradicionalmente é encontrada nas escolas funciona como uma prática 
de classificação, que serve para hierarquizar e selecionar os alunos, marcando o fracasso escolar ou o não saber (ESTEBAN, 2009). É uma prática que encerra o processo pedagógico compreendido como linear, que começa no planejamento e termina na avaliação formal. A avaliação investigativa, por outro lado, serve como meio para reflexão docente sobre sua ação e sobre a aprendizagem dos estudantes, é parte do processo de construção de conhecimentos e marca o que a criança ainda não sabe, que será retomado novamente, para que possa saber (ESTEBAN, 2009). O processo pedagógico funciona como um ciclo ou uma espiral e não uma sequência linear. Segundo a autora, a lógica política mercadológica da educação, que relaciona os processos pedagógicos a avaliações externas e bonificação dos professores, reforça a concepção classificatória do processo avaliativo. Além disso, ao buscar um projeto educativo que tenta homogeneizar todas as escolas e estudantes, nega o reconhecimento dos contextos culturais diferentes e trabalha com uma perspectiva de simplificação que não tem servido para favorecer uma dinâmica de ensino-aprendizagem que atenda às classes populares (ESTEBAN, 2009). Parece-nos que as "provas da prefeitura" funcionam assim, negam as diferenças e buscam uma homogeneização que reduz o processo pedagógico, inclusive os processos de ensino-aprendizagem da linguagem escrita.

A elaboração pelas professoras de suas próprias provas, que se diferenciam das provas da prefeitura ao trazerem para o diálogo aquilo que vivenciaram nas aulas, é uma forma de resistência ao processo de redução de suas práticas pedagógicas e de controle sobre o seu trabalho. É mais uma maneira que encontram de exercerem seu "poder localizante" (KINCHELOE, 2001). Em uma das falas, a professora reflete sobre a avaliação como prática investigativa, que servirá para identificar o que os alunos ainda precisam aprender em relação à leitura e à escrita "Eu não gosto de fazer prova de múltipla escolha justamente para identificar os problemas deles de interpretação. (...) E na escrita".

Por outro lado, o grande número de aulas com provas formais, a valorização das notas e a centralidade das avaliações externas reforça a ideia da avaliação como prática de classificação nas escolas observadas. Essa concepção aparece nas falas dos alunos:

"Estudante A: (...) porque na hora que a professora te dá a prova e manda fazer, na tua cabeça já deu aquele branco, não sei de nada.

Estudante B: Não sei de nada. Aí a gente fica lá mesmo, tentando ler a palavra... 
Estudante C: Aí você entende o texto e não entende a pergunta.

Estudante D: Tipo você se mata de estudar e quando vai ver sua nota, um horror! Quando vai ver...

Estudante A: (...) quando tá chegando no fim do ano e as notas vão acabando, as pessoas ficam mais nervosas.

Estudante B: Medo de acabar e repetir.

Estudante A: Mesmo que saiba, fica impaciente, nervoso e acaba errando". (Grupo de alunos de uma das escolas estudadas).

As falas dos alunos mostram a dificuldade que sentem na prova e a visão da avaliação como o lugar do fracasso escolar. Aqui a avaliação é entendida como o fim do processo. É importante notar que nos comentários, associam as dificuldades nas provas a dificuldades de leitura "Aí a gente fica lá mesmo, tentando ler a palavra..." e "Aí você entende o texto e não entende a pergunta". Uma das professoras em sua fala também trouxe essa relação entre dificuldades para responder questões da prova e dificuldades para ler, ou para construir um sentido ao que leem nas perguntas das avaliações “(...)os alunos não conseguem responder questões das minhas provas porque eles não entendem o que está sendo perguntado". E coloca ainda que as dificuldades nas provas de Ciências não estão em termos científicos, mas em palavras comuns “(...) A dificuldade das palavras difíceis é cite, explique...”. Isso reforça como as avaliações se associam às questões de leitura e de escrita.

Embora sempre envolvam a linguagem escrita, pois se realizam através da mesma, acreditamos que algumas práticas avaliativas favorecem mais processos de ensino-aprendizagem associados à leitura e/ou à escrita que outras. Dentre as avaliações formais que observamos, defendemos que as provas "das professoras" serviram mais a este processo do que as provas "da prefeitura". Primeiramente, porque, como discutimos, partem de situações que foram vivenciadas na sala de aula, ampliando a possibilidade que os alunos possam interagir com os textos que tratam das mesmas. Depois, parece-nos que a "prova da professora" funciona como um processo de ensino-aprendizagem da linguagem escrita porque as professoras fazem outras atividades utilizando esse material, que estão além do momento que os estudantes efetivamente fazem as provas. Elas leem com os alunos a prova e explicam as questões antes da avaliação em si, tiram dúvidas individuais de leitura e escrita durante a prova e depois a corrigem coletivamente com a turma, dialogando com os estudantes sobre as respostas. Dessa forma, as avaliações se 
tornam uma atividade pedagógica formativa, não apenas classificatória. Acreditamos que o mesmo não acontece com as avaliações externas, pois sem estarem envolvidas com a prova, as professoras não a utilizam para outros processos de interação com os estudantes. Além disso, há regras de aplicação das avaliações externas que não permitem o trabalho anterior à execução das provas, como, por exemplo, a leitura das questões, e nem a discussão de dúvidas individualmente. Para aprofundar esta reflexão, trazemos a seguir um trecho da aula observada na qual a professora aplicou a prova que continha as questões apresentadas como exemplos (FIGURAS 17, 18, 19 e 20). Destacamos a maneira pela qual, inicialmente, a professora discute as questões da prova, antes que os alunos comecem a ler e a escrever individualmente. Assim, a professora faz a mediação da interação dos estudantes com a prova, e, dessa forma, processos de ensino-aprendizagem de leitura e de escrita acontecem.

"Professora: É.... eu vou passar a prova e vou ler junto com vocês as questões, tá? Então não comecem a prova, para gente poder ler e explicar juntos, tá bom?

(...)

Professora: Eu vou explicar, vou ler, e ninguém vai responder nada é só para prestar atenção.

- Às 15:26 h. a professora começa a ler a prova e explicar as questões. Ela lê com entonação e explica o que está sendo pedido.

Professora: A primeira questão. Lê: Em um experimento feito no laboratório, mergulhamos um copo com algodão em seu fundo numa vasilha cheia de água, como mostrado na figura abaixo. Comenta: A gente fez isso no laboratório, pegamos um copo, colocamos algodão e mergulhamos, depois tiramos.

- Um aluno faz um comentário lembrando do que eles fizeram e a professora reclama.

Professora: Eu falei que ninguém fala nada. Nada! Lê: Quando levantamos o copo vimos que o algodão saía seco. Comenta: Você vai explicar por que o algodão sai seco nessa situação. Então por que que, o algodão que está dentro do copo, a gente mergulhou o copo, quando a gente levanta e mexe no algodão, ele tá seco? Vai explicar por que que isso aconteceu.

- Alguns alunos começam a querer escrever a resposta. A professora manda esperar ela terminar de ler toda prova para depois fazerem. Os alunos reclamam. Ela segue a leitura.

(...)

Professora: Na segunda questão. Lê: Em outro experimento acendemos uma vela, colocamos um copo sobre a vela como mostrado na imagem abaixo, depois de um tempo observamos que a chama se apaga. Por que? Comenta: Então, a gente fez, na verdade a gente fez mais coisa, não só isso. Mas a gente pegou a vela, tampou ela todinha com o copo, não passava 
mais nada ali, aí a chama se apagava. Você vai explicar por que a chama apaga depois que a gente coloca o copo em cima dela.

Professora: A terceira. Lê: $\mathrm{O}$ efeito estufa é um fenômeno natural do nosso planeta, que permite a vida em nosso planeta. Por que o efeito estufa é importante para manter a vida em nosso planeta? Comenta: Então, o que ele faz de importante que permite que a gente viva, a gente e os outros seres vivos que vivem aqui?

Professora: A quatro. Lê: O aquecimento global é um grande problema para o nosso planeta. Comenta: Na letra A, observando o desenho que mostra o planeta Terra, tem barcos, navios, carros, avião e muita fumaça aqui. Lê: Observando o desenho abaixo, como o ser humano contribui para o aquecimento global? Comenta: Então, o que que a gente faz que provoca esse aquecimento global, trazendo esse problema?

Professora: A B. Lê: Qual o gás que provoca o aquecimento global? Comenta: Vai dizer só um, tá? Vocês sabem que são mais de um, mas vai dizer só um, só um já serve. Não tá perguntando quais, então só um gás que provoca o aquecimento global, já tá até aí esse problema pra gente.

Professora: Na C. Lê: Cite... Comenta: então diga duas, nessa são duas, não uma. Lê: Cite duas medidas que você pode fazer para evitar o aquecimento global. Comenta: Então, o que que a gente pode fazer no nosso dia a dia, duas coisas que a gente pode fazer no dia a dia, pra gente não ter esse problema do aquecimento global.

(...)" (Notas do diário de campo e transcrição de audiogravação)

Apresentamos a leitura das quatro primeiras questões da prova pela professora. Depois, ela continua seguindo o mesmo esquema, lê o que está na prova e faz comentários. Vemos que a professora explica o que está sendo perguntado, contribuindo para que os alunos criem um sentido para as perguntas que dialogue com o sentido da professora. Ela faz isso dialogando com discursos de aulas anteriores, de outras interações que vivenciaram juntos. Os estudantes apenas ouvem a explicação da professora, a atividade responsiva que exercem é a da escuta. Mas, percebemos que participam da interação proposta quando um dos estudantes tenta falar e colocar sua voz na leitura do texto, e quando vários alunos tentam escrever logo depois da professora explicar a primeira pergunta. Isso mostra que estão lembrando dos experimentos que realizaram e logo querem escrever sobre ele.

No momento que lê as perguntas e discute seu sentido, a professora está atuando na mobilização dos sistemas de conhecimento dos estudantes para leitura e depois produção de textos. Assim, ativa o sistema de conhecimento de mundo ao relembrar as atividades que realizaram e trazer a lembrança de conceitos e conhecimentos que discutiram nas aulas e relacionar com objetos culturais que os estudantes conhecem. Faz isso, por exemplo, quando realiza a leitura da imagem da prova que os alunos devem interpretar, que se relaciona com a discussão feita na 
correção de exercícios escritos em aula anterior e traz para a interação objetos que eles conhecem, como barcos, navios, fumaça: "Na letra A, observando o desenho que mostra o planeta Terra, tem barcos, navios, carros, avião e muita fumaça aqui. Lê: Observando o desenho abaixo, como o ser humano contribui para o aquecimento global? Comenta: Então, o que que a gente faz que provoca esse aquecimento global, trazendo esse problema?". O sistema linguístico pode ser mobilizado e ampliado ao discutir o significado de determinadas palavras e questões gramaticais, por exemplo quando chama atenção para a concordância de número em “Qual o gás que provoca o aquecimento global? Comenta: Vai dizer só um, tá? (...) Não tá perguntando quais, então é só um gás que provoca o aquecimento global(...)" ou discute a palavra cite "Cite... Comenta: então diga duas(...) Lê: Cite duas medidas que você pode fazer para evitar o aquecimento global". O sistema de conhecimento interacional é mobilizado, por exemplo, quando a professora discute os objetivos das perguntas, que dizem respeito ao tipo de interação escrita que se espera dos alunos ao produzirem os textos das respostas, como na primeira questão "Você vai explicar por que o algodão sai seco nessa situação. Então por que que, o algodão que está dentro do copo, a gente mergulhou o copo, quando a gente levanta e mexe no algodão, ele tá seco? Vai explicar por que que isso aconteceu". Assim, estratégias sócio-cognitivas e sistemas de conhecimento vão sendo ativados pela professora para ajudarem os estudantes a lerem e escreverem. Dessa forma, a prova se torna um momento de ensinoaprendizagem de processos de leitura e de escrita. Outra professora investigada reflete sobre esse processo em sua fala "Olha, nas avaliações, nas provas, quando são provas longas, eu leio com eles. Principalmente quando eu vejo que eles estão com dificuldades para fazer a prova. Eu leio".

O processo de ensino-aprendizagem de leitura e escrita também acontece em momentos nos quais as professoras atendem os alunos individualmente, enquanto eles fazem as provas. Como no exemplo a seguir, no qual vemos a ativação do sistema linguístico de conhecimento para leitura e escrita de uma das questões da prova apresentada.

\footnotetext{
“- Uma aluna chama a professora e diz que não entendeu uma pergunta. A professora lê e explica a questão 4 para ela.

Estudante C: Contribui é ajudar, né?
} 
Professora: Contribui nesse caso não é uma coisa boa. Contribui no sentido de aumentar o aquecimento global.

- Muitos alunos chamam a professora, ela vai lendo as questões individualmente e explicando o enunciado. Eles têm dúvidas sobre o que está sendo solicitado nas questões". (Notas de diário de campo e transcrição de audiogravação)

O fato de muitos alunos chamarem a professora mesmo após a leitura coletiva mostra como ainda tem pouca autonomia para realização das atividades de leitura e escrita, precisando bastante do apoio da professora. Além disso, sugere que estão interagindo individualmente com os textos da prova e, nesse momento, sentem dificuldades na construção de sentidos. Ao dialogar com os alunos individualmente, a professora atua nos processos singulares de leitura e escrita de cada aluno que coloca suas dúvidas. Como mostra a fala na qual a professora comenta sobre como tenta solucionar as dúvidas dos alunos que aparecem durante a prova "E aí a gente faz... eu faço isso com eles. Vamos lá, lê aqui o que está pedindo. O que que você entendeu?".

Após a prova, em uma outra aula, a professora faz a correção coletiva da avaliação e, novamente, esse aparece como um momento de reflexão sobre atividades de leitura e de escrita. Como vemos a seguir, na correção das primeiras questões da mesma prova.

“- A Professora lê a questão 1 da prova. Explica a questão, conversando com uma aluna. Depois da discussão escreve a resposta no quadro. Diz que quase toda a turma acertou essa resposta.

Professora: O experimento. Vamos ver se vocês concordam ou não. Lê: No experimento feito no laboratório, colocamos um copo com algodão em seu fundo e uma vasilha cheia de água como está na imagem abaixo. Quando levantamos o copo vimos que o algodão saía seco. Explique por que o algodão saiu seco nessa situação.

Estudante A: Porque tinha ar.

Professora: Isso. O ar fica espremido lá dentro do copo e aí protege esse algodão, não deixa que a água entre nesse copo inteiro. Vocês lembram que a gente ia levantando devagarzinho o copo e aí saíam aquelas bolhas de ar? E aí quando saía todo o ar o que aconteceu com o algodão?

Estudante A: Molhou.

Professora: Molhou, porque não tinha mais o ar para proteger, aí molhou, tá? Então... A professora fala e escreve no quadro: Porque o ar que tinha dentro do copo não deixou a água entrar.

Estudante A: Mas assim, ela entra um pouquinho no copo, né professora? Mas não molha o algodão assim...

- Professora: A água até entra, mas não chega até lá no fundo do copo. O ar não deixa ela chegar até lá. 
- Professora continua a correção com toda turma. Ela vai corrigindo lendo a pergunta, explicando a pergunta e a resposta em diálogo com os alunos.

- Professora: Aí na segunda questão: no outro experimento, nesse aí a maioria acertou. Lê: No outro experimento acendemos uma vela e colocamos um copo sob a vela, como mostrado na imagem abaixo. Comenta: Acendeu, botou o copo, aí a vela apagava. Lê: Depois de um tempo observamos que a chama da vela se apaga, por quê?

Estudante B: Porque faltou oxigênio.

Professora: Teve uns que responderam que o ar acabou. Não era o ar, o ar tá lá, lá tem gás carbônico, tem gás nitrogênio, tem vapor de água... tá lá dentro... O que que acaba do ar que apaga a vela é o gás oxigênio. Acabar o ar eu coloquei meio certo.

Estudante A: Eu coloquei a vela se apaga porque o gás oxigênio acaba.

Estudante B: Eu botei assim, eu botei tudo. A vela apaga porque o gás oxigênio acaba.

Professora: Isso. Ela apaga porque para chama da vela ficar acesa, ela vai usando o oxigênio e vai transformando ele em gás carbônico. (...).

- Alunos conversam com a professora sobre a questão, trazendo outras reflexões.

Estudante C: Professora sabe o que que eu vou fazer um dia? Vou pegar uma planta e vou pegar um animal, vou botar num pote e vou olhar.

Professora: AAAAA. Mas vai botar a planta? Mas, tem que botar comida!.

Estudante C: Aí ele não morre, ele sobrevive.

Professora: É, se tiver essas coisas. Se for uma formiga ou um pequeno sobrevive.

Estudante $\mathrm{C}$ : $\mathrm{O}$ rato?

Estudante B: Se for o rato, o rato morre. Tá na apostila.

Professora: Se ele tiver sozinho. Se tiver uma planta ele sobrevive, só que tem que ter comida pra ele. (...)" (Notas do diário de campo e transcrição de audiogravação).

Na correção destas duas questões, percebemos que o diálogo se constrói em torno do texto da pergunta, da resposta que os alunos escreveram na prova e de interações vivenciadas em outras aulas. A professora constrói o conhecimento escolar em Ciências junto com os alunos enquanto lê e escreve a partir da correção da prova. Os alunos colocam as próprias vozes no diálogo com a professora e com os textos, trazendo novos questionamentos, a partir do que era discutido. Trazem para cadeia discursiva, por exemplo, textos que leram em aulas anteriores e que não estavam na prova "Professora sabe o que que eu vou fazer um dia? Vou pegar uma planta e vou pegar um animal, vou botar num pote e vou olhar". Também nessa atividade, estratégias e conhecimentos utilizados na leitura das perguntas são ativados e mobilizados, reforçando a visão da avaliação como um processo pedagógico formativo. 
Além do aspecto formativo, a correção das questões com os alunos destaca a possibilidade da avaliação como prática investigativa, como vemos no diálogo transcrito a seguir, na correção da questão 4 sobre o aquecimento global:

\begin{abstract}
“(...) Professora: É. Letra A. Lê: Observando o desenho abaixo. Como o ser humano contribui para o aquecimento global? Comenta: Então toda vez que a gente queima um combustível seja gasolina, seja o álcool, seja o diesel, o GNV, o gás que a gente liga o fogão. Então, toda vez que a gente queima alguma coisa, a gente joga para atmosfera o quê, que é muito ruim?"
\end{abstract}

Estudante A: "Carbônico".

Professora: É. O gás carbônico. Em um pouquinho mais de quantidade, não é? Aí causa a poluição do nosso ar, o aumento da quantidade de gás carbônico aumenta o efeito estufa e o nosso planeta fica muito aquecido, traz o aquecimento global. Como o ser humano contribui para o aquecimento global? Especialmente queimando combustíveis. Mas, onde estão esses combustíveis? Vocês colocaram aí, a fumaça dos carros. Mas, de onde surge a fumaça dos carros?

Estudante A: Combustíveis.

Professora: Dos combustíveis. Então, usando combustíveis como, gasolina, o diesel.

Professora escreve no quadro: Queimando combustíveis como gasolina, diesel que liberam gás carbônico". (Notas do diário de campo e transcrição de áudiogravação)

Percebemos que o erro dos alunos é trazido para o diálogo pela professora ("Vocês colocaram aí, a fumaça dos carros") e é utilizado como fonte para construção do saber envolvendo a escrita da resposta ("Mas, de onde surge a fumaça dos carros? (...) Professora escreve no quadro: Queimando combustíveis como gasolina, diesel que liberam gás carbônico"). A avaliação pode ser compreendida aqui como uma prática investigativa e formativa.

\title{
4.3.3.1.
}

\section{Avaliação e processos de escrita}

Outro aspecto importante a ser considerado na comparação entre a "prova da prefeitura" e a "prova da professora" é o tipo de resposta exigida. A "prova da prefeitura" era de múltipla escolha, enquanto a da "professora" era discursiva. Assim, enquanto na avaliação externa os estudantes só exploravam a leitura, na avaliação elaborada pela professora, exigia-se também a produção textual. Duas professoras produziam suas provas de forma discursiva e uma elaborava provas de 
múltipla escolha. Ao refletir sobre a escolha pela prova de múltipla escolha, a professora falou que não se sentia satisfeita, mas não sabia como lidar com as dificuldades de leitura e de escrita dos alunos, que as impediam de fazer uma prova discursiva.

\begin{abstract}
“(...) porque os meus alunos simplesmente não liam. Eles não liam as questões. Eles além de reclamar, eles não liam e tinham também muita dificuldade de escrever, de formular questões discursivas. Então eles deixavam em branco, eles nem tentavam escrever.(...) Então eu acabei tendo que recuar (...) Mas não me sinto ainda satisfeita. Tem as turmas de sexto ano, que você acompanhou, eu nem tento colocar questões discursivas. Se eu for tentar fazer isso é num exercício, mas numa avaliação eu sei que vai ser muito complicado." (Fala de uma das professoras investigadas).
\end{abstract}

Outra professora, em relação à opção pela prova discursiva, colocou que “(...) as minhas provas geralmente têm bastante questões discursivas e eu procuro não fazer só questões muito diretas. (...) Eu passo questões que eles tenham que refletir e construir respostas". Nesse caso, a prova se torna um momento de ensinoaprendizagem de leitura e também de escrita.

Em relação às questões que exigiam a escrita, algumas delas permitiam uma produção mais autoral que outras. Na prova que apresentamos, havia questões abertas que solicitavam que os estudantes explicassem o que observaram nos resultados de uma experimentação ("Explique por que o algodão saía seco nessa situação" ou "Depois de um tempo observamos que a chama da vela se apagava. Por que?); outras que pediam que discutissem de forma escrita a importância de determinados fenômenos para manutenção da vida (efeito estufa e camada de ozônio); e ainda uma que demandava que interpretassem uma imagem. Dentre as abertas, havia também as que tentavam trazer questões cotidianas para produção escrita, como a que pedia que citassem medidas que eles próprios poderiam fazer para evitar o aquecimento global, ou ainda a que solicitava que explicassem a importância de lavar as mãos. Estas perguntas abertas estimulam a autoria dos estudantes, pois permitem que escrevam com estilo próprio e produzam textos com diferentes formas de interação. Ao mesmo tempo, há uma restrição dessa individualidade, visto que se espera que os textos produzidos se aproximem do gênero científico escolar, que limita as possibilidades de criação individual. Como diz Bakhtin, alguns gêneros discursivos permitem mais que apareça a individualidade do enunciatário que outros. O gênero científico escolar, como se 
articula aos gêneros científicos, exige que se usem determinados termos e se escreva de certa forma, assim a individualidade não aparece tanto. Mas, pela maneira como as perguntas foram construídas, mesmo que os estudantes precisem utilizar o gênero científico escolar, podem usá-lo de variadas maneiras. Na mesma prova há outras questões que restringem mais a autoria, ao exigirem respostas de apenas determinados termos, como as perguntas: "Qual o gás da atmosfera que as plantas usam para fazer a fotossíntese?" ou "Qual o gás da atmosfera que as plantas e os demais seres vivos usam em sua respiração?" ou ainda "Em qual camada da atmosfera nós vivemos?".

Por fim, analisando as provas elaboradas pelas professoras, percebemos que congregam diferentes tradições curriculares do ensino de Ciências. No exemplo de prova apresentado, grande parte das questões são acadêmicas, como as que envolvem experimentação, as que discutem aquecimento global, camadas da atmosfera, troca de gases pelos seres vivos e pressão atmosférica. Mas, há uma questão utilitária e pedagógica, que pergunta sobre a importância de lavar as mãos. Assim, nas avaliações, as crianças leem e escrevem em articulação às diferentes tradições curriculares da disciplina escolar Ciências.

Em síntese, as avaliações formais elaboradas pelas professoras funcionam nas aulas de Ciências também como atividades que envolvem processos de ensinoaprendizagem de leitura e escrita. Nestas atividades, as professoras fazem mediação da interação entre os textos das perguntas e os alunos, ativando estratégias e sistemas de conhecimento para a leitura e para a escrita. Além disso, intervêm nos processos singulares dos alunos na relação com a linguagem escrita enquanto fazem as provas, e dialogam sobre seus erros e acertos na correção coletiva, refletindo sobre o que leram e escreveram. As avaliações que as professoras desenvolvem, a partir do cotidiano escolar, aumentam a possibilidade de criação de sentidos para o que os estudantes leem e escrevem, pois partem de interações que vivenciaram nas aulas.

Outras atividades pedagógicas envolvendo a linguagem escrita foram observadas nas aulas de Ciências, como, por exemplo, a cópia de textos que as professoras colocavam no quadro com exercícios escritos associados, exercícios escritos do livro didático, um trabalho de resumo de textos da revista de divulgação científica "Ciência Hoje das Crianças", desenho e escrita em tópicos de características das camadas da atmosfera, entre outros. Para finalizar este capítulo 


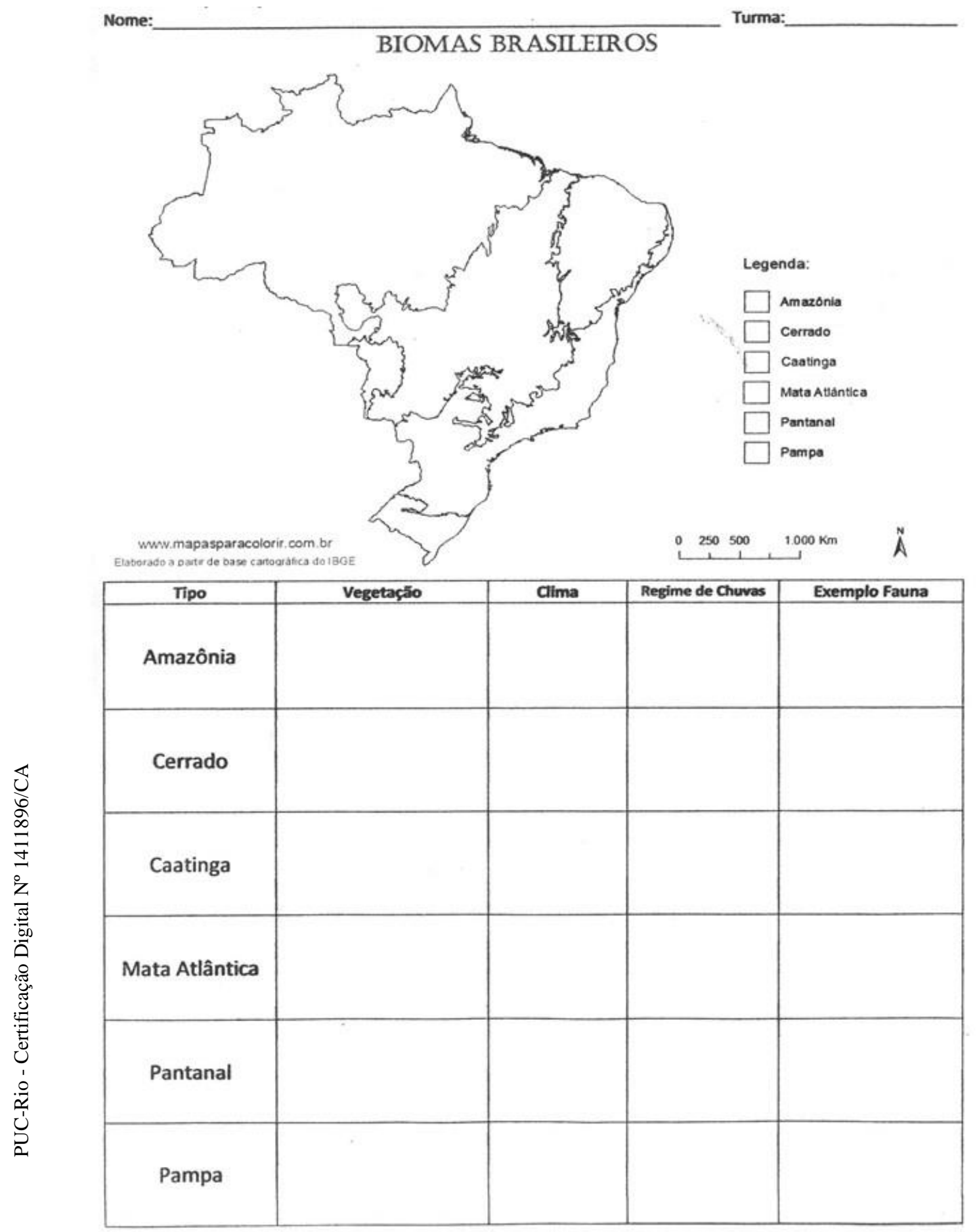

FIGURA 21: Roteiro para estudo dirigido elaborado pela professora de Ciências de uma turma de sexto ano do ensino fundamental de 2016 de uma escola municipal do Rio de Janeiro.

O material funcionou como um estudo dirigido. As crianças precisavam buscar informações em diferentes gêneros (fotos, tópicos dos slides e fala da professora) para produzirem um texto escrito na tabela e lerem um mapa do Brasil, localizando os biomas. Assim, destacamos inicialmente a multimodalidade que a 
atividade congregou, que envolveu vários modos diferentes de representação e a necessidade de articulá-los, como a professora explicou para os estudantes na aula:

"Professora: Então, o que a gente vai fazer pessoal? A cada bioma que a gente for passando a gente vai completando essa tabelinha. A gente vai colocar a vegetação, o clima, o regime de chuvas e um exemplo de espécie animal. Quando eu falo vegetação eu quero que vocês me expliquem a vegetação. Eu vou explicar aqui e vocês vão escrever, tá? Se a vegetação é uma floresta tropical densa, ou se é um campo aberto, ou tem árvores pequenas, ou árvores grandes, eu quero que vocês me contem como é a vegetação. No clima, eu quero que vocês me digam se é um clima quente e úmido, se é um clima quente e seco, se é um clima semiárido, tá? Eu vou

explicando o que é cada clima desses. No regime de chuvas vocês vão dizer sobre a pluviosidade, o que que é a pluviosidade? Pluviosidade é a quantidade de chuva no ano. Eu quero que vocês me digam se a pluviosidade é alta, se a pluviosidade é baixa, se a pluviosidade é alta no verão, se a pluviosidade é alta no inverno. Isso tudo eu vou falar. E a espécie animal, que quero que vocês coloquem três espécies de animais daquela região. Tá bom?” (Transcrição de audiogravação)

Inicialmente, os estudantes tiveram bastante dificuldade para fazer a atividade. Dionísio (2008) destaca na discussão sobre ensino de gêneros multimodais que é importante que o professor esteja consciente de que uma aula ministrada com uso de slides com fotos, textos escritos e exercícios exige do estudante uma atividade bastante complexa. Isso porque espera-se que o estudante processe diferentes práticas de letramento, integrando variados modos de representação e buscando dessa forma construir sentido para o texto oral da fala da professora, para o texto escrito dos tópicos, para o texto visual das imagens e fotos, e, finalmente, para o seu próprio texto. Percebendo a dificuldade que os estudantes enfrentavam, a professora atuou na mediação dos processos de leitura e escrita desenvolvidos, ajudando-os a preencherem a primeira coluna da tabela.

“(...) Professora observa se os alunos estão escrevendo. Percebe que a maioria não está preenchendo nada. (Realmente parecem ter dificuldades em extrair informações do slide para a tabela).

Professora: Tá todo mundo preenchendo as tabelas?

Estudantes: Sim

Professora: Eu tô vendo um monte de tabela em branco.

Estudante C: Ué, é pra fazer?

Estudante B: Já até acabei, professora! 
- Ao perceber que os alunos não preencheram a parte da Amazônia, a professora decide ajudar e volta os slides.

Professora: Pessoal, vou voltar o slide pra preencher a tabela. Ei. Atenção! Qual é o clima, galera, da Amazônia?

Estudantes (coro): Quente e úmido (leram no slide).

Professora: O clima é quente e úmido.

- Com a professora explicando devagar, os alunos começam a preencher a tabela.

Professora: Só vou ajudar nessa primeira, o resto é por conta própria. O Clima é quente e úmido. Regime de chuvas? Alta pluviosidade.

Estudante A: Pode botar muita chuva?

Professora: Muita chuva. Pode botar muita chuva.

Estudante B: Como é que se escreve essa palavra?

Professora: Tá aqui no quadro. Todo mundo já escreveu?

Estudante C: A vegetação?

Professora: A vegetação, como é que é pessoal?

Estudante B: Muita vegetação

Professora: Floresta densa, com várias árvores.

Estudante C: Acertei!

Professora: Ou vocês podem colocar só floresta tropical

Estudante A: Eu botei floresta densa, com árvores altas, com folhas largas e sempre verdes.

Professora: Parabéns. Vegetação, floresta densa, árvores altas, folhas largas e sempre verdes.

(...)" (Notas do diário de campo e transcrição de audiogravação)

Depois dessa discussão, os estudantes conseguiram ter mais autonomia para preencherem o material, escrevendo as características dos biomas em diálogo com a professora.

“- A Professora começa a discutir o Cerrado. Depois da ajuda com a Amazônia, já começam a preencher a tabela do Cerrado, acompanhando a explicação da professora.

Professora: Galera, o Cerrado, é o segundo maior bioma do Brasil, e ele fica aqui na região central do Brasil. O Clima é quente e tem muita chuva no verão, e o inverno é muito seco. Então, a chuva no Cerrado ela não é alta nem baixa, ela é média e fica concentrada no verão. (...) Quente, chuvoso no verão, e inverno seco. Mas esse chuvoso não é chuvoso igual na floresta amazônica que chove todo dia não, é um chuvoso que chove um pouquinho, tem chuvas regulares.

Estudante B: Ontem caiu um dilúvio aqui

Professora: Ontem caiu um dilúvio aqui, né?

Estudante D: A gente quase não subiu

- Professora espera um pouquinho para eles preencherem a tabela. 


\section{(...)}

Professora: Como que é a vegetação no Cerrado? Ela é um pouco diferente no inverno e no verão. (...) Elas são plantas adaptadas a clima de seca, elas têm folhas formando espinhos. Todo mundo conhece cactos?

Estudantes: sim.

(...)" (Notas do diário de campo e transcrição de audiogravação)

A aula segue. A professora descreve os ambientes e mostra fotografias, dialoga, espera os alunos escreverem, confere quem conseguiu escrever e tira dúvidas individuais. Após preencherem a tabela, a professora orienta os estudantes a fazerem a parte do mapa do Brasil, associando os biomas à legenda.

\footnotetext{
“- A professora explica o que fazer com o mapa da folhinha, depois da tabela estar preenchida. Explica como devem relacionar o mapa com a legenda.

Professora: Pessoal, que que vocês vão fazer agora? Agora vocês vão tentar pintar esse mapa, e vocês vão colocar a legenda do lado. Por exemplo, eu vou voltar lá na imagem do início para vocês copiarem, a região amazônica, vocês podem pintar de verde, e aí esse quadrinho da Amazônia vocês tem que pintar ele de verde também pra fazer a legenda, tá? E aí a caatinga, por exemplo, vocês podem pintar de laranja...

Estudante B: Eu vou pintar de rosa

Professora: Aí vai ter que pintar o quadradinho da Caatinga de rosa.

- Professora dá um tempo para os alunos preencherem o mapa. Enquanto eles pintam o mapa, ela circula ajudando-os individualmente com o mapa e a tabela". (Notas do diário de campo e transcrição de audiogravação)
}

Os alunos precisam bastante da orientação da professora, pois têm dificuldade para realizar a atividade de pintar o mapa e preencher a tabela. Pressionada pelo tempo, a professora não consegue corrigir a atividade com eles e aprofundar os processos pedagógicos que estavam sendo realizados.

Mais uma vez, percebemos uma atividade do ensino de Ciências que possibilitou processos de ensino-aprendizagem de leitura e de escrita. Diferentes estratégias e sistemas de conhecimento foram mobilizados pela professora para que os alunos interagissem com a linguagem escrita na aula de Ciências. Por exemplo, ativação do sistema de conhecimento de mundo, no reconhecimento do mapa do Brasil, a ampliação do sistema de conhecimento linguístico, na discussão dos nomes dos biomas e do termo pluviosidade, e a mobilização do sistema de conhecimento interacional, na aprendizagem do gênero tabela e legenda do mapa, entre outros. Os resultados da atividade parecem ter sido limitados pelo tempo para sua realização. 
Poderíamos mostrar e discutir ainda muitos outros exemplos de atividades pedagógicas observadas nas aulas de Ciências que permitiram interações com a linguagem escrita e processos de ensino-aprendizagem de leitura e de escrita, refletindo sobre os conhecimentos produzidos e os limites que foram sendo estabelecidos. Porém, afirmamos que as metodologias e técnicas empregadas já foram descritas ao ponto de saturação. Assim, chegamos ao momento da escritura de uma síntese das reflexões que construídas. No próximo capítulo, elaboramos então as considerações finais. 


\section{5 \\ Considerações finais}

"Parece que tudo que nós estudamos,
atualmente, está no campo das
incertezas."

(Isabel Lima, em um diálogo informal via aplicativo WhatsApp com a nossa turma de doutorado - coorte 2014).

Chegamos enfim às considerações finais, após percorrer um longo caminho, que se iniciou com as primeiras reflexões sobre a desigualdade no acesso à leitura e à escrita, que trouxemos de nossas vivências como professora, e a escolha de estudar, sistematizar e aprofundar esses questionamentos por meio do doutorado em Educação. Passamos pelas aulas, discussões, teorias, pensamentos, observações, diálogo com as professoras e os alunos nas escolas, uma explosão de novas reflexões, análises dos dados e, finalmente, a escritura desta tese e a produção dos conhecimentos que aqui expomos.

$\mathrm{Na}$ investigação que realizamos, estudamos as contribuições das aulas de Ciências para o ensino-aprendizagem da leitura e da escrita, especialmente em atividades pedagógicas vivenciadas cotidianamente nesta disciplina escolar. Reconhecemos a importância da linguagem escrita para a interação com diversas práticas sociais que nos cercam nas sociedades grafocêntricas atuais (SOARES, 2007). Assim, afirmamos que processos de ensino-aprendizagem de leitura e escrita compõem uma finalidade central da instituição escolar e de seus variados espaçostempo, incluindo as aulas de Ciências. Acreditamos que outras disciplinas escolares também tenham um papel importante no ensino-aprendizagem da linguagem escrita, mas neste trabalho de pesquisa focamos na disciplina Ciências. Buscamos entender quais são as possibilidades de trabalho nesta disciplina na aquisição das habilidades de leitura e de escrita. Nesse contexto, estudamos as articulações entre as aulas de Ciências e o acesso à linguagem escrita. $\mathrm{O}$ objetivo principal de nossa pesquisa foi compreender as relações que se estabelecem entre atividades pedagógicas das aulas de Ciências e processos de leitura e/ou escrita que os estudantes vivenciam nelas.

O campo empírico da pesquisa incluiu três fontes de dados analisados qualitativamente: observações de aulas de Ciências (com diário de campo e audiogravação); entrevistas semiestruturadas com as professoras e estudantes das 
turmas observadas; e análise dos principais materiais didáticos utilizados nas aulas (Cadernos Pedagógicos, roteiros didáticos elaborados pelas professoras e avaliações formais). As observações foram realizadas nas aulas de três professoras de Ciências em três turmas de sexto ano de três escolas municipais de regiões bem diferentes da cidade do Rio de Janeiro, em busca de maior diversidade de práticas pedagógicas.

Utilizamos a perspectiva sociointeracionista de linguagem, embasando-nos no pensamento de Bakhtin (2016; 2003; BAKHTIN - VOLOCHÍNOV, 1990), e as posteriores contribuições de Koch (2003), Koch e Elias (2015 e 2017) assim como outros autores do campo. A partir dessa concepção, entendemos que a linguagem é constitutiva do sujeito. É através dela que as interações sociais se estabelecem, que realizamos nossas atividades e que nossa consciência se desenvolve. Todos os campos de atividade humana se relacionam com o uso da linguagem e, assim, produzem e são produto da dela. Isso inclui, é claro, as atividades que acontecem na escola. Estudamos a escola como um espaço de linguagem e do dialogismo. Analisamos os diálogos que acontecem nas relações entre as professoras, seus estudantes e os textos selecionados e produzidos nas aulas de Ciências.

Trabalhamos com a compreensão das atividades de leitura e escrita como interação social. Nesse sentido, o texto é visto como um lugar de interação e de constituição de interlocutores que, dialogicamente, se constroem e são construídos no texto. O sentido do texto é elaborado na interação texto-sujeitos e não existe antes dessa interação. Nessa concepção, a leitura é entendida como um processo estrategista complexo, no qual o sujeito mobiliza seus sistemas de conhecimento e realiza uma série de estratégias para dar sentido ao que lê. Esses conhecimentos dizem respeito ao próprio código linguístico, mas além dele, engloba as experiências e outros conhecimentos do leitor. A escrita por sua vez, é entendida como uma atividade na qual o produtor do texto, para escrever, imagina um leitor e estabelece com ele uma interação. Assim, realiza várias estratégias e ativa seus sistemas de conhecimento para escrever um texto que faça sentido para ele mesmo e para o seu leitor. Em nossa pesquisa, refletimos sobre os processos de leitura e escrita que os estudantes vivenciam na disciplina Ciências, estudando as estratégias e sistemas de conhecimento que são mobilizados em processos de negociação entre os estudantes, as professoras e os textos que são lidos ou produzidos nas aulas. 
As professoras que participaram da pesquisa reconhecem a centralidade da linguagem escrita nas aulas de Ciências ao discutirem que estão sempre refletindo sobre a leitura e a escrita de seus alunos em seu fazer pedagógico, quando conferem materiais escritos que os estudantes produzem, nas avaliações que realizam e nas discussões com outros docentes sobre as dificuldades que os estudantes vivenciam nessas atividades. A análise das entrevistas das professoras e as observações das aulas mostraram que elas mesclam diferentes concepções sobre os processos de leitura e de escrita. Estas se aproximavam do entendimento da leitura e da escrita com foco no texto, outras vezes com foco nos sujeitos e outras vezes ainda com foco na interação social. O foco no texto vem da ideia de língua como sistema fechado, como estrutura ou como código. Nesse sentido, o texto seria o produto da codificação de um emissor. Para escrever é preciso apenas saber utilizar o código com clareza, enquanto para ler é necessário simplesmente decifrá-lo $(\mathrm{KOCH}, 2003$; KOCH e ELIAS, 2015 e 2017). Essa concepção apareceu quando as professoras mencionaram dificuldades de leitura e escrita dos alunos focando nas questões gramaticais. Concepção com foco no sujeito se relaciona à ideia de escrita como expressão do pensamento e leitura como o entendimento das intenções e da representação mental do autor. Envolve uma visão de sujeito individual, psicológico e dono de sua vontade (KOCH, 2003; KOCH e ELIAS, 2015 e 2017). $\mathrm{Na}$ pesquisa realizada, percebemos essa concepção quando as professoras falaram sobre dificuldades dos alunos em interpretarem os textos, mostrando que incluem os sujeitos na reflexão sobre leitura. A concepção sociointeracionista de leitura e escrita apareceu na fala de que a escrita depende da interação social vivenciada pelos alunos, por exemplo, nas atividades de experimentação. Em relação às práticas pedagógicas de leitura e escrita realizadas, estas também variaram, associadas às diferentes concepções. As práticas de leitura em alguns momentos envolveram a centralização desta atividade e determinação de um sentido único pela professora, e, em outros, aconteceu uma leitura mais aberta, que envolvia muitos diálogos e interações com o texto. Em relação às atividades envolvendo a escrita, em alguns momentos se limitaram a cópias do quadro e em outros à produção de textos com cunho autoral. Destacamos a importância da elaboração de reflexões sobre as concepções de leitura e escrita que têm circulado na escola, de forma a construir novas possibilidades de ensinar e aprender a ler e a escrever (SILVA, 1999). Os estudantes também reconheciam que as aulas de Ciências podiam 
contribuir para a aprendizagem da linguagem escrita. A concepção que possuíam desses processos se aproximava da ideia de leitura como a capacidade de decifrar um determinado código e de escrita como a correta utilização desse código. Assim, em diálogo com Koch e Elias (2015 e 2017), interpretamos que traziam uma concepção com foco no texto.

As professoras e estudantes refletiram sobre dificuldades vivenciadas em processos de leitura e escrita nas aulas de Ciências. Os alunos falaram sobre dificuldades associadas à densidade lexical da linguagem do ensino de Ciências, mencionando as palavras difíceis que aparecem e o estranhamento que sentem ao tentarem dar sentido a esses termos em momentos de aprendizagem. As professoras trouxeram reflexões sobre as dificuldades para a realização de trabalhos específicos de leitura e de escrita associadas a lacunas na formação docente, destacando que sem saber como lidar com problemas de letramento linguístico dos alunos, buscam experiências de suas histórias como alunas e saberes que desenvolveram ao longo da trajetória como docente. Discutiram, ainda, obstáculos relacionados a questões estruturais, especialmente a falta de recursos (como livros, possibilidade de cópias de textos, salas de leitura, entre outros), a organização da escola determinada pela Secretaria Municipal de Educação do Rio de Janeiro (grande número de alunos por turma, sistema de aprovação/reprovação pouco transparente e falta de investimento na formação continuada dos professores) e o controle do trabalho docente, que limita o tempo pedagógico e a construção de atividades de acordo com os contextos locais.

As observações nos permitiram perceber a escola como um espaço de interação social e linguístico - um espaço de natureza dialógica. Vimos que as aulas de Ciências eram constituídas por diálogos que ocorriam nas interações sociais entre os estudantes, entre eles e as professoras, entre as professoras, os estudantes e os textos escritos e destes com as aulas e textos utilizados anteriormente. Em todas as aulas observadas, ocorreram interações com textos escritos e estas foram centrais para os processos pedagógicos desenvolvidos. Assim, observamos que muitos diálogos se estabeleciam nas aulas de Ciências através da leitura e/ou da escrita de textos, de forma que interações sociais aconteciam por meio da linguagem escrita e tornavam as aulas de Ciências um espaço-tempo também para ler e escrever. Percebemos que o fato de as professoras estarem a todo tempo trabalhando com textos escritos faz com que precisem desenvolver estratégias para que os alunos 
leiam e escrevam e, assim, acabam se dedicando a processos de ensinoaprendizagem de leitura e de escrita em suas aulas. Nesse sentido, defendemos que as aulas de Ciências sejam pensadas também como espaço de ensino-aprendizagem da linguagem escrita.

Nas aulas, as professoras realizavam a mediação da interação dos alunos com os textos. Nesta mediação, estabeleciam diálogos com os estudantes a partir dos textos, contribuindo para que dessem sentido ao que liam e/ou escreviam. Percebemos que o dialogismo nas aulas de Ciências se constituía especialmente com e a partir de textos escritos, utilizados para a construção do conhecimento escolar em Ciências. A mediação das professoras era importante para que os alunos pudessem dar sentido aos textos das aulas de Ciências, considerando a complexidade envolvida em muitos deles, devido aos termos específicos e às características da linguagem científica. As professoras e os estudantes traziam elementos de seu dia-a-dia para os diálogos, realizando uma articulação entre conhecimentos cotidianos e científicos na produção do conhecimento escolar em Ciências, o que aparecia também na mistura de elementos característicos de gêneros discursivos primários e de gêneros secundários.

Nos diálogos, havia, primeiramente, uma simplificação de gêneros secundários dos textos escritos em gêneros primários, quando a professora e os alunos traziam questões cotidianas simples para o diálogo oral que estabeleciam. Depois, ocorria uma nova complexificação dos gêneros primários em gêneros secundários, quando retornavam às atividades de produção ou de leitura dos textos. Nessa articulação entre os gêneros, a linguagem escrita ia se desenvolvendo em interação com os estudantes. Vimos predominância do gênero secundário nos momentos em que as professoras centralizavam a leitura em torno dos textos, sem dialogarem com os alunos sobre o que liam. Assim também acontecia em atividades nas quais as demandas de escrita eram curtas, fechadas e objetivas ou eram apenas cópias, sem articulação com gêneros primários. Nestas, as vozes dos alunos apareceram menos e as possibilidades de interação com os textos diminuíram. Assim, percebemos que quanto mais as vozes dos estudantes eram trazidas para o diálogo, mais profundamente as interações com a linguagem escrita eram vivenciadas e maior o potencial de ensino-aprendizagem de leitura e/ou de escrita. Esse processo acontecia em associação com as diferentes tradições curriculares do 
ensino de Ciências, isto é, acadêmicas, utilitárias e pedagógicas. Os diálogos foram observados em diferentes atividades pedagógicas.

Para entender as atividades observadas nas aulas de Ciências, dialogamos também com o enfoque sócio-histórico das disciplinas escolares, principalmente a partir de Goodson (1995, 1997 e 2001). A constituição e as trajetórias das disciplinas escolares são influenciadas por variados fatores culturais, sociais, econômicos, históricos e políticos das comunidades científicas, das instâncias produtoras de materiais didáticos, do governo, das instituições escolares, da vida dos professores e alunos, entre outros contextos. Disputas por recursos e status nesses âmbitos produzem estabilidades e mudanças nos currículos das disciplinas escolares, que acabam por afetar o que vemos hoje nos conteúdos e metodologias que aparecem nas aulas.

Observamos diversas atividades pedagógicas envolvendo leitura e/ou escrita nas aulas de Ciências, mas as de maior frequência foram aquelas em que os Cadernos Pedagógicos eram usados. Esses materiais concretizam os textos curriculares da Secretaria de Educação e, atrelados às avaliações externas, guiam o trabalho realizado nas escolas (LUZ, 2016). Em nossa investigação, percebemos que os Cadernos norteavam os trabalhos desenvolvidos, especialmente em relação aos conteúdos e à ordem em que eram abordados, de forma que também influenciavam os processos de ensino-aprendizagem de leitura e de escrita realizados. Por outro lado, as professoras colocaram em suas entrevistas que buscam formas de resistência ao controle exercido pelos Cadernos e pelas avaliações externas, trazendo outras atividades para a sala de aula e utilizando estes materiais de maneiras variadas, ressignificando-os para os alunos.

A análise dos Cadernos Pedagógicos mostrou que são compostos por diferentes gêneros discursivos. Predominaram textos pertencentes ao que denominamos de gênero científico escolar, formado por enunciados informativos que têm por objetivo explicar conceitos associados às ciências de referência da disciplina escolar Ciências. Caracterizavam-se principalmente por aspectos relacionados à linguagem científica, como nominalização dos processos e ausência de narradores, conjugados a pequenos trechos com elementos da linguagem comum. Textos deste gênero eram associados principalmente a tradições acadêmicas, mas dialogavam também com tradições pedagógicas e/ou utilitárias. Encontramos também textos escritos do gênero discursivo que chamamos de gênero 
informativo com questões sociais. Estes textos traziam questões culturais (não científicas) com o objetivo de contextualizar conhecimentos científicos com outros aspectos da sociedade. Identificamos também uma grande quantidade de imagens (fotografias, esquemas e ilustrações), que tinham diferentes funções. Apoiavam explicações de conceitos articulados a conhecimentos científicos, ajudavam na caracterização das paisagens e dos seres vivos, traziam elementos cotidianos para o diálogo e motivavam interações com os textos escritos. Havia ainda textos dos gêneros discursivos gráfico, notícia de jornal, tabela, mapa, história da ciência, exercício escrito de síntese e proposta de experimentação escolar. Todos esses gêneros se articularam às tradições acadêmicas, pedagógicas e utilitárias da disciplina Ciências, ao trazerem conceitos científicos das ciências de referência em diálogo com discussões de aspectos sociais e propostas de metodologias didáticas. Atividades de leitura e de escrita ocorreram em associação aos variados gêneros e nos levaram à reflexão sobre as aulas de Ciências como um espaço de configuração multimodal, por permitir o acesso a diversos gêneros discursivos.

O estudo dos Cadernos Pedagógicos mostrou ainda a superficialidade dos textos destes materiais, sempre curtos e rasos. As demandas de produção textual dos Cadernos eram objetivas, fechadas e diretas. Assim, não permitiam o desenvolvimento da autoria ou o aparecimento do estilo próprio de cada estudante, de forma que os sentidos possíveis ficavam restritos e as perguntas apenas estimulavam a repetição de informações. Os Cadernos, ao determinarem a homogeneização do currículo para toda a rede municipal, deixavam pouco espaço para o estabelecimento de vínculos com os diferentes contextos das escolas e dos estudantes. As professoras tentavam romper com essa normatização na forma como utilizavam os textos dos Cadernos, fazendo a mediação da interação entre estes e os estudantes.

Para isso, estabeleceram diálogos trazendo as vozes dos alunos para a construção de sentidos na interação com os textos dos Cadernos. Nesse processo, as professoras mobilizavam diferentes estratégias para que os estudantes realizassem as atividades de leitura. Dentre as estratégias observadas, estava a análise do título dos textos, criando antecipações e elaborando hipóteses sobre os mesmos, e o desenvolvimento de discussões sobre o tema dos textos antes da leitura em si, trazendo elementos da vida dos alunos para interação e formulando novas antecipações e hipóteses. Depois, ao longo da leitura dos textos, as professoras 
traziam as vozes dos estudantes para darem sentido ao que estavam lendo, criando relações com aspectos sociais, culturais e cotidianos, construindo conexões entre os textos e as experiências e vivências fora da escola e/ou em aulas anteriores. Outras estratégias envolveram a discussão de sentidos de termos e conceitos, a análise das fontes dos textos e articulação entre textos escritos e imagens lidas. Dessa forma, as professoras faziam os estudantes acessarem suas bagagens sócio-cognitivas e trazerem-na para a interação com os textos lidos, ativando e ampliando seus sistemas de conhecimento, estimulando a criação de sentidos e potencializando suas possibilidades de leitura. As observações mostraram que os Cadernos permitiram, principalmente, a realização de atividades de leitura, visto que as propostas de escrita eram muito fechadas e simples, deixando pouco espaço para autoria e para complexificar as produções textuais.

Outras atividades pedagógicas observadas que se articulavam a possibilidades de leitura e, especialmente de escrita, foram as experimentações didáticas. Aulas com a realização de experimentos aconteceram em diferentes momentos. Nas entrevistas com os estudantes, as experimentações apareceram em lembranças prazerosas das aulas de Ciências, marcando a identidade desta disciplina escolar. Várias falas destacaram aspectos motivacionais relacionados a estas atividades, que influenciaram processos de leitura e de escrita associados a elas, realizados com maior envolvimento dos alunos.

As professoras e os estudantes destacaram nas entrevistas o potencial de aulas com experimentação para desenvolvimento de processos de ensinoaprendizagem da linguagem escrita, principalmente por possibilitarem a leitura e a escrita a partir da interação com aquilo que realizaram e observaram concretamente, como colocou uma aluna "Porque a gente vê o que a gente escreve". Refletindo sobre essa questão, as professoras ressaltaram que os estudantes escrevem melhor em aulas com experimentos que em outras atividades.

Diálogos e atividades de escrita foram realizados em diferentes etapas da experimentação, incluindo a discussão dos objetivos do experimento, o levantamento de hipóteses, descrição do que foi observado e explicação para o resultado utilizando modelos científicos. Nos diálogos estabelecidos, as professoras traziam as vozes dos estudantes para reflexão sobre os experimentos, aumentando a possibilidade que escrevessem sobre eles. Nesse processo, sistemas de conhecimento dos estudantes foram mobilizados para que pudessem interagir com 
os experimentos e depois escrever sobre eles. Durante as atividades de escrita sobre a experimentação, diferentes estratégias foram acessadas, como revisão do que escreveram, reescrita, etc., em diálogo com a professora. $\mathrm{O}$ potencial da experimentação para processos de ensino-aprendizagem de leitura e escrita foi limitado por questões estruturais, relacionadas ao pouco tempo pedagógico disponível para realização deste tipo de atividade, à falta de recursos para produção de cópias de roteiros e compra de materiais, e pela forma como o diálogo foi estabelecido, com maior ou menor aparição das vozes dos alunos.

Outro tipo de atividade pedagógica observada nas aulas que se associaram a processos de leitura e de escrita foram as avaliações formais. Foram observados dois tipos de avaliações formais, as avaliações externas ("prova da prefeitura") e as avaliações internas ("prova da professora"). Estas apresentaram características bastante diferentes e possibilitaram atividades de leitura e/ou de escrita distintas. As avaliações externas eram padronizadas e dessa forma se afastavam dos contextos locais, diminuindo a possibilidade de interação dos estudantes com os textos escritos avaliativos, visto que não consideravam as interações que os estudantes vivenciaram nas aulas e nem suas experiências e conhecimentos. Ao desconsiderarem a singularidade dos processos pedagógicos vivenciados por cada turma, reduziam a possibilidade de os estudantes construírem sentido para o que liam, já que a leitura depende que os leitores levem para interação com o texto seus conhecimentos, suas reflexões, sua história, sua vida. Além disso, as avaliações externas pressionavam o currículo escolar e o tempo pedagógico, reproduzindo conteúdos padrões e diminuindo o tempo possível de realização de trabalhos formativos para leitura e escrita e investimento individualizado na relação de cada estudante com a linguagem escrita. As avaliações internas, diferentemente, eram elaboradas pelas professoras, a partir do que vivenciaram com os estudantes nas aulas. Dessa forma, os alunos, na interação com os textos avaliativos, puderam lembrar de experiências que tiveram nas aulas de Ciências e ler e produzir textos a partir delas, facilitando a criação de sentidos. Assim, as avaliações externas funcionaram como uma prática avaliativa classificatória, enquanto as avaliações internas puderam funcionar também como atividade investigativa e formativa, atuando no ensino-aprendizagem da leitura e da escrita.

As professoras utilizaram as avaliações internas para realização de diferentes atividades, como a leitura da prova com a turma, a discussão de dúvidas 
individualmente e a correção coletiva destes materiais. Nessas atividades, processos de ensino-aprendizagem da linguagem escrita aconteceram. Nos momentos em que liam as perguntas da prova e discutiam seu sentido, as professoras contribuíam para a ativação de estratégias sócio-cognitivas e a mobilização dos sistemas de conhecimento dos alunos para leitura do texto. Ao dialogarem com os alunos individualmente, as professoras atuavam nos processos específicos de leitura e escrita de cada um que colocava suas dúvidas. Na correção das provas, as professoras dialogavam com os alunos trazendo questões cotidianas e vivências das aulas, novamente ativando estratégias e mobilizando conhecimentos para que os estudantes interagissem com as questões da prova e os textos que eles mesmos produziram.

Em síntese, os resultados observados nos permitem defender a tese de que as aulas de Ciências são um espaço de leitura e de escrita, visto que o conhecimento escolar em Ciências é construído através da linguagem escrita. Na busca de ensinar Ciências, processos de ensino-aprendizagem de leitura e de escrita acontecem nas aulas de Ciências. Tais processos são potencializados pelos diálogos estabelecidos pelas professoras com os estudantes e com os textos escritos que circulam nas aulas. As maneiras pelas quais as professoras desenvolvem as diferentes atividades pedagógicas das aulas de Ciências permitem que elementos cotidianos das experiências e vidas dos estudantes interajam com os conhecimentos que estão produzindo nessas aulas, de forma que possam dar sentido aos textos que estão lendo e escrevendo. O potencial do ensino de Ciências para ensino-aprendizagem de leitura aparece na possibilidade de interação com textos de variados gêneros discursivos, na produção textual a partir de interações concretas vivenciadas com os experimentos e na exploração formativa das avaliações elaboradas pelas professoras a partir do que construíram com os estudantes nas aulas. As limitações aos processos de leitura e escrita nas aulas de Ciências são impostas por lacunas na formação docente e, principalmente, por questões estruturais relativas à falta de recursos e ao controle do trabalho das professoras.

Nossa pesquisa, como toda produção de conhecimento científico, abre alguns caminhos para pesquisas futuras. Uma delas se refere à formação docente. Parece-nos que é preciso compreender melhor como questões relacionadas ao ensino-aprendizagem da linguagem escrita aparecem nos currículos da formação em licenciatura em Ciências Biológicas. Aparecem discussões dentro desse tema, 
em que disciplinas, com que perspectivas, e com quais objetivos? Consideramos ainda a necessidade de aprofundamento em pesquisas que reflitam sobre as relações entre letramento científico e outros tipos de letramento, pensando nas interseções entre os variados usos da linguagem que atravessam nossas práticas sociais. Quando refletimos sobre letramento científico no ensino de Ciências, refletimos sobre que concepções de leitura e escrita? Pensamos na relevância de estudos que olhem para dentro da escola e interpretem que letramentos têm ocorrido nesses espaços, quais as possibilidades de interação entre eles e que perspectivas trazem para a aprendizagem escolar. Como o letramento científico se articula com questões mais específicas sobre as habilidades de leitura e de escrita dos estudantes? Nossa investigação aponta ainda para a importância de estudos que analisem as consequências das políticas de controle do trabalho docente (com avaliações externas e bonificações salariais) para o ensino de Ciências e para processos de ensino-aprendizagem de leitura e escrita. Por fim, vemos este trabalho como uma oportunidade para os cursos de formação de professores refletirem sobre o lugar da leitura e escrita no ensino de Ciências e na forma como podem incluir este trabalho nas discussões didáticas.

Enfim, temos muito ainda a construir...

Para finalizar, recuperamos a epígrafe destas considerações finais, que se refere às incertezas de nossos campos de estudo atuais. A contemporaneidade nos coloca nesse lugar da incerteza. Incerteza em como lidar com a crise social e ambiental deste século XXI, incerteza sobre o futuro da humanidade em um mundo que tem aprofundado as desigualdades sociais, incerteza sobre as finalidades de produção de conhecimentos científicos e tecnológicos, incerteza sobre qual o papel da educação e da escola diante dessas questões, incerteza de quais caminhos nos ajudarão a estudar e refletir mais claramente sobre tudo isso. Como poderemos ensinar e aprender a ler e a escrever um mundo diferente? Diante desse quadro, resta-nos uma certeza, a de que há sempre outras possibilidades e é preciso construir esperança, o que só poderemos fazer através de diálogos com o outro. Diálogos estes que as professoras constroem cotidianamente, no compromisso que insistem em assumir com seus estudantes e seus processos de aprendizagem, mesmo diante de todas essas incertezas e de tantas adversidades. 


\section{6 \\ Referências bibliográficas}

ALMEIDA, M. J. P . M.; CASSIANI, S.; e OLIVEIRA, O. B. Leitura e escrita em aulas de Ciências: luz, calor e fotossíntese nas mediações escolares. Florianópolis: Letras Contemporâneas, 2008.

ANDRADE, I. B.; ROCHA, M. A. P. M.; VERMELHO, S. C. e MARTINS, I. Uma análise dos trabalhos apresentados no ENPEC sobre Leitura e Educação em Ciências. In: Anais do X ENPEC, Águas de Lindóia, SP, 2015. Anais digitais.

e MARTINS, I. Discursos de professores de Ciências sobre leitura. Investigações em Ensino de Ciências, v 11, n. 2, p. 121-151, 2006.

BACHELARD, G. A Formação do Espírito Científico: contribuição para uma psicanálise do conhecimento. Rio de Janeiro: Contraponto, 2005.

BAKHTIN, M. Os gêneros do discurso. São Paulo: Editora 34, 2016.

. Estética da criação verbal. $4^{\mathrm{a}}$ ed. São Paulo: Martins Fontes,

2003.

.; VOLOCHÍNOV, V. Marxismo e Filosofia da linguagem. $5^{\text {a }}$ ed. São Paulo: HUCITEC, 1990.

BAUER, A.; ALAVARSE, O. M; e OLIVEIRA, R.P. Avaliações em larga escala: uma sistematização do debate. Educação e Pesquisa. São Paulo, v. 41, n. especial, p. 1367 - 1382, dez. 2015.

BECKER, H. Segredos e truques de pesquisa. Rio de Janeiro: Zahar, 2007.

BONAMINO, A.; ALVES, F.; CRESO, F.; e CAZELLI, S. Os efeitos das diferentes formas de capital no desempenho escolar: um estudo à luz de Bourdieu e de Coleman. Revista Brasileira de Educação, v. 15, n. 45, set./dez. 2010. Pg. 487 - 499.

BRASIL. Ministério da Educação (MEC). Base Nacional Comum Curricular: etapa do ensino fundamental - área de Ciências da Natureza. Ministério da Educação. Brasília: MEC, 2017. Disponível em: $<$ http://basenacionalcomum.mec.gov.br/abase/\#fundamental/a-area-deciencias-da-natureza> Acesso em: 05 de abril de 2018. 
Secretaria de Educação Fundamental. Parâmetros Curriculares Nacionais: ciências naturais. Secretaria de Educação Fundamental Brasília: MEC/SEF, 1997. $136 \mathrm{p}$.

CASSIANI-SOUZA, S., GIRALDI, P. M. e LINSINGEN, I. É possível propor a formação de leitores nas disciplinas de Ciências Naturais? Contribuições da análise de discurso para a educação em ciências. Educação Teoria e Prática, v.22, n.40, 2012.

e ALMEIDA, M. J. P. M. Escrita no ensino de ciências: autores do ensino fundamental. Ciência e Educação, v. 11, n. 3, p. 367-382, 2005.

CASTRO, J. A. Evolução e desigualdade na educação brasileira. Educ. Soc. Campinas, v. 30, n 108, p. 673-697, out-dez 2009.

CAVALLIERI, F. e LOPES, G. P. Índice de Desenvolvimento Social - IDS: comparando as realidades microurbanas da cidade do Rio de Janeiro. Rio de Janeiro: Instituto Municipal de Urbanismo Pereira Passos. 2008 Disponível em: $<$ http://portalgeo.rio.rj.gov.br/estudoscariocas/download/2394_\%C3\%8Dn dice\%20de\%20Desenvolvimento\%20Social_IDS.pdf $\geq$. Acesso em: 06 de setembro de 2017).

CHAVES, M. W. A Escola anisiana dos anos 30: fragmentos de uma experiência - A trajetória pedagógica da Escola Argentina no antigo Distrito Federal (1931-1935). 2001. Tese de doutorado. Faculdade de Educação, PUC-RJ.

CONGRESSO DE LEITURA. Atas do I Seminário sobre Letramento e Alfabetização. In: Anais do 12 COLE (UNICAMP), Campinas, SP, 1999.

COPE, B.; KALANTZIS, M.; e ABD-EL-KHALICK, F. Science in writing: learning scientific argument in principle and practice. E-learningand Digital Media, v.10, n.4, p.420-441, 2013.

COORDENADORIA DE EDUCAÇÃO DO RIO DE JANEIRO. Caderno Pedagógico de Ciências - 6ํano, 3ํo bimestre. Rio de Janeiro: Edigráfica, 2016 a.

COORDENADORIA DE EDUCAÇÃO DO RIO DE JANEIRO. Caderno Pedagógico de Ciências - 6ำ ano, 4ํbimestre. Rio de Janeiro: Edigráfica, 2016 b. 
DANTAS, C. R. S.; MASSONI, N. T.; e SANTOS, F. M. T. A avaliação no Ensino de Ciências Naturais nos documentos oficiais e na literatura acadêmica: uma temática com muitas questões em aberto. Ensaio: avaliação, políticas públicas Educ., Rio de Janeiro. 2017.

DIAS, W. T. Há espaço para a construção autoral nos trabalhos de pesquisa escolar. Tese de doutorado. 2017. Tese (doutorado em educação) - Departamento de Educação, PUC-Rio, Rio de Janeiro.

DIONISIO, A. P. Gêneros multimodais e multiletramento. In: KARXOSKI, A. M.; GAYDECZKA, B.; BRITO, K. S. (Orgs.). Gêneros textuais: reflexão e ensino. 3. ed. Rio de Janeiro: Lucerna, 2008, pg.131-143.

ESTEBAN, M.T. A negação do direito à diferença no cotidiano escolar. Avaliação, Campinas; Sorocaba, SP, v. 19, n. 2, p. 463-486, jul. 2014.

Avaliação e fracasso escolar: questões para debate sobre a democratização da escola. Revista Lusófona de Educação, n. 13, pg. 123-134, 2009.

FARACO, C. A. Autor e autoria. In: BRAIT, B. (org.). Bakhtin: conceitoschave. 4aㅗ ed. São Paulo: Contexto, 2008. Pg. $37-60$.

FERRARO, A. R. A trajetória das taxas de alfabetização no Brasil nas décadas de 1990 e 2000. Educ. Soc., Campinas, v. 32, n. 117, p. 989-1013, out.-dez. 2011.

FERREIRA, M. S.; GOMES, M. M. e LOPES, A. C. Trajetória histórica da disciplina escolar Ciências no Colégio de Aplicação da UFRJ (1949-1968). Pro-Posições, volume 12, n.1 (34), pg. 9 - 26, 2001.

FIORIN, J. L. Da necessidade da distinção entre texto e discurso. In: BRAIT, B. e SOUZA-e-SILVA, M. C. Texto ou discurso? São Paulo: Contexto, 2012. FLICK, U. Introdução à pesquisa qualitativa. 3.ed. Porto Alegre: Artemed, 2009.

FLÔR, C.C. O que dizem os estudos da linguagem na educação científica? Revista Brasileira de Pesquisa em Educação em Ciências, vol. 11, n. 2, 2011. Pg. $67-86$.

FREIRE, P. Pedagogia da autonomia: saberes necessários à prática educativa. São Paulo: Paz e Terra, 1996.

GIORDAN, M. O papel da experimentação no ensino de Ciências. Química Nova na Escola, n. 10, 1999. 
GIRALDI, P. M. Leitura e escrita no ensino de ciências: espaços para produção de autoria. 2010. Tese (doutorado em educação) - Faculdade de Educação, UFSC, Florianópolis.

e CASSIANI, S. Leitura em aulas de ciências: análise de condições de produção. In: Anais do VII ENPEC - em 8 de novembro de 2009, Florianópolis.

GOMES, M.; LOPES, A. C. e SELLES, S. Currículo de Ciências: estabilidade e mudança em livros didáticos. Educação e Pesquisa, 2013, vol.39, n.2, pg.477-492.

GOMES, M. M. Conhecimentos ecológicos em livros didáticos de ciências: aspectos sócio-históricos de sua constituição. 2008. Tese de Doutorado. Universidade Federal Fluminense, Niterói, 2008.

GOODSON, I. F. O currículo em mudança: estudos na construção social do currículo. Cidade do Porto: Porto Editora, 2001.

A construção social do currículo. Lisboa: EDUCA, 1997.

1995.

. Currículo: teoria e história. $2^{\mathrm{a}}$ ed. Petrópolis, RJ: Vozes,

GOULART, C. Uma abordagem bakhtiniana da noção de letramento: contribuições para a pesquisa e para a prática pedagógica. In: FREITAS, M. F.; SOUZA, S. J. e KRAMER, S. (org.) Ciências Humanas e Pesquisa. São Paulo: Cortez. 2003. Pg.95 - 112.

GOWDAK, D. e MARTINS, E. Ciências Novo Pensar: meio ambiente. São Paulo: FTD, 2015.

GRANDI, L. A.; PESSOA DE CARVALHO, A. M.; e MOTOKANE, T. Investigando o discurso de alunos do ensino fundamental durante uma aula de Física. In: VIII ENPEC, 2011. Campinas. Anais digitais. 12 p.

GUIMARÃES, C. Educação pública, lógica privada. Parcerias com instituições privadas pautam projetos da escola pública e criam nichos de mercado para empresas. Revista Poli, ano V, n.27, mar/ abr 2013.

INEP. IDEB - $\quad$ Apresentação. Disponível em: $<$ http://portal.mec.gov.br/secretaria-de-educacao-basica/programas-eacoes? id=180> Acesso em: 28 de agosto de 2017. 
PISA. 2017 a. Disponível em: <http://portal.inep.gov.br/web/guest/pisa>. Acesso em: 06 de setembro de 2017.

. SAEB. 2017 b Disponível em: <http://portal.inep.gov.br/educacaobasica/saeb>. Acesso em: 06 de setembro de 2017.

. Brasil no PISA 2015: análise e reflexões sobre o desempenho dos estudantes brasileiros/ OCDE: Organização para a Cooperação e Desenvolvimento Econômico - São Paulo: Fundação Santillana, 2016 a.

Disponível em: <http://inep.gov.br/artigo//asset_publisher/B4AQV9zFY7Bv/content/inep-apresenta-resultados-dosaeb-prova-brasil-2015/21206> Acesso em: 06 de setembro de 2017.

KINCHLOE, J. L. Introdução. In: GOODSON, I. F. O currículo em mudança: estudos na construção social do currículo. Cidade do Porto: Porto Editora, 2001. Pg. $7-29$.

KOCK, I. G. V. Desvendando os segredos do texto. São Paulo: Cortez, 2003.

e ELIAS, V. M. Ler e escrever: estratégias de produção textual. $2^{\mathrm{a}}$ ed. São Paulo: Contexto, 2017.

e ELIAS, V. M. Ler e compreender: os sentidos do texto. $3^{a}$ ed. São Paulo: Contexto, 2015.

KONDER, L. O Paradoxo da linguagem. Jornal O Globo. 29/03/1997, pg. 7.

KRASILCHIK, M. e MARANDINO, M. Ensino de ciências e cidadania. São Paulo: Moderna, p. 147-163, 2004.

KUHN, D., Science as Argument: Implications for Teaching and Learning Scientific Thinking. Science Education, v. 77, n. 3, p. 319 - 337, 1993.

LAGE, M. C. Os softwares tipo CAQDAS e a sua contribuição para a pesquisa qualitativa em educação. Educação Temática Digital, v. 12, n. 2, p. 42-58, 2011. 
LAHIRE, B. Trajetória acadêmica e pensamento sociológico: entrevista com Bernard Lahire. Educação e Pesquisa, São Paulo, vol. 30, n.2, p.315321. Maio/agosto 2004.

LEAL, C. A.; QUIRINO, M. J. S. O.; FARUOLO, T. C. L. M.; OLIVEIRA, V. L.; MARQUES, C. S. e ANJOS, M. B. Práticas Pedagógicas e Metodologias Empregadas na Docência em Ensino de Ciências. In: VII ENPEC, 2009. Belo Horizonte. Anais digitais.

LEAL, L. F. V. A formação do produtor de texto escrito na escola: uma análise das relações entre os processos interlocutivos e os processos de ensino. In: VAL, M. G. C. e ROCHA, G. (org.) Reflexões sobre práticas escolares de produção de texto - o sujeito-autor. Belo Horizonte: Autêntica, 2008. p. $53-68$.

LIVINGSTONE, S. Internet literacy: a negociação dos jovens com as novas oportunidades on-line. Matrizes. São Paulo, ano 4, n 2, p. 11-42, jan.- jun. 2011.

LOPES, A. C. e MACEDO, B. Teorias de currículo. São Paulo: Cortez Editora, 2011.

LOPES, A. C. Currículo de Ciências do Colégio de Aplicação da UFRJ (1969-1998): um estudo sócio-histórico. Revista Teias, volume 1, n. 2, 17 pgs., 2007.

- Conhecimento Escolar em Química - Processo de Mediação Didática da Ciência. Química Nova na Escola. V. 20, n. 5, 1997, p. 563-568.

LOPES, C. V. M.; e DULAC, E. B. F. Ideias e palavras na/da ciência ou leitura e escrita: o que a ciência tem a ver com isso? In: NEVES, I. C. B. et.al. (Orgs). Ler e escrever: compromisso de todas as áreas. 11 ed. Porto Alegre: Editora da UFRGS, 2011.

LUDKE, M. e ANDRÉ, M. E. D. A. Pesquisa em educação: abordagens qualitativas. São Paulo: EPU, 1986.

LUZ, R. P. O uso do caderno pedagógico de ciências em sala de aula no ensino fundamental da Secretaria Municipal de Educação do Rio de Janeiro: desafios e tensões, 2016. Dissertação (mestrado em educação) Departamento de Educação, PUC-Rio, Rio de Janeiro.

MACEDO, E. F. e LOPES, A.C. (orgs). Disciplinas de Integração Curricular: história e políticas. Rio de Janeiro: DPeA, 2002. pg. 73-114. 
MAGALHÃES DE LIMA, M. F. Governança, accountability e qualidade: confluência e emergência nas políticas educacionais. In: IV Congresso Ibero-Americano de Política e Administração da Educação / VII Congresso Luso Brasileiro de Política e Administração da Educação (ANPAE), 2014. Cidade do Porto. Anais digitais. $16 \mathrm{p}$.

MATOS, M.; VILELA, M.; e MACIEL, C. . Formando alunos leitores no diálogo entre universidade e escola: a experiência da Ciranda de Leitura de Ciências. Cadernos do Aplicação (UFRGS), v. 22, p. 203-214, 2009.

MARANDINO, M. Experimentação no Ensino de Ciências e Biologia: Metodologia do Ensino de Ciências Biológicas I. Disponível em: $<$ http://edisciplinas.usp.br/ apresentação\%203\%20Experimentação\%20no\%20Ensino\%20de\%20Ciê ncias\%20(5).pdf > Acesso em: 05 de abril de 2018.

; SELLES, S. E.; e FERREIRA, M. S. A experimentação científica e o ensino experimental em Ciências e Biologia. In: MARANDINO, M.; SELLES, S. E.; e FERREIRA, M. S. (org.). Ensino de Biologia: histórias e práticas em diferentes espaços educativos. São Paulo: Cortez, 2009. Pg. $95-116$.

MARCUSCHI, L. Produção Textual, análise de gêneros e compreensão. São Paulo: Parábola Editorial, 2008.

A. Gêneros textuais: definição e funcionalidade. In: DIONISIO, A. P.; MACHADO, A. R.; BEZERRA, M. A. (Org.). Gêneros textuais e Ensino. Rio de Janeiro: Editora Lucerna,2003. p. 19-36.

MARCUZZO, P. Diálogo inconcluso: os conceitos de dialogismo e polifonia na obra de Mikhail Bakhtin. Cadernos do IL. Porto Alegre, n. 36, 2008, p. 2 -10 .

MARTINS, I.; GOUVÊA, G.; PICCININI, C.; BUENO, T; LENTO, C.; PEDRO, T. e PAULO, N. Uma análise das imagens nos livros didáticos de ciências para o ensino fundamental. In: Anais do IV ENPEC, Bauru, SP, 2003. Anais digitais.

MOREIRA, A. F. B. Propostas curriculares alternativas: limites e avanços. Educação e Sociedade, volume 21, n. 73, pg. 109-138, 2000.

MORTIMER, E. F.; CHAGAS, A. N.; e ALVARENGA, V. T. Linguagem científica versus linguagem comum nas respostas escritas de vestibulandos. Investigações em Ensino de Ciências, vol. 3, n. 1, 1998. Pg. $7-19$. 
NOGUEIRA, C. M. M. A abordagem de Bernard Lahire e suas contribuições para a sociologia da educação. In: Anais da $36^{\underline{a}}$ Reunião Nacional da ANPEd, Goiânia, 2013.

OLIVEIRA, I. A.; FONSECA, M. J. e SANTOS, T. A entrevista na pesquisa educacional. In: MARCONDES, M. I.; OLIVEIRA, I. e TEIXEIRA, E. (Org). Metodologias e técnicas de pesquisa em educação. Belém: EDUEPA, 2010.

OLIVEIRA, J. R. S. de. Contribuições e abordagens das atividades experimentais no ensino de ciências: reunindo elementos para a prática docente. Acta Scientiae v. 12, n.1, p.139-153 jan./jun. 2010.

PENNA, F. de A. Entrevista com Fernando de Araújo Penna: "Escola sem partido" - série "Conquistas em risco": depoimento. (20 de Abril, 2016). Rio de Janeiro: ANPED. (Disponível em: $<$ http://www.anped.org.br/news/entrevista-com-fernando-de-araujo-pennaescola-sem-partido-serie-conquistas-em-risco $>$. Acesso em: 13 de julho de 2016).

PHILIPS, D. C. e BURBULES, N. Can, and should, educational inquiry be scientific? In: PHILIPS, D. C. e BURBULES, N. (org.) Postpositivism and Educational Research. Oxford: Rowman and Littlefield Publishers, 2000. pg. $65-95$.

PINHEIRO, D. L. e GALIETA, T. Produções textuais sobre o ciclo da água: a autoria como prática de letramento científico. Revista SBENBio, n. 9, 2016.

PINHEIRO, F. B. Estratégias de leitura para os gêneros textuais mapa, tabela e artigo de divulgação científica: contribuições para o ensino de ciências. 2015. 133 p. Dissertação (Mestrado Profissional em Ensino de Ciência e Tecnologia) - Programa de Pós-Graduação em Ensino de Ciência e Tecnologia. Universidade Tecnológica Federal do Paraná, Paraná.

RODRIGUES, E. S, e RIBEIRO, A. J. C. Lendo pizzas: dados de eyetracking sobre informação top-down na análise de gráficos de setores. In: anais do $X$ Congresso Internacional da ABRALIN, Niterói, RJ, UFF, 2017. Anais digitais.

ROJO, R. Gêneros do discurso e gêneros textuais: questões teóricas e aplicadas. In: Gêneros: teorias, métodos, debates. MEURER, J. L.; BONINI, A.; MOTTA-ROTH, D.(org.). São Paulo: Parábola, 2005. p. 184-207. 
ROLDÃO, M. C. Produção e uso do conhecimento: tensões e desafios na investigação educacional. In: SOUZA, F. N.; SOUZA, D. N. e COSTA, A. P. (org.) Investigação Qualitativa- inovações, dilemas e desafios. Aracaju: EDUNIT, 2015. pg.15 - 40.

ROSITO, B. A. O ensino de Ciências e a experimentação. In Construtivismo $e$ ensino de Ciências: reflexões epistemológicas e metodológicas. MORAES, R. (org.). $3^{a}$ edição. Porto Alegre: edi PUCRS, 2008.

SALOMÃO, S. Lições da Botânica: um ensaio para as aulas de Ciências. 2005. Tese de doutorado - Programa de Pós-Graduação em Educação. Universidade Federal Fluminense, Niterói.

SANTOS, T. Do artesanato intelectual ao contexto virtual: ferramentas metodológicas para a pesquisa social. Sociologias, Porto Alegre, ano 11, $n^{\circ} 21$,. p. $120-156$. jan./jun. 2009.

SANTOS, W.; MORTIMER, E. e SCOTT, P. A argumentação em discussões sócio-científicas: reflexões a partir de um estudo de caso. Revista Brasileira de Pesquisa em Educação em Ciências, América do Norte, v. 1, nov. 2011.

SCHNEIDER, M. P. Entrevista com o professor Almerindo Janela Afonso: dialogando sobre políticas de regulação e avaliação no campo da educação. Roteiro, v. 37, n. 2, p. 185-90, jul./dez. 2012.

SECRETARIA MUNICIPAL DE EDUCAÇÃO, ESPORTES E LAZER DO RIO DE JANEIRO. Educação em números. 2017 a. (Disponível em: http://www.rio.rj.gov.br/web/sme/educacao-em-numeros. Acesso em 06 de setembro de 2017)

- Escolas do Amanhã. 2017 b. (Disponível em: http://www.escolasdoamanha.com.br/. Acesso em 06 de setembro de 2017)

SELLES, S. E.; e FERREIRA, M.S. Disciplina escolar biologia: entre a retórica unificadora e as questões sociais. In: MARANDINO, M.; SELLES, S.E.; FERREIRA, M.S.; e AMORIM, A.C.R. (org.) Ensino de Biologia: conhecimentos, valores e disputas. Niterói: Eduff, 2005. p.50-61.

SILVA, E. T. Concepções de leitura e suas consequencias no ensino. Perspectiva - Florianópolis, v.17, n. 31, p. 11 - 19, jan./jun. 1999.

. Ciência, leitura e escola.In: ALMEIDA, M. J. P. M. e CESAR, $\mathrm{H}$. (orgs.). Linguagem, leituras e ensino de ciências. Campinas: Mercado de Letras - ALB, p. 121 - 130. 1998. 
SOARES, A. D. e COUTINHO, F. A. Leitura, discussão e produção de textos como recurso didático para o ensino de biologia. Revista Brasileira de Pesquisa em Educação em Ciências, São Paulo, v. 9, n. 2, 2009.

SOARES, M. Magda Soares responde. Centro de alfabetização, lei tura e escrita - Ceale/ FaE/ UFG. parte 5, 2015. (Disponível em: $<$ http://www.ceale.fae.ufmg.br/pages/view/magda-soares-responde4.html> Acesso em: 14 de maio de 2018)

- Alfabetização e cidadania. In SOARES, M. (org.) Alfabetização e letramento. 5. ed. São Paulo: Contexto, p. 55 - 60. 2007.

Letramento: um tema em três gêneros. Belo Horizonte: Autêntica, 1998.

SOBRAL, A. A concepção de autoria do "Círculo Bakhtin, Medvedev, Voloshinov": confrontos e definições. Macabéa - Revista Eletrônica do Netlli, vol. 1, n.2, 2012. Pg. 123 - 142.

SOUZA, G. S. M.; SILVA, E. S.; SANTOS, K. N.; e SANTOS, B. F. A pesquisa sobre linguagem e ensino de ciências no Brasil em teses e dissertações (2000-2011). In: Anais do IX ENPEC, 2013, Águas de Lindóia, SP. Anais digitais.

SOUZA, S. C. Leitura e fotossíntese: Proposta de Ensino numa abordagem cultural. Tese de Doutorado em Educação. Faculdade de Educação: Universidade Estadual de Campinas, 2000.

SUISSO, C. e GALIETA, T. Relações entre leitura, escrita e alfabetização/letramento científico: um levantamento bibliográfico em periódicos nacionais da área de ensino de ciências. Ciência e Educação, Bauru, v.21, n.4, p. 991-1009, 2015.

SUTTON, C. Los profesores de ciencias como professores de lenguaje. Enseñanza de las Ciencias, v. 21, n. 1. p. 21-25, 2003.

SCHNEUWLY, B. Gêneros e tipos de discurso: considerações psicológicas e ontogenéticas. In: SCHNEUWLY, B. e DOLZ, J. (org.). Gêneros orais e escritos na escola. Campinas: Mercado das Letras. 2004.

VENEU, A.; FERRAZ, G. e REZENDE, F. Análise de discursos no ensino de ciências: considerações teóricas, implicações epistemológicas e metodológicas. Revista Ensaio. Belo Horizonte, V. 17, n. 1, jan-abr 2015, p. 126-149. 
VILELA, M. VASCONCELLOS, D. V.; e GOMES, M. M. Reflexões sobre abordagens didáticas na interpretação de experimentos no ensino de Ciências. Revista da SBEnBIO, n. 01. Agosto de 2007, pg. 8 - 10.

YAMADA, M.; e MOTOKANE, M. T. Alfabetização científica: apropriações discursivas no desenvolvimento da escrita de alunos em aula de ecologia. Revista Práxis, Volta Redonda, v. 5, n. 10, p. 29-40, 2013. 


\title{
Apêndice 1 - Termos de consentimento das professoras, responsáveis dos alunos e de assentimento dos alunos
}

\author{
TERMO DE CONSENTIMENTO LIVRE E ESCLARECIDO PARA PROFESSORES
}

PROJETO:LER E ESCREVER NAS AULAS DE CIÊNCIAS: POTENCIALIDADES E

LIMITES

PESQUISADOR RESPONSÁVEL: MARIA CORDEIRO DE FARIAS GOUVEIA MATOS

(emaildamariamatos@yahoo.com.br/tel: 983367743)

ORIENTADORA DA PESQUISA: PROFㅁRㅡ ZENA EISENBERG (zwe@puc-rio.br/tel:

3527-1818 ramal 111)

Buscaremos, através desta pesquisa, entender como atividades pedagógicas das aulas de Ciências podem contribuir na formação de alunos leitores e escritores. Essa investigação visa compreender especificidades das aulas de Ciências que contribuem no entendimento e na produção da linguagem escrita. Estuda de que forma textos lidos e produzidos nas aulas de Ciências são trabalhados pelos professores e alunos. Analisa ainda a concepção de professores de Ciências, de alunos e de materiais pedagógicos sobre os processos de leitura e escrita que ocorrem nas aulas de Ciências. O projeto abarcará professores e alunos de turmas do sexto ano de escolas públicas municipais do Rio de Janeiro. A pesquisa envolverá os seguintes processos de coleta de dados: a) entrevistas (com professores de Ciências e alunos das escolas estudadas) b) observação de aulas de Ciências (de diferentes turmas de sexto ano do ensino fundamental) c) análise de materiais pedagógicos e mecanismos avaliativos. Após a coleta, os dados serão analisados e a tese será redigida, relatando os resultados obtidos. Não antecipamos qualquer risco moral ou físico aos participantes da pesquisa, uma vez que as entrevistas e as observações serão direcionadas para o entendimento das realidades vividas pelos participantes em sua vida cotidiana e suas identidades serão mantidas em sigilo. Ao fim da pesquisa, o texto final poderá ser acessado por todos os entrevistados e observados, para que os mesmos tenham um retorno da colaboração dada neste processo investigativo.

\footnotetext{
Maria Cordeiro de Farias Gouveia Matos Doutoranda em Educação Brasileira Programa de Pós-Graduação em Educação Departamento de Educação - PUC-Rio
} 
Pelo presente documento declaro ter conhecimento dos objetivos e da metodologia que será adotada no estudo conduzido pela doutoranda Maria Cordeiro de Farias Gouveia Matos (emaildamariamatos@yahoo.com.br/ tel: 983367743), sob a orientação da Profạna Zena Eisenberg (zwe@puc-rio.br/ tel: 3527-1818 ramal 111) do Programa de Pós-Graduação do Departamento de Educação da PUC-Rio.

Estou informado(a) de que se houver qualquer dúvida a respeito dos procedimentos que serão utilizados obterei explicações assim como terei total liberdade para me retirar desta pesquisa, se e quando assim julgar conveniente, não sofrendo nenhuma penalização ou constrangimento por essa decisão.

Meu consentimento está fundamentado na garantia de que serei respeitado(a) em todos os sentidos, com destaque para os seguintes aspectos:

a) Meu nome não será divulgado; todas as informações individuais têm caráter confidencial; a apresentação de resultados em congressos e artigos científicos utilizará os dados de grupos e codinomes, de modo a não permitir a identificação individual dos participantes.

b) A eventual tomada de audiogravação é parte do processo de registros e ocorrerá com meu consentimento, não sendo permitida sua divulgação pública, com exceção da utilização em contextos estritamente acadêmicos;

c) Todas as entrevistas ocorrerão em datas e horários sugeridos por mim, de modo que minha rotina não seja prejudicada;

d) Serei informado(a) das datas e horários de todas as observações de aulas (quando ocorrerem);

e) A pesquisadora está obrigada a prestar esclarecimentos sobre o processo de pesquisa, os fins atribuídos às entrevistas e observações a qualquer momento e sobre os resultados produzidos, na ocasião do término da pesquisa;

O termo será assinado em duas vias: uma para a pesquisadora e outra para o(a) participante.

Autorizo abaixo minha participação neste estudo.

Rio de Janeiro, de de 2016. 
TERMO DE CONSENTIMENTO LIVRE E ESCLARECIDO PARA RESPONSÁVEIS PROJETO:LER E ESCREVER NAS AULAS DE CIÊNCIAS: POTENCIALIDADES E LIMITES

PESQUISADOR RESPONSÁVEL: MARIA CORDEIRO DE FARIAS GOUVEIA MATOS

(emaildamariamatos@yahoo.com.br/tel: 983367743)

ORIENTADORA DA PESQUISA: PROFㅁRㅡ ZENA EISENBERG (zwe@puc-rio.br/tel:

3527-1818 ramal 111)

Seu(sua) filho(a) está sendo convidado(a) a participar de uma pesquisa que será realizada em sua escola. Com esta pesquisa queremos entender como atividades das aulas de Ciências podem contribuir na formação de alunos leitores e escritores. Estudaremos de que forma textos lidos e produzidos nas aulas de Ciências são trabalhados pelos professores e alunos. Analisaremos também o entendimento dos professores de Ciências, de alunos e de materiais pedagógicos sobre os processos de leitura e escrita que ocorrem nas aulas de Ciências. O projeto envolverá professores e alunos de turmas do sexto ano de escolas públicas municipais do Rio de Janeiro. A pesquisa apresentará os seguintes processos de coleta de dados: a) entrevistas (com professores de Ciências e alunos das escolas estudadas) b) observação de aulas de Ciências (de diferentes turmas de sexto ano do ensino fundamental) c) análise de materiais pedagógicos e mecanismos avaliativos. Gostaríamos que seu(sua) filho(a) participasse das entrevistas, além das aulas observadas. Destacamos que:

a) Não existem riscos ou desconfortos previstos na participação de seu(sua) filho(a). A participação não acarretará nenhum preconceito, discriminação ou desigualdade social.

b) Os resultados deste estudo podem ser publicados, mas o nome ou identificação de seu(sua) filho(a) não serão revelados.

c) Não haverá remuneração ou ajuda de custo (ressarcimento) pela participação

d) A pesquisadora está obrigada a prestar esclarecimentos sobre o processo de pesquisa, os fins atribuídos às entrevistas e observações a qualquer momento e sobre os resultados produzidos, na ocasião do término da pesquisa;

O termo será assinado em duas vias: uma para a pesquisadora e outra para o(a) participante. Afirmo que recebi explicações sobre a natureza, riscos e benefícios do projeto. Ao assinar, assumo a participação de meu(minha) filho(a) e compreendo que posso retirar meu consentimento e interrompê-lo a qualquer momento, sem penalidade ou perda de benefício.

Rio de Janeiro, de de 2016. 


\section{TERMO DE ASSENTIMENTO DOS ESTUDANTES}

PROJETO: LER E ESCREVER NAS AULAS DE CIÊNCIAS: POTENCIALIDADES E LIMITES

PESQUISADOR RESPONSÁVEL: MARIA CORDEIRO DE FARIAS GOUVEIA MATOS (emaildamariamatos@yahoo.com.br/ tel: 983367743)

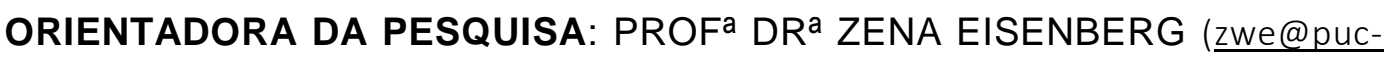
rio.br/ tel: 3527-1818 ramal 111)

Você está sendo convidado para participar da pesquisa $L E R E$ ESCREVER NAS AULAS DE CIÊNCIAS: POTENCIALIDADES E LIMITES. Seus pais permitiram que você participe. Queremos saber como as aulas de Ciências podem ensinar as crianças a lerem e escreverem melhor. As crianças que irão participar dessa pesquisa são estudantes do sexto ano do ensino fundamental. Você não precisa participar da pesquisa se não quiser, é um direito seu, não terá nenhum problema se desistir. A pesquisa será feita nas aulas de Ciências da sua turma e a pesquisadora ficará observando como as aulas acontecem e entrevistará alguns alunos. Ninguém saberá que você está participando da pesquisa, não falaremos a outras pessoas, nem daremos a estranhos as informações que você nos der. Os resultados da pesquisa vão ser publicados, mas sem identificar as crianças que participaram da pesquisa. Quando terminarmos a pesquisa viremos na escola explicar o que conseguimos descobrir. Achamos que a pesquisa poderá nos ajudar a construir uma escola melhor, na qual as crianças aprendam cada vez mais. Se você tiver alguma dúvida, você pode me perguntar, me escrever um e-mail ou telefonar. Eu escrevi os telefones e meu email na parte de cima desse texto.

$\mathrm{Eu}$ aceito participar da pesquisa LER E ESCREVER NAS AULAS DE CIÊNCIAS: POTENCIALIDADES E LIMITES, que tem o objetivo de estudar as relações entre as aulas de Ciências e a leitura e escrita dos estudantes. Entendi como a pesquisa vai acontecer. Entendi que posso dizer "sim" e participar, mas que, a qualquer momento, posso dizer "não", sem nenhum problema. A pesquisadora tirou minhas dúvidas e conversou com os meus responsáveis. Recebi uma cópia deste termo de assentimento e li e concordo em participar da pesquisa.

Rio de Janeiro, de de

\section{Estudante}




\section{Apêndice 2 - Roteiro de entrevista das professoras}

1) Conte-me um pouco da sua trajetória profissional. Há quanto tempo você é professora de Ciências? Já trabalhou em outras escolas?

2) Me fale um pouco da sua formação.

3) Que importância você vê na leitura e na escrita para a formação de seus alunos? Por que?

4) Você realiza alguma das seguintes atividades com seus alunos nas aulas de ciências?

a. Ler em voz alta. Nunca, às vezes ou sempre?

b. Leitura coletiva em silêncio. Nunca, às vezes ou sempre?

c. Aferimento da compreensão do texto. Nunca, às vezes ou sempre?

d. Esclarecimento de dúvidas na compreensão dos textos trabalhados. Nunca, às vezes ou sempre?

e. Correção da escrita deles nos exercícios e nas provas. Nunca, às vezes ou sempre?

f. Escrita de texto coletivo. Nunca, às vezes ou sempre?

g. Interpretação e discussão de situações científicas de forma escrita. Nunca, às vezes ou sempre?

5) Imagine que você é professora do $7^{\circ}$ ano. Chega um aluno com muitas dificuldades de leitura e escrita. Ele não consegue interpretar textos e nem escrever bem. O que você pensa sobre isso? Como você iria lidar com essa situação? O que você faria?

6) O que você acha do professor de ciências trabalhar a leitura e a escrita nas suas aulas? Explique os aspectos que você vê como positivos e os que vê como negativos.

7) Que dificuldades você vê seus alunos terem com relação à leitura e à escrita? Como percebe essas dificuldades (por que aparecem)?

8) Quais dificuldades você acha que textos de ciências apresentam para os alunos?

9) Que tipos de textos você costuma trabalhar em aula?

10) Quais atividades nas suas aulas envolvem a escrita por parte dos alunos?

11) Em que momentos do processo pedagógico as dificuldades com leitura e escrita aparecem mais (provas, aulas experimentais, exercícios)? 
12) Na sua opinião, quais os maiores obstáculos para o trabalho com leitura e escrita nas aulas de Ciências? 


\section{Apêndice 3 - Roteiro de entrevista dos estudantes}

1) Você gosta das aulas de Ciências? Por quê?

2) Qual matéria você mais gosta na escola? Por quê?

3) Você tem muita leitura para fazer na aula de Ciências? Os textos são compridos? Mais ou menos que em outras matérias? Quais?

4) Vocês trabalham com um livro de ciências? Você acha difícil ler os textos nele? Vocês só leem em sala ou tem que ler em casa também? Alguém te ajuda? Quem?

5) Você se lembra de algum texto que você tenha lido esse ano nas aulas de Ciências? Você gostou? Ele era sobre o que?

6) E escrever? Você escreve muito nas aulas de Ciências? Você se lembra de alguma coisa que tenha escrito? Alguma atividade que você teve que escrever alguma coisa... Era sobre o quê? O texto que você escreveu foi de mais ou menos quantas linhas? Você achou muito comprido? Achou difícil ou fácil?

7) Você acha Ciências fácil ou difícil? Por quê?

8) Aprender a ler e escrever, você acha importante? Por quê?

9) Você acha que já aprendeu a ler e escrever o suficiente? Ou precisa aprender mais?

10) Você acha que aprende a ler e escrever melhor nas aulas de Ciências? O que vocês fazem que te ajuda a aprender a ler e a escrever? 